
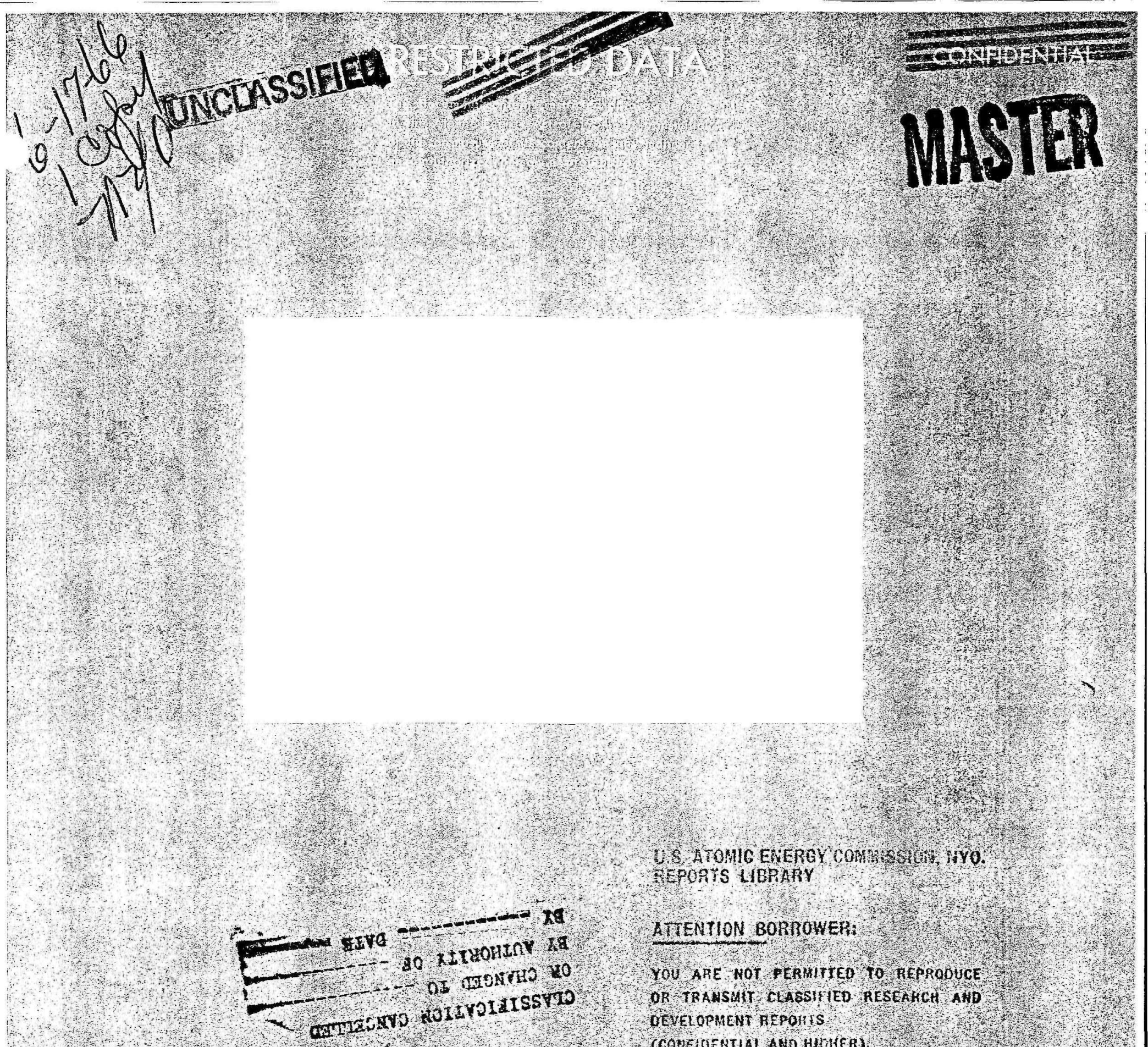

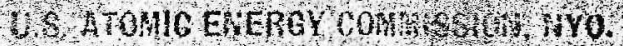
EEROATS LIBPARY

\title{
ATIENTION BORROWER:
}

YOU ARE NOT FERMITTEO TO REPRADUCE OR TRAMSUIT CLAESIFIED RESEARCH AHD OEVELOPMENT HEPOHIS (COMEDEATHA ANO HEHEn). Where such rerons 10 Who krronts Lish a H ro

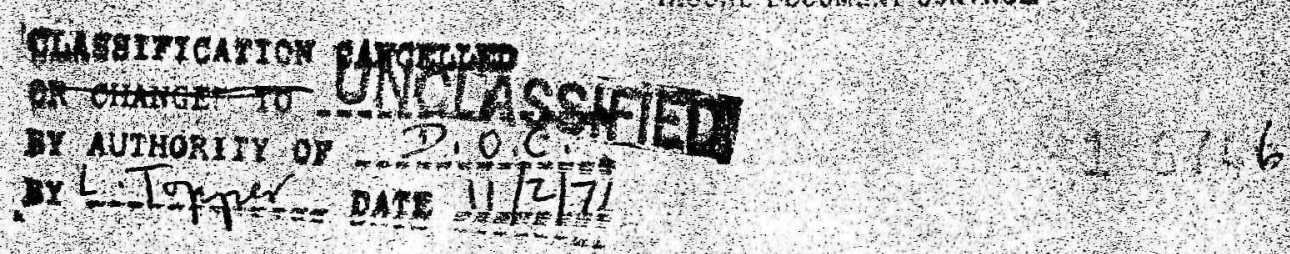




\section{DISCLAIMER}

This report was prepared as an account of work sponsored by an agency of the United States Government. Neither the United States Government nor any agency Thereof, nor any of their employees, makes any warranty, express or implied, or assumes any legal liability or responsibility for the accuracy, completeness, or usefulness of any information, apparatus, product, or process disclosed, or represents that its use would not infringe privately owned rights. Reference herein to any specific commercial product, process, or service by trade name, trademark, manufacturer, or otherwise does not necessarily constitute or imply its endorsement, recommendation, or favoring by the United States Government or any agency thereof. The views and opinions of authors expressed herein do not necessarily state or reflect those of the United States Government or any agency thereof. 


\section{DISCLAIMER}

Portions of this document may be illegible in electronic image products. Images are produced from the best available original document. 


\title{
MUom
}

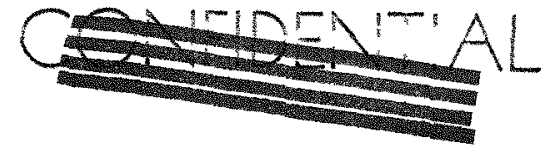

NOTICE

This report was prepared as an account of work sponsored by the United States Government. Netther the United States nor the United States Atomic Energy Commission, nor any of therr employees, nor any of their contractors, subcontractors, or their employees, makes any warranty, express or implied, or assumes any legal liabiluty or responsibality for the accuracy, com. pleteness or usefulness of any information, apparatus, product or process disclosed, or represents that its use would not infringe privately owned rights.

RDD-2 PIOGRAN

\section{SULMARY GRAOTD TEST}

\author{
ETPOTM \\ $\therefore-5-3283-?$
}

I. J. Dobry, Projes Angineen, $\quad-m-2$

V.A. Elextri, -uclear Salety

I. T. Harmison, Wuclear Sarety
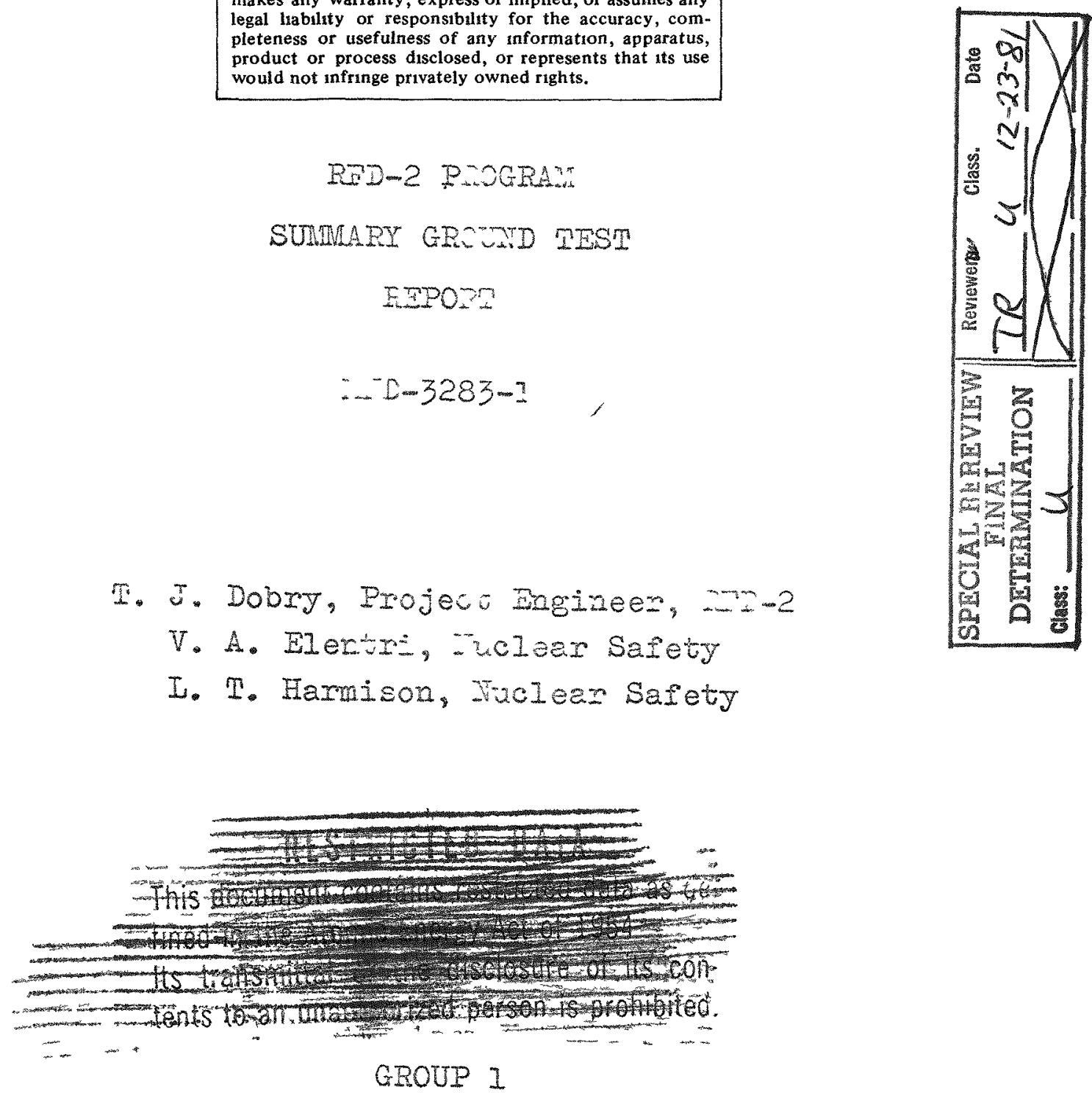

Excluded from automatic

downgraing and declassification

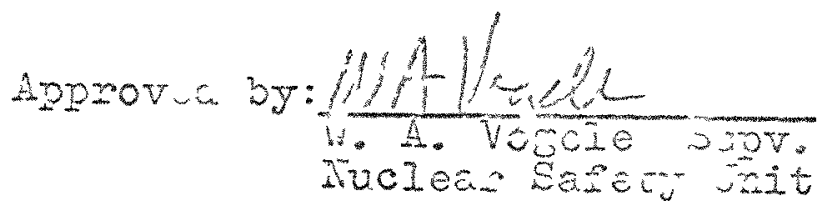

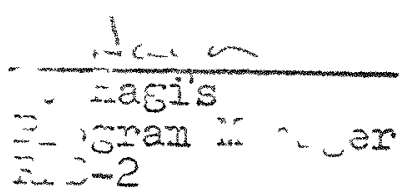

UNCLASSIFIED 


\section{DISPE- = - =}

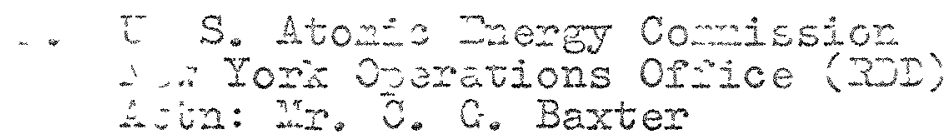

$2 \operatorname{cop} i=5$

- I. S. Atomic Energy Connistion (Hg) (DRD) 18 oopiew Tr. sington $D$. $O$

Autr: Lt. Col. H. K. In m 
This report is a data summary evaluation of all safety tests conducted by the Martin Company for the RFD-2 Program. It was prepared in compliance with The U. S. Atomic Energy Commission Contracts AT(30-1)3283, AT (30-1)-3169, and Statement of Work MN-SW-1175 "Support of a Flight Test program on Radioisotope Fueled, Space Power Systems (Re-entry Flight Device-2)" dated August 28, 1963. 


\section{ACKNOWIEDGMENTS}

Acknowledgment is given to the following personnel for their contribution to this report: Doctors'

D. Evans and W. McNerney of The Materials Research and Development Laboratories, G. Schmidt of The Plasma Arc Test Facility, S. Gottlieb and A. Flescher of The Wind Tunnel Analysis and Test Group and Lowelle Harmison of Nuclear Safety. 
TABIE OF CONTENTS

Page

FOREWORD.

ACKNOWLEDGMENT

CONTENTS.

I. INTRODUCTION................. I-I

II. HIGH TEMPERATURE MATERIAIS COMPATIBILITY

TESTS ................... II-1

A. Test Procedures and Equipment . . . . II-1

B. Test Data, Results and Conclusions. . II-2

III. PLASMA ARC TEST . . . . . . . . . . III-I

A. Plasma Arc Re-entry Simulation. ... III-3

B. Test Parameters and Procedures. . . , III-12

C. Test Specimens......... III-17

1. Tantalum Oxidation Model. . . . III-I7

2. Tantalum Fuel Liners. . . . . III-17

3. Fuel Capsule Assembly . . . . III-17

4. Simulated Generator Specimens . . III-22

D. Test Data and Results ....... III-30

1. Plasma Arc Data ....... III-30

2. Specimen Instrumentation Data. . III-30

3. Specimen Analysis ... . . . . III-33

4. Summary of Results. . . . . . III-I27

E. Conclusions.......... III-129

IV. WIND TUNNEI TEST. . . . . . . . . . . . IV-1

A. Test Facility ............. IV-I

B. Test Specimens and Procedures . . . . IV-2

C. Data and Results. . . . . . . . IV-7

D. Data Interpretation....... IV-9

E. Conclusions . . . . . . . IV-14

V. REFERENCES. ............. V-1 


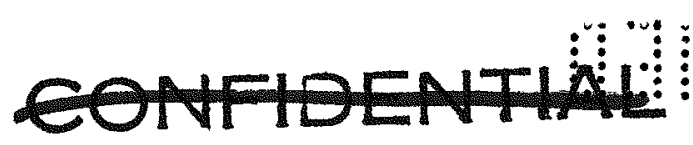

\section{INTRODUCTION}

This report summarizes parameters, data, results, and conclusions of an experimental ground test program designed to demonstrate the characteristic behavior of space power system materials and components when exposed to a re-entry environment. Specifically, the conclusions will be used to predict and evaluate the expected performance of the Re-entry Flight Device -2 (RFD-2) experiment and the safety aspects of future space power systems.

The program consisted of a high temperature materials compatibility test, two series of plasma jet tests, and a wind tunnel test. Materials compatibility tests were run to determine the static reaction rate of Haynes Alloy No. 25 with graphite when protected by various metal foil materials at elevated temperatures. Plasma jet tests were conducted to investigate, under simulated dynamic re-entry conditions, the behavior of tantalum, the burn-up characteristics of Haynes-25, the ablation rates of generator housing and insulation materials (magnesium and $M i n-K$ ), and the reaction rates of molten Haynes-25 with heat accumulator block materials (graphite and boron nitride). Finally, wind tunnel tests were run to expose the heat accumulator and fuel capsule assembly to an equivalent environment of Mach 20 at an altitude of 200,000 feet. The objectives of this test were to measure separating moments and record on film the disassembly of the component parts. 


\section{HIGH TEMPERATURE MATERTALS COMPATIBILITY TEST}

When a space nuclear power system re-enters into the earth's atmosphere, materials that make up the system heat up and melt at different times. The molten mass of a low melting material could react with materials of higher melting points preventing the desire disassembly of the structure. To impede such a condition, studies were made and experiments were conducted to determine if metal foils could be used between the various materials. The high temperature materials compatibility test was designed to select the best foil material which could be used around Haynes-25 material to prevent chemical reactions with graphite. Haynes-25 and graphite were particularized because they are currently being considered as fuel capsule and heat accumulator block materials in many isotopic fueled space power systems. A specific purpose of the test was to establish the degree of reaction of the two materials separated by various foils at elevated temperatures. Also during this program, tests were conducted to evaluate various ceramic materials which might be used as a substitute for the graphite heat accumulator block.

The following discusses the procedures and equipment used for the tests, outlines the data accumulated, and presents the results and conclusions derived from the test.

\section{A. TEST PROCEDURES AND EQUIPMENT}

Five different metal foils were tested in combination with Haynes-25 and graphite. These were; titanium, zirconium, tantalum, tungsten and columbium. Each foil, one and a half inches in diameter, was placed between a two 
inch diameter, one half inch long cylinder of graphite and a one inch square 0.064 inch thick specimen of Haynes-25. This assembly was then placed in a high temperature resistance heater type furnace and heated for 15 minutes at a temperature above the melting point of Haynes-25, $2425^{\circ} \mathrm{F}$. Each run was repeated twice, once in air and once in a hydrogen atmosphere. The hydrogen atmosphere was used in the second run to eliminate high temperature oxidation effects of the graphite.

Tests to find a substitute for graphite were made on seven different ceramic materials. These were; $\mathrm{ZrB}_{2}$ ' borolite ( a $\mathrm{ZrB}_{2}$ and $\mathrm{CrB}_{2}$ mixture), IT-1 (23\% $\mathrm{Al}_{2} \mathrm{O}_{3}, 77 \%$ $\mathrm{Cr}), \operatorname{IT}-1 \mathrm{~B}\left(19 \% \mathrm{Al}_{2} \mathrm{O}_{3}, 59 \% \mathrm{Cr}, 20 \% \mathrm{MO}_{2} 2 \% \mathrm{TiO}_{2}\right), \mathrm{Al}_{2} \mathrm{O}_{3}$, $\mathrm{BCO}$, and $\mathrm{CrB}_{2}$. In this series of tests, a small sample of each ceramic material was placed in contact with a small sample of Haynes-25 material and the assembly heated as in the foil experiments.

B. TEST DATA, RESULTS, AND CONCLUSIONS

Photographs, test conditions, and reduced data from the various tests conducted are listed in Table 1 . In all cases where Haynes-25 failed to bond with the graphite cylinder, the Haynes-25 sample is shown separately in the photographs, Figures 1 and 2 .

The results of these tests showed that zirconium foil was the best material for preventing chemical reaction and subsequent adhering between Haynes-25 and graphite, particularly at $2700^{\circ} \mathrm{F}$. This foil appears to have completely prevented contact between the two materials for at least 15 minutes. The foil material oxidizes to a light fluffy oxide which breaks up easily in an air stream. Titanium foil was the next best material; but it showed a slight 
penetration by molten Haynes-25, permitting some reaction with the graphite. Tantalum, tungsten and columbium foils produced gross reactions and would not be considered in any future designs.

Of the ceramic materials tested in direct contact with Haynes-25, BeO and IT-1 showed the greatest resistance to chemical and mechanical reactions. All other ceramic materials tested showed some degree of reaction.

From these tests, zirconium foil was shown to be the best material in which to enclose the Haynes fuel capsule within graphite. Ceramic heat accumulator block material substitutes will have to be parameterized in terms of generator operation before they can be considered. Such an operation is beyond the scope of this test program. 
TEST DATA AND RESULTS

HIGH TEMPERATURE MATERIALS COMPATIBILITY TESTS

\begin{tabular}{|c|c|c|c|c|}
\hline $\begin{array}{l}\text { Test } \\
\text { Run } \\
\end{array}$ & Test Mode1 & $\begin{array}{c}\text { Test } \\
\text { Environment }\end{array}$ & $\begin{array}{l}\text { Temp. } \\
(\cdot \mathbb{F})\end{array}$ & $\begin{array}{c}\text { Exposure } \\
\text { Time } \\
\text { (Min) } \\
\end{array}$ \\
\hline 1 & 0.001 Titanium foil & Air & 2700 & 15 \\
\hline 2 & 0.0008 Zirconium foil & Air & 2700 & 15 \\
\hline 3 & 0.001 Tantalum foil & Air & 2700 & 15 \\
\hline 4 & 0.005 Tungsten foil & Air & 2700 & 15 \\
\hline 5 & 0.001 Titanium foil & Hydrogen & 2425 & 15 \\
\hline 6 & 0.0008 Zirconium foil & Hydrogen & 2425 & 15 \\
\hline 7 & 0.001 Tantalum foil & Hydrogen & 2425 & 15 \\
\hline 8 & 0.005 Tungsten foil & Hydrogen & 2425 & 15 \\
\hline 9 & 0.001 Columbium foil & Hydrogen & 2425 & 15 \\
\hline 10 & $\mathrm{ZrB}_{2}$ and Haynes-25 & Air & 2700 & 15 \\
\hline 11 & Borolite and Haynes-25 & Air & 2700 & 15 \\
\hline 12 & LT -1 and Haynes-25 & Air & 2700 & 15 \\
\hline 13 & LT-1B and Haynes-25 & Air & 2700 & 15 \\
\hline 14 & $\mathrm{~A}_{2} \mathrm{O}_{3}$ and Haynes-25 & Air & 2700 & 15 \\
\hline 15 & BeO and Haynes-25 & Air & 2700 & 15 \\
\hline 16 & $\mathrm{CrB}_{2}$ and Haynes-25 & Air & 2700 & 15 \\
\hline 17 & $\mathrm{ZrB}_{2}$ and Haynes-25 & Hydrogen & 2425 & 15 \\
\hline 18 & Borolite and Haynes-25 & Hydrogen & 2425 & 15 \\
\hline 19 & LT- 1 and Haynes-25 & Hydrogen & 2425 & 15 \\
\hline 20 & LT $-1 B$ and Haynes-25 & Hydrogen & 2425 & 15 \\
\hline 21 & $\mathrm{Al}_{2} \mathrm{O}_{3}$ and Haynes-25 & Hydrogen & 2425 & 15 \\
\hline 22 & $\mathrm{BeO}$ and Haynes-25 & Hydrogen & 2425 & 15 \\
\hline
\end{tabular}

Results

Slight penetration of Haynes-25 through foil and reaction with graphite, Figure 1.

No penetration of Haynes 25 through foil. Graphite surface completely clean. No apparent reaction between Haynes-25 and foil, Figure 1.

Gross reaction among foil, Haynes -25 , and graphite, Figure 1. Gross reaction among foil, Haynes-25, and graphite, Figure 1. Reaction between Haynes-25 and foil but not between foil and graphite. Graphite surface completely clean, Figure 2.

Slight reaction between Haynes -25 and foil but not between foil and graphite. Graphite surface completely clean, Figure 2 .

Gross reaction among foil, Haynes-25, and graphite, Figure 2. Reaction between Haynes -25 and foil but not between foil and graphite. Graphite surface completely clean, Figure 2.

Gross reaction among foil, Haynes-25, and graphite, Figure 2. Slight reaction and sticking. Haynes-25 broke away on cooling, Figure 3 .

Considerable reaction and sticking, Figure 3.

No visable evidence of reaction and no sticking, Figure 3.

Considerable reaction and sticking, Figure 3 .

Slight reaction and sticking. Haynes-25 broke away on cooling, Figure 3 .

No visable reaction or sticking, Figure 3.

Severe reaction, Figure 3.

Slight evidence of reaction. No sticking, Figure 4.

No reaction of sticking, Figure 4.

No reaction or sticking, Figure 4.

No reaction or sticking, Figure 4

No reaction or sticking, Figure 4.

No reaction or sticking, Figure 4. 

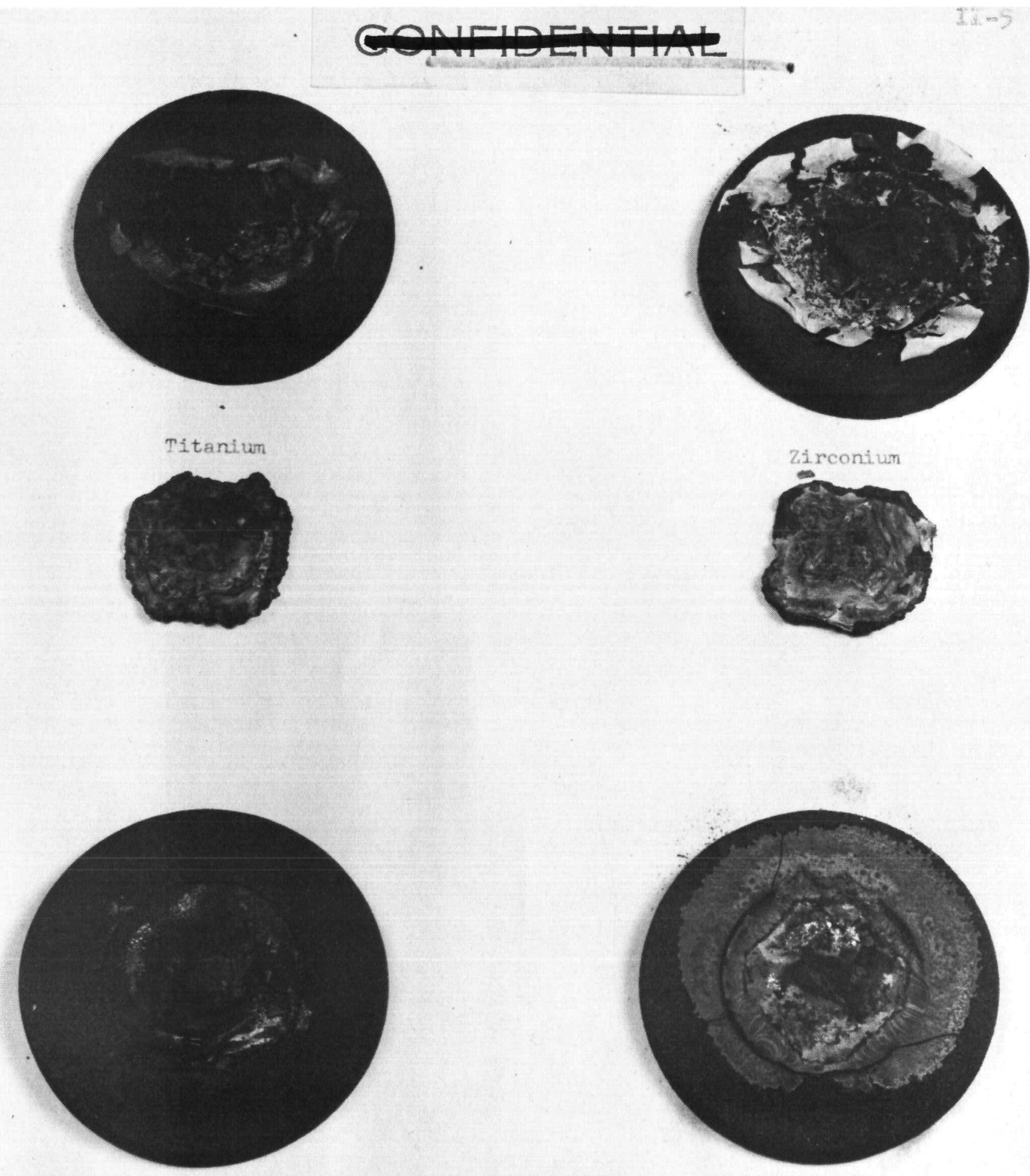

Tantelum
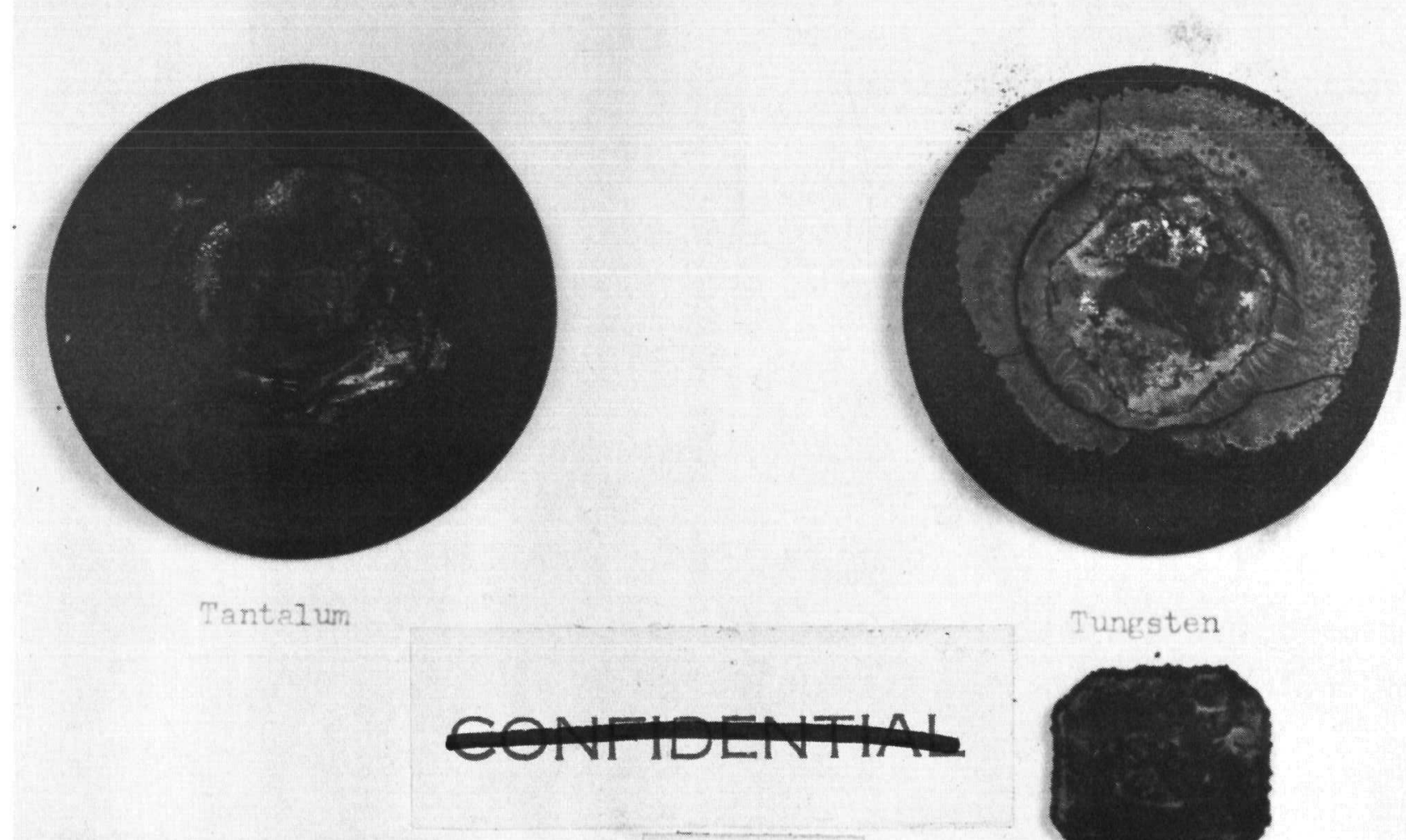

\section{Figure 1}

Foil Test Specimens after High Temperature Exposure in Air

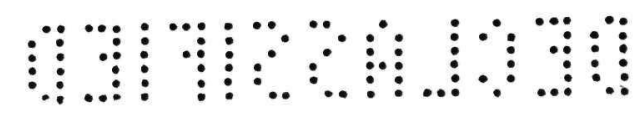




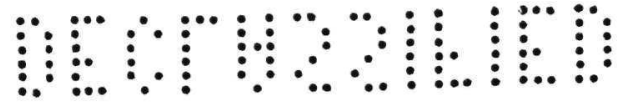

$\operatorname{II}-6$

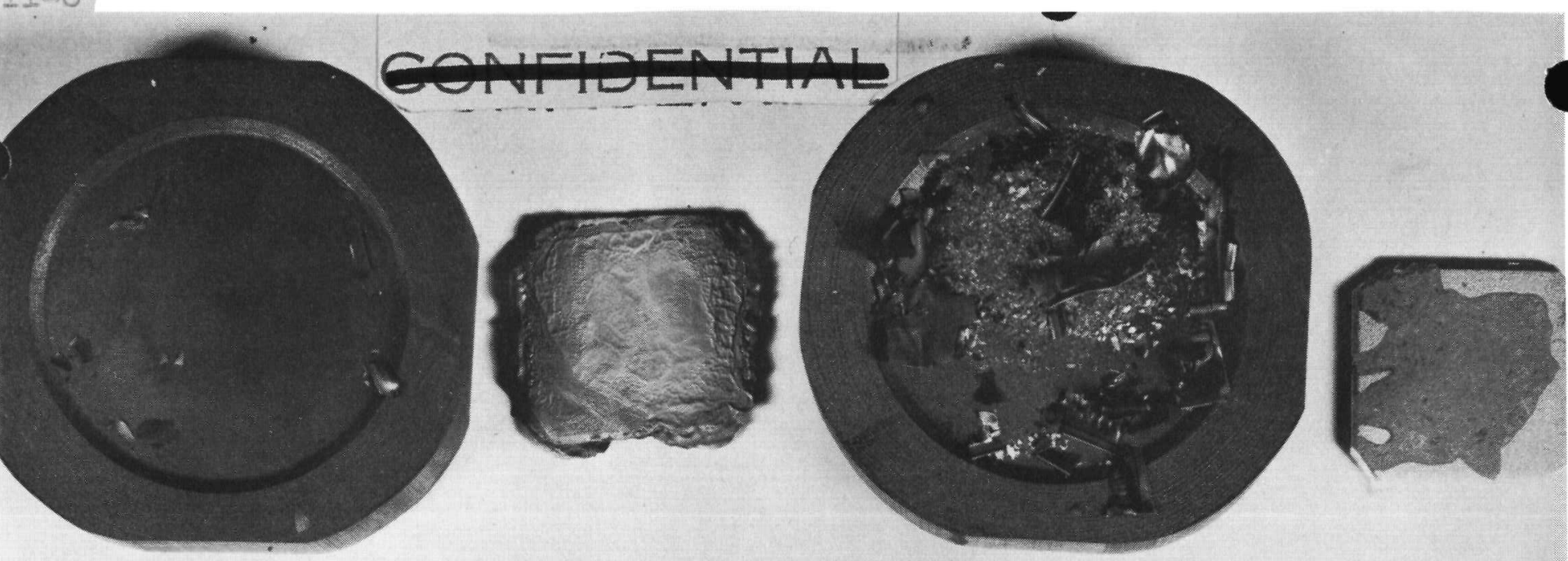

itanium

Zirconium

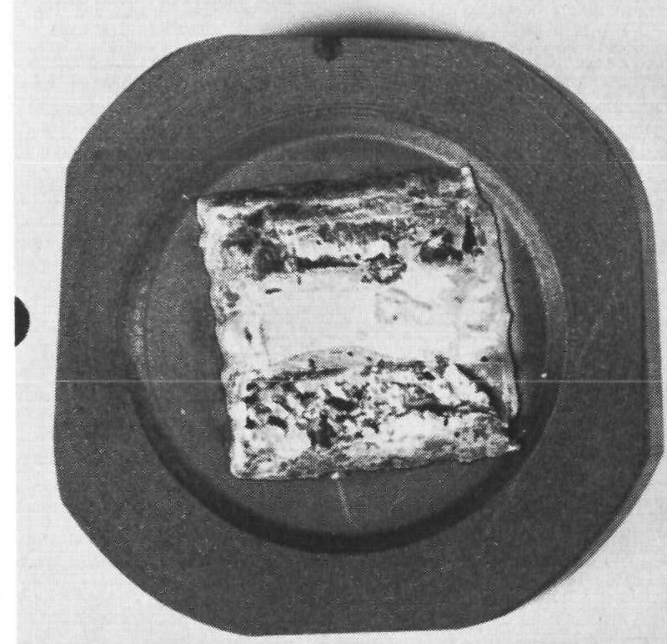

Tantalum

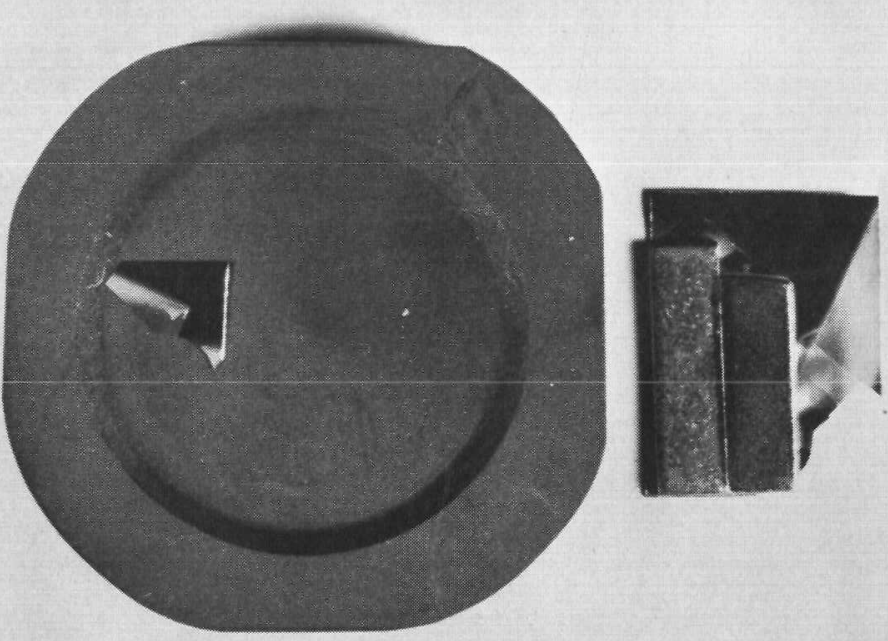

Tungsten

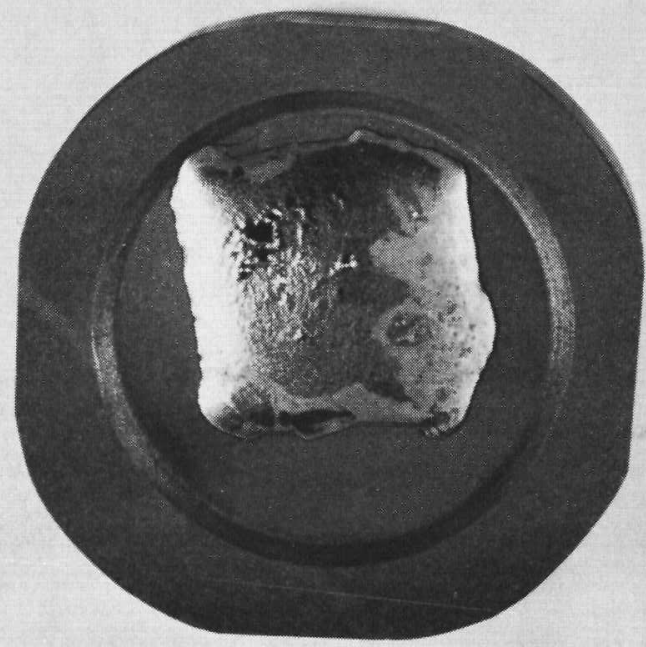

GOivi

Figure 2

:: :: : $:$ Foł

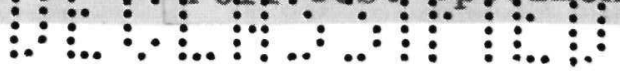




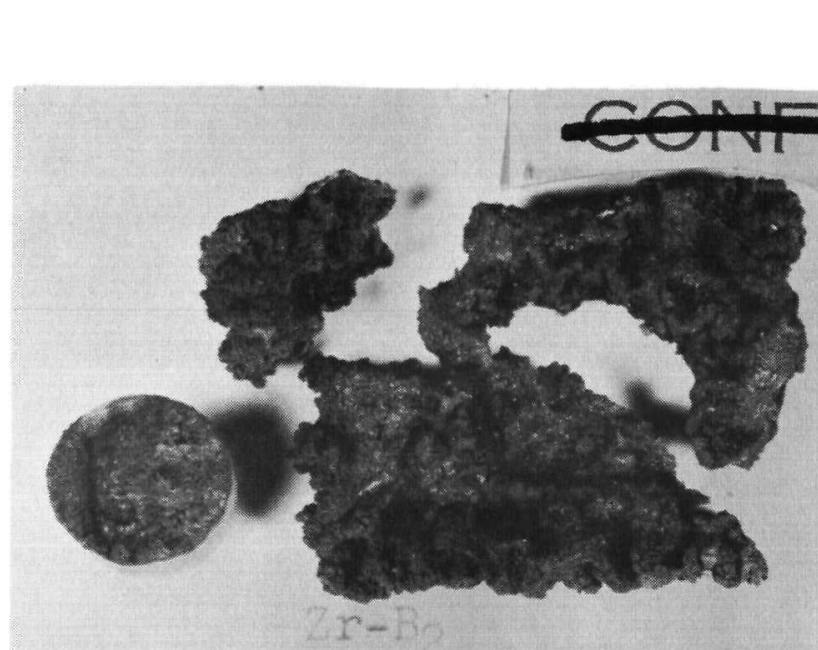

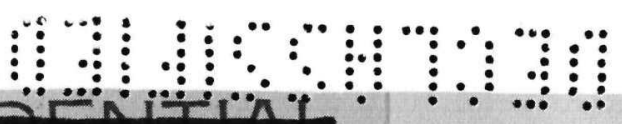
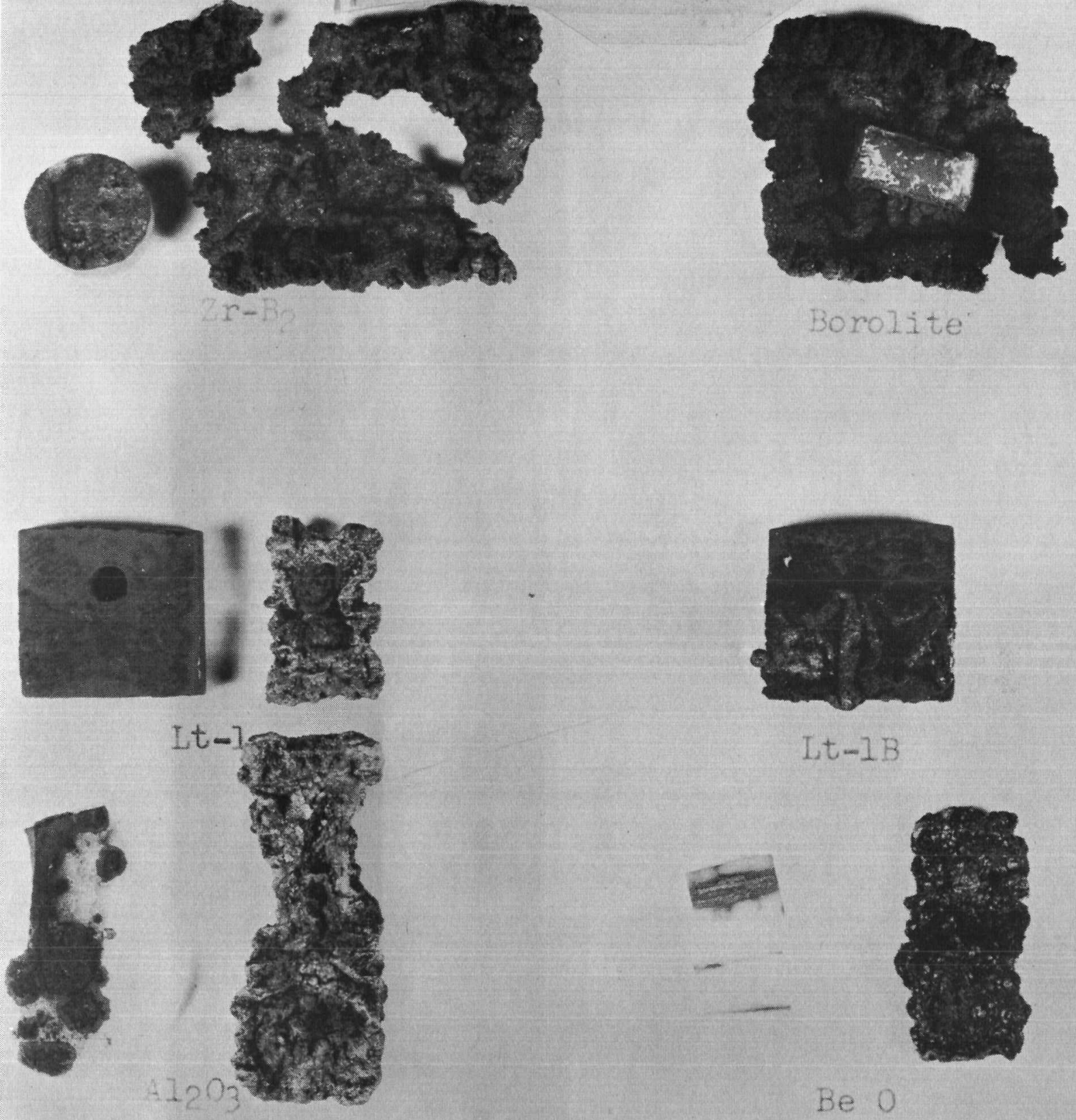

Borolite

$1, t-1 B$

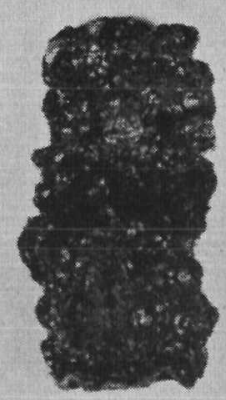

Be 0

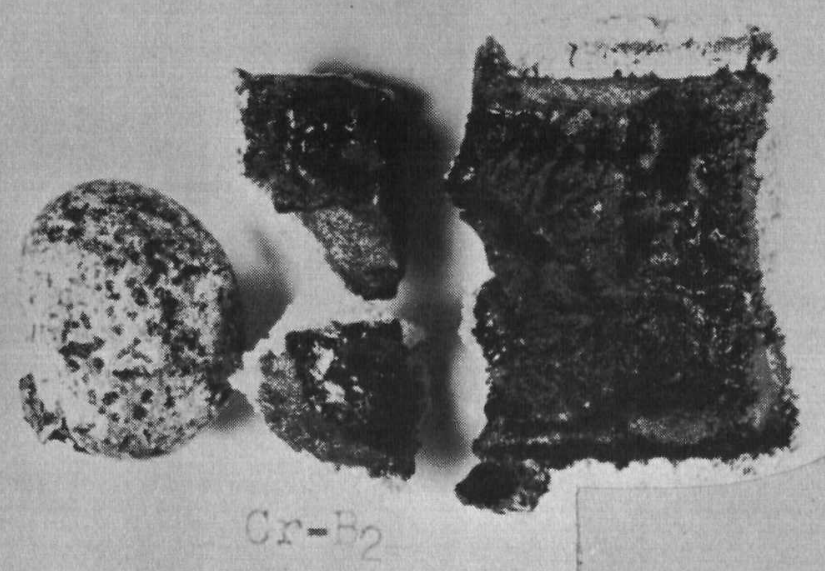

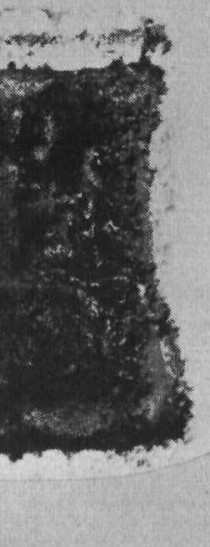

2คMILIDENITIAL

Figure 3

Ceramic Test Specimens after High Temperature Exposure in Air 
$\because \ldots .$. $\because \cdots:$ $\because \cdots$. $\because \cdots$ $\because \cdots$ $\therefore$ $: \therefore$

......

$\cdots \cdots$

:...: :.....
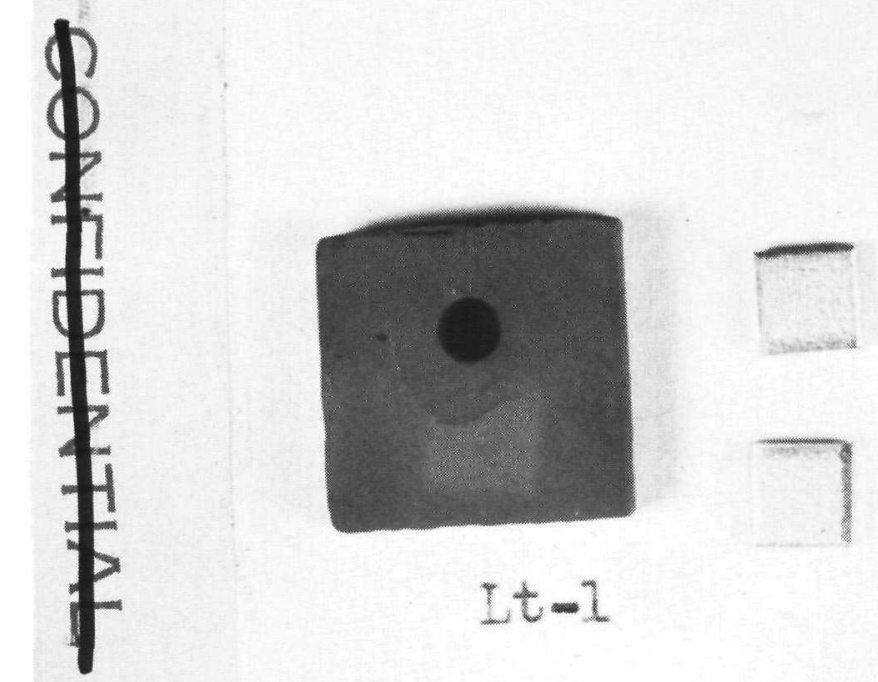

It -1

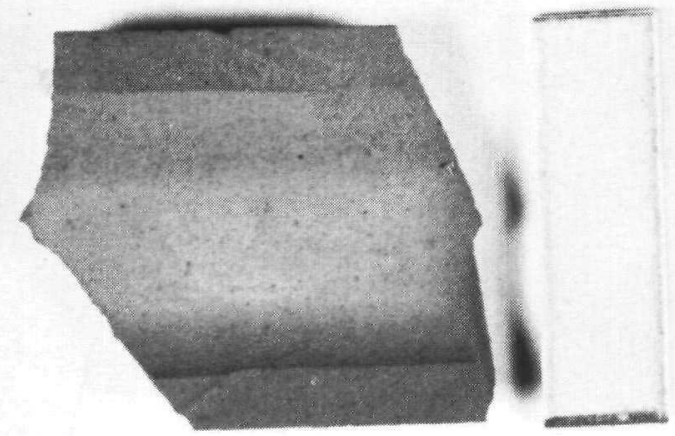

$\mathrm{A}_{2} \mathrm{O}_{3}$
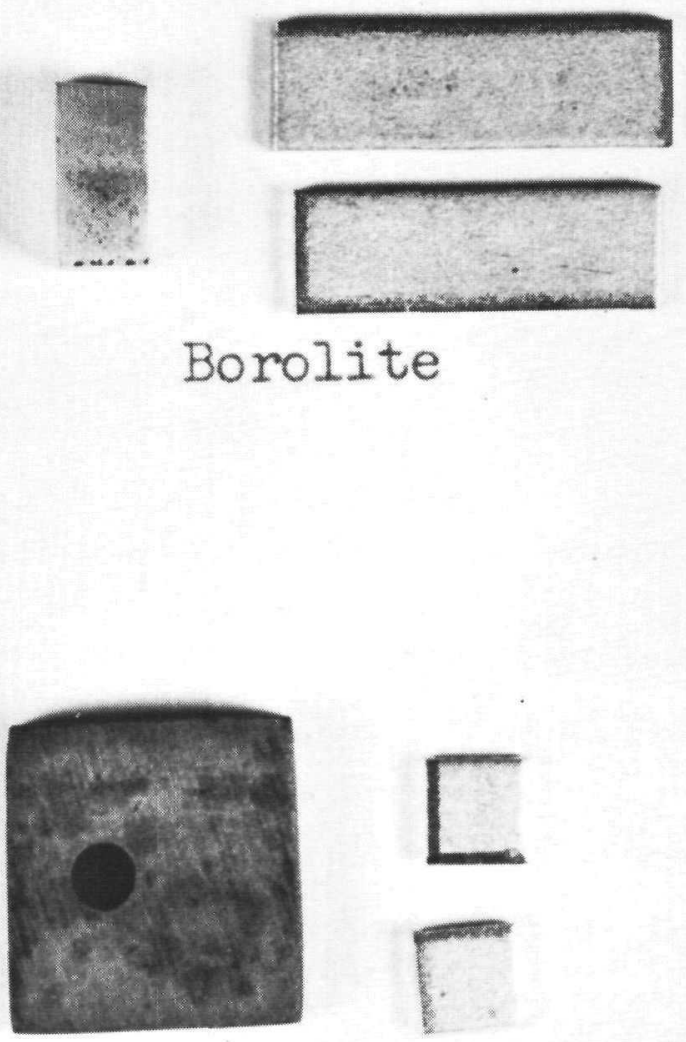

$L t-1 B$

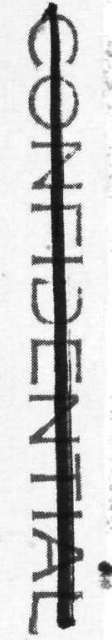

Figure 4

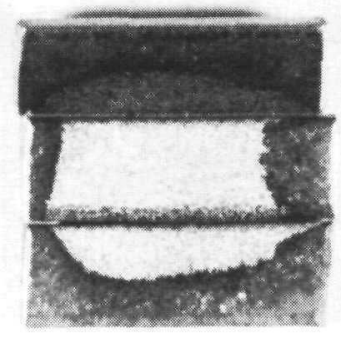

Be 0

Ceramic Test Specimens after High Temperature Exposure in Hydrogen 


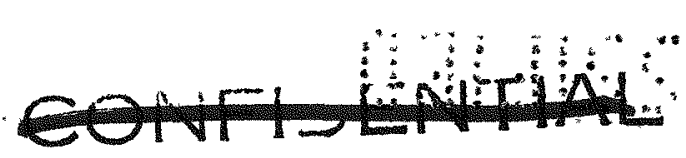

III-I

\section{PLASMA ARC TEST}

A two series plasma test program was conducted to evaluate dynamic thermal characteristics of materials used in space power systems when exposed to aerothermodynamic forces of re-entry. This program was designed to complement the work done under the static high temperature materials compatibility test series described previously and earlier SNAP 9A tests. It has become apparent that determination of material characteristics in a simulated re-entry environment is required to better assess the safety of a space power system. However, caution must be taken in establishing the test environment because the sensitivity of the plasma arc may otherwise limit the usefulness of the results.

The specific objectives of these plasma tests were to:

1. Determine ablation rates of materials such as tanteavr, Hayses 25, magnesium and Min-K insulation.

2. Determine the chemical reactions or lack of reactions of graphite and boron nitride, materials which could be used in the design of heat accumulator blocks, with other materials present in the generator.

3. Investigate the effects of oxidation on all these materials, especially tantalum, and

4. Evaluate the use of aluminum oxide on the ends of fuel capsules to prevent melting of the fuel capsule before it is released from the generator structure during re-entry. This condition 
is particularly important if the generator orients itself in a stable mode with its longitudinal axes parallel to the flight path.

Test models, numbering 34, were designed in accordance with actual generator components. All were fabricated from flight generator stock material and most were full-scale.

This section of the report discusses the work which was accomplished during the test program. It includes a discussion on re-entry simulation with the plasma arc, a summary of test parameters and procedures, a description of the test specimens, an outline of data accumulated before, during and after the test, and a discussion of the results and conclusions of the program. 


\section{A. PIASMA ARC RE-ENTRY SIMULATION}

The plasma arc system operates on the principle of creating an electrical arc between two electrodes through which flows a working media, converting electrical energy into thermal energy, and exhausting this media through a nozzle into the test section. The plasma generation system consists of a plasma head (anode, cathode, oxygen and nitrogen inlets, and coolant channels), a mixing chamber, and a supersonic nozzle. The nitrogen portion of the working media enters the arc chamber tangentially, thus providing a vortex at the cathode where it is heated and stabilized. Oxygen is injected at the anode (in order to prevent oxidation of the tungsten cathode) to create a simulated air composition. The working media flows into the mixing chamber where it is compressed to achieve sonic velocity at the throat, and then expanded to supersonic conditions (Mach $=3.0$ ) at the nozzle exit. Photographs of the Martin plasma arc system are shown in Figures 5 and 6 (Reference 1 ).

Maximum capabilities of the system are:

1. Stagnation enthalpies up to $12,000 \mathrm{BTU} / 1 \mathrm{~b}$.

2. Heat fluxes from 6 to $300 \mathrm{BTU} / \mathrm{sec}-\mathrm{ft}^{2}$ using two contoured Mach 3 nozzles.

3. Input power up to $300 \mathrm{kw}$.

4. Nozzle exit sizes for Mach 3 flow of 1.5 and 3 inches.

5. Test chamber pressures from 100 microns to I atmosphere.

All instrumentation used in establishing test environments or in the acquisition of test data were 


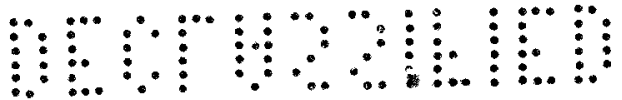

$I I I-4$

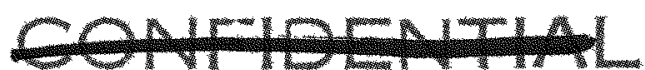

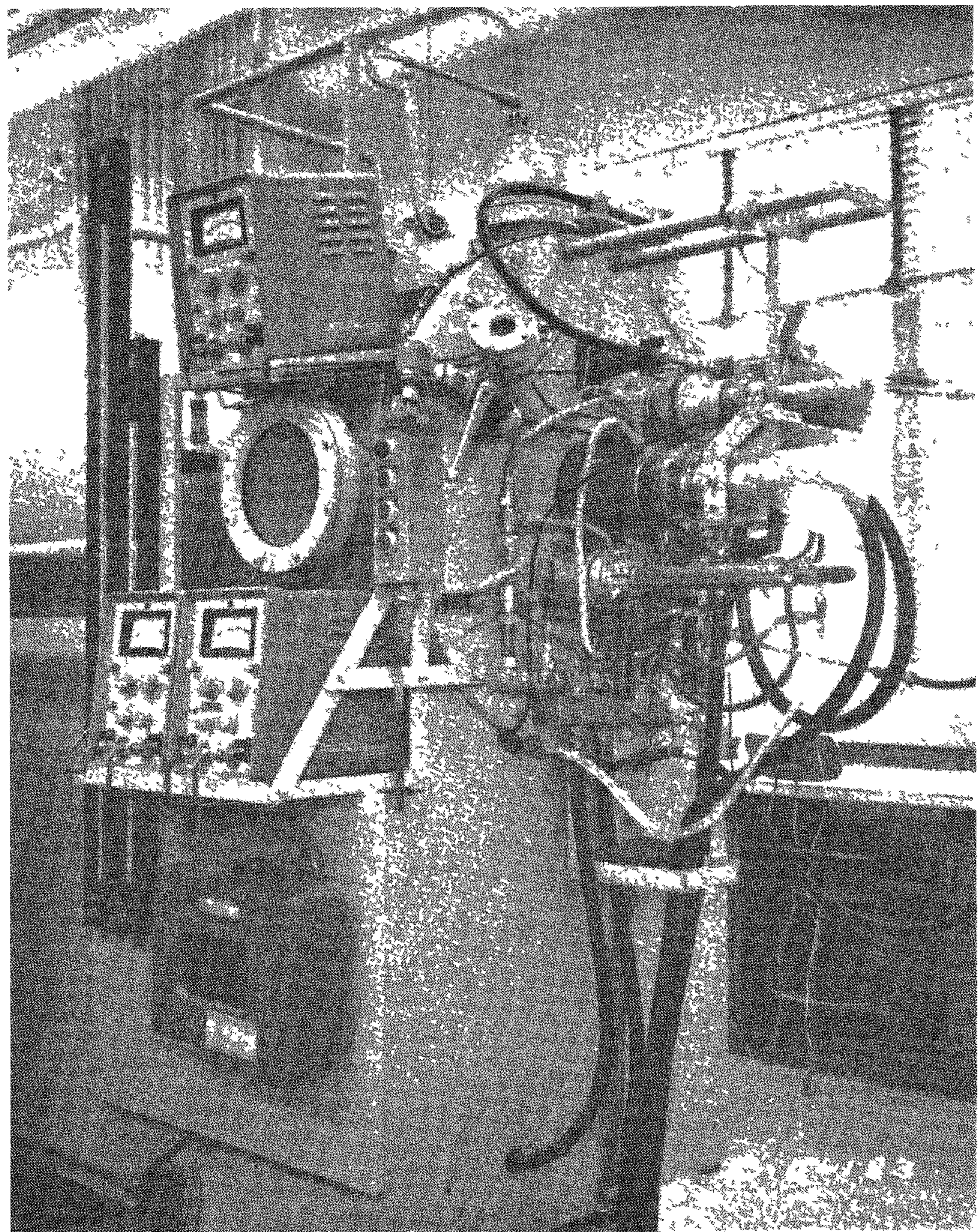

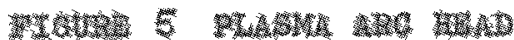




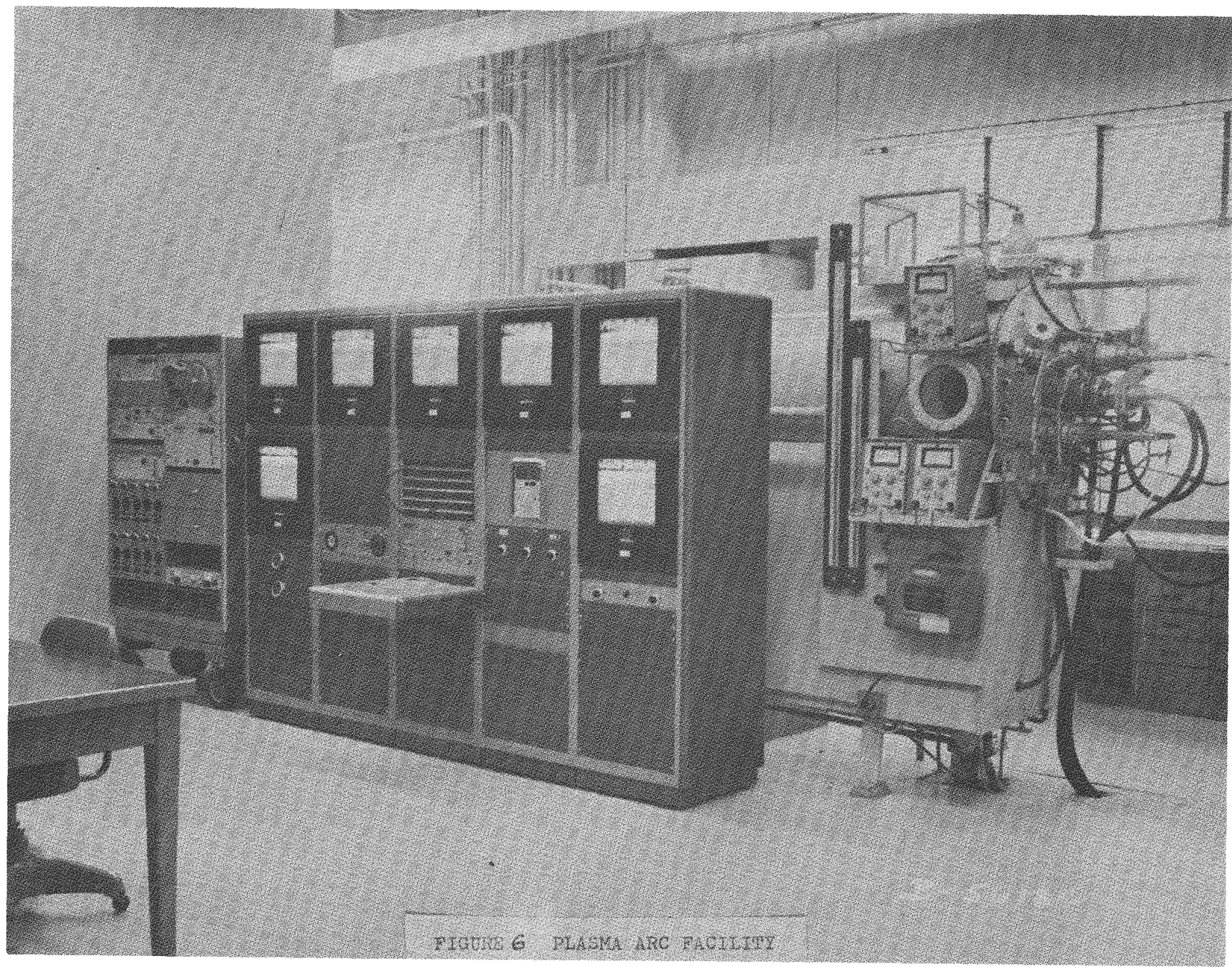

$\because \therefore$

$\because \because$

$\because::$

$\because .$.

$\therefore .$. 
calibrated and are shown in Table 2.

The desired test conditions are those which duplicate, on a time basis, the aerodynamic, thermal, and chemical parameters of a re-entry environment. However, time simulation of re-entry phenomena is difficult to accomplish using existing test facilities. Therefore, re-entry characteristics must be evaluated from tests in which only the major environmental parameters (enthalpy, heat flux, and pressure) are simulated. This technique places stringent restrictions on the utilization and extrapolation of resulting data.

One difficulty of the plasma arc is the simulation of Mach 15 to 25 conditions in a Mach 3 test environment. The primary difference between test conditions and flight conditions, as a result of the arc's low Mach number, is the time the plasma is allowed to interact with or diffuse into the surface of the model. This phenomenon is postulated on the basis of the shock wave behavior illustrated in Figure 7 and described as follows:

1. In the hypersonic environment (Mach 15 to 25), the shock wave attaches very closely around the model, resulting in relatively high velocity flow between the hypersonic shock wave and the model.

2. In the plasma arc (Mach 3), the shock wave is farther detached from the model resulting in low velocity flow conditions. As such more time is allowed for surface interactions to take place.

If optimum plasma flow is to be obtained, plasma arc testing requires that the differential between nozzle static pressure and test chamber static pressure be zero 
TABLE 2

TEST EQUIPMENT CHARACTERISTICS

\section{Equipment}

Voltmeter

Ammeter

Critical

orifices

Pressure gages

Flow meter

Differential pressure meter

\section{Millivolt}

recorders

Pitot Probe

$$
\text { Range }
$$

$0-15 \mathrm{~V}$

$0-75 \mathrm{~V}$

$0-300 \mathrm{~V}$

O-3000A

Different

sizes

$0-200$ psia

$0-20 \mathrm{gpm}$

Multirange

$0-30 \mathrm{~mm} \mathrm{Hg}$

Multirange

$\mathrm{O}-30 \mathrm{~mm} \mathrm{Hg}$ $\pm 0.5 \%$

$\pm 3 \%$ full scale

Tolerance

$\pm 1 / 4 \%$ full scale

$\pm 1 / 4 \%$ full scale

$\pm 1.0 \%$

$\pm 0.1 \%$ full scale

$\pm 1 / 4 \%$ full scale
Use

Measure arc voltage

Measure arc current Gas mass flow rate

Used in conjunction with orifices to measure gas mass flow rate

Head and nozzle water flow rate

Stagnation pressure, nozzle static pressure and chamber pressure

Record thermocouples output, water flow and radiation pyrometer output

Measure stagnation pressure of stream

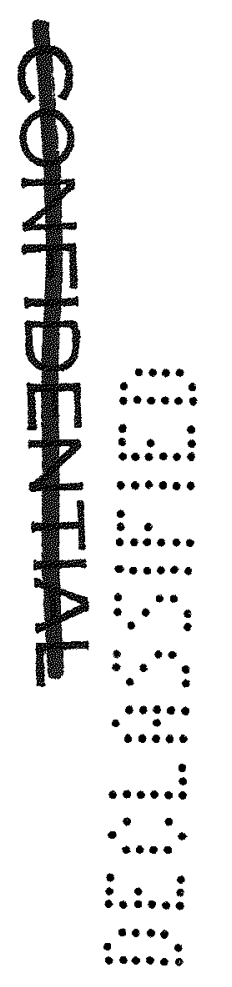


TABLE 2

TEST EQUIPMENT CHARACTERISTICS (Continued)

Equipment

$$
\text { Range }
$$

$2000-4600^{\circ} \mathrm{F}$

pyrometer

Optical

pyrometer

$1400-7600^{\circ} \mathrm{F} \quad \pm 15^{\circ} \mathrm{F}$

\section{Use}

Model surface

temperature

Model surface

temperature $\because \cdots: \cdot$

$\because \because \cdots$

$\because \because \cdot$

(…:

$\because \ldots$

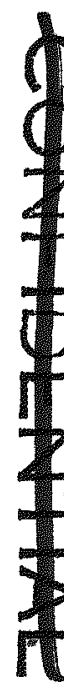




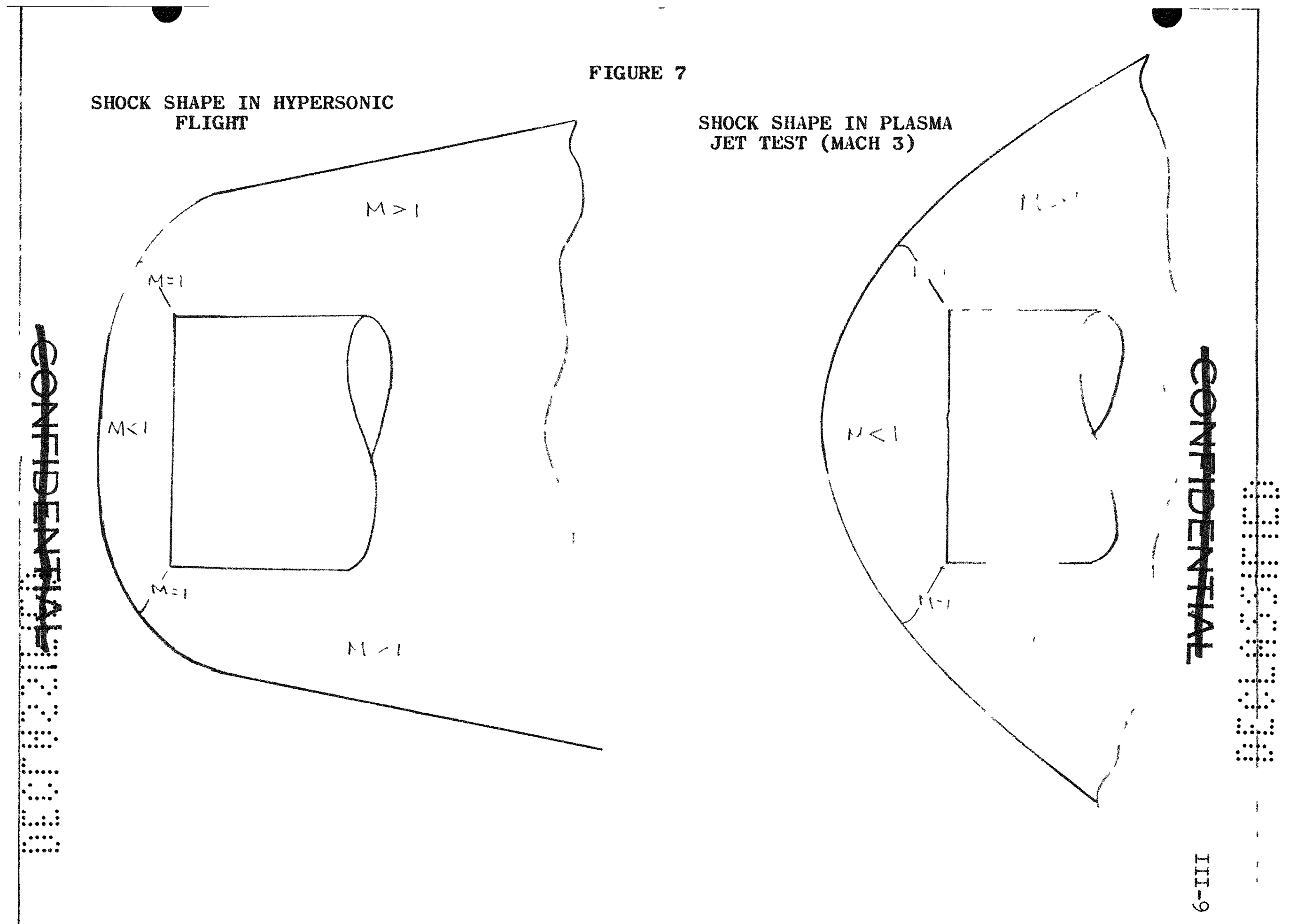


(Reference 2). If this condition is not satisfied the following may exist:

1. Underexpanded flow if the nozzle static pressure is greater than the chamber pressure.

2. Overexpanded flow if the nozzle static pressure is less than the chamber pressure.

Both under - and over expanded flow can result in oblique shock waves impinging upon the model, greatly changing the environmental parameters of heat flux and pressure. Aschematic illustrating the three flow conditions is given in Figure 8. 


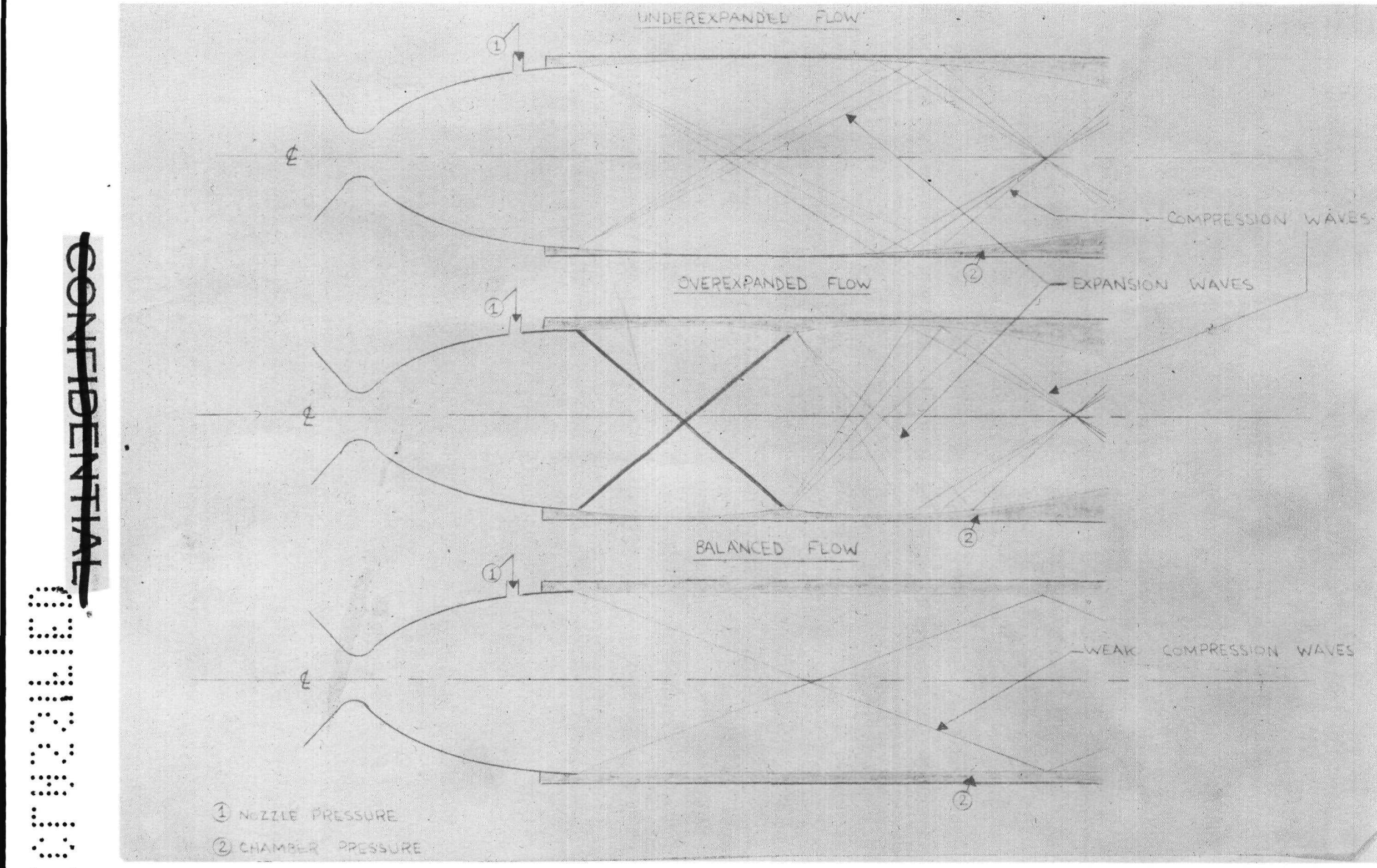




\section{B. TEST PARANETERS AND PROCEDURES}

The major re-entry environmental parameters associated with aerothermodynamic investigations are stagnation enthalpies, heat fluxes, stagnation pressures, and shearing stress. Proper simulation of flight conditions by a plasma facility requires that these parameters be capable of being varied independently. Since they are not completely independent, the degree of simulation that can be accomplished by a plasma arc is limited to the equipment capabilities of power, mass flow rate, and pressure.

In order to determine optimum plasma test environments for the various test models, theoretical analyses were made based on the orbital decay re-entry trajectory of the SNAP 9A (Reference 3) for the first series of tests and on the flight path trajectory of the RFD-2 experiment (Reference 4) for the second series. Since ideal re-entry conditions simulated on a time basis could not be attained, selected point values were chosen from the trajectory parameters that represent the re-entry time span. The selected points had to be further modified to fit within the plasma arc capabilities.

In an attempt to compensate for the arc stagnation pressure limitation, the working media's oxygen concentration was increased in one run thus approaching a high oxygen partial pressure. An analysis was performed to calculate the oxygen available on re-entry so that the desired quantity flowing through the arc could be determined. This analysis is explained in Appendix A.

The following are test procedures utilized:

1. Calibrate test environment (determine total 
enthalpy, heat flux, and pressure.)

2. Expose the model to the plasma after specific characteristics were exhibited.

3. Nonitor the model surface temperature with a total radiation pyrometer and optical pyrometer.

4. Record model burnup characteristics on film as a function of time ( $0.7 \mathrm{frame} / \mathrm{sec}$ and 16 frames/. $s \in c)$.

Total enthalpy is calculated from the following relationship:

$$
\mathrm{H}_{\mathrm{T}}=\frac{9.478 \times 10^{-4}(\mathrm{E})(\mathrm{I})-0.1390\left(\mathrm{~V}_{\mathrm{HW}}\right)\left(\mathrm{T}_{\mathrm{HW}}\right)\left(\mathrm{V}_{\mathrm{NW}}\right)\left(\mathrm{T}_{\mathrm{NW}}\right)}{\mathrm{m}}
$$

where: $\quad H_{T}$ - total enthalpy (BTU/Ib)

E - voltage (volts)

$I$ - current (amperes)

$\mathrm{V}_{\mathrm{HW}}$ - arc generator cooling water flow rate (GPM)

$\mathrm{T}_{\mathrm{HW}}$ - arc generator cooling water temperature rise $\left({ }^{\circ} \mathrm{F}\right)$

$\mathrm{V}_{\mathrm{NW}}$ - nozzle cooling water flow rate (GPM)

$\mathrm{T}_{\mathrm{NW}}$ - nozzle cooling water temperature rise $\left({ }^{\circ} \mathrm{F}\right)$

m - gas flow rate $(\mathrm{lb} / \mathrm{sec})$

The stagnation heat flux was determined by using a slug-type transient calorimeter, in which a known quantity of thermally isolated mass was heated and its temperature response recorded. The heat flux sensed was determined by:

$$
\dot{q}=\frac{M C p}{A} \quad \frac{d T}{d t}
$$




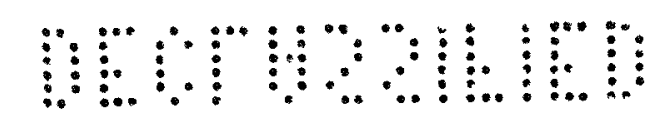

$\operatorname{II}-14$

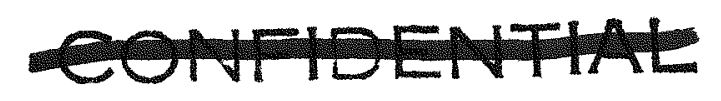

$$
\begin{aligned}
& \dot{q} \text { - heat flux (BTU/ft } \text {-sec) } \\
& M \text { - mass (Ibs) } \text { - heat sensing area }\left(f t^{2}\right) \\
& \text { Cp - specific heat of sensor }\left(B T U / I b-{ }^{\circ} \mathrm{F}\right) \\
& \frac{\mathrm{dT}}{\mathrm{dt}}-\operatorname{slope~of~temperature~versus~time~curve~} \\
&\left({ }^{\circ} \mathrm{F} / \mathrm{sec}\right)
\end{aligned}
$$

A water cooled calorimeter (steady-state) was used to insure reproducibility of test environments. This calorimeter was calibrated at each test point using the transient calorimeter.

Stagnation pressures were determined with a pitot tube connected to the differential manometer referred to in Table 2.

Model burnup characteristics were determined by developing a model representing the physical state of the body. Such a model is illustrated in Figure 9, (Reference 5).

The shock vave causes heating, velocity, and shearing stress gradiants across the frontal surface of the reentry body, (Reference 6). Aerodynamic heat transfer to a body is diverted by conduction, vaporization, fusion, and by radiation, (Reference 7 ).

$$
\begin{aligned}
q_{\text {in }}= & q_{\text {vaporization }}+q_{\text {fusion }}+q_{\text {conduction }}+ \\
& q_{\text {radiation }}+q_{\text {stored }}
\end{aligned}
$$

The term $q_{\text {vaporization, a function of the gas injection }}$ rate of the material, contributes greatly to diverting the aerodynamic heating. This mechanism is known as transpiration or blocking effect. 

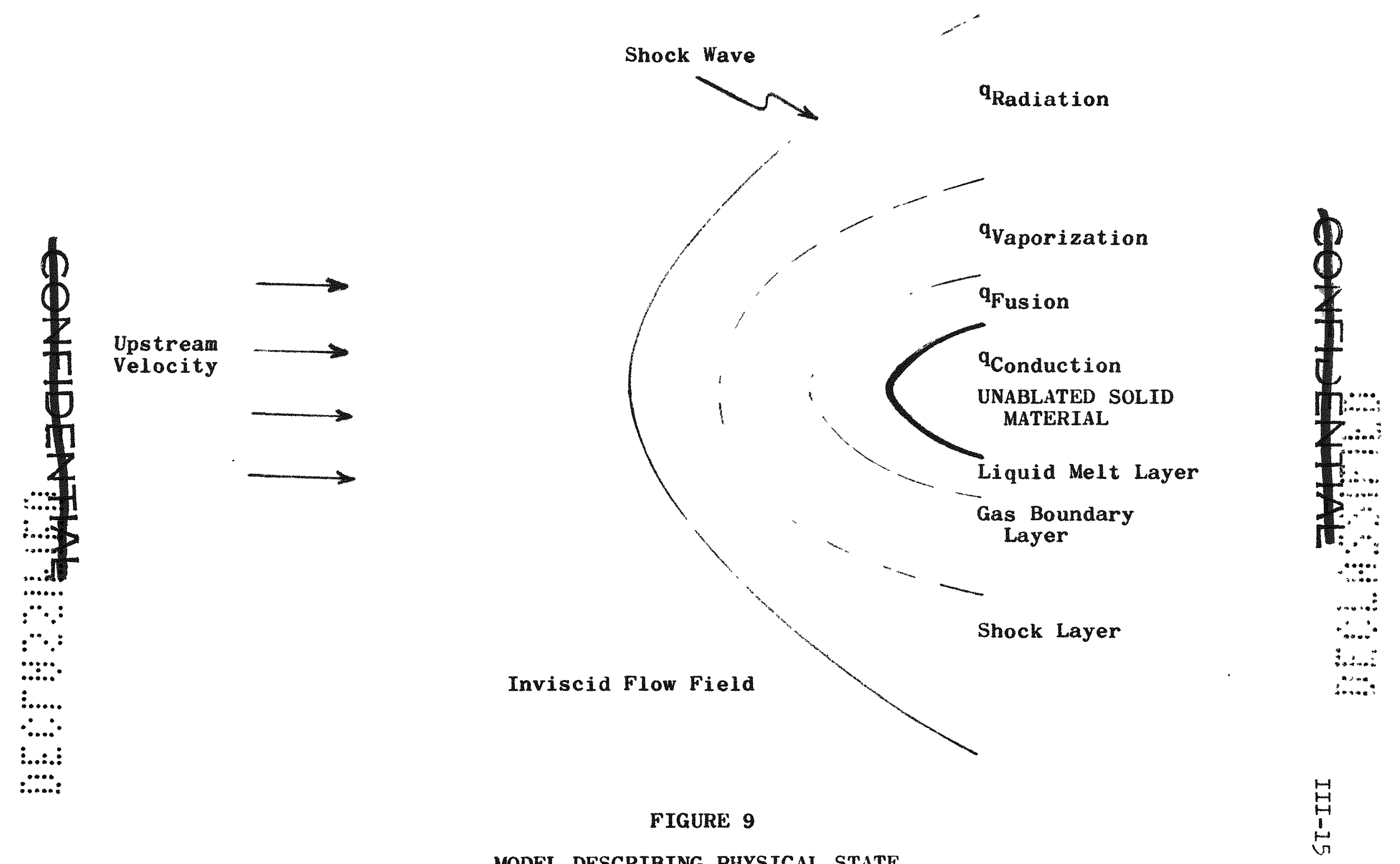

MODEL DESCRIBING PHYSICAL STATE 
The term $q_{\text {fusion }}$ is the quantity that is directly diverted by the melt layer of the body. If a large percentage of aerodynamic heating is diverted by this quantity, the body will have a better chance to completely vaporize and disperse upon re-entry providing that the shearing forces are great enough to remove the melt layer as it is formed. 


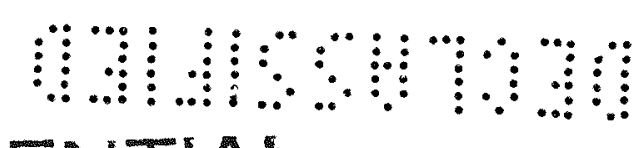

\section{TEST SPECIMENS}

Test specimens were designed in accordance with actual flight model generators. The models were fabricated of flight generator stock materials, utilizing full-scale components where possible. Model designations, quantities, and characteristics of each of the 34 specimens tested are summarized in Table 3. Nore detailed information of the specimens is presented in the pest Data section.

1. Tantalum Oxidation Model (Type 1)

The purpose of these models was to investigate the behavior of tantalum under simulated re-entry conditions. Oxidation rates and post-test material conditions were of greatest interest. A typical test model is shown in Figure 10.

\section{Tantalum Fuel Liners (Types 2, 6, and 7)}

These fuel liners were tested to determine the heating time required to breach the fuel container and to evaluate the mechanism of failure. Copper slugs were used as fuel simulators and heat sinks in the liners of Type 2. No heat sink material was used in models of Types 6 and 7 since these simulate capsules of the RFD-2 experiment which will contain an insulator between the liner and the flare material. A typical fuel liner along with a copper fuel simulator is shown in Figure 11.

3. Fuel Capsule Assembly (Types 3, 8, and 9)

Complete fuel capsule assemblies were tested to evaluate their behavior after release from the generator structure under simulated re-entry conditions. 


\section{TABLE 3}

SUMMARY OF SPECIMEN CONFIGURATION CHARACTERISTICS

\begin{tabular}{|c|c|c|c|}
\hline $\begin{array}{l}\text { Specimen } \\
\text { Type }\end{array}$ & $\begin{array}{l}\text { Model } \\
\text { Designation }\end{array}$ & $\begin{array}{l}\text { Quantity } \\
\text { Tested }\end{array}$ & Model Characteristics \\
\hline 1 & $T$ & 2 & $\begin{array}{l}\text { Tantalum oxidation model, } 7 / 8 \text { dia. rod } 1 / 1 / 2 \\
\text { long. }\end{array}$ \\
\hline 2 & $\mathrm{~T} 20-\mathrm{C}$ & 2 & SNAP 9A Tantalum liner with copper slug. \\
\hline 3 & FHT & 1 & SNAP 9A Fuel Capsule (full scale) \\
\hline 4 & GGI & 1 & $\begin{array}{l}\text { Simulated generator with graphite } \\
\text { heat accumulator. }\end{array}$ \\
\hline 5 & GBI & 1 & $\begin{array}{l}\text { Simulated generator with boron nitride } \\
\text { heat accumulator. }\end{array}$ \\
\hline 6 & T20 & 4 & $\begin{array}{l}\text { SNAP } 9 A \text { Tantalum liner, no simulated fuel, } \\
0.7740 . \mathrm{D} ., 11 / 2 \text { long. }\end{array}$ \\
\hline 7 & T6 & 3 & 6 mil Tantalum capsule. $0.7320 .0 .11 / 2$ long. \\
\hline 8 & $\mathrm{HT}$ & 4 & $\begin{array}{l}50 \text { mil Haynes-25 capsule with } 6 \text { mil tan- } \\
\text { talum liner. } 0.8400 .0 ., 13 / 410 \mathrm{ng} \text {. }\end{array}$ \\
\hline 9 & AHT & 4 & $\begin{array}{l}\text { Same as Type } 8 \text { with } 0.187 \text { thick aluminum } \\
\text { oxide cap. }\end{array}$ \\
\hline 10 & GIA & 4 & $\begin{array}{l}\text { Simulated generator with segmented graph- } \\
\text { ite and insulation, and solid Haynes rod } \\
\text { with } \mathrm{Al}_{2} \mathrm{O}_{3}\end{array}$ \\
\hline
\end{tabular}


TABLE 3 (CONTINUED)

SUMMARY OF SPECIMEN CONFIGURATION CHARACTERISTICS

\begin{tabular}{|c|c|c|c|}
\hline $\begin{array}{l}\text { Specimen } \\
\text { Type }\end{array}$ & $\begin{array}{l}\text { Model } \\
\text { Designation }\end{array}$ & $\begin{array}{l}\text { Quantity } \\
\text { Tested }\end{array}$ & Model Characteristics \\
\hline 11 & GIB & 4 & $\begin{array}{l}\text { Same as Type } 10 \text { except designed to be } \\
\text { tested at } 90^{\circ} \text {. }\end{array}$ \\
\hline 12 & G2 & 1 & $\begin{array}{l}\text { Simulated generator with segmented graphite, } \\
\text { solid insulation wall, and solid Haynes } \\
\text { rod with } \mathrm{Al}_{2} \mathrm{O}_{3}\end{array}$ \\
\hline 13 & G3 & 1 & $\begin{array}{l}\text { Simulated generator with segmented graphite, } \\
\text { solid insulation wall, and solid Haynes rod } \\
\text { without } \mathrm{Al}_{2} \mathrm{O}_{3}\end{array}$ \\
\hline 14 & G4A & 1 & $\begin{array}{l}\text { Simulated generator with solid heat accum- } \\
\text { ulator block (graphite), segmented insula- } \\
\text { tion wall and solid Haynes rod with } \mathrm{Al}_{2} \mathrm{O}_{3}\end{array}$ \\
\hline 15 & G4B & 1 & $\begin{array}{l}\text { Same as Type } 14 \text { except designed to be tested } \\
\text { at } 90^{\circ} \text {. }\end{array}$ \\
\hline
\end{tabular}




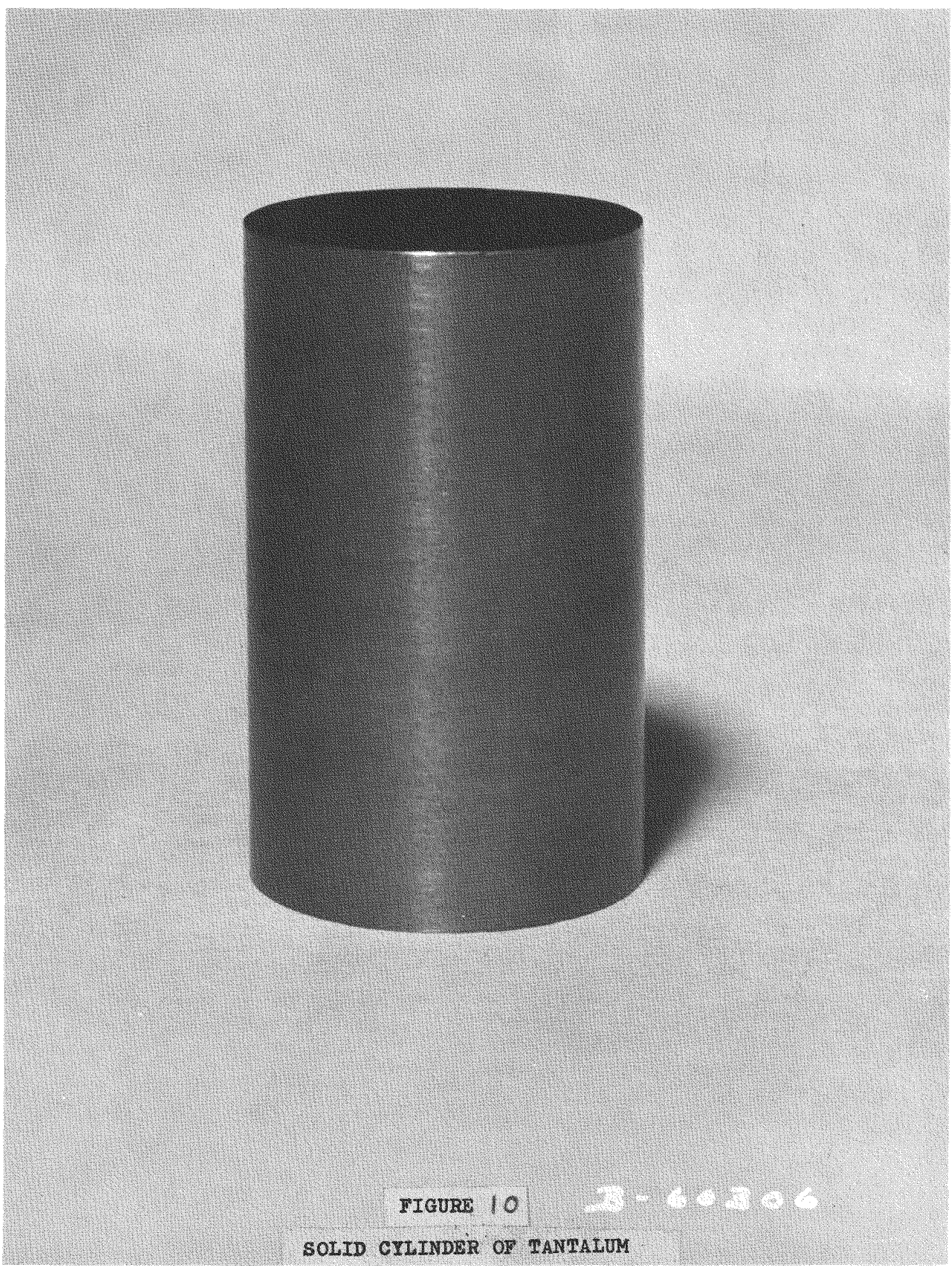




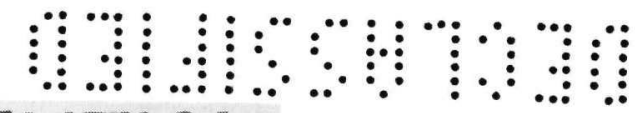
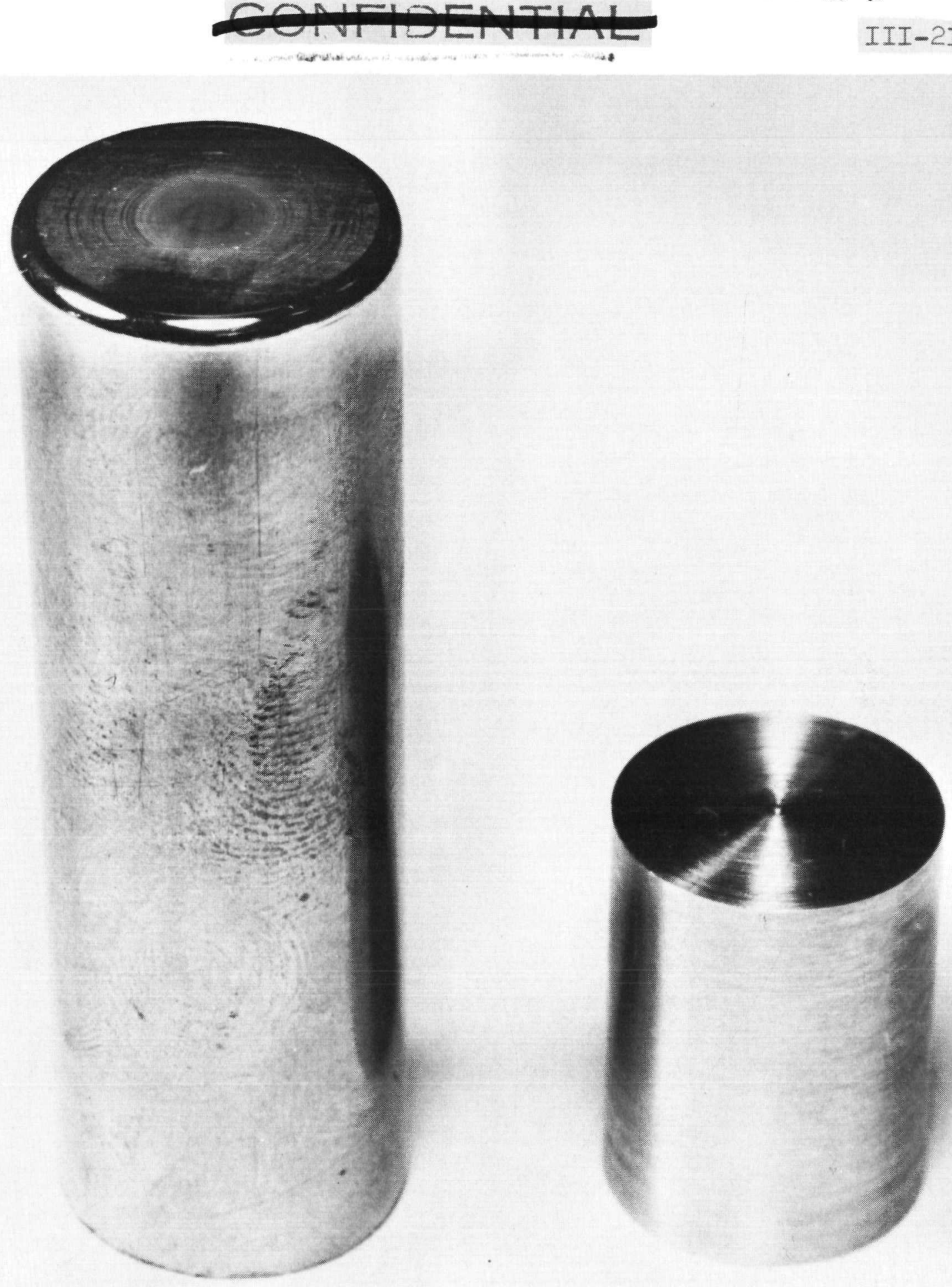

TANTALUM

FUEL SIMULATOR

(COPPER)

FIGURE $\mid$ TANTALUM FUEL LINER (SNAP 9A-IMP)

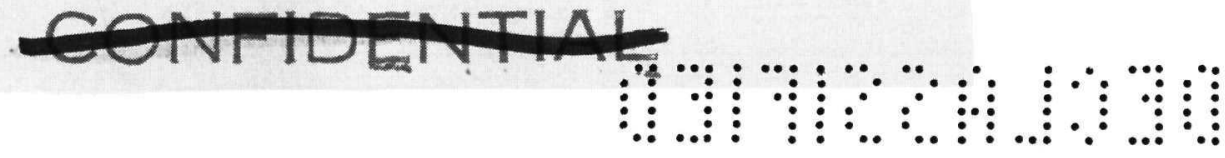


Type 3 was designed to duplicate the full scale SNAP-9A capsule. Types 8 and 9 were designed to duplicate the capsules to be used in the RFD-2 experiment. These capsules are identical except for an 0.187 inch thick coating of aluminum oxide on the ends of Type 9. A11 three specimen types contained a tnatalum liner; however, only Type 3 contained a simulated fuel heat sink of copper. Types 8 and 9 were tested at both $0^{\circ}$ and $90^{\circ}$ to duplicate conditions of the RFD-2 experiment. Figures 12 and 13 show components and assemblies of these fuel capsules.

4. Simulated Generator Specimens

Eight different types of simulated generators were designed for this test program. These models were used to evaluate the interaction of generator components and the overall re-entry behavior of the composite structure. Specific points of interest are:

a. Ablation rate of generator outer magnesium shell

b. Burnup characteristics of Min- $\bar{K}$ (insulation between outer shell and heat accumulator.)

c. Compounds formed by reaction of molten Haynes-25 with graphite and boron nitride.

d. Mechanisms of possible locking and diffusion between molten Haynes-25 and heat accumulator material (graphite and/or boron nitride)

e. Ablation rate and behavior of $\mathrm{Al}_{2} \mathrm{O}_{3}$ on the capsule ends.

f. Effects on break-up of segmented internal elements as opposed to solid elements.

Typical generator assemblies are illustrated in Figures 14, 15, 16 and 17. The Inconel $X$ ring used in 


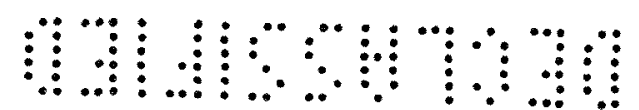

$1+10141$

generator Types 4 and 5 was to hold the segmented boron nitride and graphite heat accumulator block together long enough to cause molten Haynes 25 to flow over the block and force a reaction if there is to be one. The solid heat accumulator blocks Types 14 and 15 were tested to determine the behavior of the simulated fuel capsule material within the block when subjected to the simulated re-entry environment. 

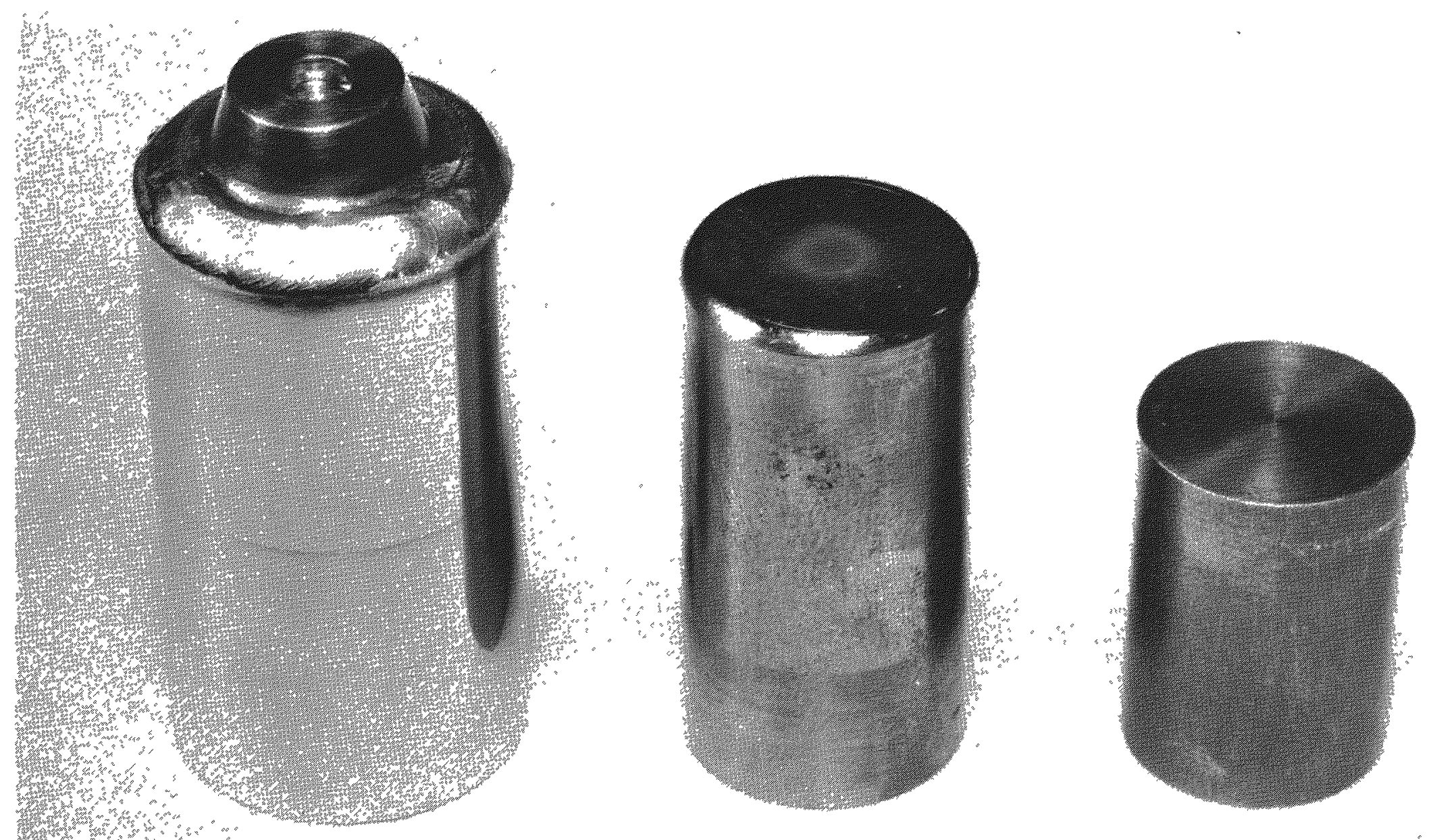

$: \cdots \cdot:$

$\because \because \cdots:$

$\because \because$

$\cdots$

$\therefore$

$\therefore$.

(Y):

di:.:.

$\Rightarrow$

7

te.....:

(2)

1)

$\sqrt{1}$

$\sqrt{2}$

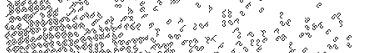

Hents

12)

TANOLTWM EINER

COPPER (FURI SIMULAYOR

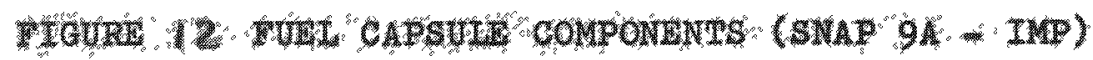



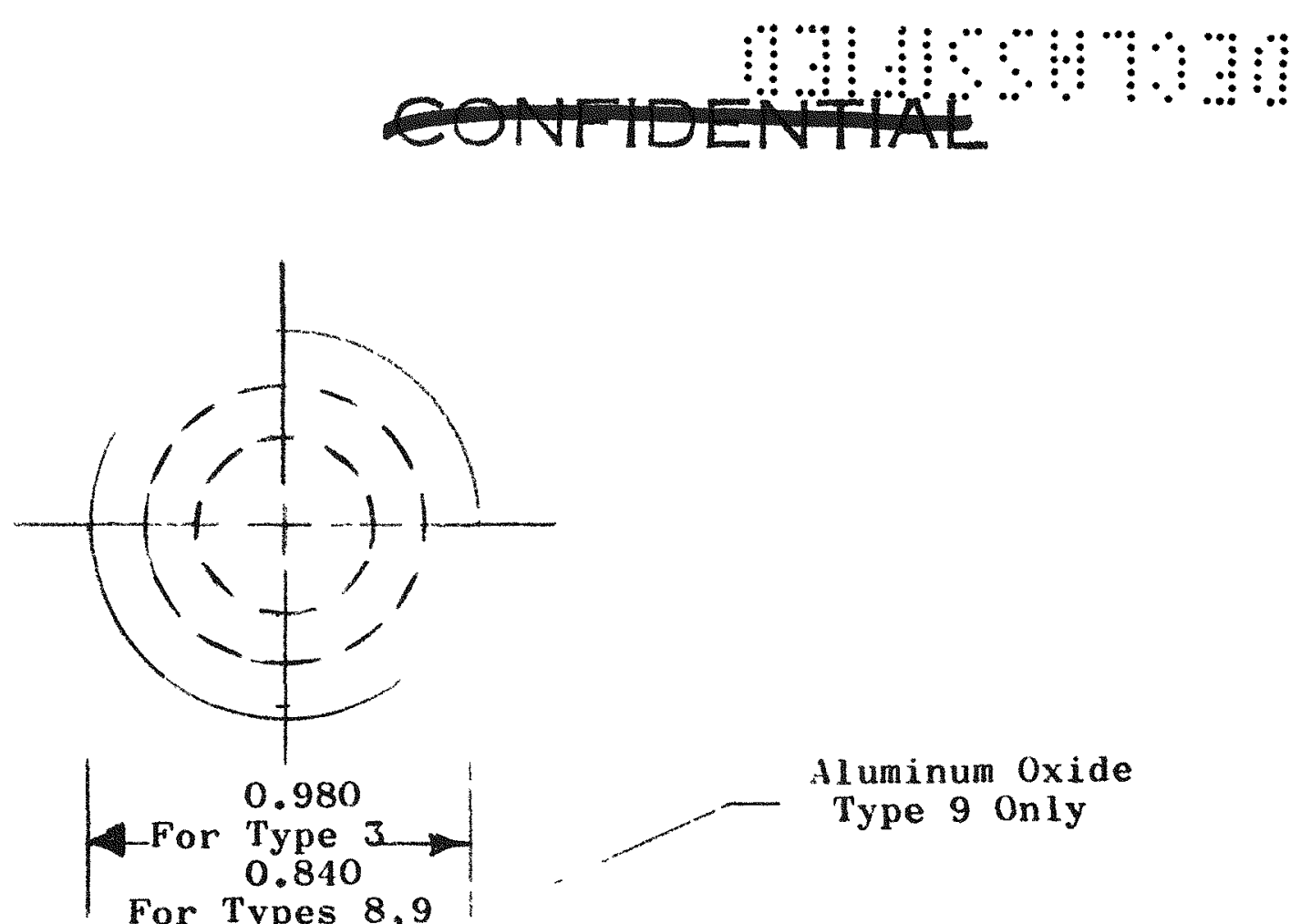

Mluminum Oxide

Type 9 only

For Types 8,9

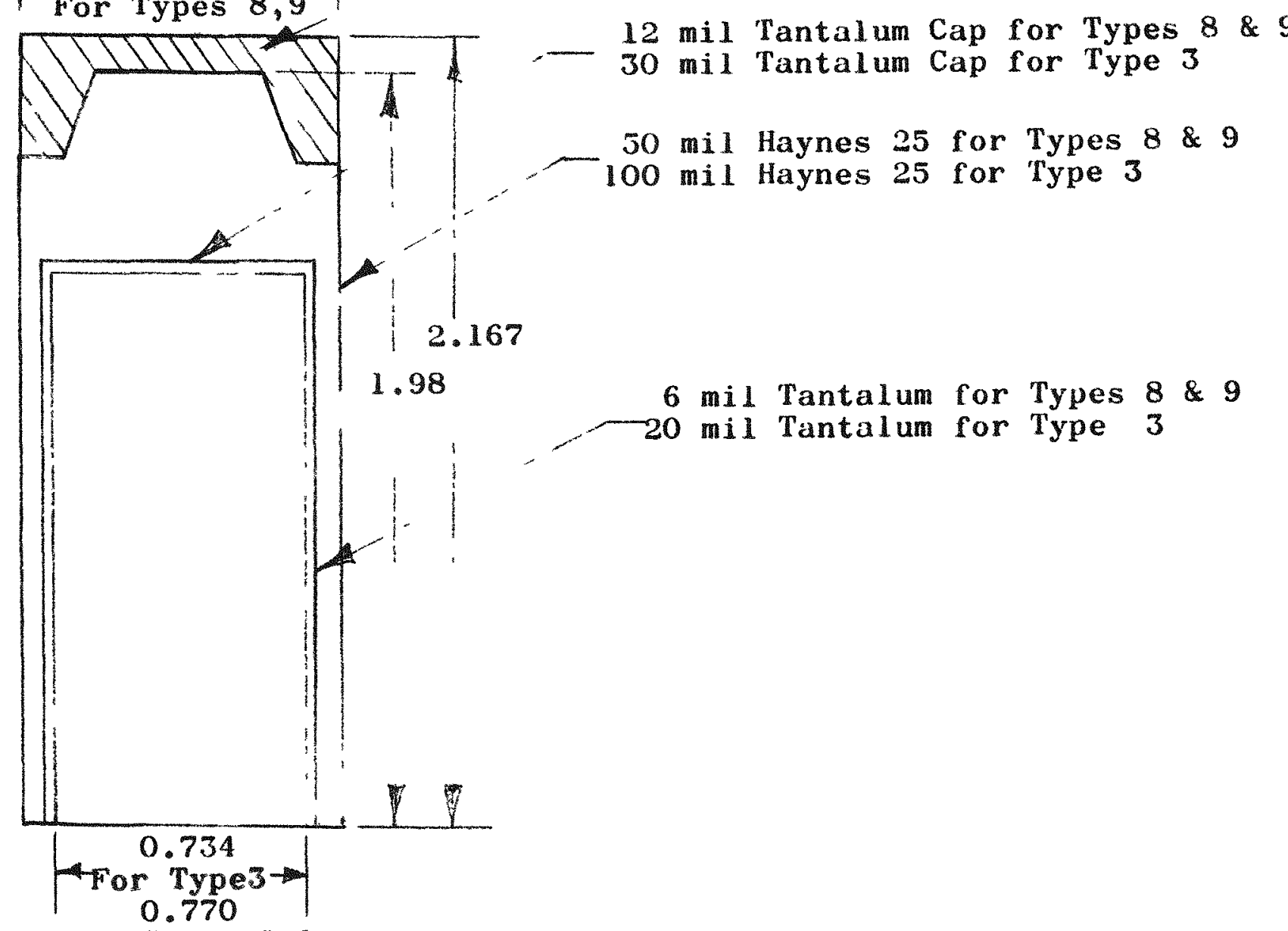

For Types 8,9

FIGURE 13

FUEL CAPSULE TEST SHECIMEN

TYPES $3,8 \& 9$ 


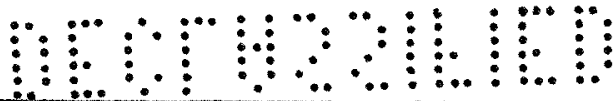

$I I I-50$

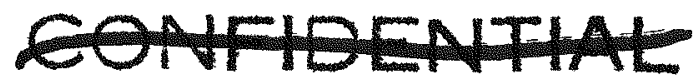

INCONEL $X$ $\left(0.0662^{\prime \prime}\right.$ WIRE )

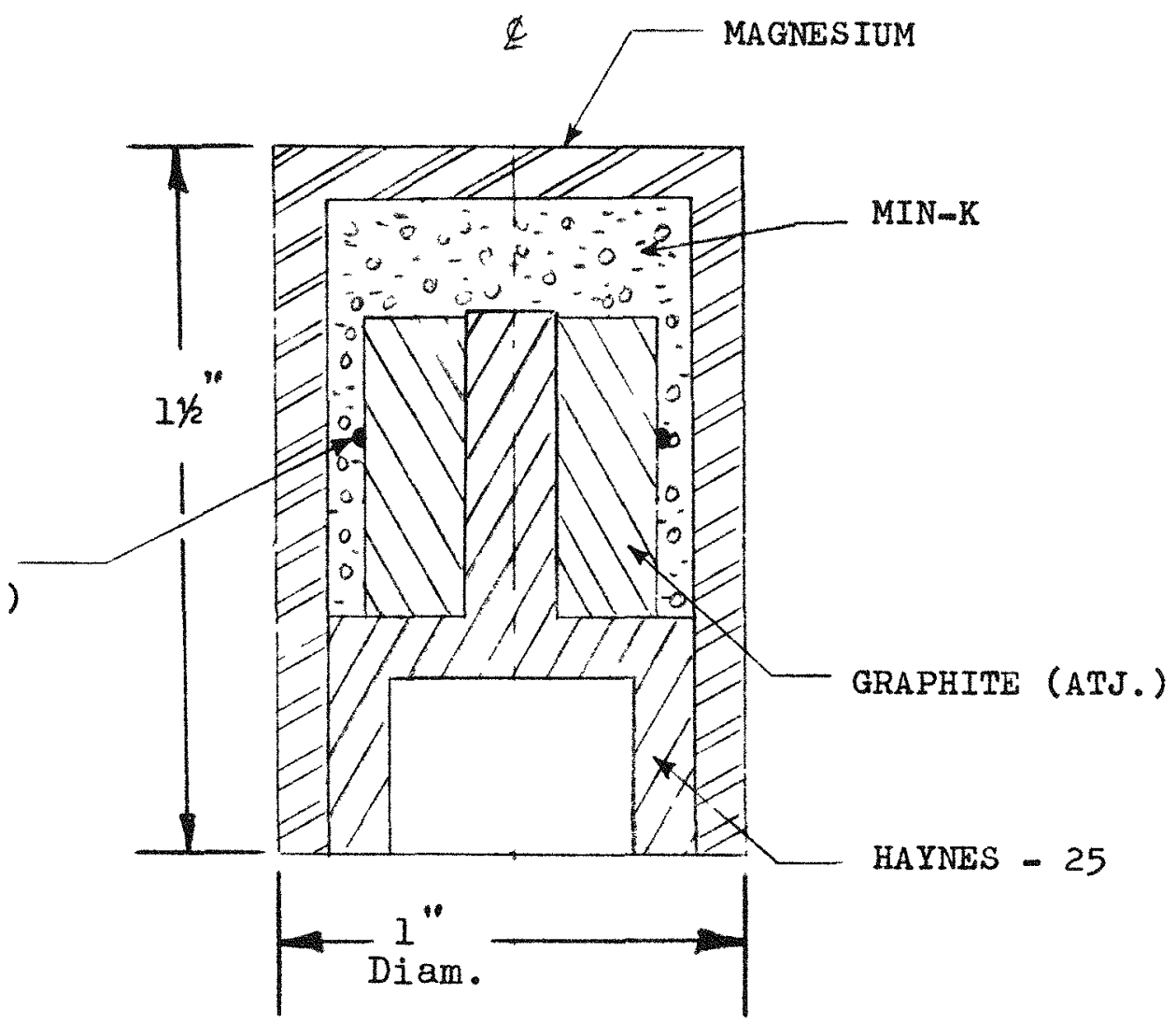

FIGURE 14 GRAPHITE GENERATOR MATERIAL ASSEMBLY 


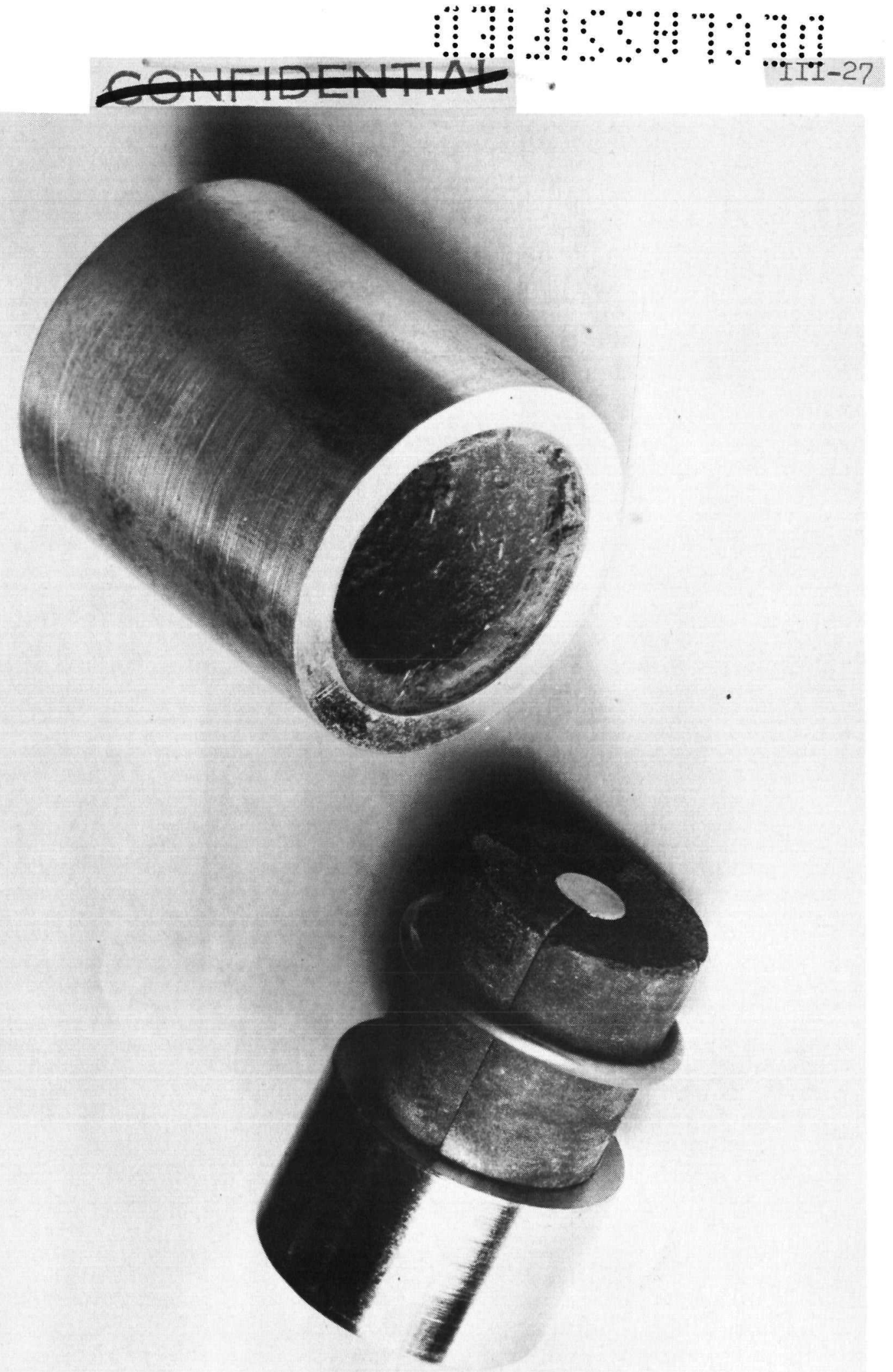

FIGURE 15 GRAPHITE GENERATOR ASSEMBLY

-

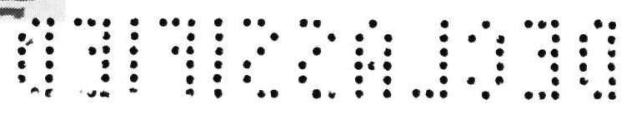



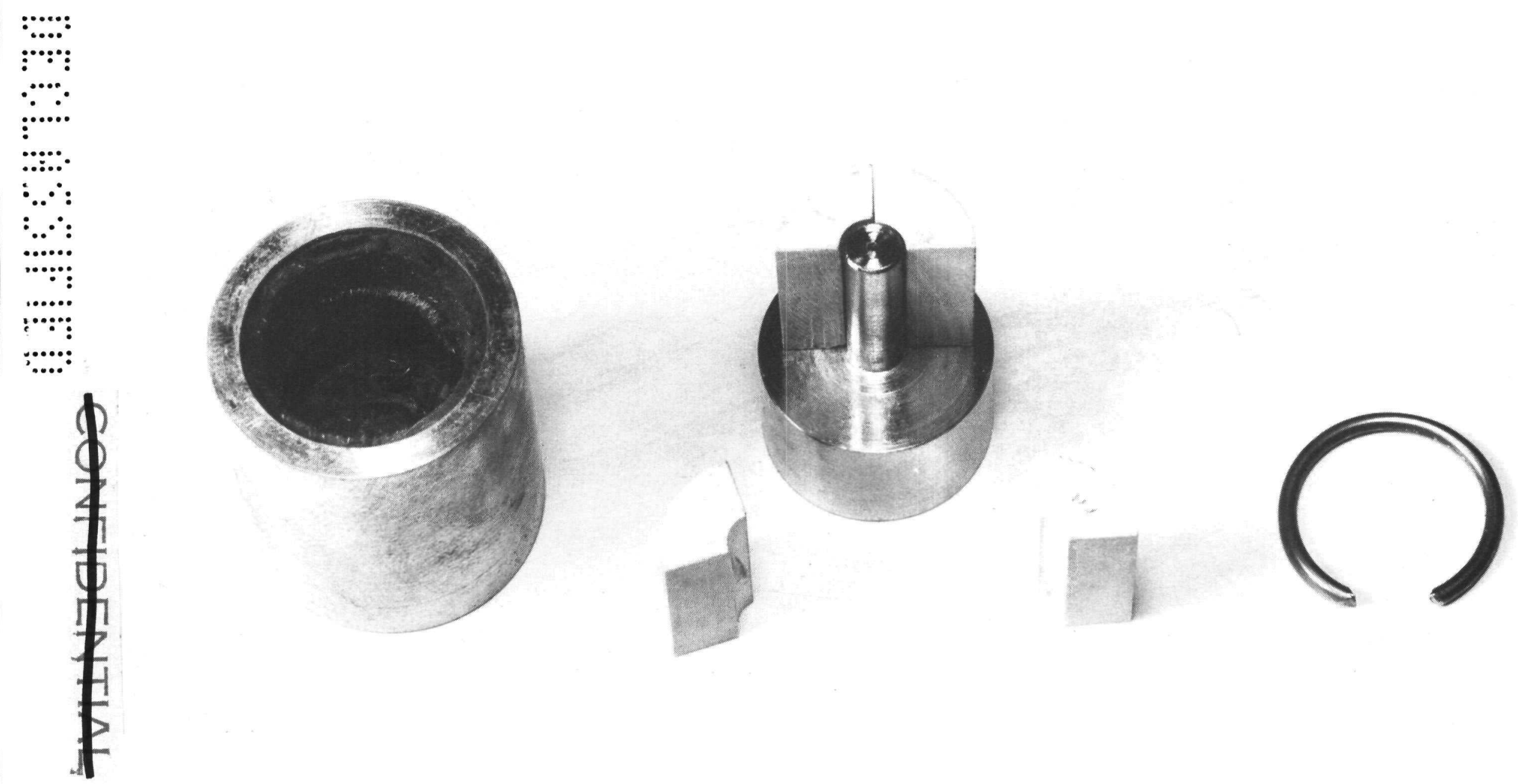

$\ldots$

$\because \because \div$

$\because \because$

$\because \cdots$

$\because$

$\therefore$
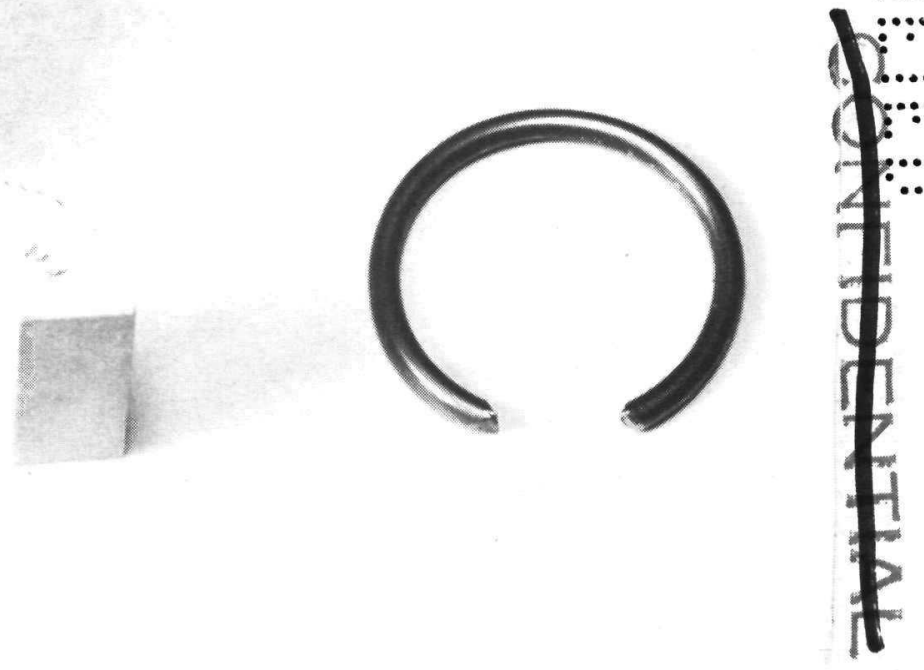

MAGNESIUM

AND

BORON NITRIDE SEGMENTS

AND

INCONEL - X RETAINING RING 


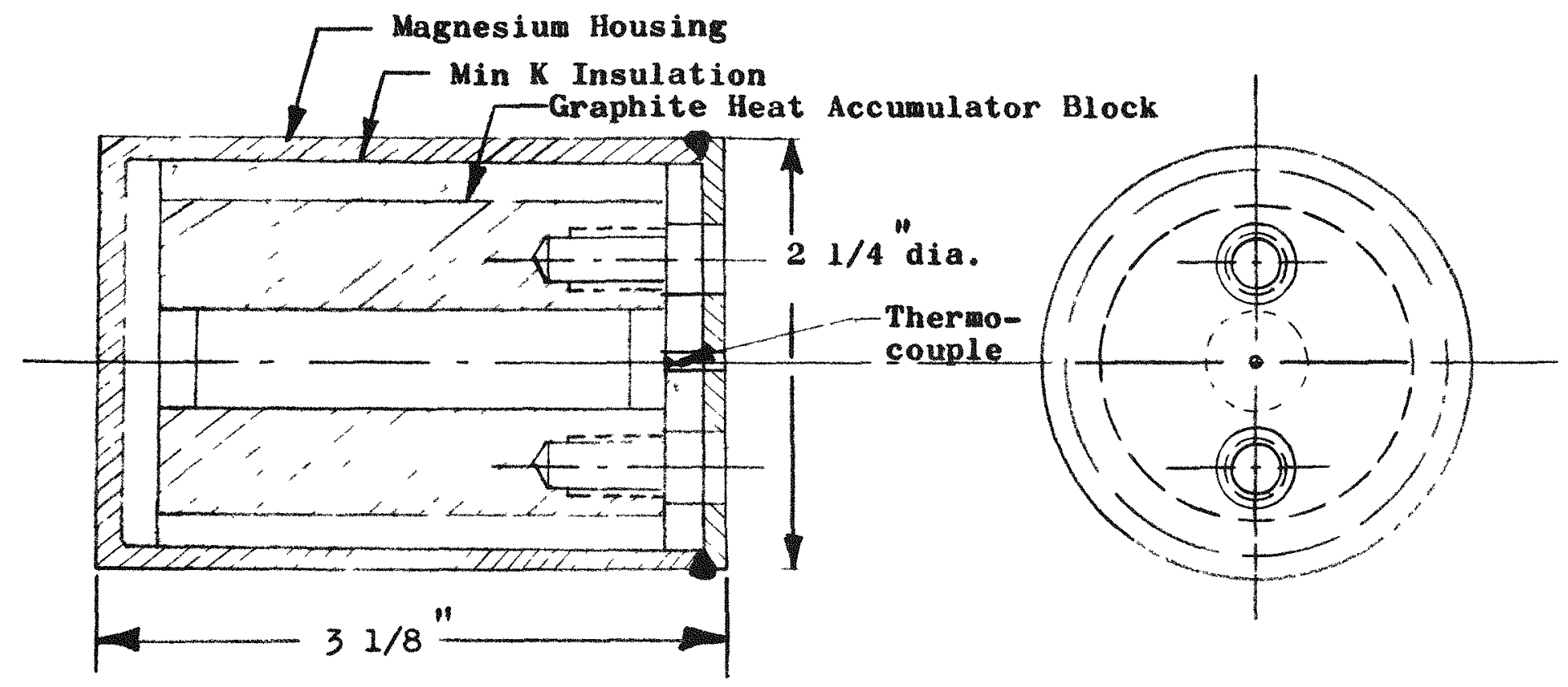

GENERATOR ASSEMBLY DESIGN FOR END-ON EXPOSURE

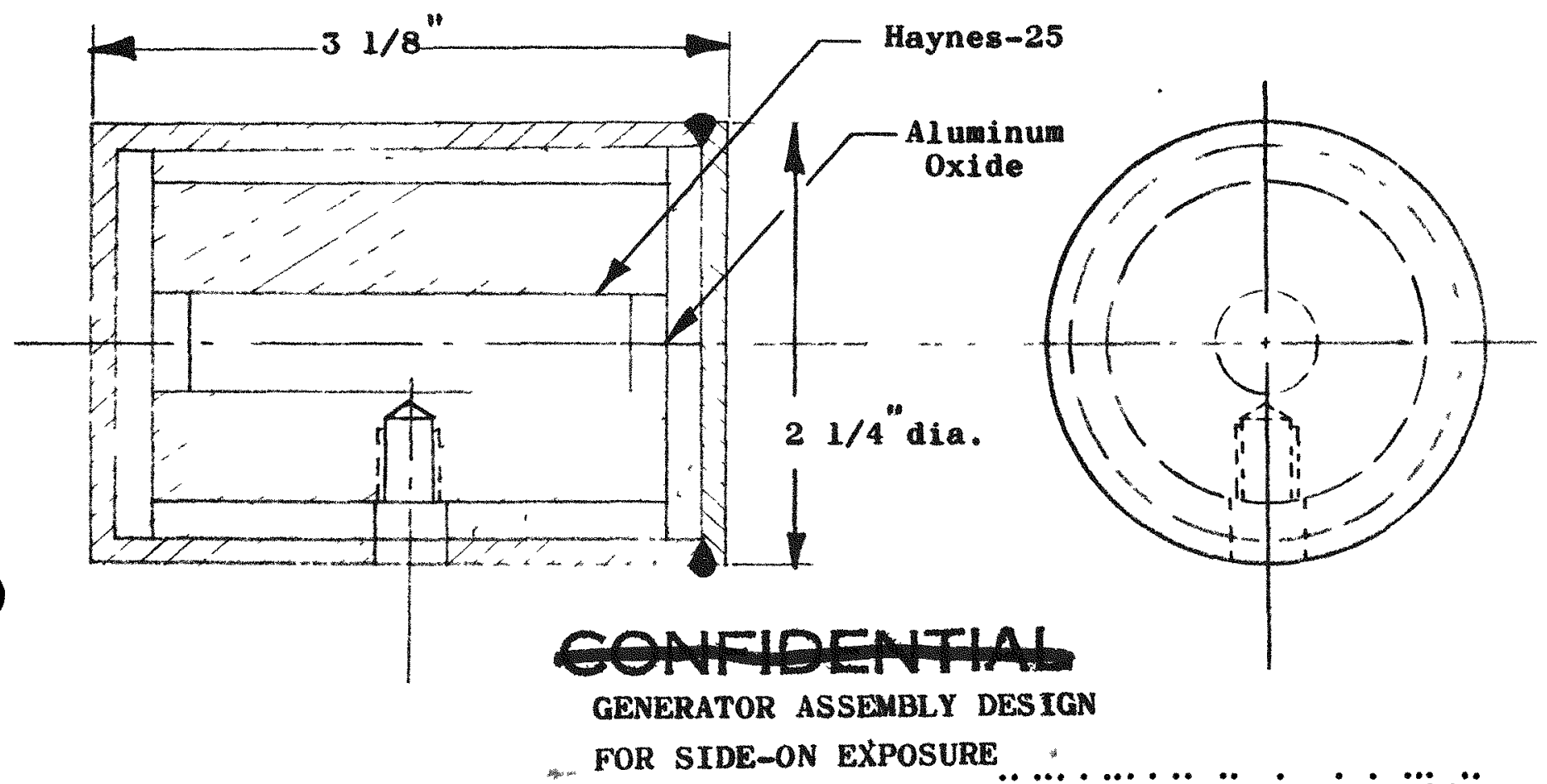

FOR SIDE-ON EXPOSURE 
Data and results for the two series of tests are summarized below.

1. Plasma Arc Data

Data of the plasma arc used to simulate a re-entry environment are given in Table 4.

For the generators, the enthalpy $h_{\mathrm{s}}$ was maintained relatively high and constant, while the heat flux $\stackrel{\circ}{q}_{c w}$ and stagnation pressure $p_{S}$ was varied from low values to high values. The combination of parameters which would most nearly simulate the critical portion of the re-entry trajectory could not be obtained because of the inherent limitation of the plasma arc. The effect of keeping $h_{s}$ constant and varying $q_{c w}$ and $p_{s}$ was to simulate a variable altitude and re-entry body configuration while keeping the velocity constant.

All the simulated parameters for the $T-20$ and $T-6$ liners were varied from low values to high values while, for capsules HT and AHT, $h_{S}$ and ${ }_{q_{c}}$ were maintained relatively constant and $\mathrm{p}_{\mathrm{s}}$ was varied. This latter variation had the effect of simulating a variable altitude for a constant re-entry body configuration and velocity.

\section{Specimen Instrumentation Data}

Model surface brightness temperatures (apparent external surface temperatures) were read with a radiation pyrometer throughout the model exposure period. Internal temperatures for several test specimens were recorded using chromel-alumel thermocouples. Thermocouples were attached to the inner faces of the tantalum capsules on 
GOATHOENITHA

TABLE 4

III $-3 I$

PLASMA ARC TEST PARAMETERS

\begin{tabular}{|c|c|c|c|c|c|c|c|c|c|c|c|c|}
\hline $\begin{array}{c}\text { Specimen } \\
\text { No. }\end{array}$ & $\begin{array}{l}\text { Stagnation } \\
\text { Enthalpy } \\
\mathrm{Hm} \\
(\mathrm{BTU} / 1 \mathrm{~b})\end{array}$ & $\begin{array}{l}\text { Stagnation } \\
\text { Heat Flux } \\
\text { *qcw } \\
\left(\text { BTU } t^{2} \text { sec) }\right.\end{array}$ & $\begin{array}{l}\text { Nitrogen } \\
\text { Mass Flow Rate } \\
\text { MN2 } \\
(1 \mathrm{~b} / \mathrm{sec}) \times 10^{3}\end{array}$ & $\begin{array}{l}\text { Oxyger Mass } \\
\text { Flow Rate } \\
\left.\mathrm{MO}_{2}\right) \times 10^{3} \\
\left(1 \mathrm{~b} / \mathrm{sec}^{2}\right) \times 1\end{array}$ & $\begin{array}{l}\text { Total Mass } \\
\text { Flow Rate } \\
(1 \mathrm{~b} / \mathrm{sec}) \times 10^{3}\end{array}$ & $\begin{array}{l}\text { Stagnation } \\
\text { Pressure } \\
\text { P }_{\mathrm{S}} \\
(\text { Atm })\end{array}$ & $\begin{array}{l}\text { Chamber } \\
\text { Pressure } \\
\text { P }_{\subsetneq} \\
(\text { Atm) }\end{array}$ & $\begin{array}{c}\text { Nozzle Static } \\
\text { Pressure } \\
\text { PN }_{\text {(Atm) }}\end{array}$ & $\begin{array}{l}\text { Nozzle } \\
\text { Exit } \\
\text { Dia. } \\
\text { (in) }\end{array}$ & $\begin{array}{l}\text { Run } \\
\text { Time } \\
(\mathrm{sec})\end{array}$ & $\begin{array}{l}\text { Power } \\
\text { In } \\
(\mathrm{BTU} / \mathrm{sec})\end{array}$ & $\begin{array}{l}\text { Power In } \\
\text { Gas } \\
\text { (BTU/sec) }\end{array}$ \\
\hline$T-1$ & 11,000 & 114.8 & 1.16 & 0.34 & 1.50 & 0.01006 & 0.001070 & 0.001110 & 3.0 & 600 & 93.36 & 15.93 \\
\hline$T-2$ & 5,670 & 43.4 & 1.93 & 0.57 & 2.50 & 0.03231 & 0.001580 & 0.001900 & 1.5 & 290 & 53.05 & 13.44 \\
\hline $\mathrm{T} 20-\mathrm{Cl}$ & 10,400 & 117.4 & 1.16 & 0.34 & 1.50 & 0.00993 & 0.001050 & 0.001090 & 3.0 & 165 & 93.36 & 14.78 \\
\hline $\mathrm{T} 20-\mathrm{C} 2$ & 5.750 & 55.8 & 0.75 & 1.17 & 1.92 & 0.00789 & 0.000920 & 0.000920 & 3.0 & 89 & 50.90 & 10.46 \\
\hline FHT - 1 & 10,700 & 109.8 & 1.16 & 0.34 & 1.50 & 0.00993 & 0.001130 & 0.001130 & 3.0 & 140 & 93.57 & 15.21 \\
\hline$G G 1-1$ & 10,520 & 116.1 & 1.16 & 0.34 & 1.50 & 0.01000 & 0.000990 & 0.000990 & 3.0 & 193 & 93.40 & 14.94 \\
\hline GBI-1 & 10,600 & 123.6 & 1.16 & 0.34 & 1.50 & 0.00993 & 0.001090 & 0.001090 & 3.0 & 189 & 93.22 & 15.07 \\
\hline T2O-IA & 3,495 & 36.0 & 1.54 & 0.46 & 2.00 & 0.02517 & 0.002039 & 0.002039 & 1.5 & 237 & 30.03 & 6.99 \\
\hline$T 6-1 A$ & 3,765 & 36.0 & 1.54 & 0.46 & 2.00 & 0.02585 & 0.002079 & 0.002079 & 1.5 & 16 & 31.00 & 7.53 \\
\hline $\mathrm{T} 20-1 \mathrm{~B}$ & 5,005 & 100.0 & 1.54 & 0.46 & 2.00 & 0.03163 & 0.002355 & 0.002355 & 1.5 & 53 & 46.45 & 10.01 \\
\hline$T 6-1 B$ & 5,025 & 100.0 & 1.54 & 0.46 & 2.00 & 0.03197 & 0.002368 & 0.002368 & 1.5 & 20 & 46.81 & 10.05 \\
\hline $\mathrm{T} 2 \mathrm{O}-2 \mathrm{~A}$ & 6,855 & 192.0 & 1.54 & 0.46 & 2.00 & 0.03912 & 0.002855 & 0.002855 & 1.5 & 8 & 67.02 & 13.91 \\
\hline$T 6-2 A$ & 6,685 & 206.0 & 1.54 & 0.46 & 2.00 & 0.03946 & 0.002868 & 0.002868 & 1.5 & 4 & 67.28 & 13.37 \\
\hline $\mathrm{T} 2 \mathrm{O}-2 \mathrm{~B}$ & 9,425 & 296.0 & 1.54 & 0.46 & 2.00 & 0.04932 & 0.003605 & 0.003605 & 1.5 & 4 & 95.41 & 18.85 \\
\hline $\mathrm{HT}-3$ & 7,720 & 162.0 & 0.77 & 0.23 & 1.00 & 0.02279 & 0.001670 & 0.001670 & 1.5 & 9 & 49.91 & 7.72 \\
\hline $\mathrm{HT}-2$ & 8,335 & 326.0 & 1.54 & 0.46 & 2.00 & 0.04252 & 0.003026 & 0.003026 & 1.5 & 29 & 81.80 & 16.67 \\
\hline $\mathrm{AHM}_{\mathrm{D}}-1$ & 8,225 & 310.0 & 1.54 & 0.46 & 2.00 & 0.04082 & 0.002894 & 0.002894 & 1.5 & 277 & 77.44 & 16.45 \\
\hline$A H T-2$ & 7,780 & 239.0 & 0.77 & 0.23 & 1.00 & 0.02211 & 0.001710 & 0.001710 & 1.5 & 277 & 51.06 & 7.78 \\
\hline A.Hm -4 & 8,110 & 167.0 & 0.77 & 0.23 & 1.00 & 0.02313 & 0.001710 & 0.001710 & 1.5 & 92 & 51.18 & 8.11 \\
\hline $\mathrm{AHT}-3$ & 8,215 & 310.0 & 1.54 & 0.46 & 2.00 & 0.04116 & 0.002927 & 0.002927 & 1.5 & 36 & 77.44 & 16.55 \\
\hline
\end{tabular}


III -32

CONFIDEANTAL

TABLE 4 (CONTINUED)

PLASMA ARC TEST PARAMETERS

\begin{tabular}{|c|c|c|c|c|c|c|c|c|c|c|c|c|}
\hline $\begin{array}{c}\text { Specimen } \\
\text { No. }\end{array}$ & $\begin{array}{c}\text { Stagnation } \\
\text { Enthalpy } \\
H_{T} \\
(B T U / 1 b)\end{array}$ & $\begin{array}{l}\text { Stagnation } \\
\text { Heat Flux } \\
\text { qqCw } \\
\left(\text { BTU } / \text { ft }^{2} \text { sec }\right)\end{array}$ & $\begin{array}{l}\text { Nitrogen } \\
\text { Mass Flow Rate } \\
\text { MN2 } \\
(1 \mathrm{~b} / \mathrm{sec}) \times 10^{3}\end{array}$ & $\begin{array}{l}\text { Oxygen Mass } \\
\text { Flow Rate } \\
\text { Mu2 } \\
(1 \mathrm{~b} / \mathrm{sec}) \times 10^{3}\end{array}$ & $\begin{array}{l}\text { Total Mass } \\
\text { Flow Rate } \\
\mathbb{M}_{\mathrm{T}} \\
(1 \mathrm{~b} / \mathrm{sec}) \times 10^{3}\end{array}$ & $\begin{array}{c}\text { Stagnation } \\
\text { Pressure } \\
\text { Ps } \\
\text { (Atm) }\end{array}$ & $\begin{array}{l}\text { Chamber } \\
\text { Pressure } \\
\text { P }_{\text {(Atm }}\end{array}$ & $\begin{array}{c}\text { Nozzle Static } \\
\text { Pressure } \\
\text { PN } \\
(A t m)\end{array}$ & $\begin{array}{l}\text { Nozzle } \\
\text { Exit } \\
\text { Dia. } \\
\text { (in) }\end{array}$ & $\begin{array}{l}\text { Run } \\
\text { Time } \\
(\mathrm{sec})\end{array}$ & $\begin{array}{l}\text { Power } \\
\text { In } \\
(\mathrm{BTU} / \mathrm{sec})\end{array}$ & $\begin{array}{l}\text { Power In } \\
\text { Gas } \\
\text { (BTU/sec) }\end{array}$ \\
\hline $\mathrm{HT}-4$ & 8,210 & 162.0 & 0.077 & 0.023 & 1.00 & 0.02279 & 0.001710 & 0.001710 & 1.5 & 27 & 50.93 & 8.21 \\
\hline$G I A-4$ & 9,209 & 176.0 & 2.502 & 0.748 & 3.25 & 0.01320 & 0.001776 & 0.001776 & 3.0 & 300 & 101.05 & 29.93 \\
\hline GIB -4 & 9,277 & 142.0 & 2.502 & 0.748 & 3.25 & 0.01326 & 0.001829 & 0.001829 & 3.0 & 66 & 100.89 & 30.15 \\
\hline$G 1 A-3$ & 9,252 & 80.0 & 2.502 & 0.748 & 3.25 & 0.01320 & 0.001789 & 0.001789 & 3.0 & 200 & 100.89 & 30.07 \\
\hline G2-1 & 9,194 & 80.0 & 2.502 & 0.748 & 3.25 & 0.01333 & 0.001763 & 0.001763 & 3.0 & 300 & 100.56 & 29.88 \\
\hline$G 4 A-1$ & 8,892 & 76.0 & 2.502 & 0.748 & 3.25 & 0.01497 & 0.001737 & 0.001737 & 3.0 & 300 & 98.23 & 28.90 \\
\hline G3-I & 9,065 & 76.0 & 2.502 & 0.748 & 3.25 & 0.01429 & 0.001710 & 0.001710 & 3.0 & 300 & 98.39 & 29.46 \\
\hline$G \perp B-3$ & 8,923 & 135.0 & 2.502 & 0.748 & 3.25 & 0.01429 & 0.001737 & 0.001737 & 3.0 & 71 & 98.54 & 29.00 \\
\hline$G 4 B-1$ & 9,811 & 128.0 & 2.502 & 0.748 & 3.25 & 0.01395 & 0.001750 & 0.001750 & 3.0 & 400 & 98.70 & 28.96 \\
\hline$G 1 A-1$ & 8,944 & 56.0 & 0.962 & 0.288 & 1.25 & 0.00748 & 0.000842 & 0.000842 & 3.0 & 300 & 83.95 & 11.18 \\
\hline GIB-1 & 9,080 & 91.0 & 0.962 & 0.288 & 1.25 & 0.00748 & 0.000842 & 0.000842 & 3.0 & 300 & 83.78 & 11.35 \\
\hline GIB -2 & 9,291 & 142.0 & 1.348 & 0.402 & 1.75 & 0.01068 & 0.001138 & 0.000842 & 3.0 & 300 & 78.87 & 16.26 \\
\hline$G 1 A-2$ & 8,994 & 71.0 & 1.348 & 0.402 & 1.75 & 0.01020 & 0.001079 & 0.001079 & 3.0 & 300 & 71.07 & 15.74 \\
\hline
\end{tabular}


specimen Type 9; while, on specimen Types $10,12,13$, and 14, the thermocouple was attached to the far end of the simulated capsule oriented to the front of the stream. This latter thermocouple was attached to the aluminum oxide disk at the end of the capsule.

The model surface temperature ( $T_{T}$ ) corrected for the surface emissivity $(\epsilon)$ and internal temperatures are given in Figures 18 through 37. Corrected surface temperatures were found from the surface apparent temperatures $\left(T_{B}\right)$ by the following equation:

$$
T_{T}=\sqrt[4]{\frac{T_{B}{ }^{4}}{\varepsilon}}
$$

Emissivity values used in this analyses are as follows:

(1) Magnesium -0.2

(2) Min-K $\quad-0.8$

(3) Graphite -0.9

(4) Boron Nitride -0.44

(5) Haynes-25 -0.8

(6) Aluminum Oxide -0.34

3. Specimen Analyses

The characteristics exhibited in the plasma by each model was recorded on film. By this means, it was possible to obtain data on material ablation, oxidation, flow characteristics, model break-up, and component interactions. Further, each specimen was analyzed metallographically using X-ray diffraction and emission spectroscopy techniques to obtain material interaction data. 
FIGURE 18

TANTALUM OXIDATION MODEL (TYPE T)

SURFACE TEMPERATURE

$\because \because$

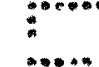

:...:"

$\therefore \therefore$

$\because .$.

$\ldots$

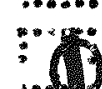



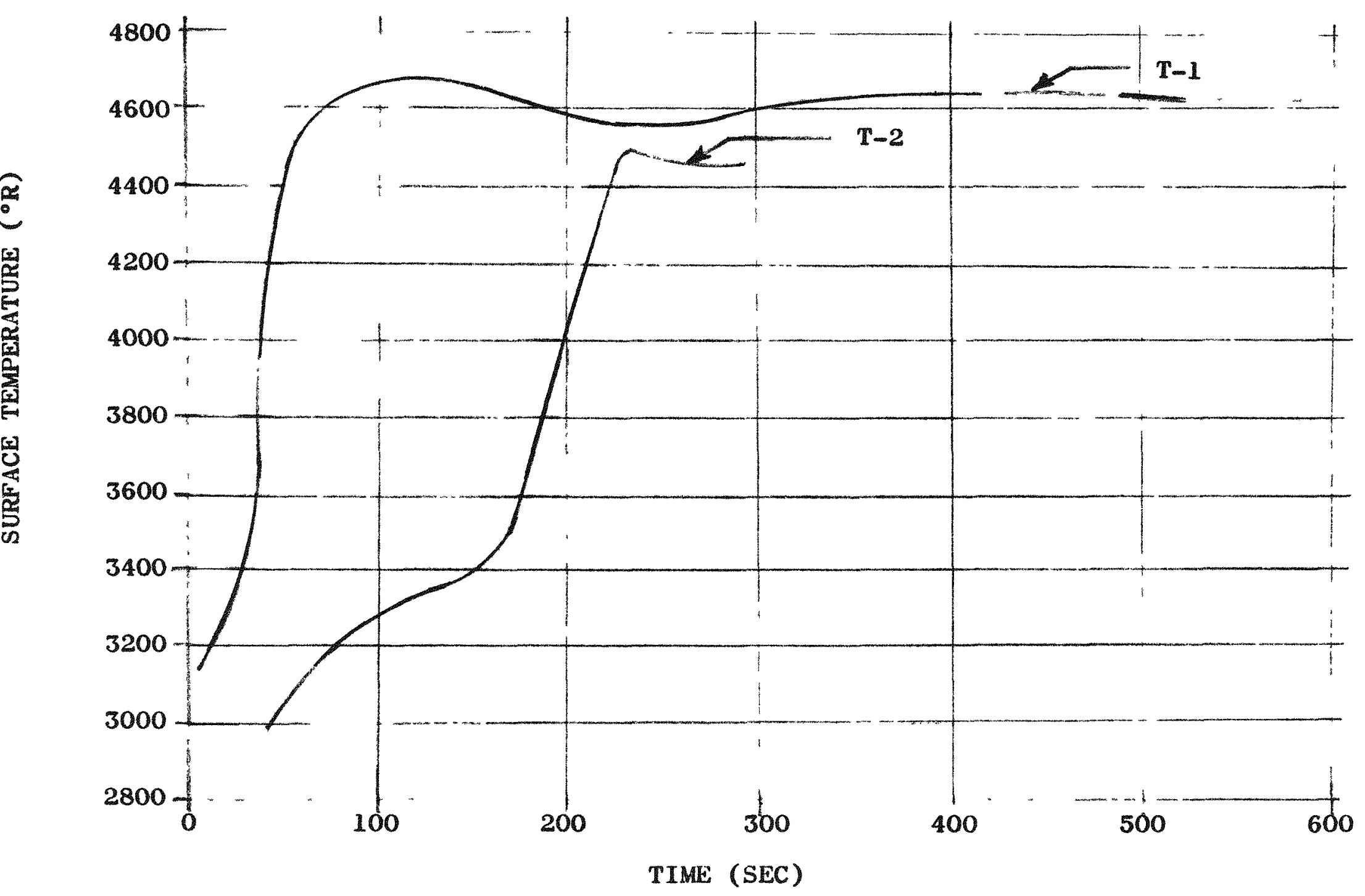

$\frac{9}{2}$ 
FIGURE 19

SURFACE TEMPERATURES

SPEC IMENT TYPES $2,3,4$ and 5

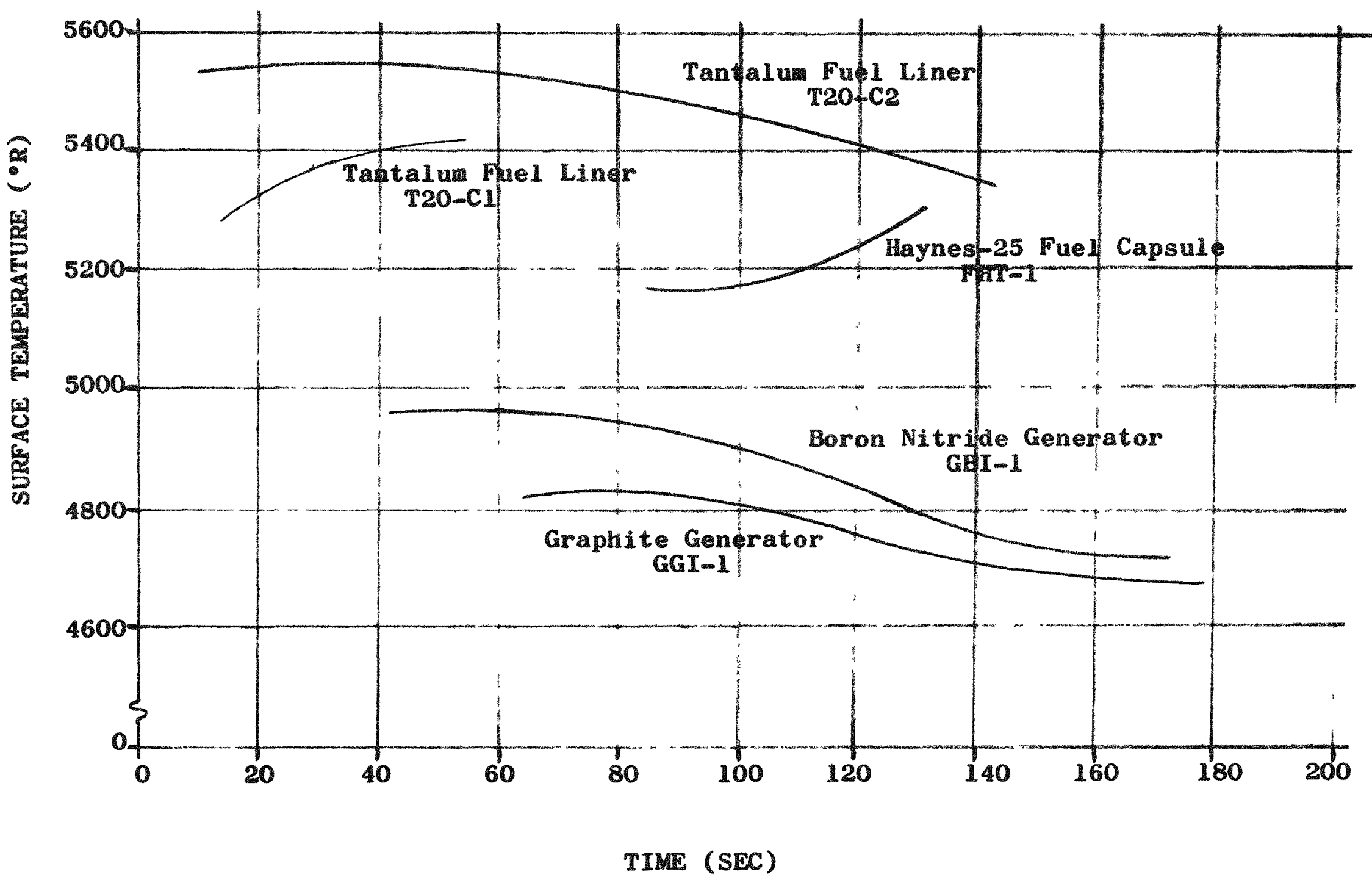

¿.....

$\because \cdots$ $\because \because:$ $\therefore$

.....:

$\therefore \therefore$

$\vdots . . .$.

$\therefore \ldots$

TIME (SEC) 

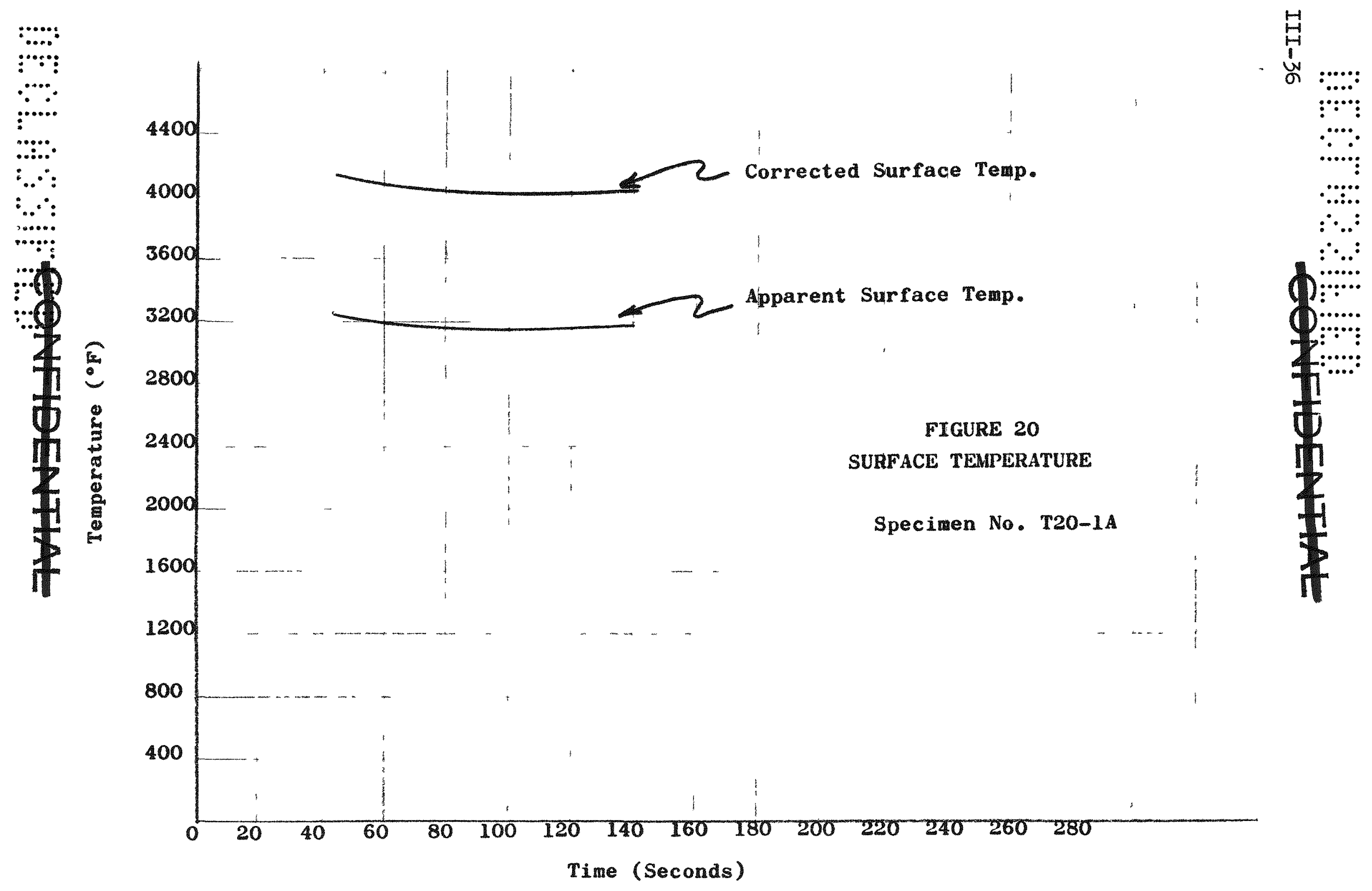


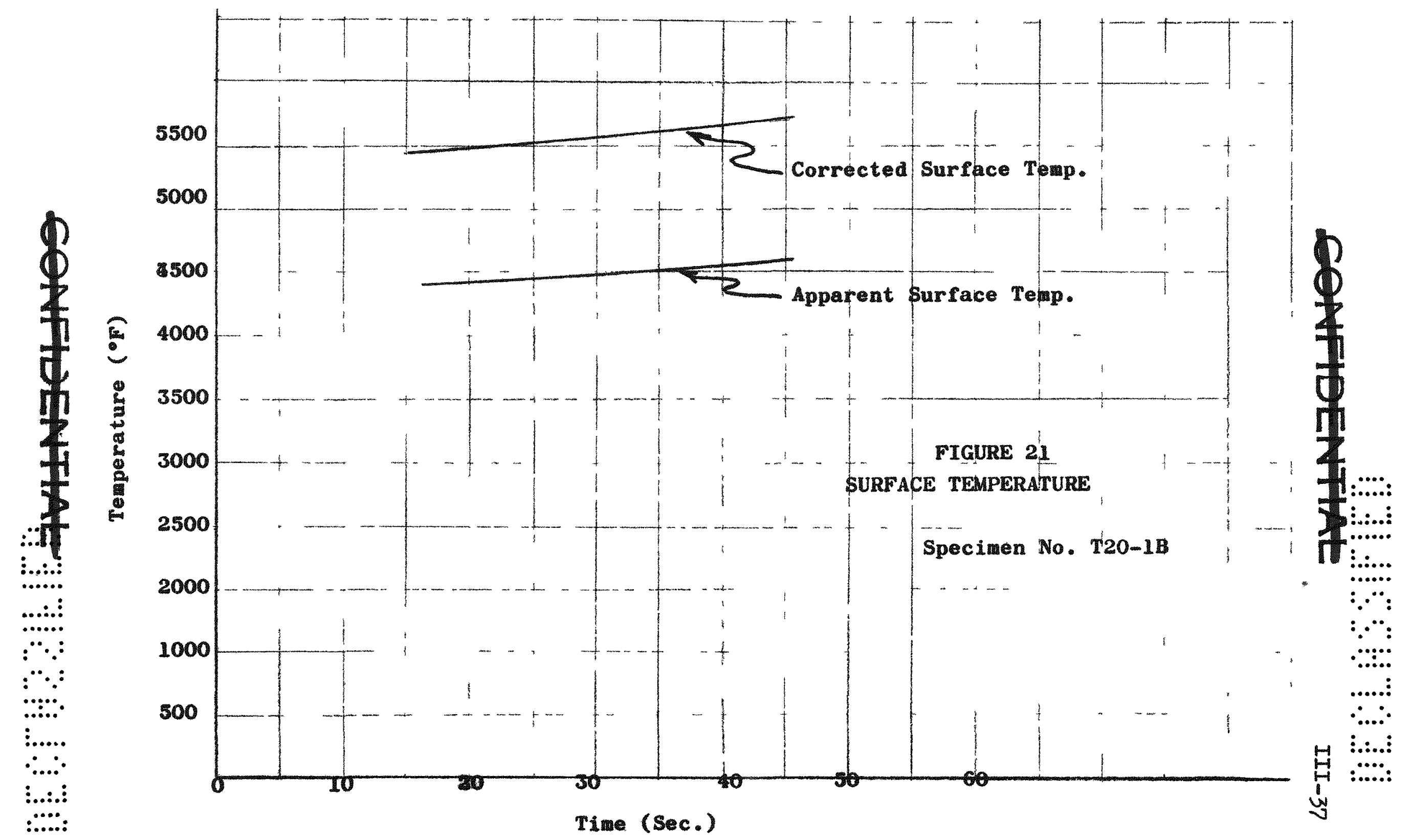




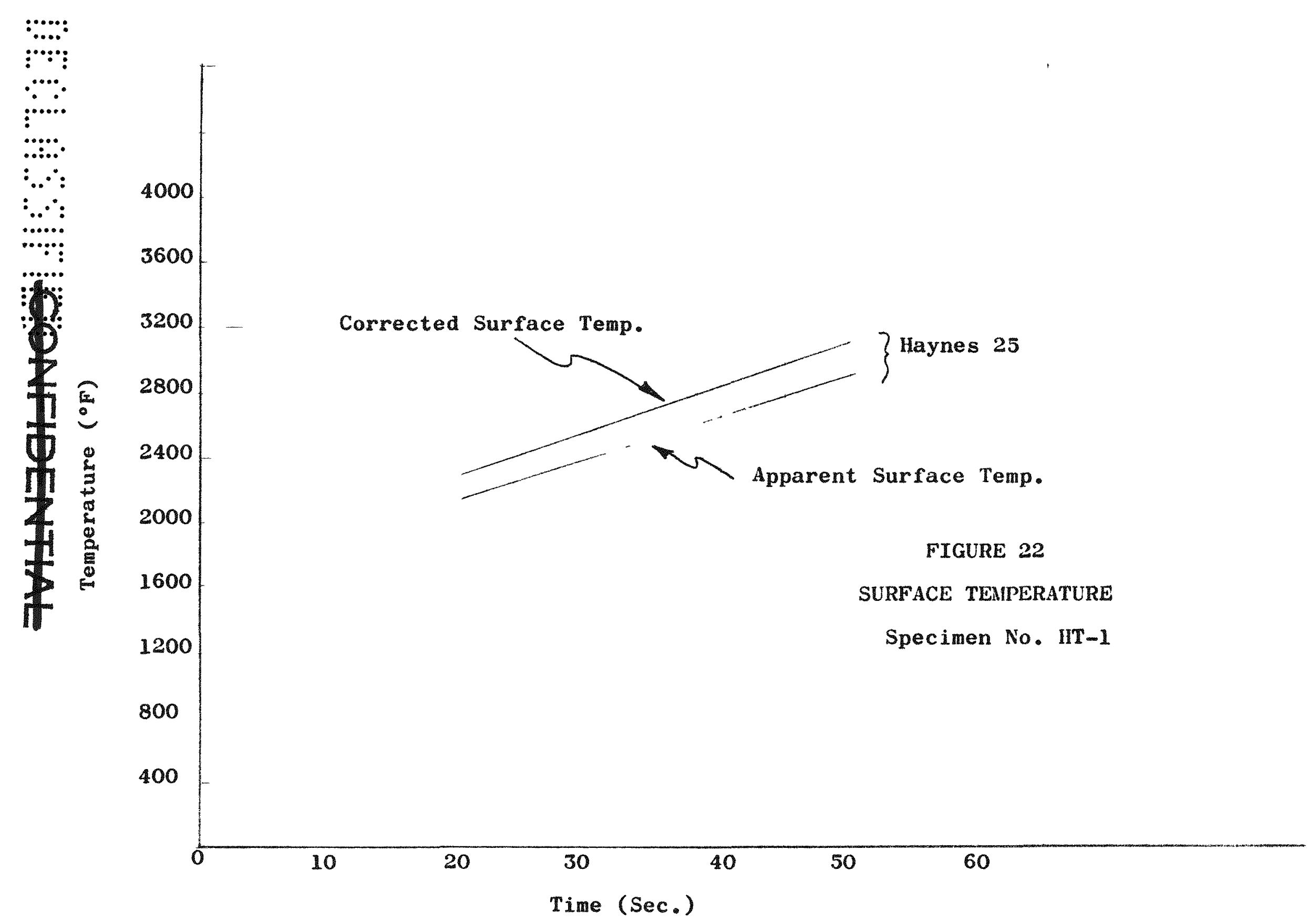




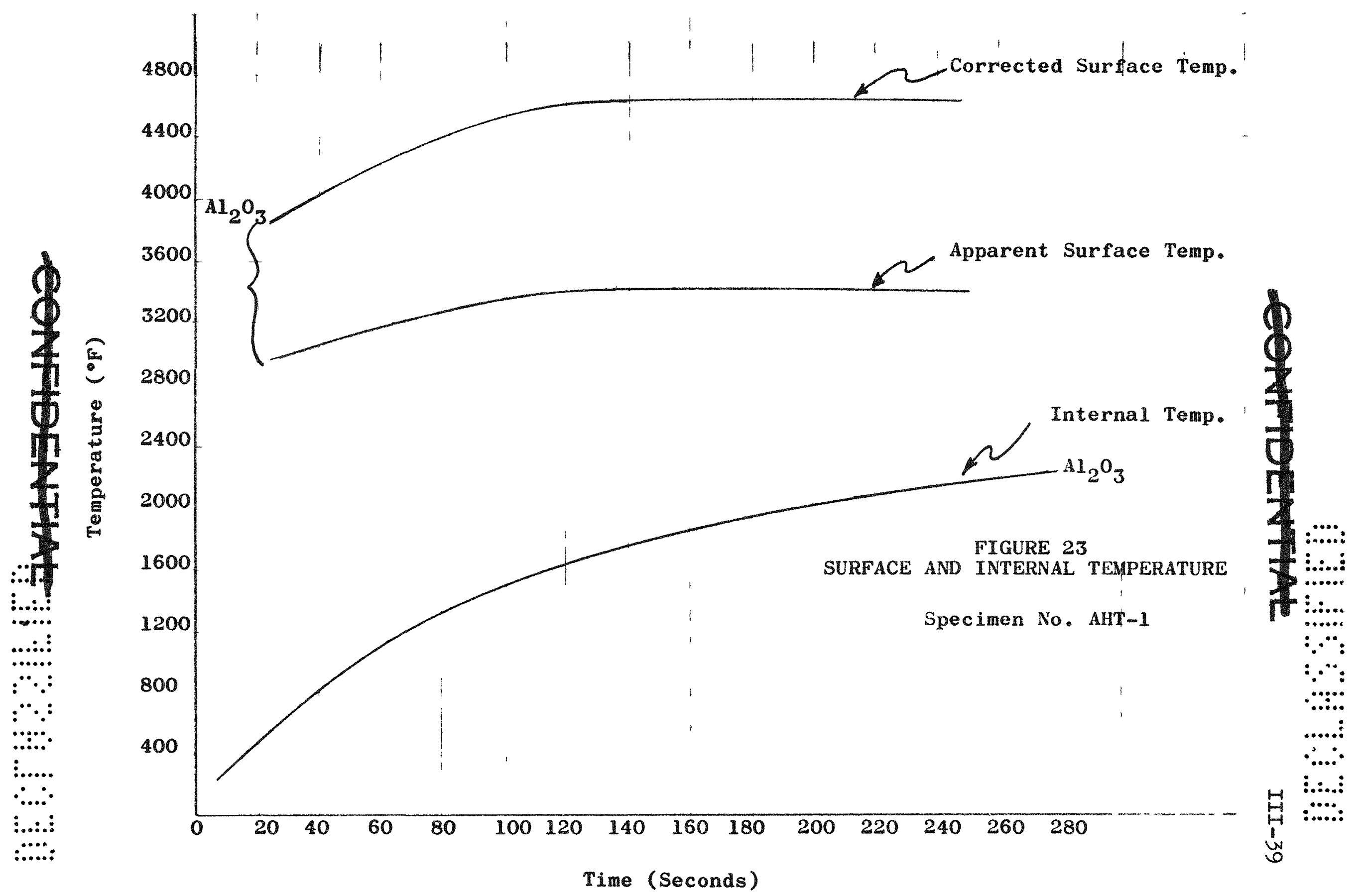




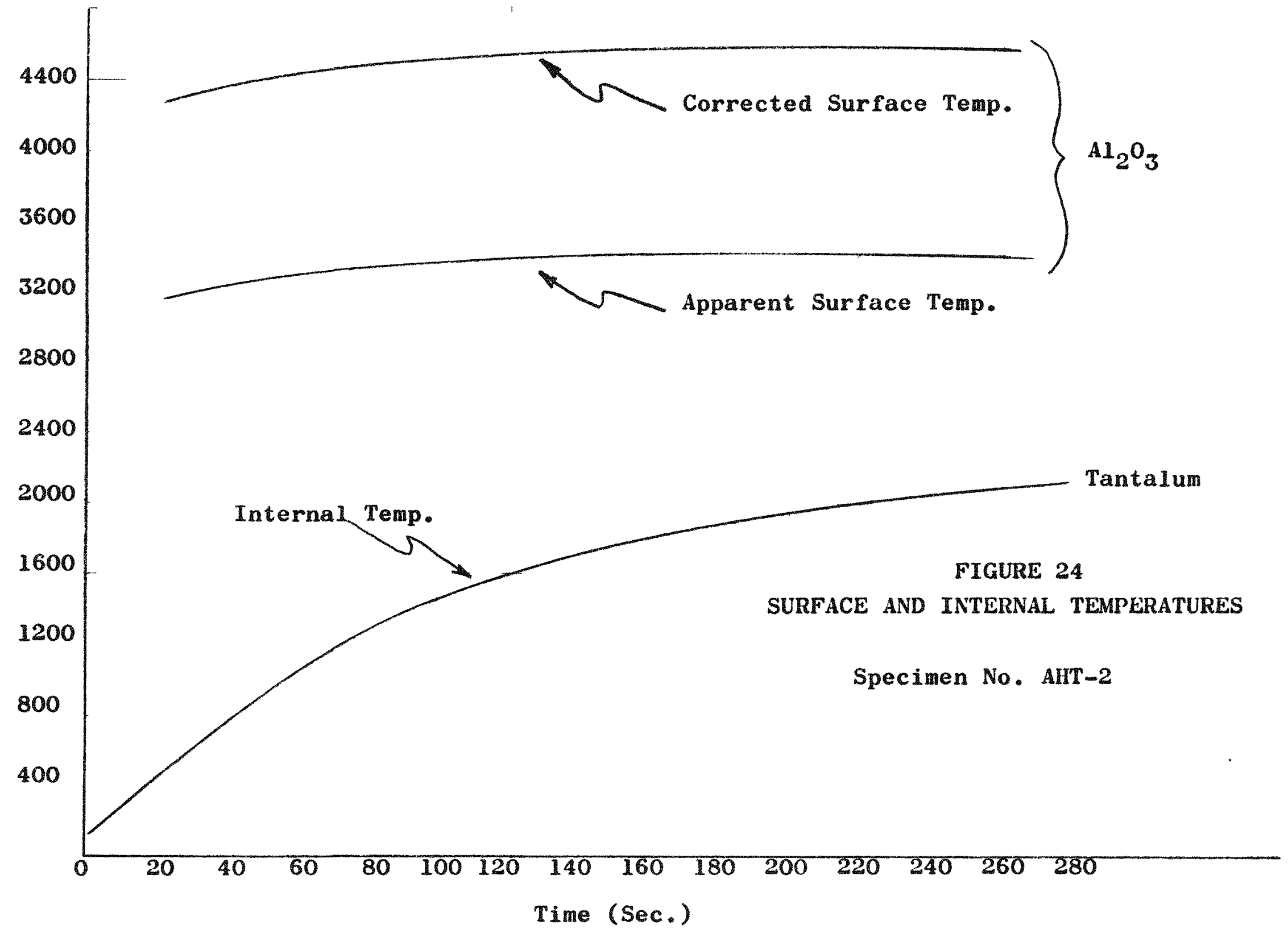



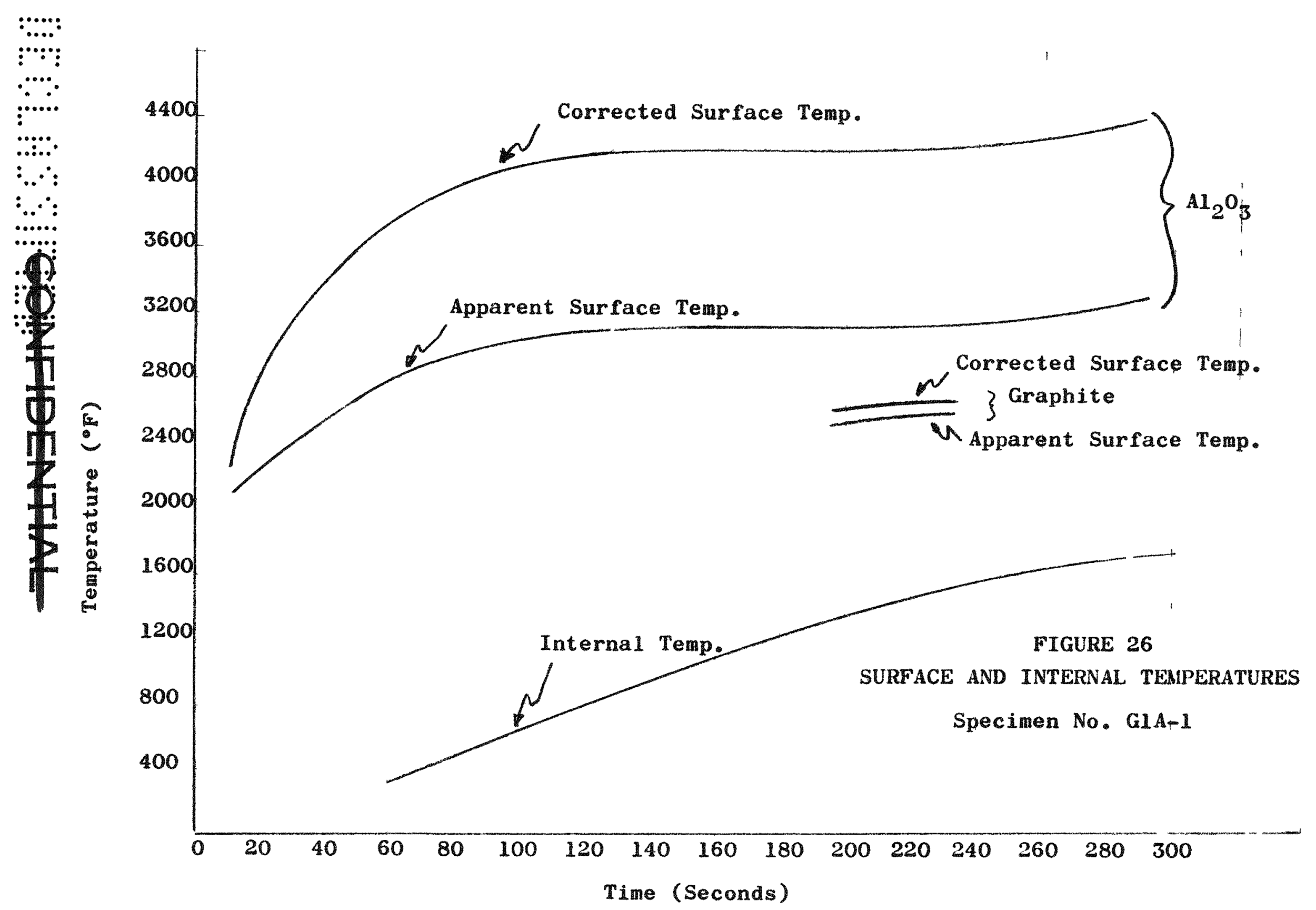

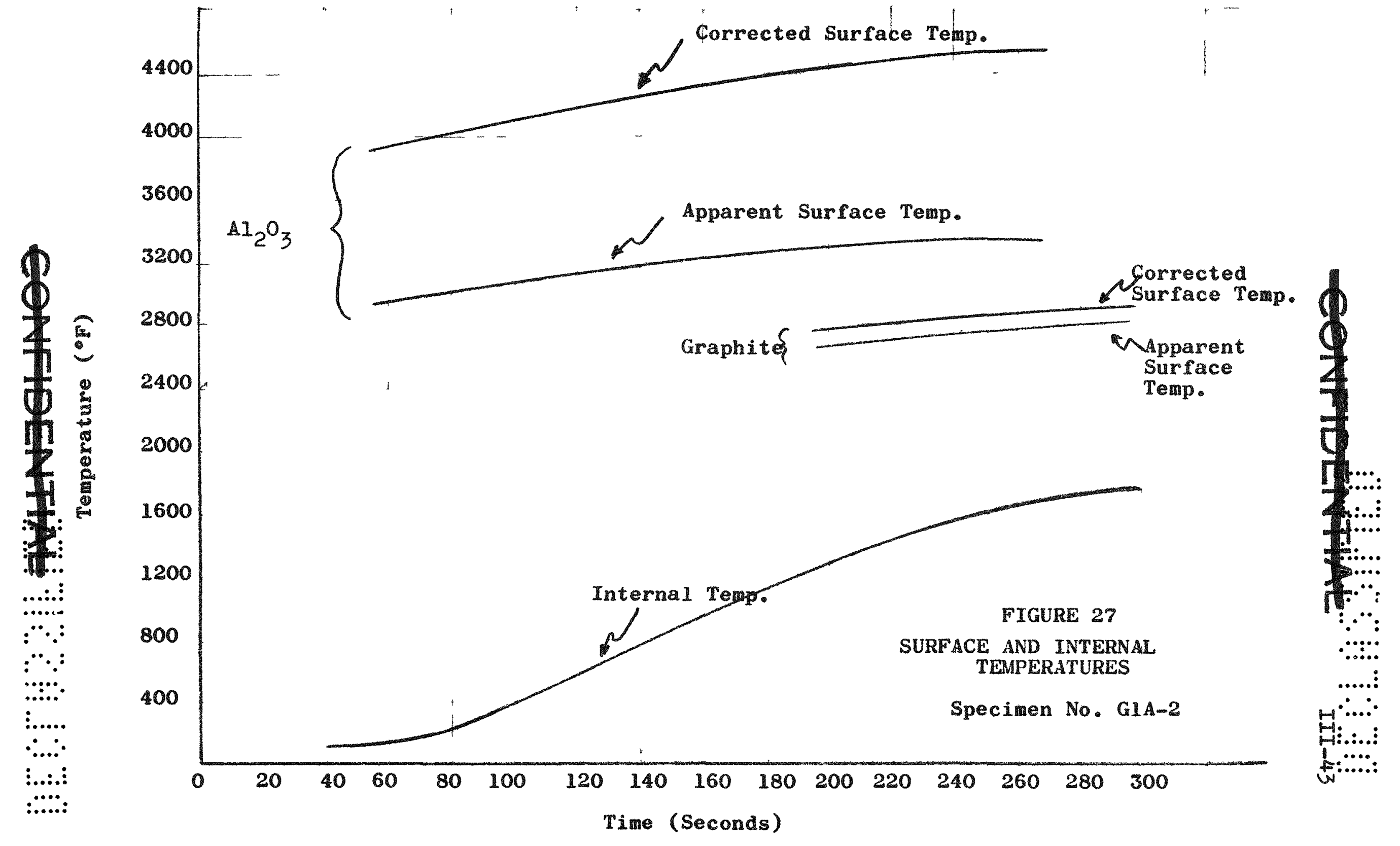


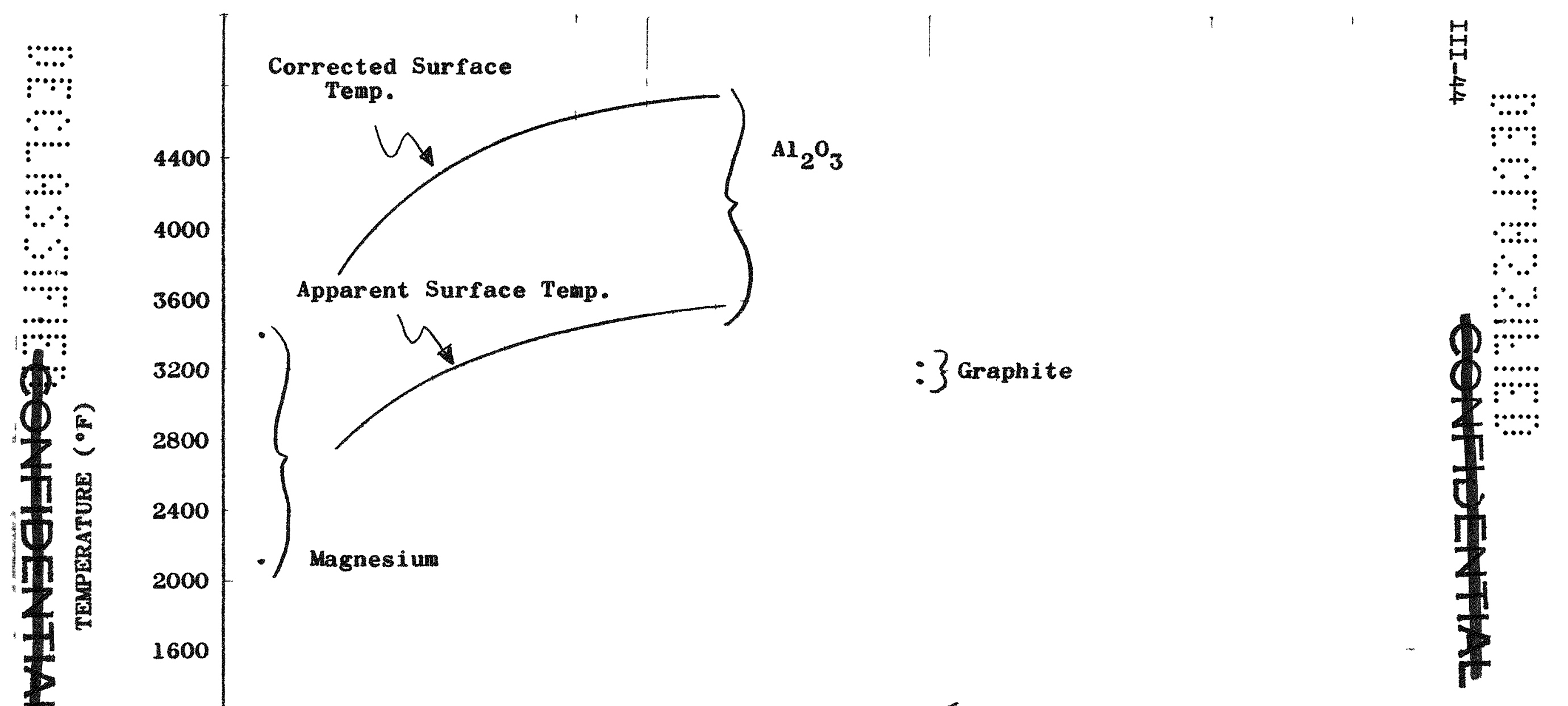

FIGURE 28 SURFACE AND INTERNAL TEMPERATURES Specimen No. GIA-3

TIME (SECONDS) 


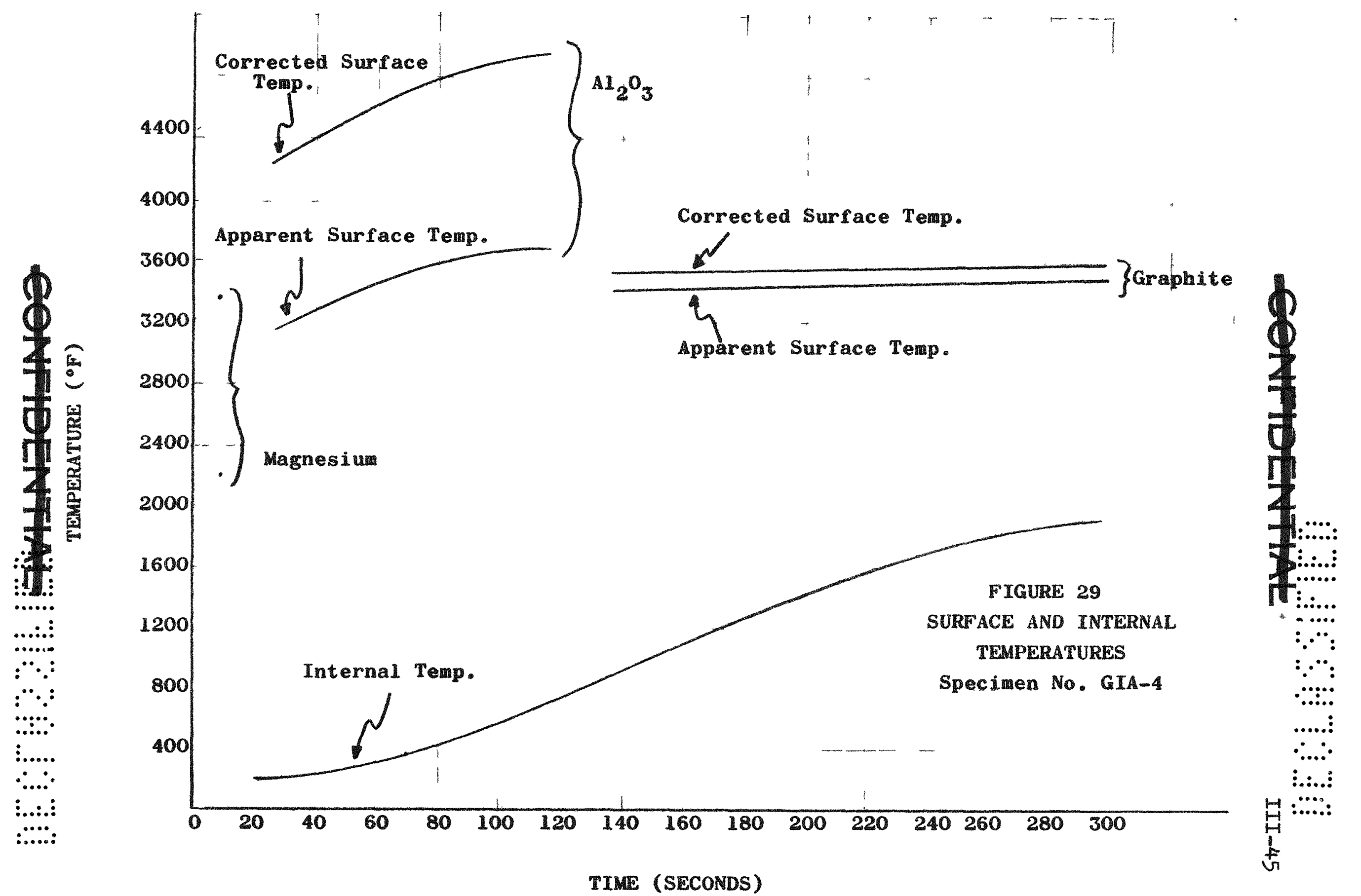




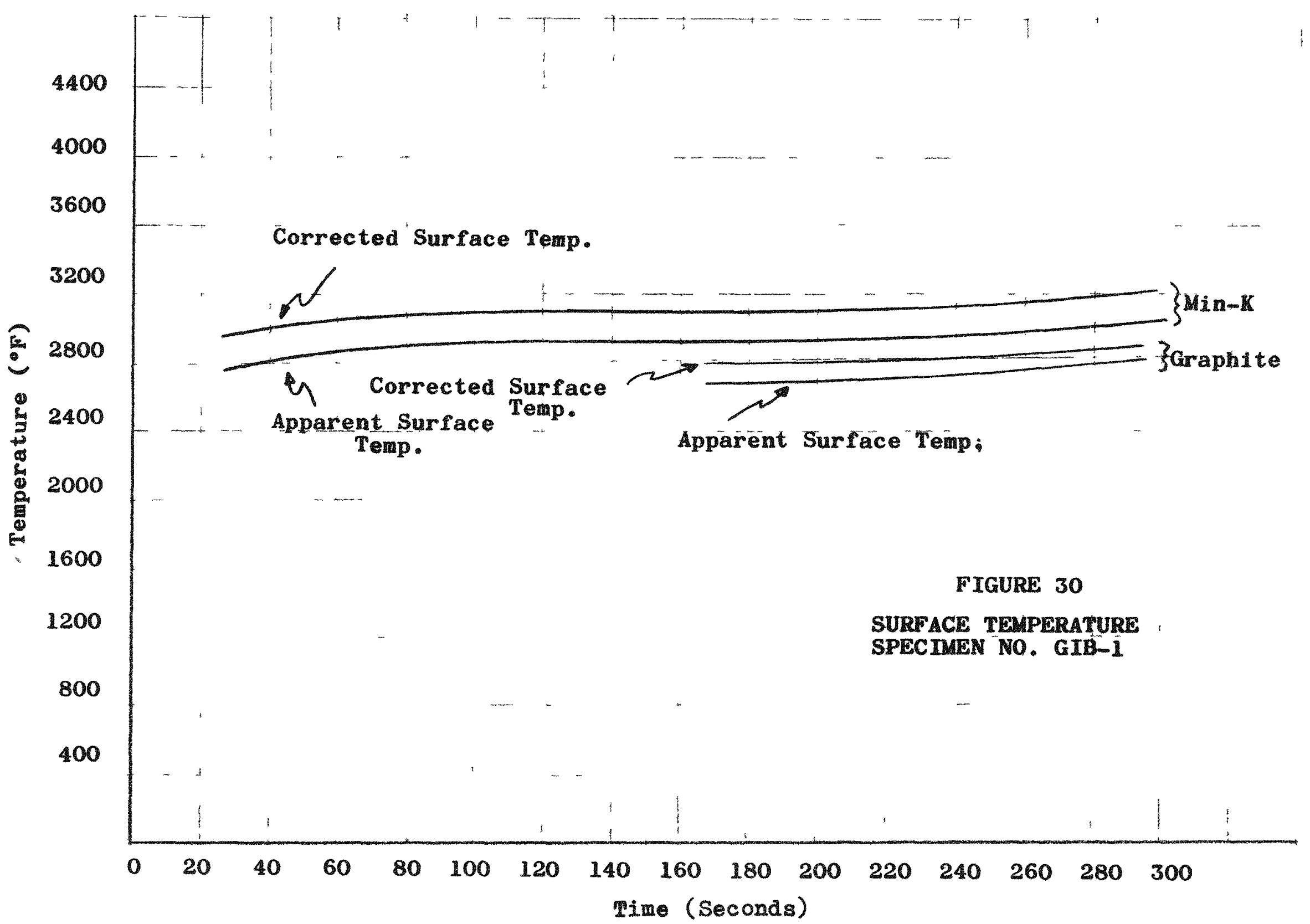



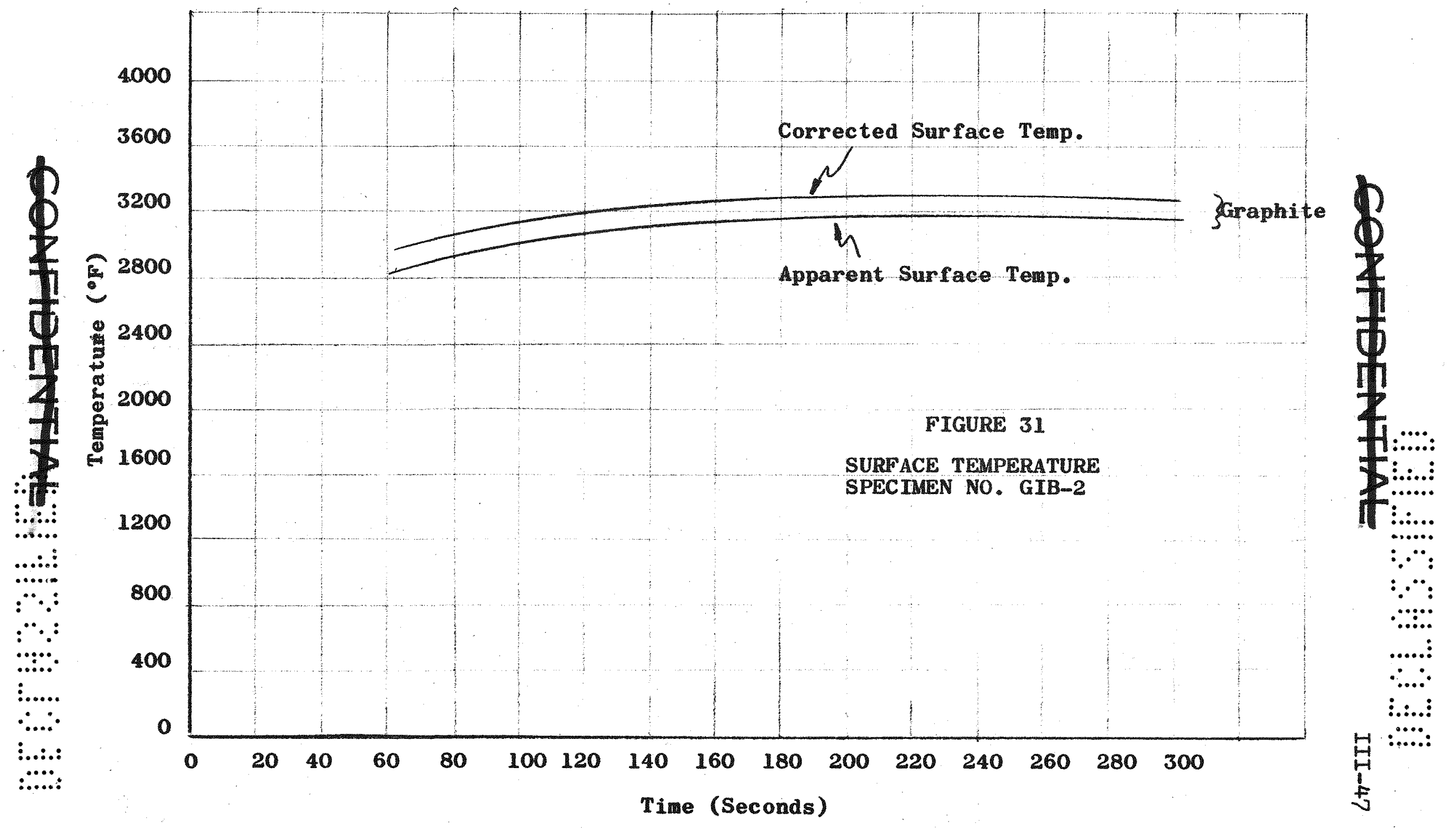

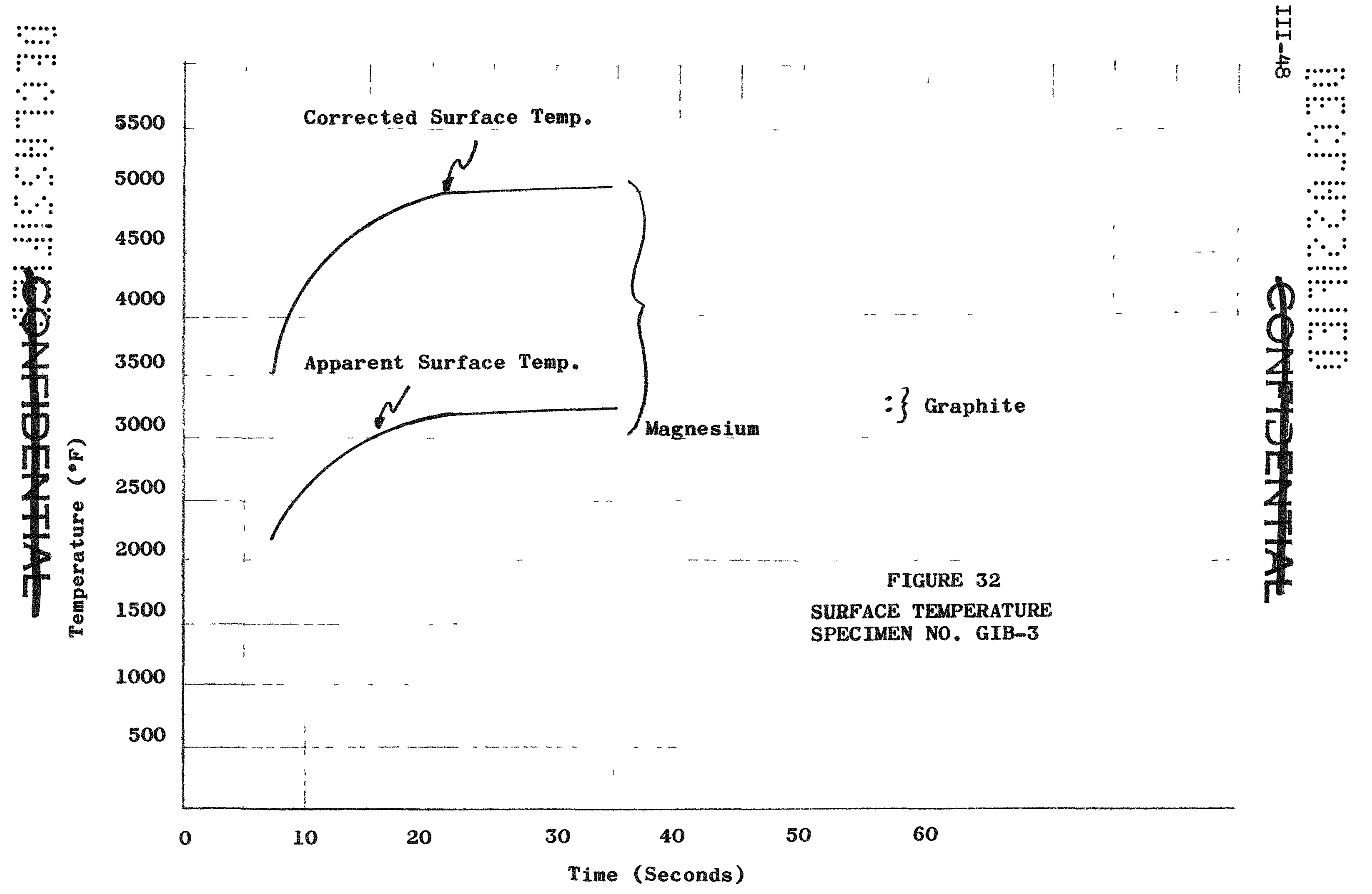


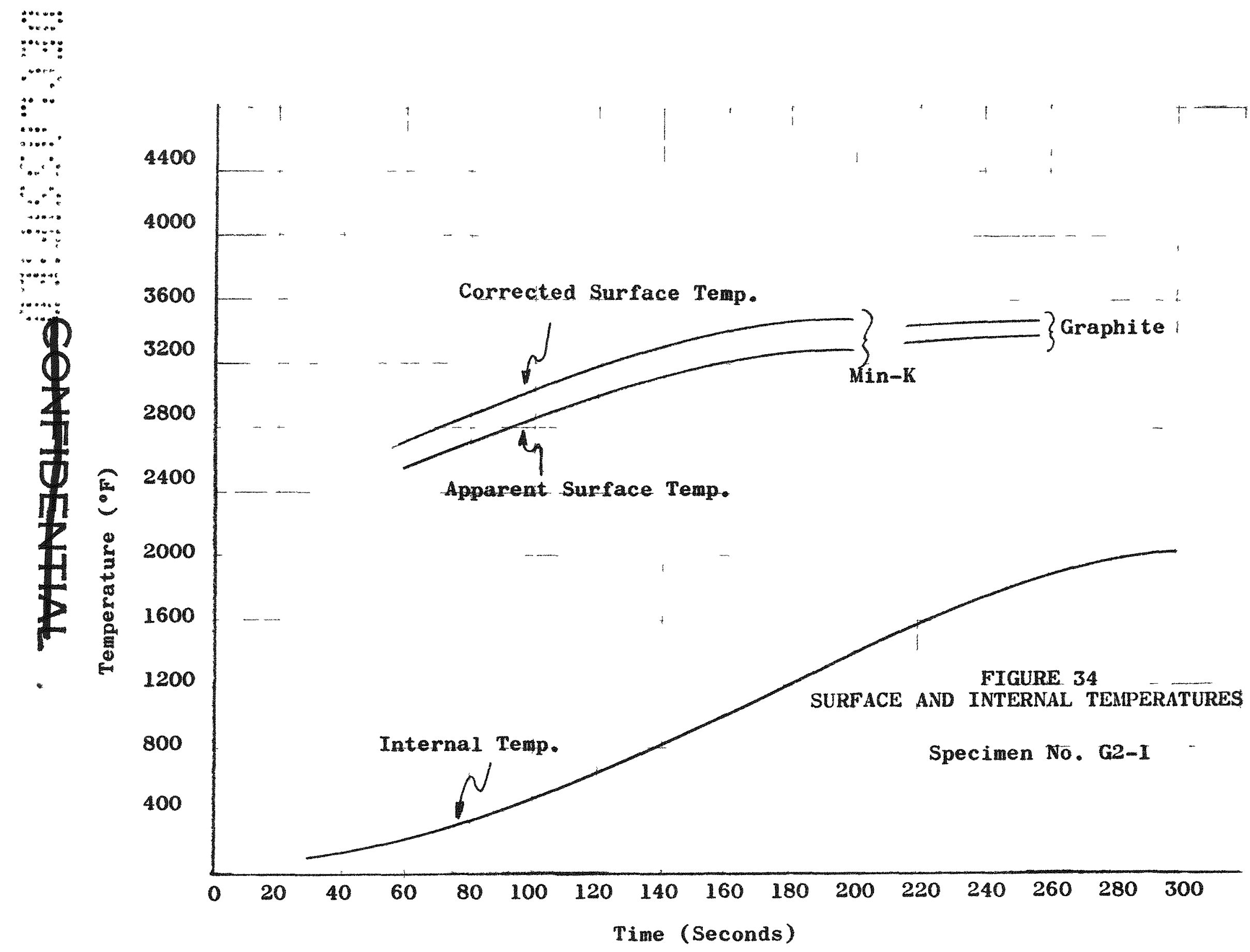



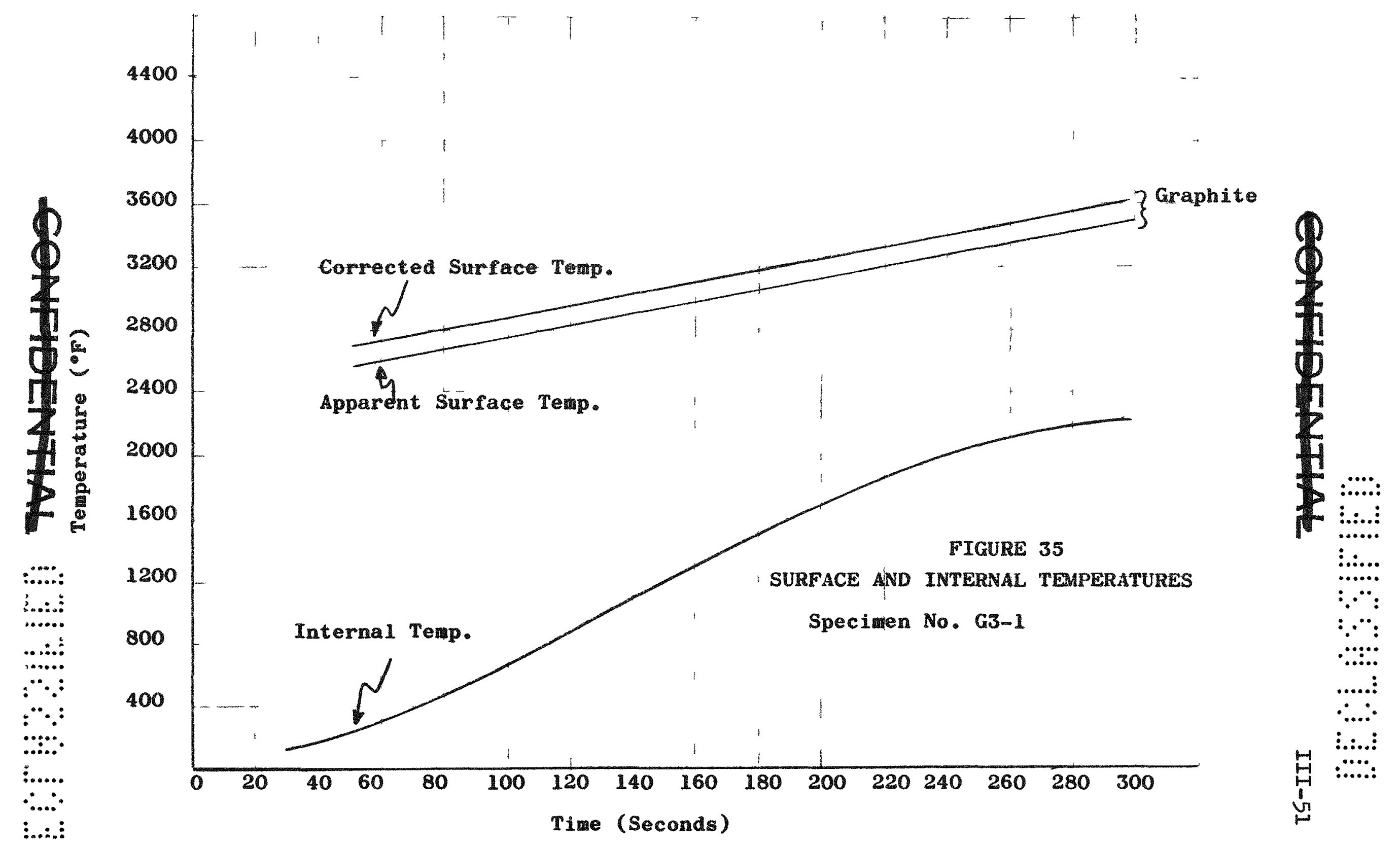


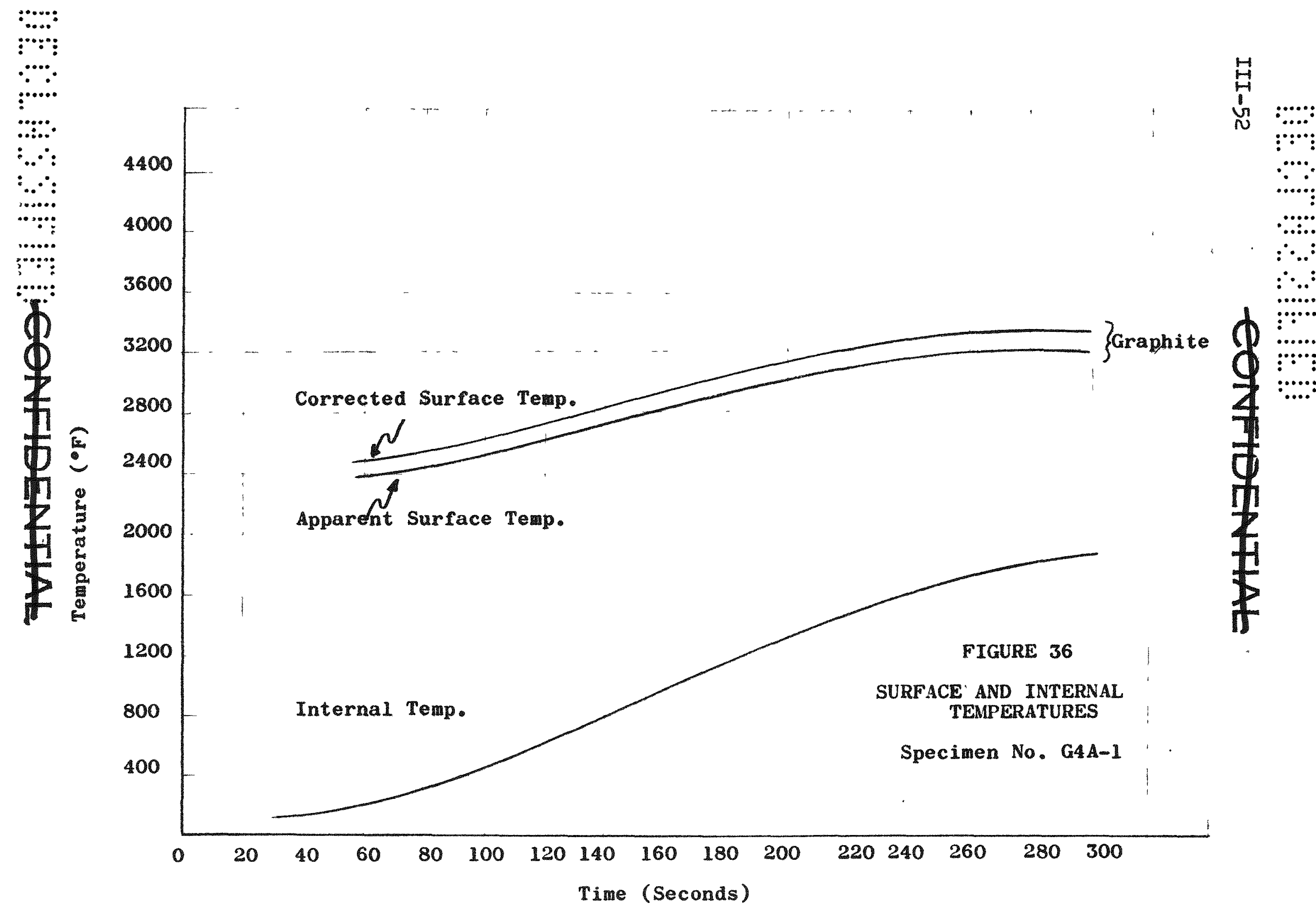




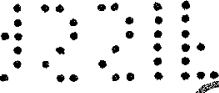

Specimen pre-test and post-mest data are presented in Table 5 .

Two motion picture cameras were employed to film the test, one with a filming rate of 16 frames per second and one with a filming rate of 0.7 frames per second. Since it was very difficult to obtain a reference to measure an ablation rate, the data is quite limited and the results of the two filmings are not very consistent. This can be attributed to many factors, of which the rollowing are representative:

1. The filu time rate accuracy is approximately t. $10 \%$.

2. There was difficulty in maintaining the specimens at a constant distance from the plasma flame as it ablated, since the distance had to be adjusted by a combination of visual and manual means.

3. The specimen outline on the films was not always precise. This condition might have been inproved by use of high speed photography.

The limitations above also affect the correlation between the simulated filght parameters and what intuitively would be expected of the ablation rates as the flight parameters are varied. Also, another contributing factor which adds to the above inconsistencies is that the repeatability of the parameters from one run to the next could not be accurately controlled. Moreover, the variation of the arc parameter values through a transverse section of the plasma flame is far from linear. For example, with a two inch diameter plasma are flame, 
TABLE 5

III -55

SUMMARY OF SPECIMEN PRETEST AND POST TEST DATA

\section{CONFHBENTIAL}

\begin{tabular}{|c|c|c|c|c|}
\hline $\begin{array}{c}\text { Specimen } \\
\text { Type }\end{array}$ & $\begin{array}{c}\text { Test } \\
\text { Orientation } \\
\end{array}$ & $\begin{array}{c}\text { Specimen } \\
\text { No. } \\
\end{array}$ & $\begin{array}{c}\text { Material } \\
\text { Mass } \\
\text { (grams) } \\
\end{array}$ & Description of Burnup \\
\hline 1 & 0 & $T-1$ & 147.3 & $\begin{array}{l}\text { Oxide layers immediately began form- } \\
\text { ing and attain equilibrium at } 120 \\
\text { seconds. Figure } 38 \text { shows a portion } \\
\text { of burnup, and Figure } 39 \text { shows model } \\
\text { after test with obvious oxide forma- } \\
\text { tions. Specimen remained in flame } \\
\text { for } 600 \text { seconds. }\end{array}$ \\
\hline
\end{tabular}

1

2
0

FHT -1

173.9

147.1

28.1

25.5

The specimen breached between 50 and 89 seconds where the failure occured in the closure weld. A portion of the specimen in the flame is show in Figure $4 \epsilon$ and Figure 47 shows specimen after test.

The outer Haynes-25 assembly ablated back exposing the inner tantalum lining at 40 seconds. The tantalu seconds. Fineached at approx. portions of specimen in flame and pigure 52 shows specimen after test. specimen was in flame for $140 \mathrm{sec}$
Material Ablation Rates
(in/sec) Act. Theor.

\section{$3.0 \times 10^{-4}$}

$3.38 \times 10^{-4} 1.22 \times 10^{-4}$

$\begin{array}{ll}\text { Haynes } & \text { Haynes } \\ 1.2 \times 10^{-2} & 1.06 \times 10^{-2}\end{array}$ Tantalum Tantalum
Results Chemical Analysis

High and low temperature phases of Tantelum oxides were readily identified with the high temperature forms, designated as $\alpha-\mathrm{A}_{2} \mathrm{O}_{3}$ alpha tantalu pentoxide), being well-ordered and phoses and or nitroce phastion on the side of the contained a metallic contaminant of molybdenum, approximately 1000 ppm. Figure 40 shows the oxide-tantalum interface on a portion of the capsule and Figure 41 shows a typical $x$-ray

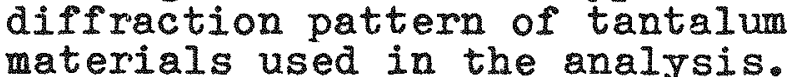

Homogenious phases of $a-\mathrm{TA}_{2} \mathrm{O}_{3}$ were detected along with low temperature phases. No nitrides and/or nitrogen

Exhibited same chemical properties as T-1. Figure 45 shows metallographic section through capsule.

Exhibited same chemical properties as T-1. Figures 48 and 49 show
oxide-tantalum interface bounderies.

Oxidation characteristics of tantalum were not effected by deposits of shows insursions of Haynes in Ium.

\section{COAFIOENTHAL}




\section{GOAFHOENTAL}

III-56

\begin{tabular}{|c|c|c|c|}
\hline $\begin{array}{c}\text { Specimen } \\
\text { Type } \\
\end{array}$ & $\begin{array}{c}\text { Test } \\
\text { Orientation } \\
\end{array}$ & $\begin{array}{c}\text { Specimen } \\
\text { No. } \\
\end{array}$ & $\begin{array}{l}\text { Material } \\
\text { Mass } \\
\text { (grams) } \\
\end{array}$ \\
\hline 4 & 0 & GGI-1 & 46.8 \\
\hline 5 & 0 & GBI-I & 48.1 \\
\hline 6 & 0 & T20-1a & 25.7 \\
\hline 6 & 0 & $\mathrm{~T} 2 \mathrm{O}-\mathrm{Ib}$ & 22.24 \\
\hline 6 & 0 & T20-2a & 25.7 \\
\hline 6 & 0 & T2O-2b & 21.23 \\
\hline 7 & 0 & $T G-1 a$ & 9.85 \\
\hline
\end{tabular}

औ

TABLE 5 (CONTINUED)

SUMMARY OF SPECIMEN PRETEST AND POST TEST DATA

Material Ablation (in/sec)

Description of Burnup

Magnesium front face ablated off in approx. 7 seconds exposing MinK to ablation for $130 \mathrm{sec}$, after which the carbon and Haynes were exposed to the plasma. Molten Haynes was observed spiling out of the gengenerator in the plasma. Fi 55 shows graphite plator after test. Specimen remained in plasma for 193 seconds.

Magnesium front face ablated off in approximately 20 seconds, exposing Min-K. Model separation occurred between 140-150 seconds. Renained in flame for 189 seconds. Figure 56 shows generator after test.

Pressure build-up inside capsule caused blow out at 228 seconds as indicated by Figure 60. Specimen

Capsule breached at 44 seconds. Oxide formation evident. Specimen remained in flame for 53 seconds. Figure 61 shows oxide formations and puncture on capsule after test.

Capsule breached at 7.63 seconds in flame. Test stopped after 8 seconds. Figure 62 shows specimen after test.

Capsule breached at approximately 3 seconds in flame and remained in

specimen after test.

Blow-out occurred at approximately 8 seconds in flame. Oxide for-

mations and puncture are visible

on Figure 64. Specimen remained in

flame for $18 \mathrm{sec}$. A sequence of

burnup is shown in Figures 65 and 66.
Results Act. Theor.

Magnes- Magnesium $1.64 \times 10^{-2}$ ium $2.27 \times 10^{-2}$

\section{Chemical Analysis}

Reaction of Haynes with carbon was

1. Bulk penetration of Haynes alloy

2. into graphite Figure 57.

Displacement of bar-like pieces of graphite into molten Haynes,

3. Iarge quantity of stable carbide in alloy bead, Figure 59.

Magnes- Magnes$\begin{array}{ll}\text { ium } \\ 5.5 \times 10^{-3} & \text { ium } \\ 2.4 \times 10^{-2}\end{array}$

Exhibited characteristics similar to Graphite Generator GGI-1.

$1.32 \times 10-4 \quad 1.28 \times 10^{-4}$

Exhibited same chemical properties as T-1.

$6.84 \times 10^{-4} 2.52 \times 10^{-4}$ $\operatorname{Txh}$

$3.75 \times 10^{-3} 3.53 \times 10^{-4}$

$1.0 \times 10^{-2} \quad 3.96 \times 10^{-4}$ Exhi

Exhibited same chemical properties as

$1.5 \times 10^{-3} \quad 1.2 \times 10^{-4}$ 


\begin{tabular}{|c|c|c|c|c|c|c|}
\hline $\begin{array}{l}\text { Specimen } \\
\text { Type } \\
\end{array}$ & $\begin{array}{l}\text { Test } \\
\text { Orientation } \\
\end{array}$ & $\begin{array}{c}\text { Specimen } \\
\text { No. } \\
\end{array}$ & $\begin{array}{l}\text { Material } \\
\text { Mass } \\
\text { (grams) } \\
\end{array}$ & Description of Burnup & $\begin{array}{l}\text { Material Ablation } \\
\text { Rates } \\
\text { (in/sec) } \\
\text { Act. Theor. }\end{array}$ & $\begin{array}{l}\text { Results } \\
\text { Chemical Analysis } \\
\end{array}$ \\
\hline 7 & 0 & $T 6-1 b$ & 9.62 & $\begin{array}{l}\text { Burn-through at } 10 \text { seconds. Some } \\
\text { oxides observed, as seen in Fig- } \\
\text { ure } 67 \text {. }\end{array}$ & $1.2 \times 10^{-3} 2.5 \times 10^{-4}$ & $\begin{array}{l}\text { Exhibited same chemical properties } \\
\text { as T-1. }\end{array}$ \\
\hline 7 & 0 & $T 6-2 a$ & 9.83 & $\begin{array}{l}\text { Burn-through at } 3 \text { seconds. No } \\
\text { oxides observed after test as } \\
\text { shown in Figure } 68 \text {. Specimen re- } \\
\text { mained in flame for } 4.37 \text { seconds. }\end{array}$ & $4 \times 10^{-3} \quad 3.88 \times 10^{-4}$ & $\begin{array}{l}\text { Exhibited same chemical properties } \\
\text { as T-1. }\end{array}$ \\
\hline \multirow[t]{2}{*}{8} & \multirow[t]{2}{*}{0} & \multirow[t]{2}{*}{$\mathrm{HT}-1$} & $\begin{array}{l}\text { Tante- } \\
\text { Ium } 8.0 \\
\text { Haynes } \\
54.89\end{array}$ & \multirow{2}{*}{$\begin{array}{l}\text { Haynes began melting at } 16 \text { sec- } \\
\text { onds, burm through at approxi- } \\
\text { mateig } 45 \text { seconds. Specimen re- } \\
\text { mained in flame for } 56 \text { seconds. } \\
\text { Figure } 69 \text { shows specimen after } \\
\text { test. }\end{array}$} & \multirow[t]{2}{*}{$\begin{array}{c}\text { Haynes } \\
1.07 \times 10^{-2} \\
1.12 \times 10^{-2}\end{array}$} & \multirow[t]{2}{*}{$\begin{array}{l}\text { Exhibited same chemical properties } \\
\text { as FHT-1. }\end{array}$} \\
\hline & & & $\begin{array}{l}\text { Total } \\
62.89\end{array}$ & & & \\
\hline \multirow[t]{2}{*}{8} & \multirow[t]{2}{*}{0} & \multirow[t]{2}{*}{$\mathrm{HT}-2$} & $\begin{array}{l}\text { Tanta- } \\
\text { lum } \\
8.0269 \\
\text { Haynes } \\
56.65\end{array}$ & \multirow{2}{*}{$\begin{array}{l}\text { Haynes began melting at } 5 \text { sec- } \\
\text { onds burn through at approxi- } \\
\text { mately } 15 \text { seconds. Specimen } \\
\text { remained in flame for } 29 \text { seconds. } \\
\text { Figures } 70 \text { and } 71 \text { show portion of } \\
\text { specimen burnup in flame. Fig- } \\
\text { ure } 72 \text { shows specimen after test. }\end{array}$} & \multirow[t]{2}{*}{$\begin{array}{l}\text { Haynes } \\
3.13 \times 10^{-2} \\
1.58 \times 10^{-2}\end{array}$} & \multirow[t]{2}{*}{$\begin{array}{l}\text { Exhibited same chemical properties } \\
\text { as FHT-1. }\end{array}$} \\
\hline & & & $\begin{array}{l}\text { Total } \\
64.6769\end{array}$ & & & \\
\hline \multirow[t]{2}{*}{9} & \multirow[t]{2}{*}{90} & \multirow[t]{2}{*}{$\mathrm{HT}-3$} & $\begin{array}{l}\text { Tanta- } \\
\text { lum } \\
8.52 \\
\text { Haynes } \\
55.0\end{array}$ & $\begin{array}{l}\text { Burn through occurred at approxi- } \\
\text { mately } 8.7 \text { seconds. Remained in } \\
\text { flame for } 9 \text { seconds. Figure } 73 \\
\text { shows specimen after test. }\end{array}$ & \multirow[t]{2}{*}{$\begin{array}{rl}\text { Hagne } & \text { Haynes } \\
\sim 1.0 \times 10^{-2} & 7.21 \times 10^{-3}\end{array}$} & \multirow[t]{2}{*}{$\begin{array}{l}\text { Exhibited same chemical properties } \\
\text { as FHT-1. Figure } 74 \mathrm{~A} \text { shows the } \\
\text { reaction area of Haynes alloy with } \\
\text { the environment. Figure } 74 \mathrm{~B} \text { shows } \\
\text { penetration of molten tantalum into } \\
\text { Haynes alloy. }\end{array}$} \\
\hline & & & $\begin{array}{l}\text { Total } \\
63.52\end{array}$ & & & \\
\hline 8 & 90 & HT -4 & $\begin{array}{l}\text { Tanta- } \\
\text { Ium } \\
7.641 \\
\text { Haynes } \\
54.85\end{array}$ & $\begin{array}{l}\text { Burn through occurred at } 8 \text { sec- } \\
\text { onds, shearing occurred at } 25 \text { sec- } \\
\text { onds. Figure } 75 \text { shows specimen } \\
\text { after test. }\end{array}$ & $\begin{array}{cl}\text { Haynes } & \text { Haynes } \\
\sim 1.0 \times 10^{-2} & 1.45 \times 10^{-2}\end{array}$ & $\begin{array}{l}\text { Exhibited same chemical properties as } \\
\text { FHT-1. }\end{array}$ \\
\hline
\end{tabular}


草:

TABLE 5 (CONTINUED)

SUMMARY OF SPECIMEN PRETEST AND POST TEST DATA

\begin{tabular}{|c|c|c|c|}
\hline $\begin{array}{c}\text { Specimen } \\
\text { Type } \\
\end{array}$ & $\begin{array}{c}\text { Test } \\
\text { Orientation }\end{array}$ & $\begin{array}{c}\text { Specimen } \\
\text { No. } \\
\end{array}$ & $\begin{array}{c}\text { Material } \\
\text { Mass } \\
\text { - (Erams) } \\
\end{array}$ \\
\hline 9 & 0 & AHT-1 & $\begin{array}{l}\text { Tanta- } \\
\text { lum } \\
6.6614 \\
\text { Haynes } \\
55.817\end{array}$ \\
\hline 9 & 0 & AHT-2 & $\begin{array}{l}\text { Tanta- } \\
\text { Ium } \\
7.3562 \\
\text { Haynes } \\
56.1308\end{array}$ \\
\hline 9 & 90 & AHT -3 & $\begin{array}{l}\text { Tanta- } \\
\text { lum } \\
7.7783 \\
\text { Haynes } \\
56.321\end{array}$ \\
\hline 9 & 90 & AHT -4 & $\begin{array}{l}\text { Tanta- } \\
\text { lum } \\
7.5261 \\
\text { Haynes } \\
56.6397\end{array}$ \\
\hline \multirow[t]{2}{*}{10} & 0 & GIA-1 & $\begin{array}{l}\text { Haynes \& } \\
\mathrm{Al}_{2} \mathrm{O}_{3} \\
68.7 \\
\text { Graphite } \\
138.391 \\
\text { Magnes- } \\
\text { ium } \\
95.165\end{array}$ \\
\hline & & & $\begin{array}{l}\text { Total } \\
302.256\end{array}$ \\
\hline 10 & 0 & $4=1$ & $\begin{array}{l}\text { Haynes \& } \\
\mathrm{Al}_{2} \mathrm{O}_{3} \\
69.0 \\
\text { Graphite } \\
138.133 \\
\text { Magnes- } \\
\text { ium } \\
98.7585 \\
\text { Total }\end{array}$ \\
\hline
\end{tabular}

GONFIOENTHAL 305.8915

\section{Description of Burnup}

No burn through occurred, however, aluminum oxide partially ablated and body of specimen became red
hot. Figure 76 shows specimen after test. Test ran for 277 seconds.

Description same as AHT-1. Figures 78 and 79 show a portion of burnup. Figure 80 shows specimen after test. Test ran for 277 seconds.

Burn through occurred at 10 seconds. Specimen sheared at 33 seconds. FigSpecimen in flame for 39.5 seconds.

Burn through occurred at 15 seconds. Specimen sheared at 130 170 seconds. Figure 82 shows specimen after test.

Cap was ablated off at approx. 45 94 seconds, capsule intact, but ure 83. Figure $84 \AA$ shows capsule removed from generator after test. Specimen was in flame for $300 \mathrm{sec}-$ onds. onds. Shell break-up occurred at 220 seconds, segmented blocks drop away at 250 seconds. Specimen pigure 84B shows capsule after test. sec. Shell break-up occurred at coating as can be

\section{Cap was removed at approx. $45 \mathrm{sec}-$}

Material Ablation (in/sec)

Act. Theor.

Haynes
$\sim 1.0 \times 10^{-2}$

Haynes
$\sim 1.0 \times 10^{-2}$
$1.49 \times 10^{-2}$

Magnes- Magnesium $2.70 \times 10^{-3}$ ium $1.1 \times 10^{-2}$

Magnes- Magnesium $2.7 \times 10^{-3} \stackrel{\text { ium }}{1.4 \times 10^{-2}}$
Results

\section{Chemical Analysis}

Figure 77A shows relatively large vold areas in Haynes alloy dirFigure $77 \mathrm{~B}$ shows the ${ }^{2}$ itterface of reaction between the Tantalum inner capsule and Haynes housing.

Exhibited same chemical properties as AHT-1.

Exhibited same chemical properties as $\mathrm{FHT}-1$.

Exhibited same chemical properties as FHT-1.

Magnesium oxide deposit on outer shell, no eviance of reaction of haynes with molten area-solid area interface of

Magnesium oxide deposit on shell. No evidence of Haynes reacting with carbon, no nitrites or carbides formed. Figures $87 \mathrm{~A}$ and $87 \mathrm{~B}$ show the molten area-solid area interface of haynes pattern is obvious. 
SUMMARY OF SPECIMEN PRETEST AND POST TEST DATA

\section{COAFTDENTHAL}$$
\text { III }-59
$$

\begin{tabular}{|c|c|c|c|c|c|c|}
\hline \multirow{2}{*}{$\begin{array}{c}\text { Specimen } \\
\text { Type } \\
\end{array}$} & \multirow{2}{*}{$\begin{array}{c}\text { Test } \\
\text { Orientation }\end{array}$} & \multirow{2}{*}{$\begin{array}{c}\text { Specimen } \\
\text { No. } \\
\end{array}$} & \multirow{2}{*}{$\begin{array}{c}\text { Material } \\
\text { Mass } \\
\text { (grams) } \\
\end{array}$} & \multirow[b]{2}{*}{ Description of Burnup } & \multicolumn{2}{|c|}{$\begin{array}{c}\text { Material Ablation } \\
\text { Rates } \\
\text { (in/sec) }\end{array}$} \\
\hline & & & & & Act. & Theor. \\
\hline \multirow[t]{2}{*}{10} & \multirow[t]{2}{*}{0} & \multirow[t]{2}{*}{ GIA-3 } & $\begin{array}{l}\text { Haynes \& } \\
\mathrm{Al} 2 \mathrm{O}_{3} \\
68.3 \\
\text { Graphite } \\
137.912 \\
\text { Magnes- } \\
\text { ium } \\
97.7824\end{array}$ & \multirow[t]{2}{*}{$\begin{array}{l}\text { Front face of shell removed at } 20 \\
\text { seconds, half of outer housing } \\
\text { ablated, but still intact as seen } \\
\text { in Figure } 88 \text {. Figure } 84 \mathrm{D} \text { shows } \\
\text { capsule after test. Specimen in } \\
\text { flame for } 206 \text { sec. }\end{array}$} & \multirow[t]{2}{*}{$\begin{array}{l}\text { Magnes- } \\
\text { ium } \\
6.25 \times 10^{-3}\end{array}$} & \multirow[t]{2}{*}{$\begin{array}{l}\text { Magnes- } \\
\text { ium } \\
2.0 \times 10^{-3}\end{array}$} \\
\hline & & & $\begin{array}{l}\text { Total } \\
303.9944\end{array}$ & & & \\
\hline \multirow[t]{2}{*}{10} & \multirow[t]{2}{*}{0} & \multirow[t]{2}{*}{ GIA -4} & $\begin{array}{l}\text { Haynes \& } \\
\text { Al20 } \\
69.05 \\
\text { Graphite } \\
\text { 137.446 } \\
\text { Magnes- } \\
\text { ium } \\
98.827\end{array}$ & \multirow[t]{2}{*}{$\begin{array}{l}\text { Cap was removed after } 30 \text { seconds. } \\
\text { Shell break-up occurred at approx. } \\
100 \text { seconds, half of capsule } \\
\text { ablated as can be seen in Figure } \\
90 \text {. Figure } 84 \mathrm{C} \text { shows capsule } \\
\text { after test. Figures } 91,92 \text {, and } \\
93 \text { show sequence of specimen } \\
\text { burnup. Specimen in flame for } \\
300 \text { sec. }\end{array}$} & \multirow[t]{2}{*}{$\begin{array}{l}\text { Magnes- } \\
\text { 1um } \\
3.5 \times 10^{-3}\end{array}$} & \multirow[t]{2}{*}{$\begin{array}{l}\text { Magnes- } \\
\text { ium } \\
1.5 \times 10^{-2}\end{array}$} \\
\hline & & & $\begin{array}{l}\text { Total } \\
305.323\end{array}$ & & & \\
\hline \multirow[t]{2}{*}{11} & \multirow[t]{2}{*}{90} & \multirow[t]{2}{*}{ GIB-I } & $\begin{array}{l}\text { Haynes \& } \\
\text { A1203 } \\
69.13 \\
\text { Graphite } \\
138.994 \\
\text { Magnes- } \\
\text { ium } \\
99.129\end{array}$ & \multirow[t]{2}{*}{$\begin{array}{l}\text { Surface of shell burned through at } \\
\text { approximately } 45 \text { seconds, no break- } \\
\text { up as can be seen in Figure } 95 \text {. } \\
\text { Specimen in flame for } 283 \text { seconds. }\end{array}$} & \multirow[t]{2}{*}{$\begin{array}{l}\text { Magnes- } \\
\text { ium } \\
2.7 \times 10^{-3}\end{array}$} & \multirow[t]{2}{*}{$\begin{array}{l}\text { Magnes- } \\
\text { ium } \\
1.8 \times 10^{-2}\end{array}$} \\
\hline & & & $\begin{array}{l}\text { Total } \\
307.253\end{array}$ & & & \\
\hline \multirow[t]{2}{*}{11} & \multirow[t]{2}{*}{90} & \multirow[t]{2}{*}{ GIB -2} & $\begin{array}{l}\text { Haynes \& } \\
\text { A1503 } \\
67.7 \\
\text { Graphite } \\
138.969 \\
\text { Magnes- } \\
\text { ium } \\
100.492\end{array}$ & \multirow[t]{2}{*}{$\begin{array}{l}\text { Surface of shell burned through at } \\
9 \text { seconds, breakup occurred at } \\
\text { approx. } 250 \text { seconds. Figure } 96 \\
\text { shows specimen after test. }\end{array}$} & \multirow[t]{2}{*}{$\begin{array}{l}\text { Magnes- } \\
\text { ium } \\
1.5 \times 10^{-2}\end{array}$} & \multirow[t]{2}{*}{$\begin{array}{l}\text { Magnes- } \\
\text { ium } \\
2.2 \times 10^{-3}\end{array}$} \\
\hline & & & $\begin{array}{l}\text { Total } \\
307.161\end{array}$ & & & \\
\hline
\end{tabular}

GOWFETAE

\section{Results
Chemical Analysis}

Magnesium oxide deposits on shell. Change in chemical composition of little reaction with carbon was vident. No nitrides formed. 89B show molten area-solid area interface of Haynes. insulation.

Magnesium oxide deposits on shell. little reaction of carbon, no nitrides formed. Figures area interface of Haynes and oxides present on outer surface.

Magnesium oxide deposits on shell. No reaction of carbon with Haynes, no nitrides.

Magnesium oxide deposits on shell minor phase of magnesium carbide $\mathrm{Mg}_{2} \mathrm{C}_{3}$ was formed with the Megnesoxide, no reaction of Haynes with carbon, no nitride formation. 


\section{(

III-60

CONFIOENTFHE

\begin{tabular}{|c|c|c|c|c|}
\hline $\begin{array}{c}\text { Specimen } \\
\text { Type } \\
\end{array}$ & $\begin{array}{c}\text { Test } \\
\text { Orientation }\end{array}$ & $\begin{array}{c}\text { Specimen } \\
\text { No. }\end{array}$ & $\begin{array}{l}\text { Material } \\
\text { Mass } \\
\text { (grams) } \\
\end{array}$ & Description of Burnup \\
\hline \multirow[t]{2}{*}{11} & \multirow[t]{2}{*}{90} & \multirow[t]{2}{*}{$G I B-3$} & $\begin{array}{l}\text { Haynes \& } \\
\text { Al1203 } \\
69.1 \\
\text { Graphite } \\
138.971 \\
\text { Magnes- } \\
\text { ium } \\
100.354\end{array}$ & \multirow[t]{2}{*}{$\begin{array}{l}\text { Burn through of shell occurred at } \\
\text { approx. } 20 \text { sec. Shell break- } \\
\text { occurred at } 53.4 \text { seconds, capsule } \\
\text { remained intact. Figure } 97 \text { and } \\
98 \text { show a sequence of specimen } \\
\text { burnup. Figure } 99 \text { shows specimen } \\
\text { after test. }\end{array}$} \\
\hline & & & $\begin{array}{l}\text { Total } \\
308.425\end{array}$ & \\
\hline \multirow[t]{2}{*}{11} & \multirow[t]{2}{*}{90} & \multirow[t]{2}{*}{ GIB -4} & $\begin{array}{l}\text { Mag. \& } \\
\text { Al203 } \\
68.99 \\
\text { Graphite } \\
138.595 \\
\text { Magnes- } \\
\text { ium } \\
99.452\end{array}$ & \multirow[t]{2}{*}{$\begin{array}{l}\text { Shell burn through at } 45.3 \mathrm{sec}- \\
\text { onds, shell breakup at } 53.4 \mathrm{sec}- \\
\text { onds, capsule remained intact. } \\
\text { Figure } 100 \text { shows specimen after } \\
\text { test. }\end{array}$} \\
\hline & & & $\begin{array}{l}\text { Total } \\
307.017\end{array}$ & \\
\hline \multirow[t]{2}{*}{12} & \multirow[t]{2}{*}{0} & \multirow[t]{2}{*}{ G2-1 } & $\begin{array}{l}\text { Haynes \& } \\
\text { Al } 2 \text { Oz } \\
69.09 \\
\text { Graphite } \\
137.514 \\
\text { Magnes- } \\
\text { ium } \\
96.515\end{array}$ & \multirow[t]{2}{*}{$\begin{array}{l}\text { Cap removed at } 18.5 \mathrm{sec} \text {, gen- } \\
\text { erator remained intact as can be } \\
\text { seen in Figure } 101 .\end{array}$} \\
\hline & & & $\begin{array}{l}\text { Total } \\
303.119\end{array}$ & \\
\hline \multirow[t]{2}{*}{13} & \multirow[t]{2}{*}{0} & \multirow[t]{2}{*}{ G3-1 } & $\begin{array}{l}\text { Haynes } \\
76.79 \\
\text { Graphite } \\
137.671 \\
\text { Magnes- } \\
\text { ium } \\
99.989\end{array}$ & \multirow[t]{2}{*}{$\begin{array}{l}\text { Cap removed at } 18.5 \text { sec., break- } \\
\text { up at } 268 \text { seconds. One quarter } \\
\text { of capsule remained imbeded in } \\
\text { carbon as shown in Figure } 104 .\end{array}$} \\
\hline & & & $\begin{array}{l}\text { Total } \\
3.4 .45\end{array}$ & \\
\hline
\end{tabular}

TABLE 5 (CONTINUED)

SUMMARY OF SPECIMENT PRETEST AND POST TEST DATA

$\begin{aligned} & \text { Material Ablation } \\ & \text { Rates } \\ & \text { (in/sec) }\end{aligned}$
Act. Theor. Results

Magnes- Magnes-

$\begin{array}{ll}\text { ium } \\ 6.3 \times 10^{-3} & \text { ium } \\ 2.6 \times 10^{-2}\end{array}$

Magnesium oxide deposits on shell, no reaction of Haynes with carbon, no nitrides, no carbides.

Magnes- Magnes$\frac{\text { ium }}{2.6 \times 10^{-3}} \stackrel{\text { ium }}{2.7 \times 10^{-2}}$

Same chemical properties as GIB-3.

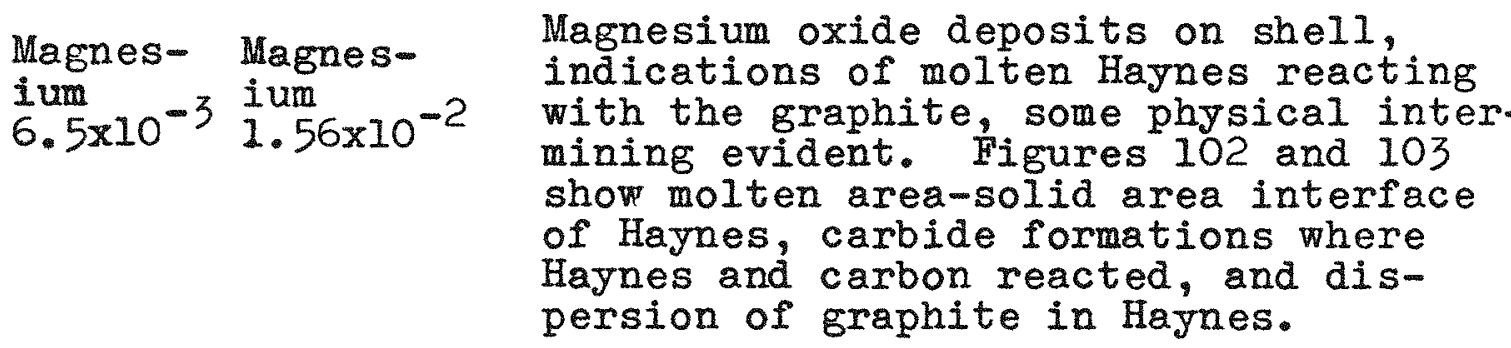
with the graphite, some physical inter mining evident. Figures 102 and 103 show molten area-solid area interface Haynes and carbon reacted, and dis persion of graphite in Haynes.

Magnes- Magnes$\frac{\text { ium }}{6.5 \times 10^{-3}} \stackrel{\text { ium }}{1.5 \times 10^{-2}}$

Magnesium oxide deposits on shell indications of molten Haynes "wetting" the graphite with physical intermixing, Figures 105 and 106 show haynes carbon interface, carbide formations at and near the interface, and dispersion of arite in Haynes. 


\section{COAHFAEATHA}

TABLE 5 (CONTINUED)

III-6I SUMMARY OF SPECIMEN PRETEST AND POST TEST DATA

\begin{tabular}{|c|c|c|c|c|}
\hline $\begin{array}{c}\text { Specimen } \\
\text { Type } \\
\end{array}$ & $\begin{array}{c}\text { Test } \\
\text { Crientation } \\
\end{array}$ & $\begin{array}{c}\text { Specimen } \\
\text { No. }\end{array}$ & $\begin{array}{c}\text { Material } \\
\text { Mass } \\
\text { (grams) } \\
\end{array}$ & Description of Burnup \\
\hline \multirow[t]{2}{*}{14} & \multirow[t]{2}{*}{0} & \multirow[t]{2}{*}{$G 4 A-1$} & $\begin{array}{l}\text { Haynes \& } \\
\text { Al } 2^{\mathrm{O}} 3 \\
67.7 \\
\text { Graphite } \\
138.647 \\
\text { Magnes- } \\
\text { ium } \\
99.758\end{array}$ & \multirow[t]{2}{*}{$\begin{array}{l}\text { Cap removed at } 15 \text { seconds, shell } \\
\text { brokeup at } 216 \text { seconds, Ai, }{ }^{03} \\
\text { tip of capsule blew out at approx. } \\
225 \text { seconds. Figure } 107 \text { shows } \\
\text { portion of Specimen burnup. Fig- } \\
\text { ure } 108 \text { shows specimen after test. }\end{array}$} \\
\hline & & & $\begin{array}{l}\text { Total } \\
306.102\end{array}$ & \\
\hline \multirow[t]{2}{*}{15} & \multirow[t]{2}{*}{90} & \multirow[t]{2}{*}{ G4B-1 } & $\begin{array}{l}\text { Haynes \& } \\
\mathrm{Al}_{2} \mathrm{O}_{3}\end{array}$ & \multirow{2}{*}{$\begin{array}{l}\text { Burn through occurred at approx. } \\
20 \text { seconds. Shell breakup began } \\
\text { at } 135 \text { seconds, fuel block and } \\
\text { capsule remain intact, as seen in } \\
\text { Figure } 110 \text {. Specimen remained in } \\
\text { flame for } 370 \text { seconds. }\end{array}$} \\
\hline & & & $\begin{array}{l}68.2 \\
\text { Graphite } \\
141.345 \\
\text { Magnes- } \\
\text { ium } \\
97.607\end{array}$ & \\
\hline
\end{tabular}

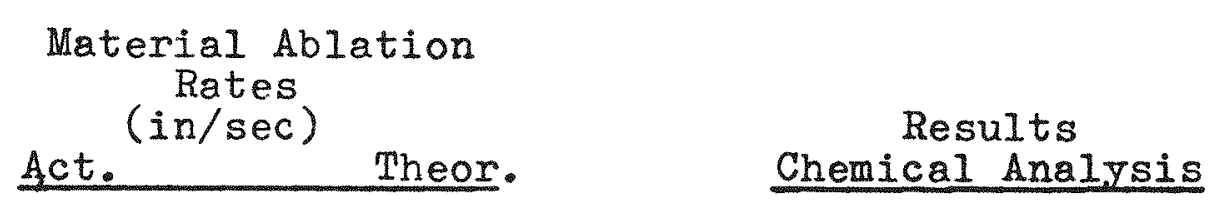

Magnes- Magnes-

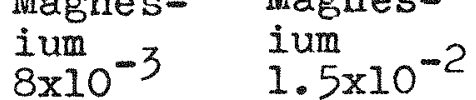

Magnesium oxide deposits on shell, reaction product on surface. Figpattern, and an unusual crak due

to thermal shocking.

\section{Magnes- Magnes-}

ium
$6.25 \times 10^{-3}$
$2.5 \times 10^{-2}$
Magnesium oxide deposits on shell no nitrides or carbides formed. 


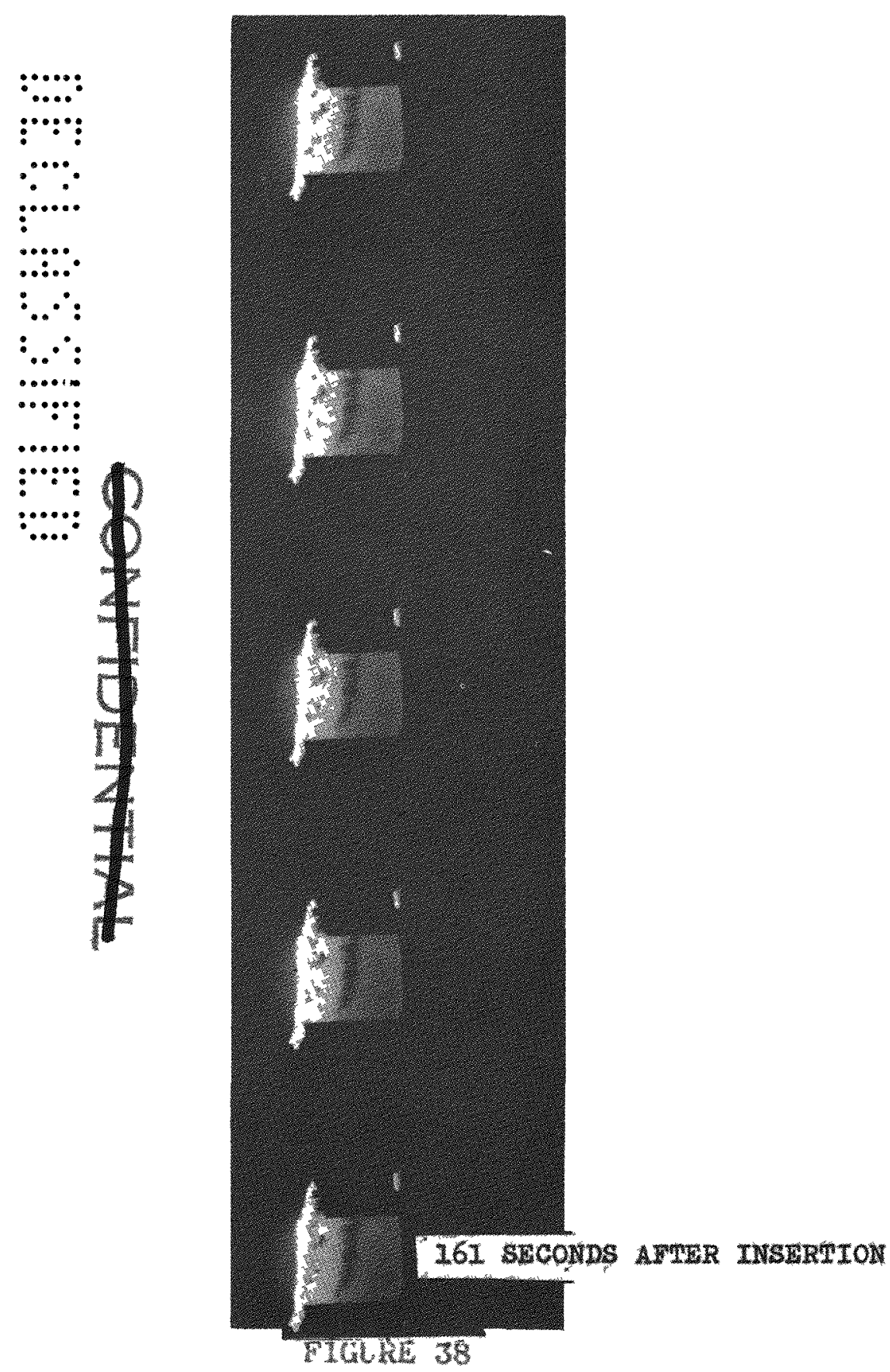

MLASMA TEST SPECIMEN T-1 IN PLASMA

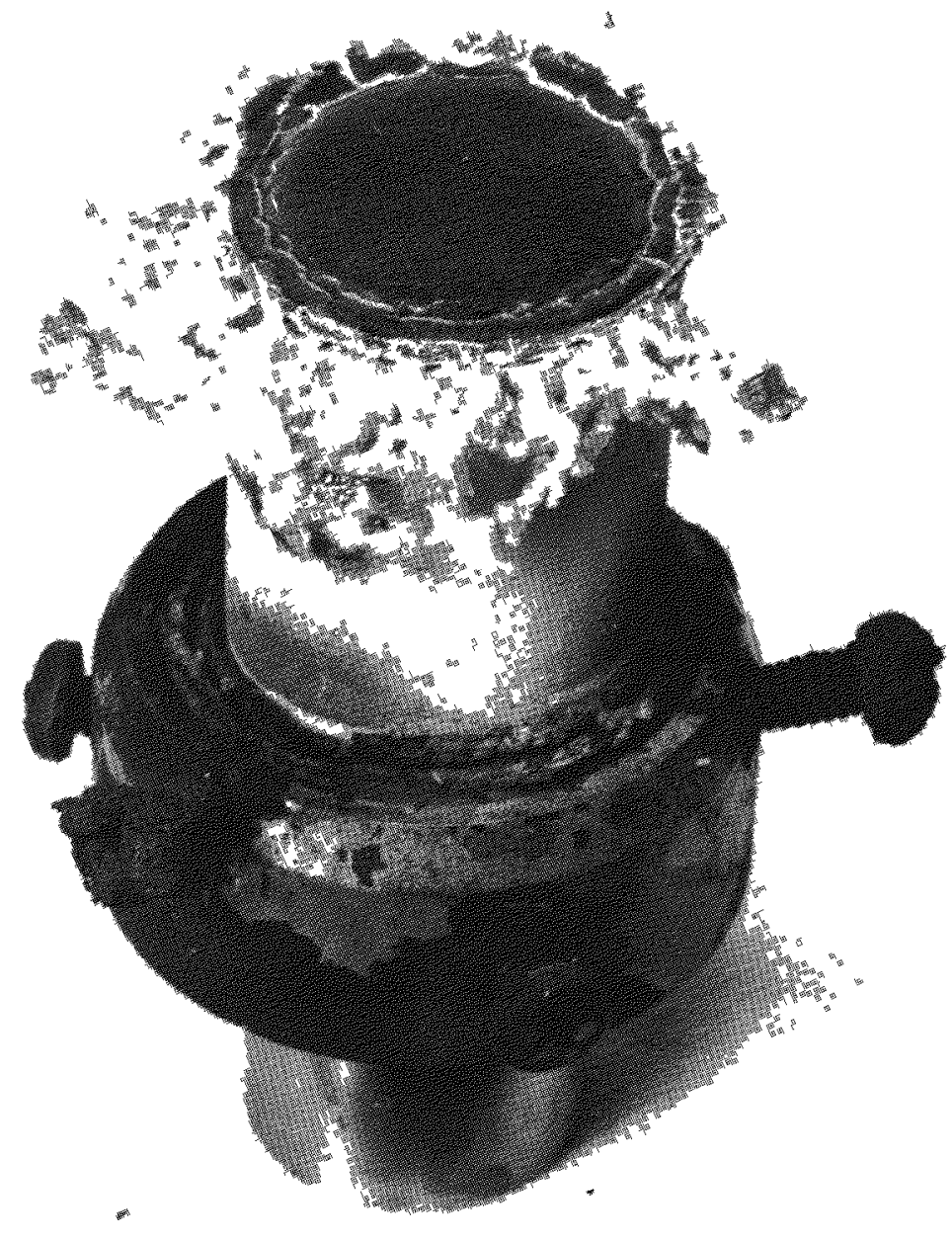

8

:....: $\because \because \because$

$\cdots$.

$\cdots \cdot$

$\because$

$\therefore . .$.

$\therefore$

D):

Q $: \cdots: \cdot:$

$4: . . .$.

7

$\frac{1}{7}$

FrGURE 39

PLASMA TEST SITECIMEN TM-1 POST TEST CONDITION 


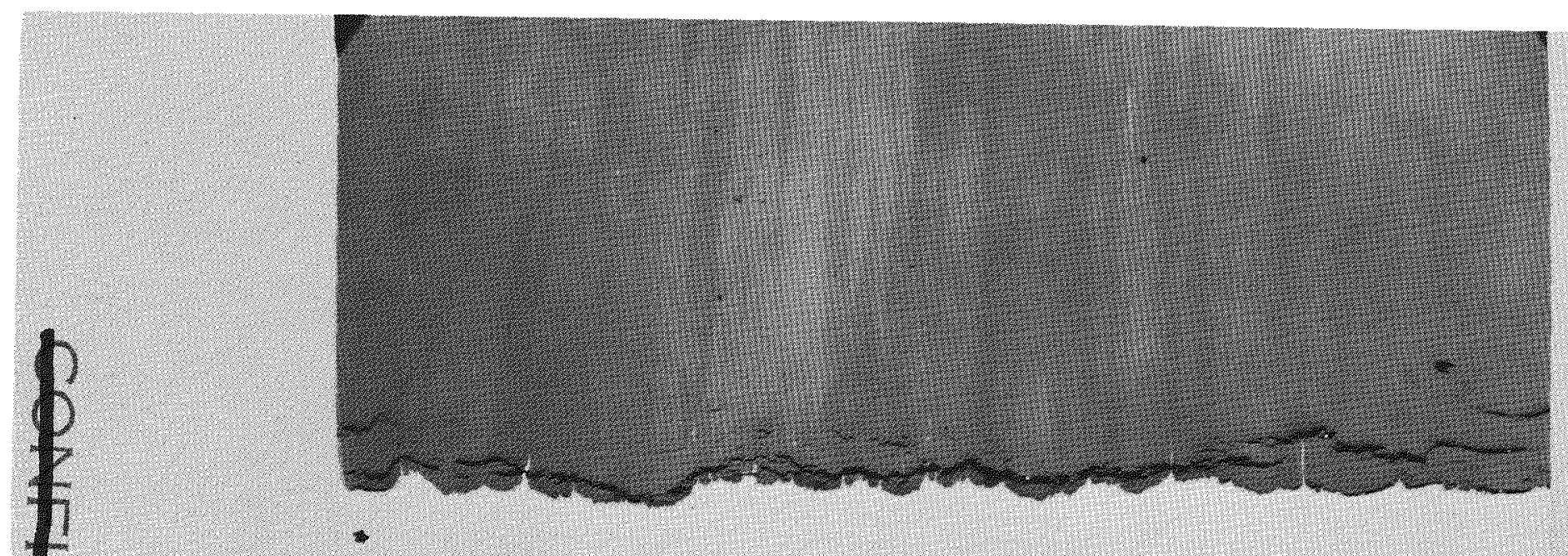

RIGURE 40

PLASMA TEST SPECIMEN T-1 POST TEST CONOITION

METALLOGRAPIY

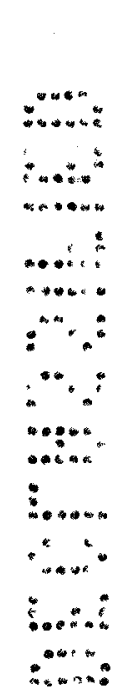

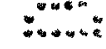

ino:

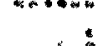

$\because \cdots$

$\because \because$

acos

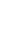

$\because \cdots$ $\because \cdots$

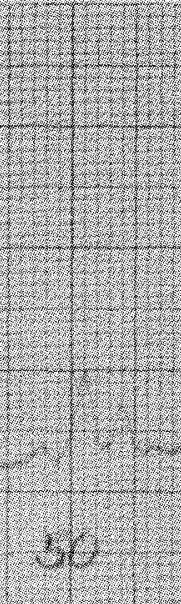

68 FIGURE 41

PLASMA TEST SPECTMEN T-1 POST TEST CONDITION X-RAY DIEFRACTION PATCERS 


\section{म)}

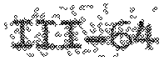

BNHADY 5670 BUT/LB

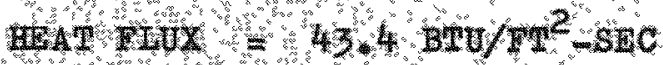

PRESURE

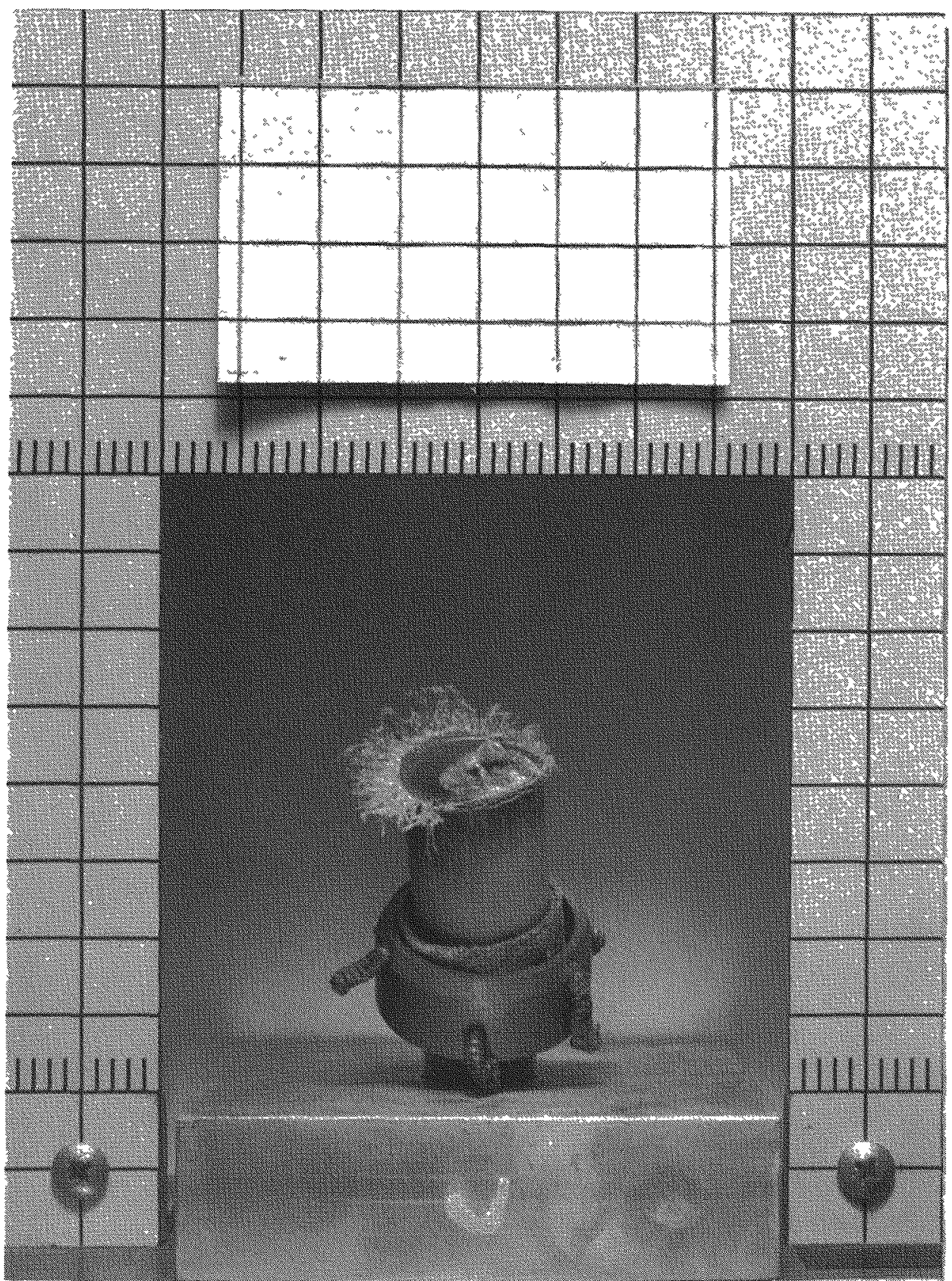

sond

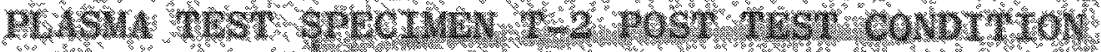

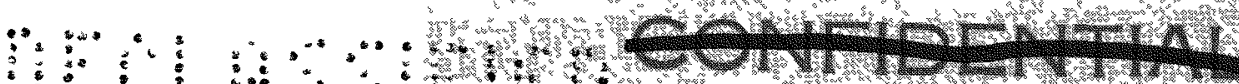




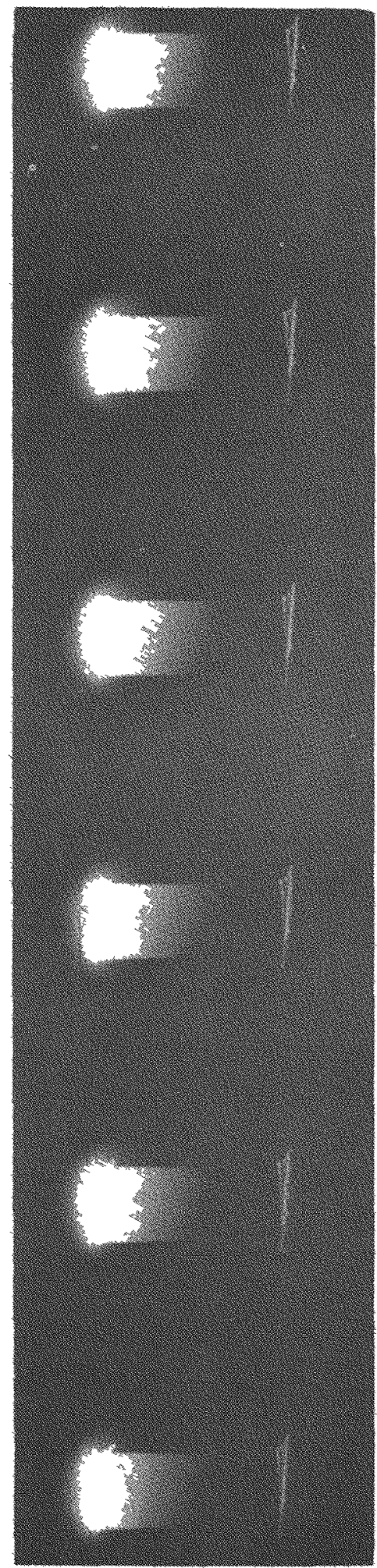

12 SECONDS AFTER INSERTION

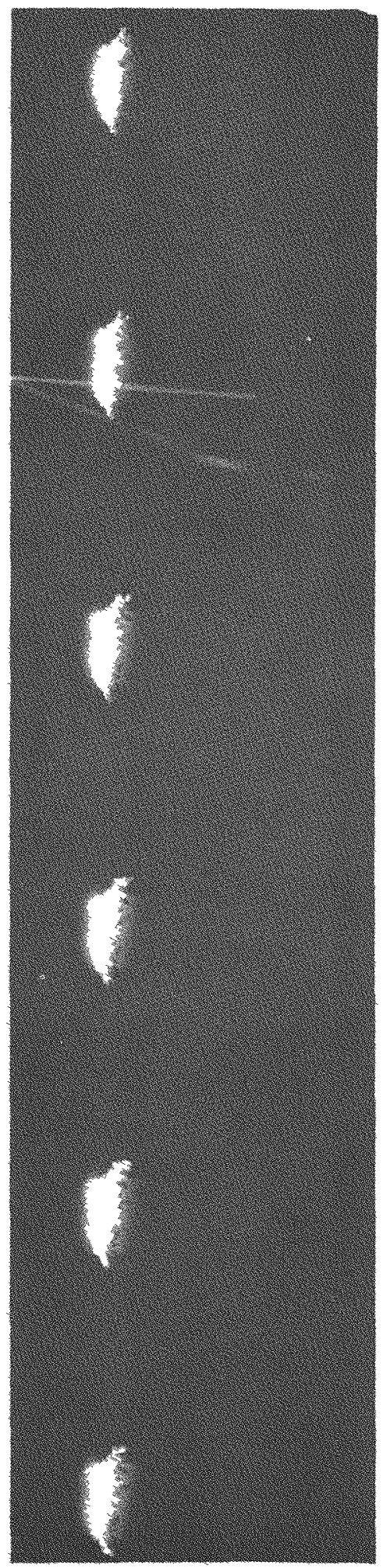

98 SBCONDS ATWER INSWRTION

$$
\begin{aligned}
\text { ENTHALPY } & =10,400 \mathrm{BLU} / \mathrm{LB} \\
\text { HEAT FLUX } & =127.4 \mathrm{BIU} / \mathrm{FT}^{2} \mathrm{SEC} \\
\text { PRESSURE } & =0.146 \mathrm{PSIA}
\end{aligned}
$$




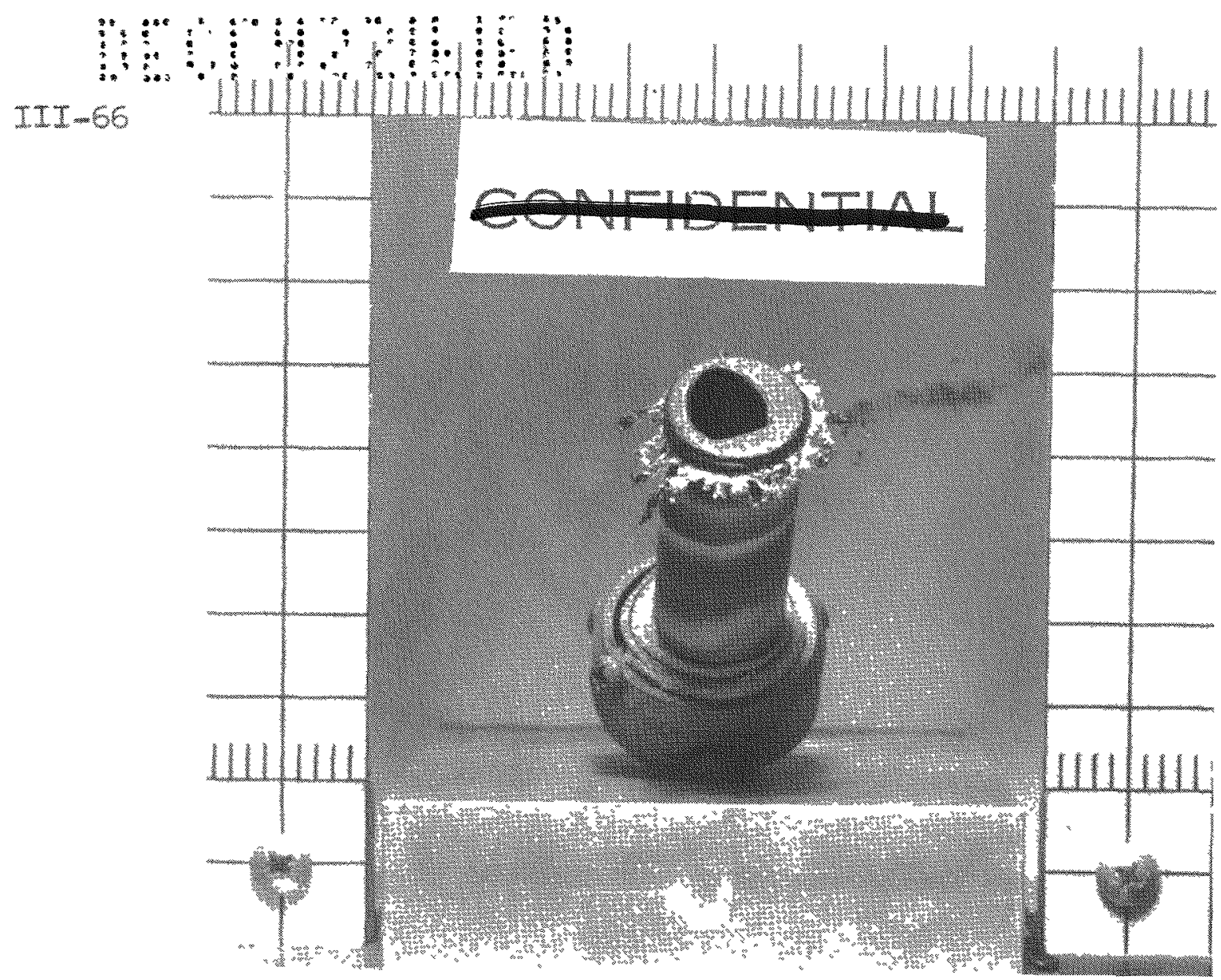

graURE 4

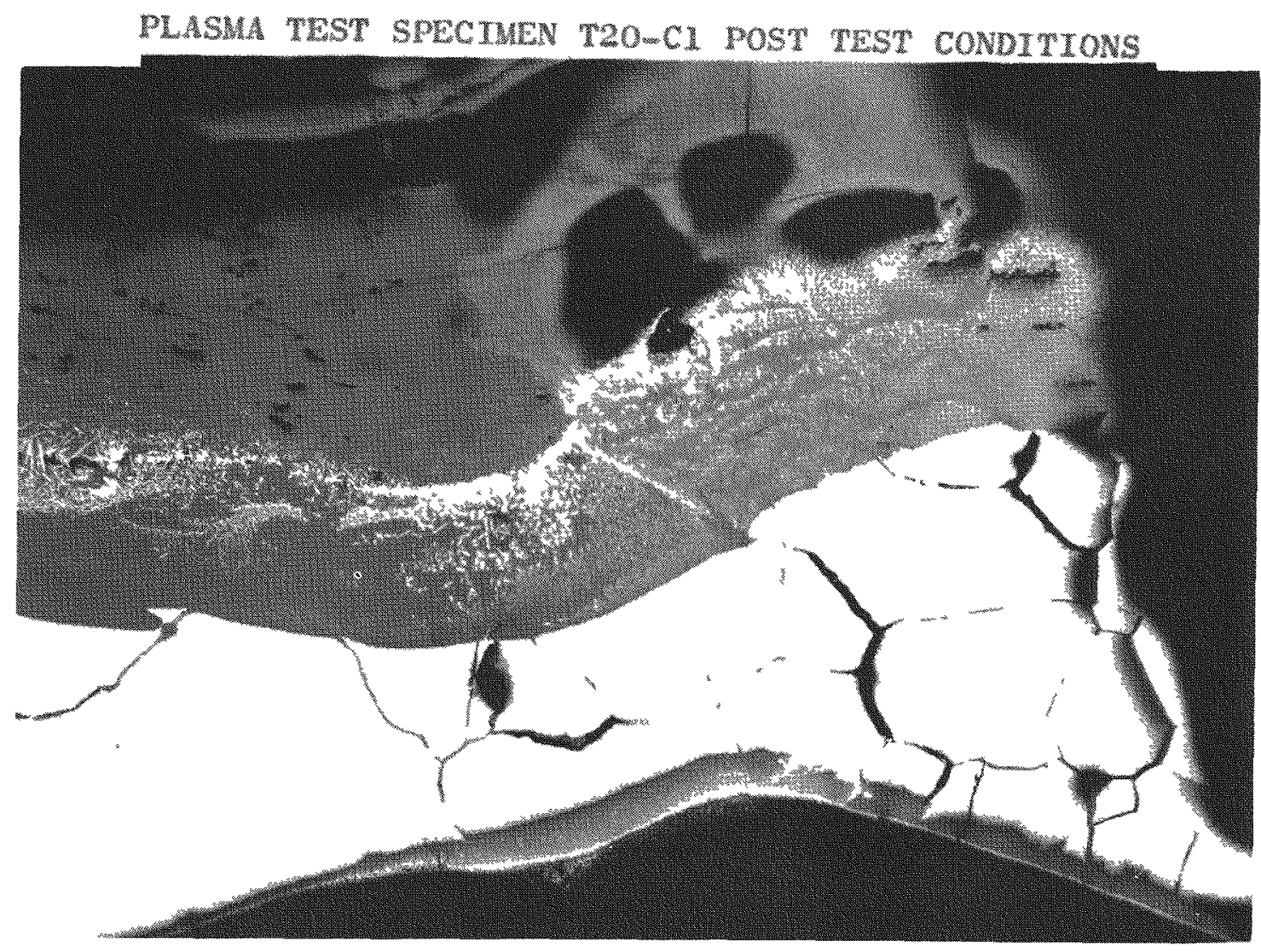

FTUURE 45

$10 \%$

PLASMA TEST SPECTMEN T20-CI POST TEST CONDTTIONS 

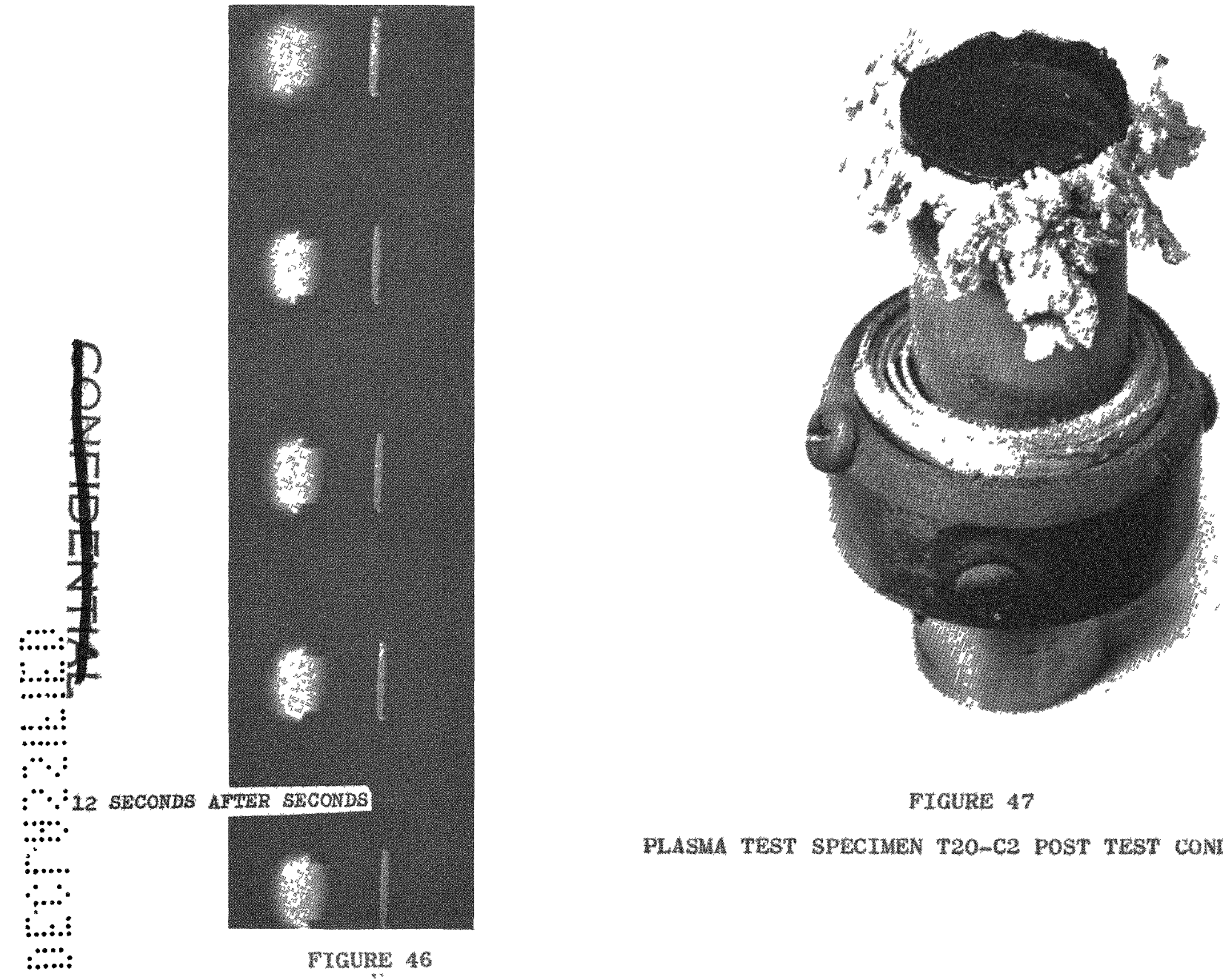

Pratre 47

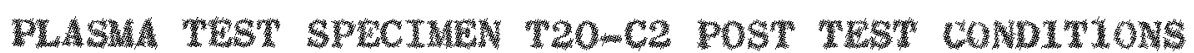

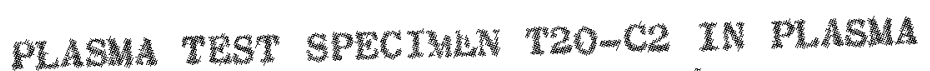




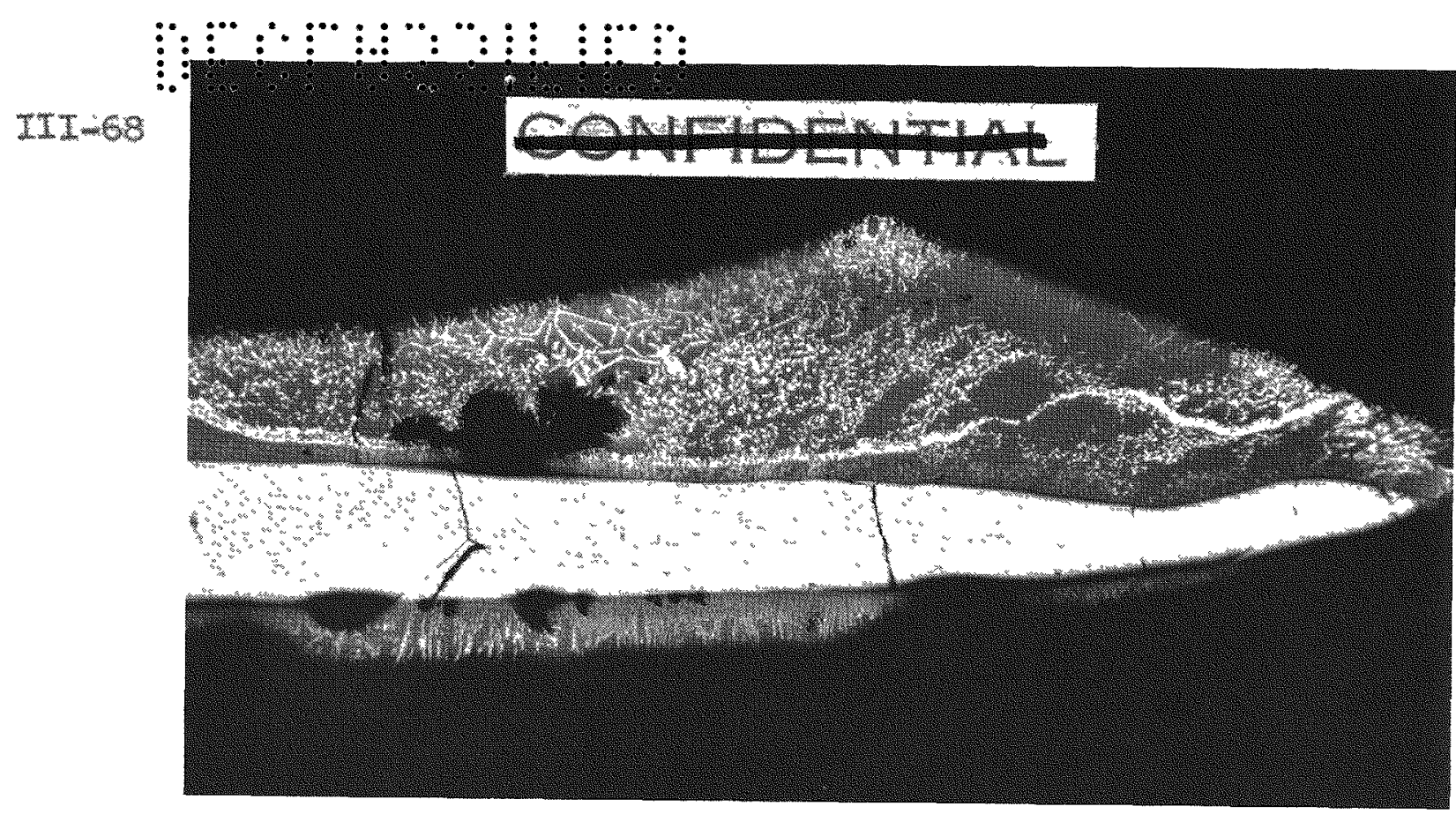

IGURE

rack

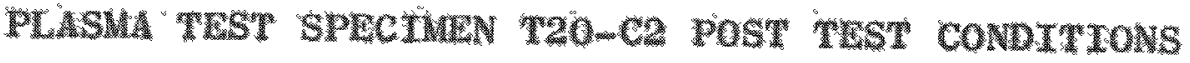
METALOCRAPUY

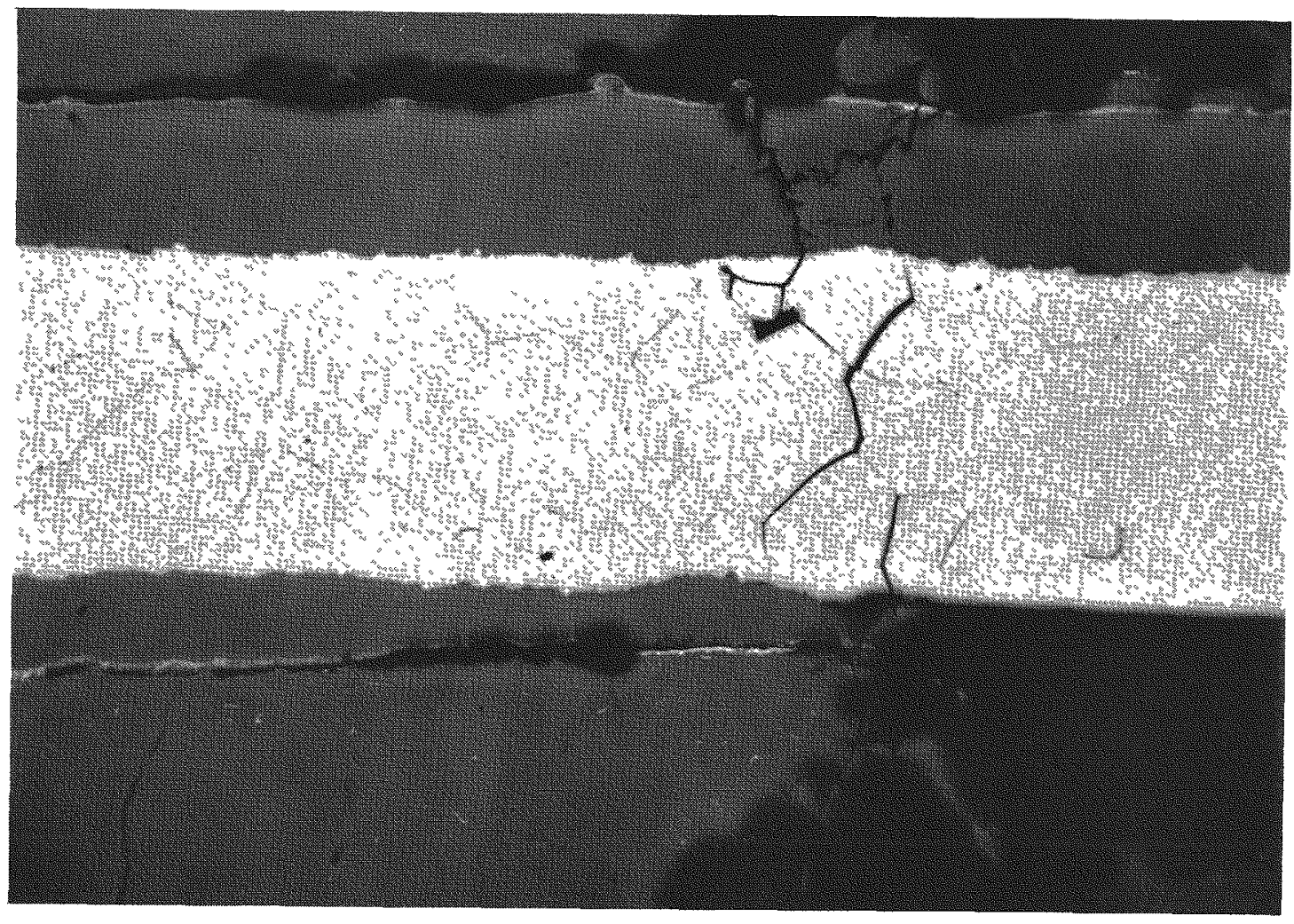

Fringes

106

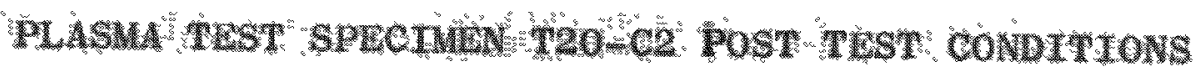

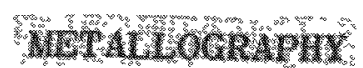

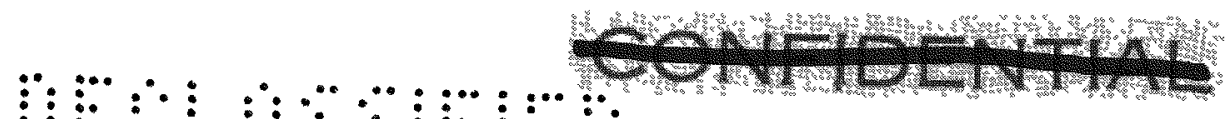

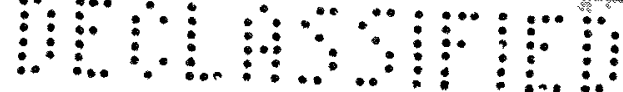




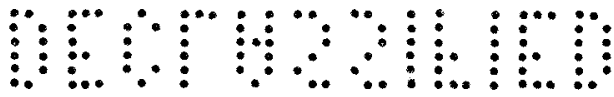

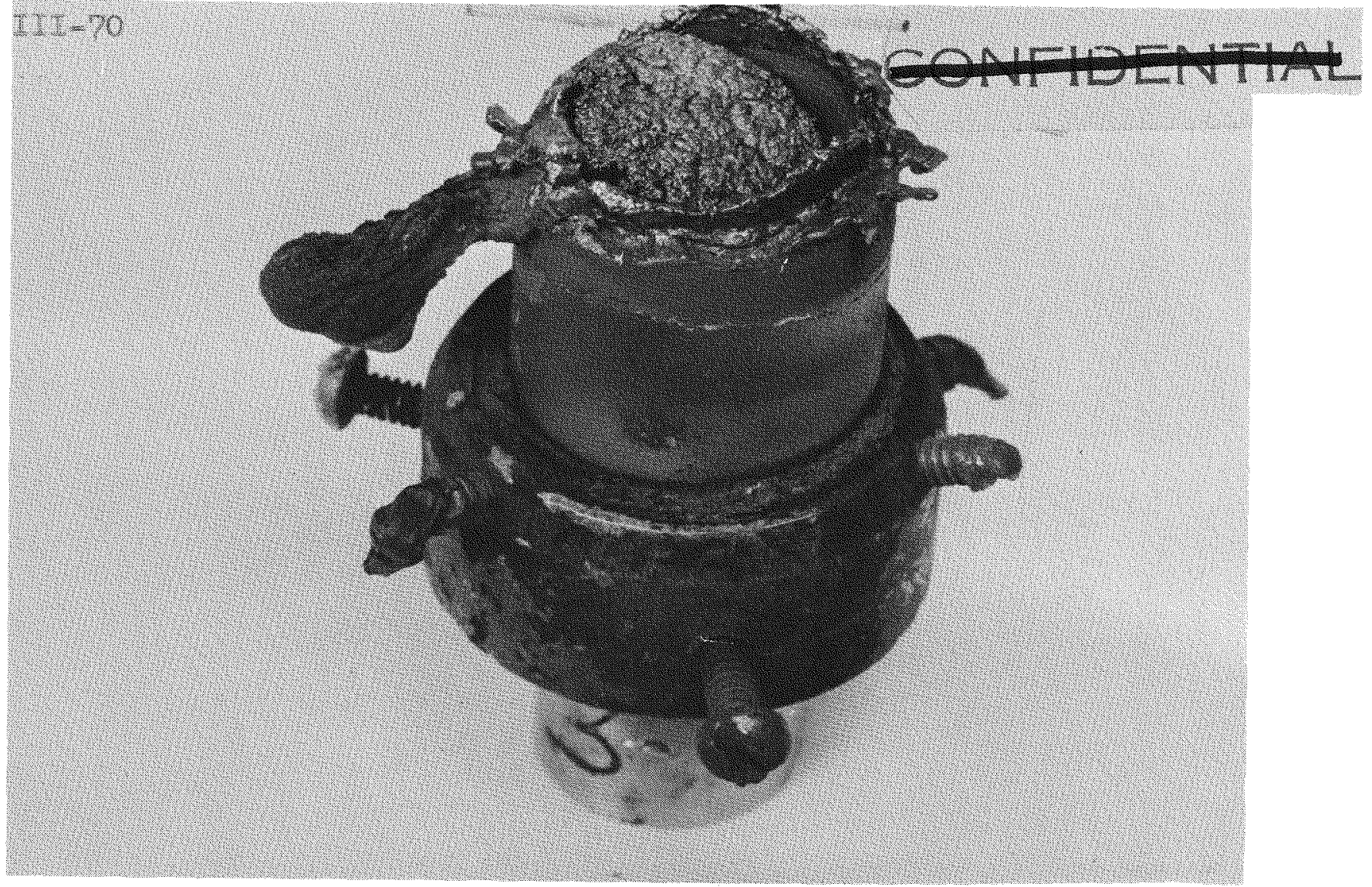

FIGURE 52

PLASMA TEST SPECTMEN FHT-1 POST TEST CONDITION

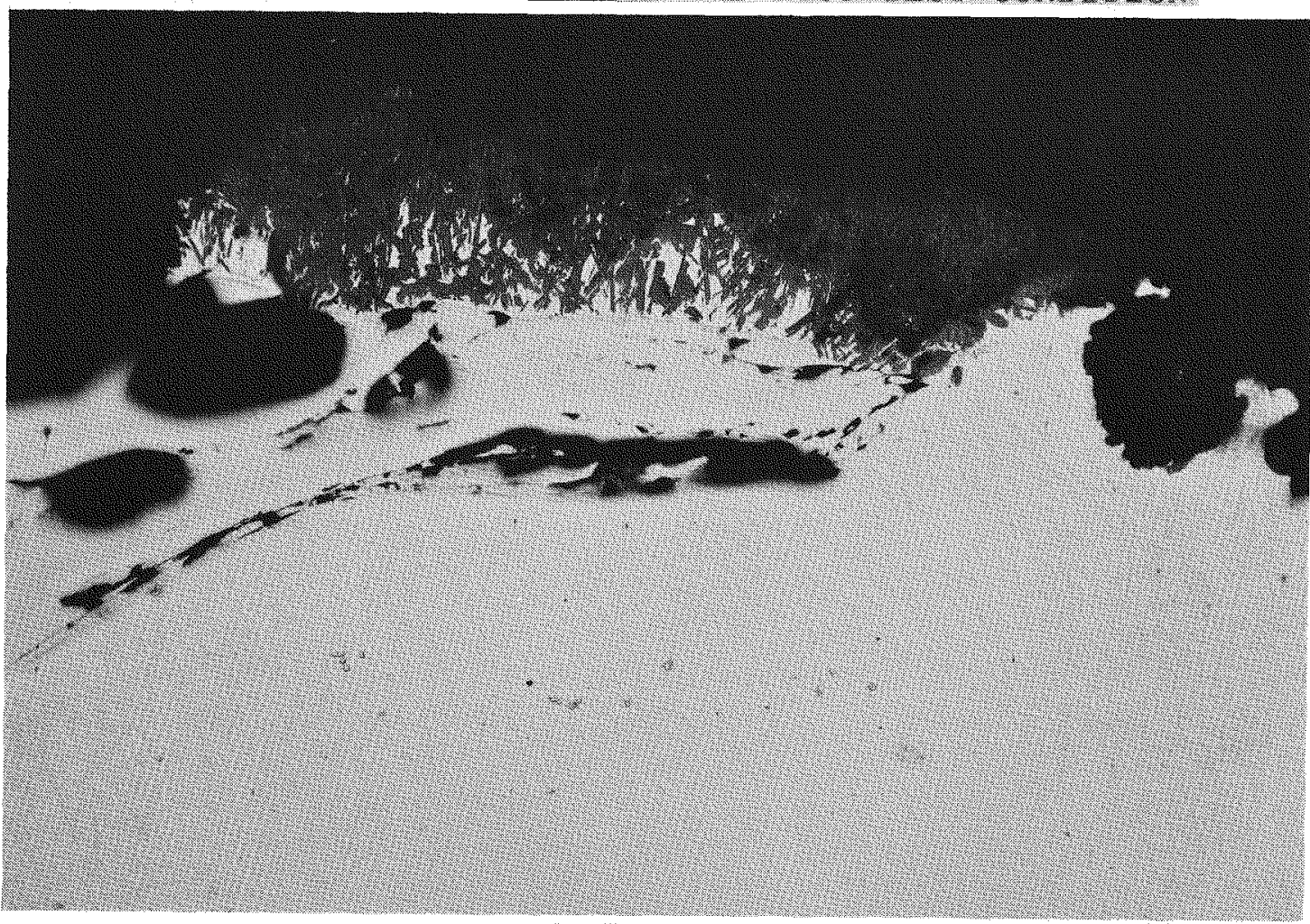

PIGURE 53

PLASMA TEST SPECIMEN FHT-1 POST TUST CONDITION

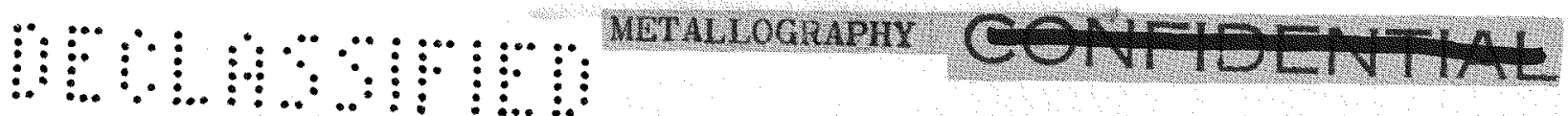




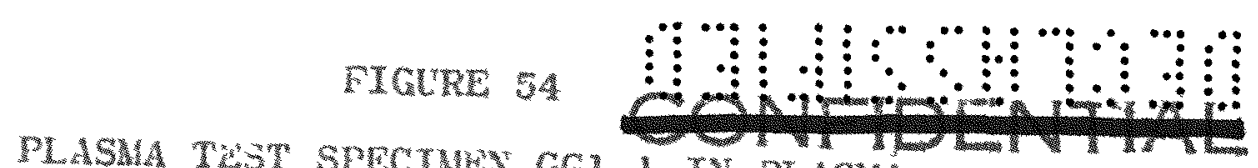

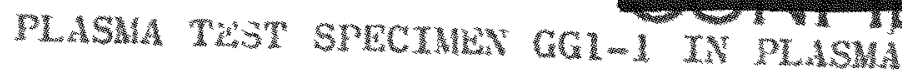

III 11

130 SECONDS AFTER MODEL

INSERTION INTO PIASMA
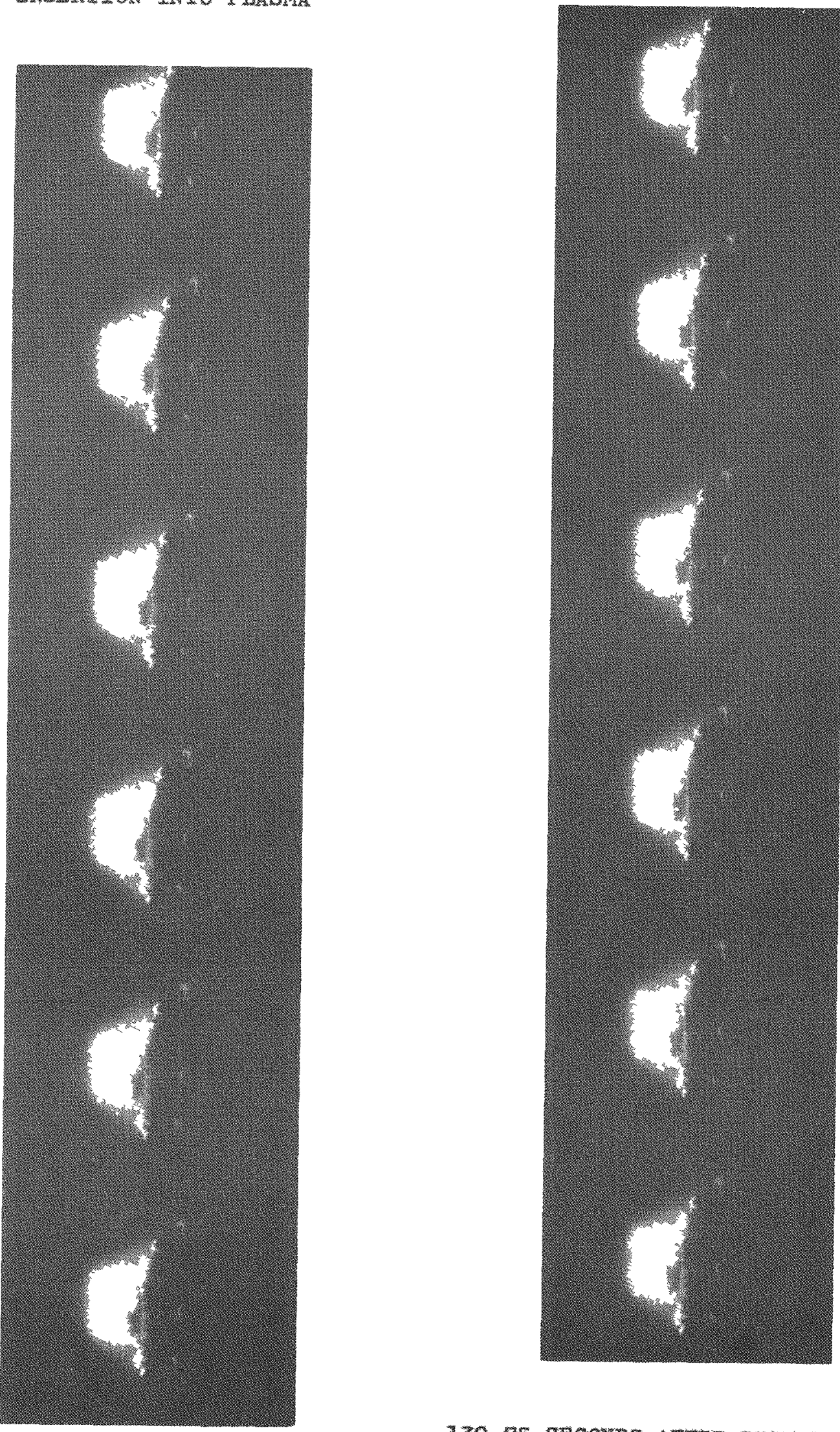

130.75 SECONDS APTER INSERTON

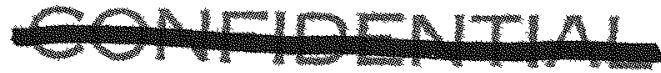


$\because \cdots$.

$\because \cdots$

$\because \because$.

:.."

$\therefore .$.

…....

......

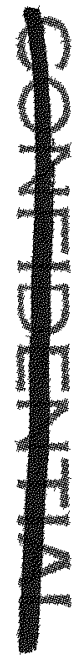

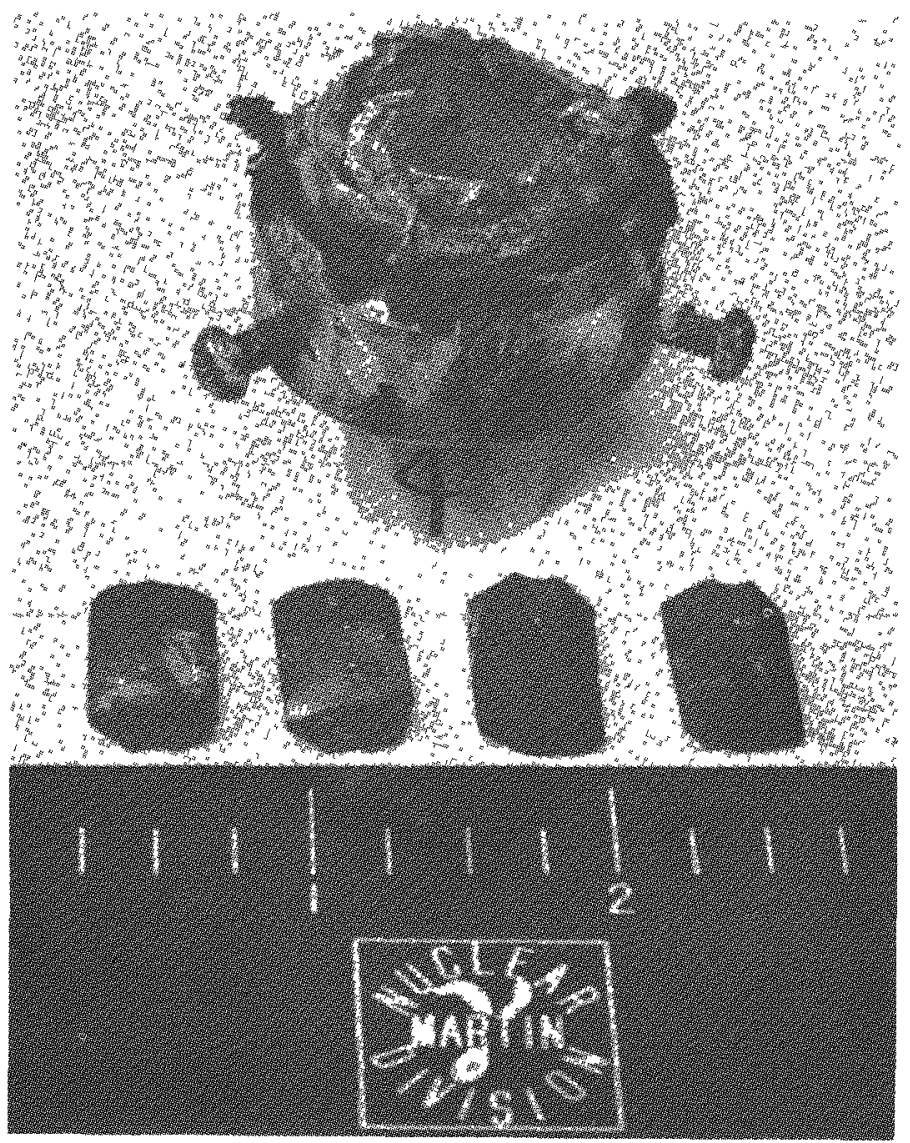

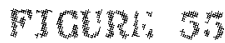

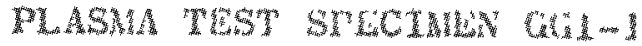

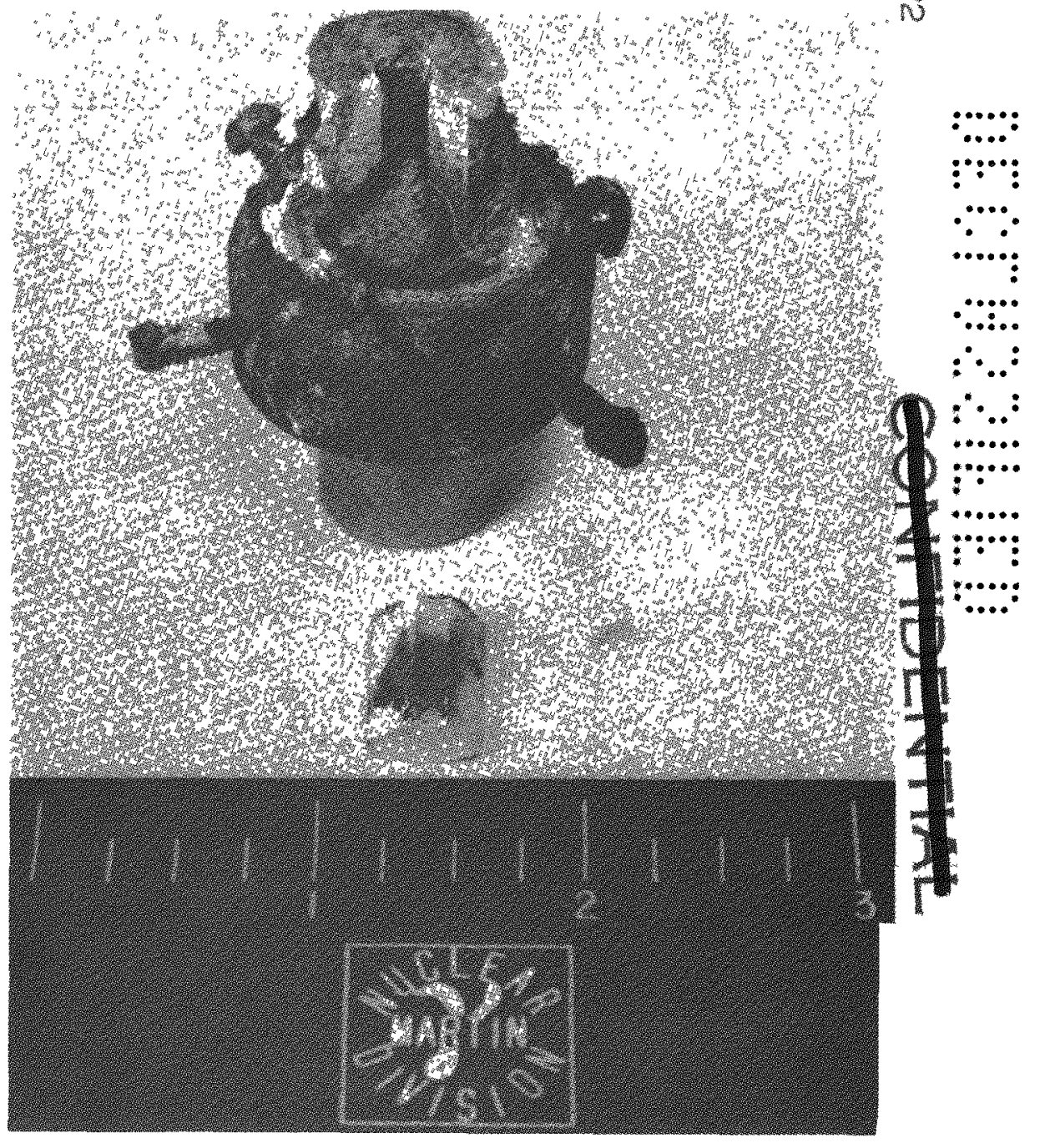

Frowris

WLASMA TES STHCHAN GBN-1 


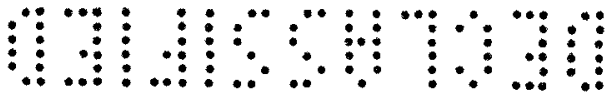

\section{COATHTH}

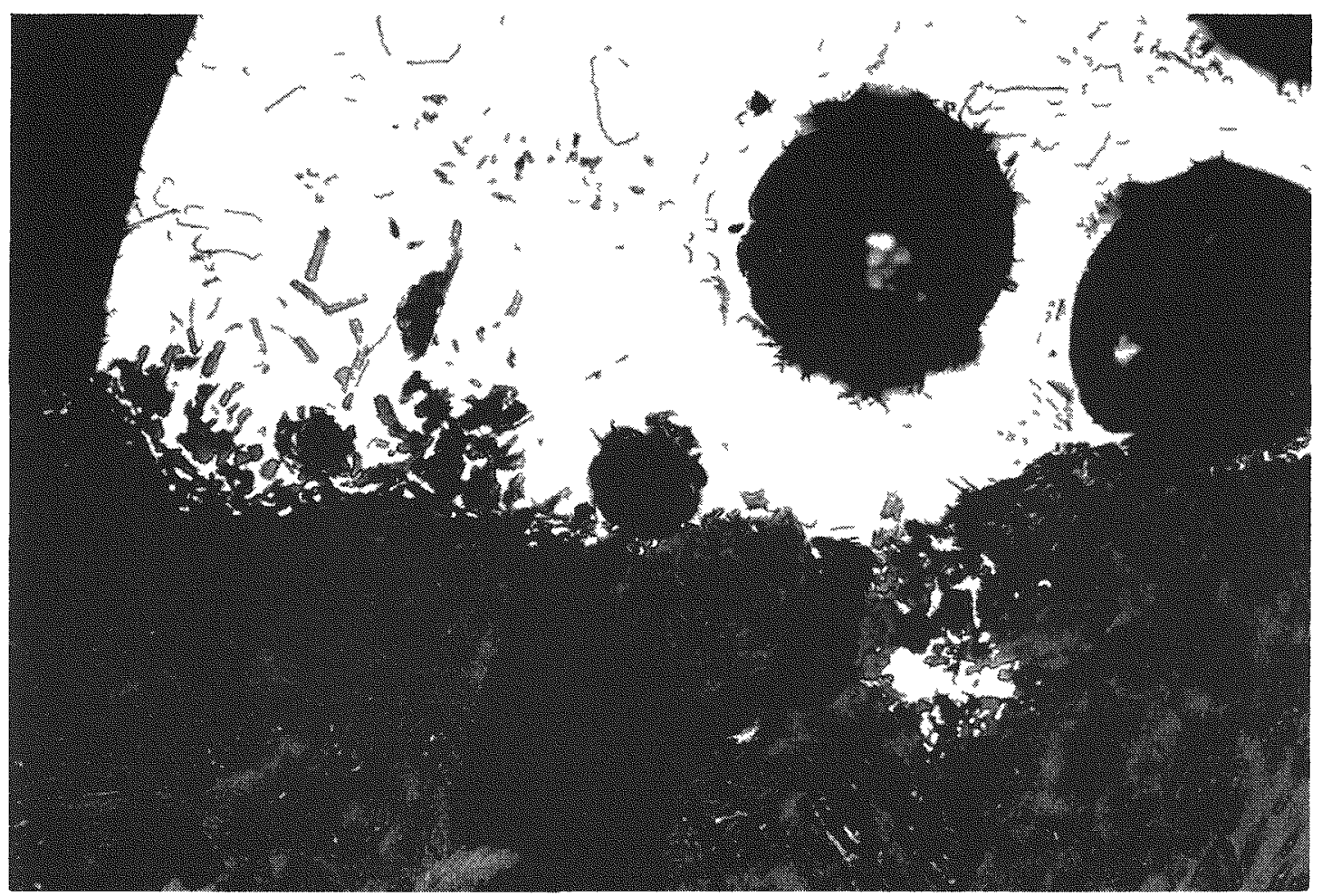

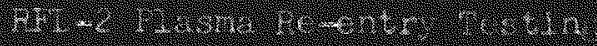

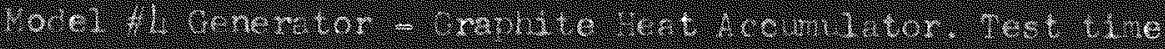

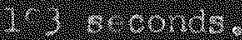

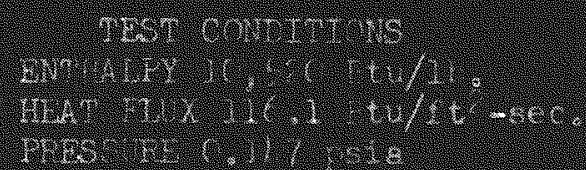

(1)

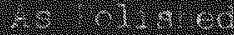

(2)

FTGLRE 57

PLASWD TEST SPECINEN GC1-1 POST TEST CONDITION 


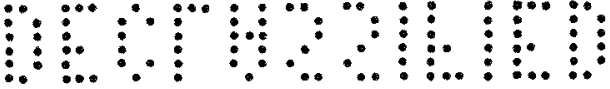

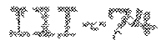
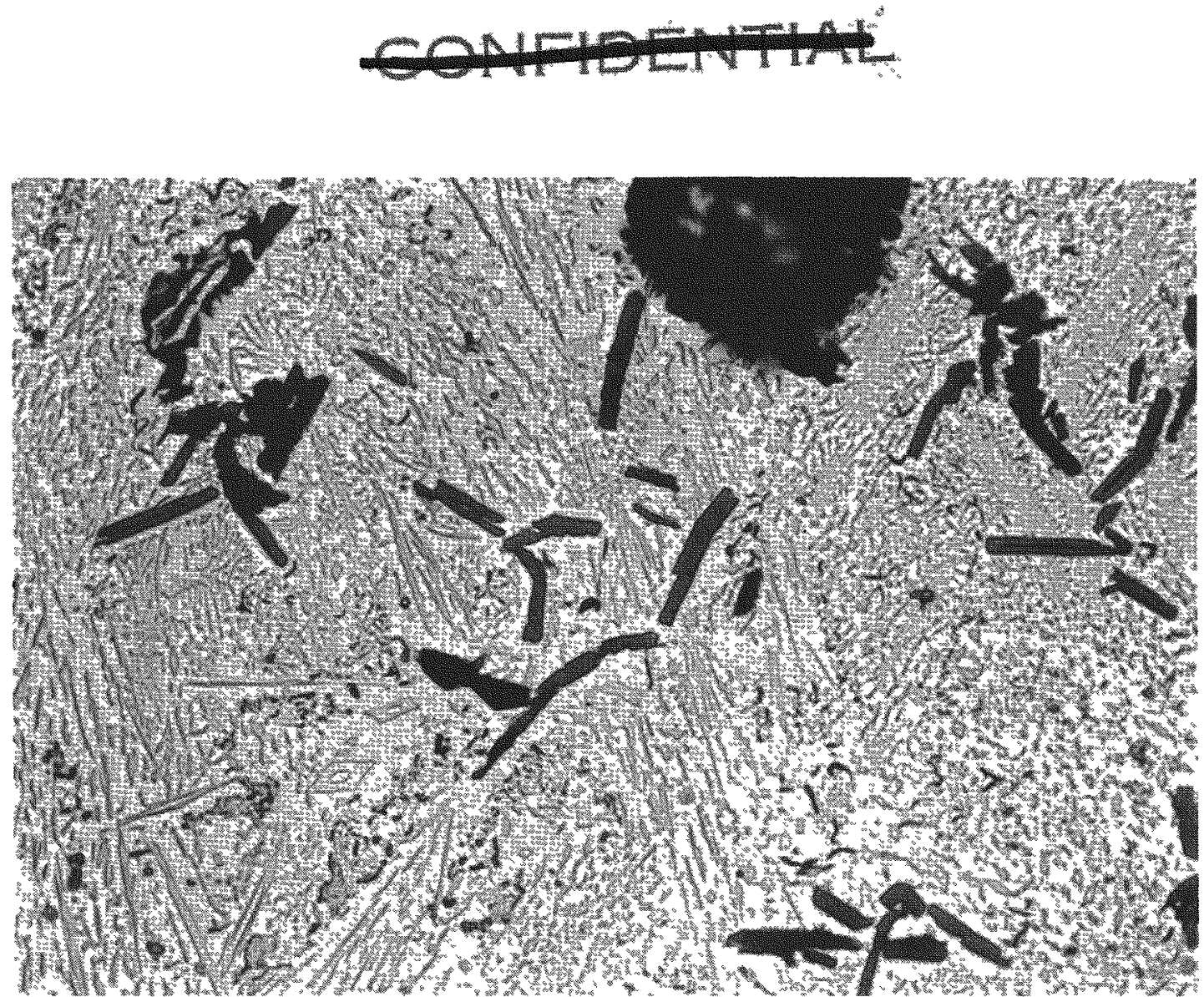

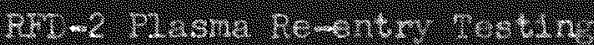

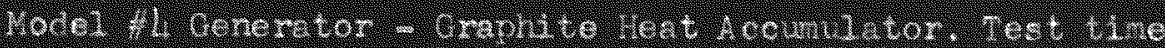
IS3 reconde.

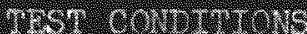

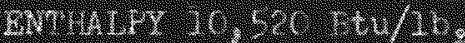

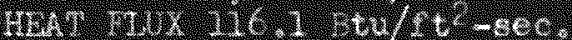

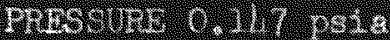

M. -15356 N-12635
As relsiked

6. oct. 63

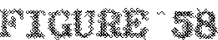

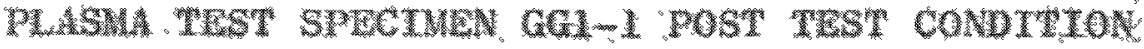




\section{आA}

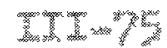

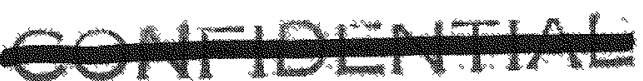

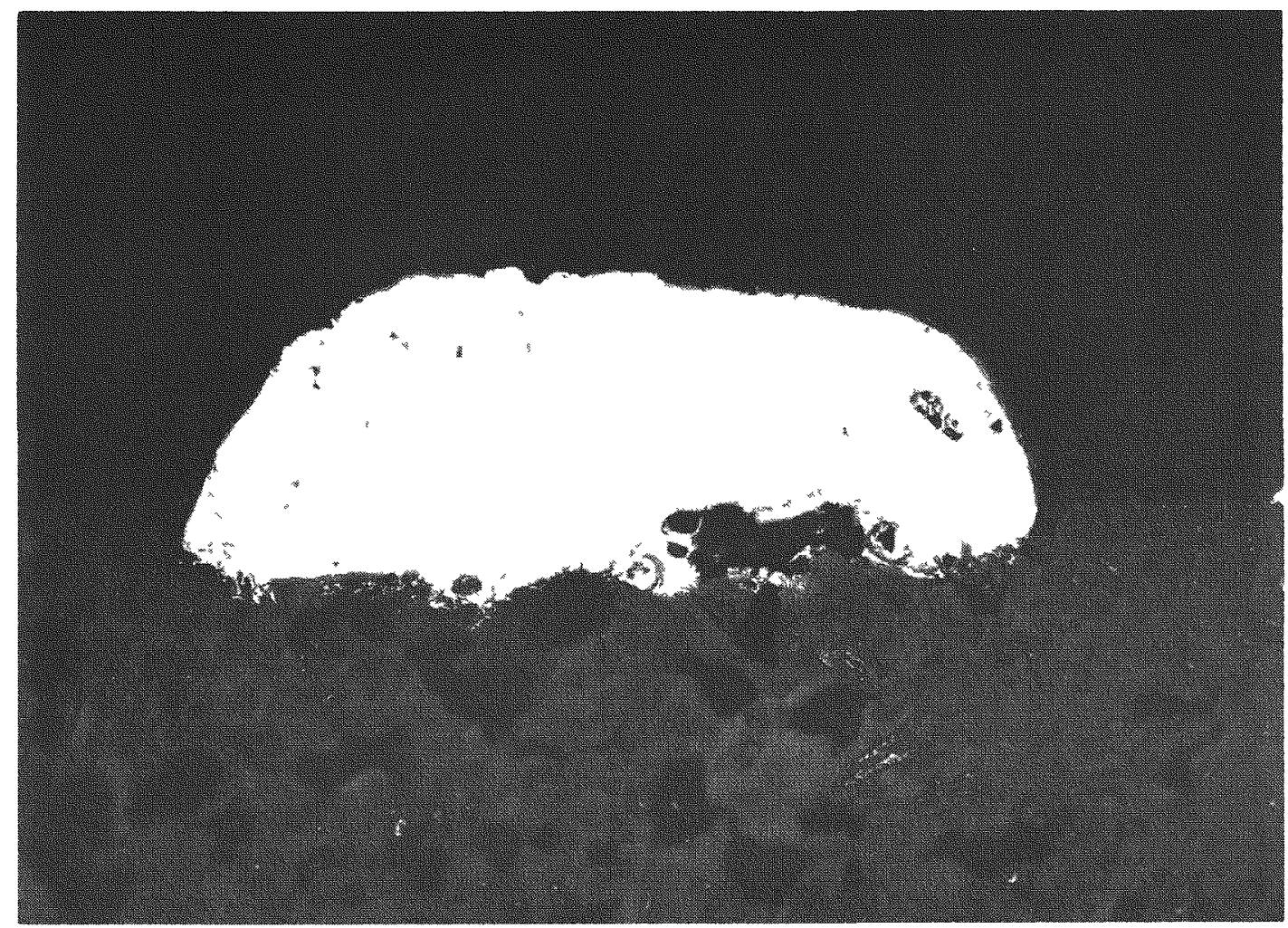

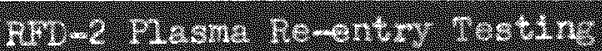

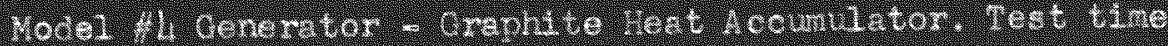
$1 \mathrm{cs}$ seconds:

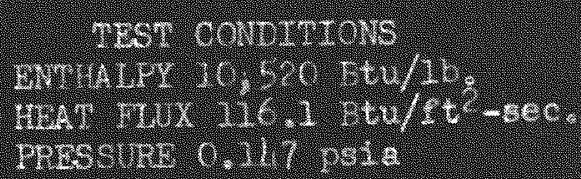
$47,3,3,6$

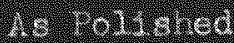

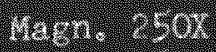

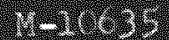

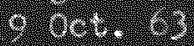

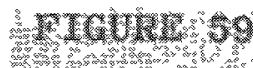

"RLAM"

At

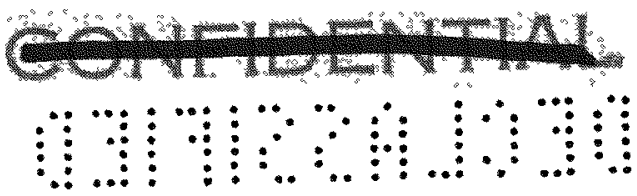




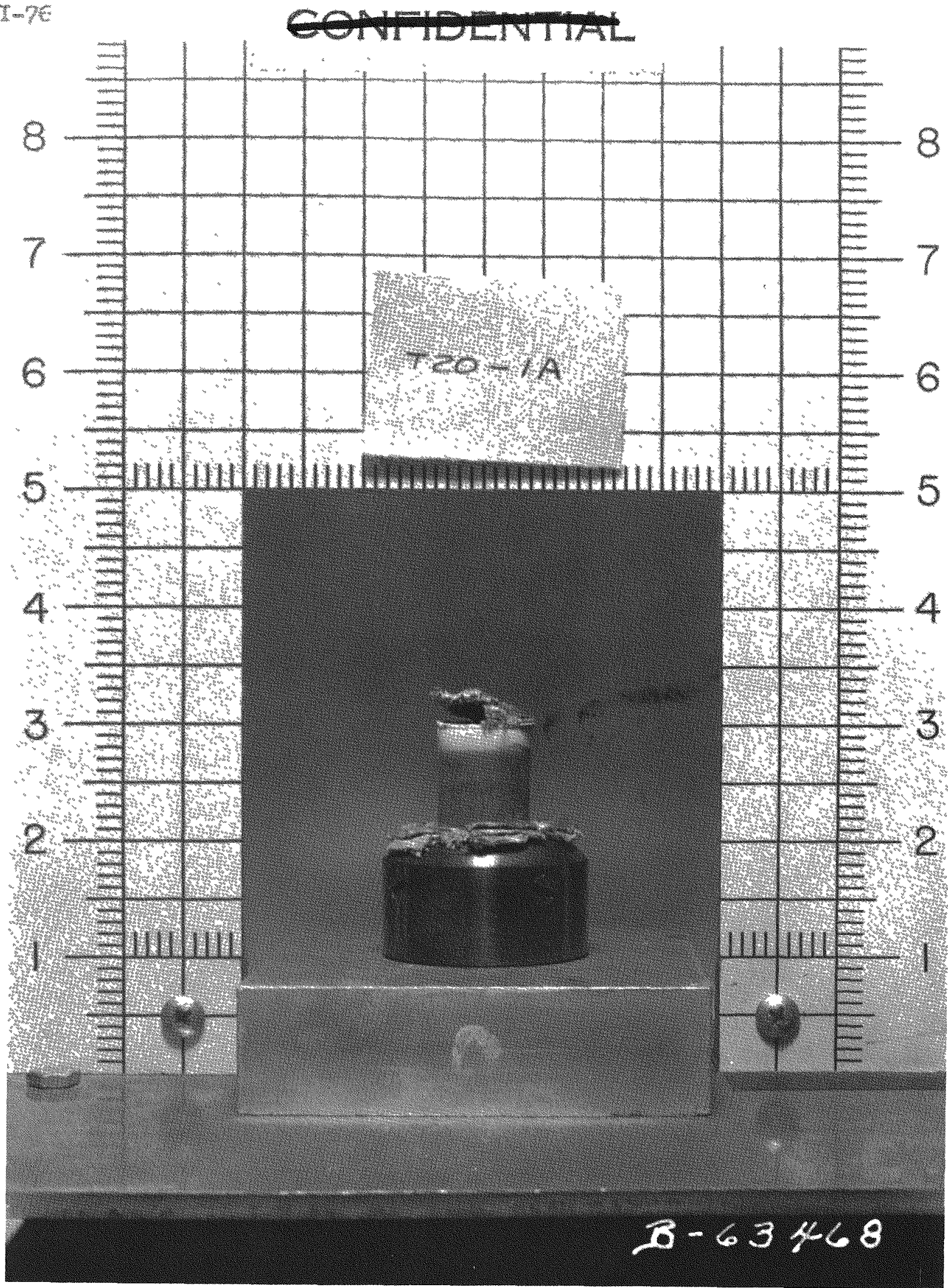



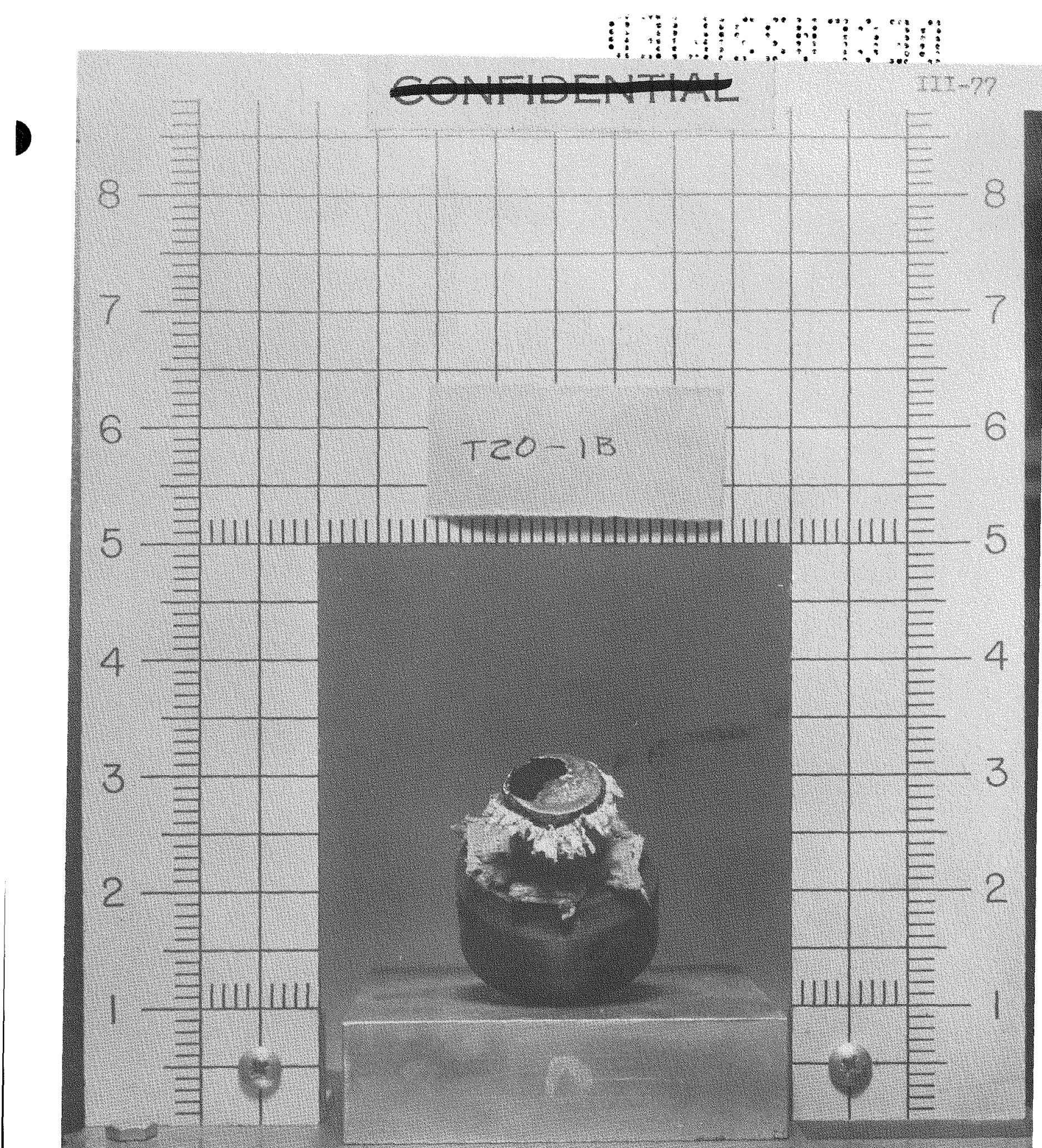

$$
3-63+65
$$

FrTGURE 61

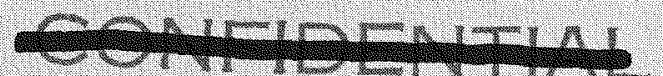

PLASMIA TEST SRECIMEN T20-1B POST TEST CONDITION 


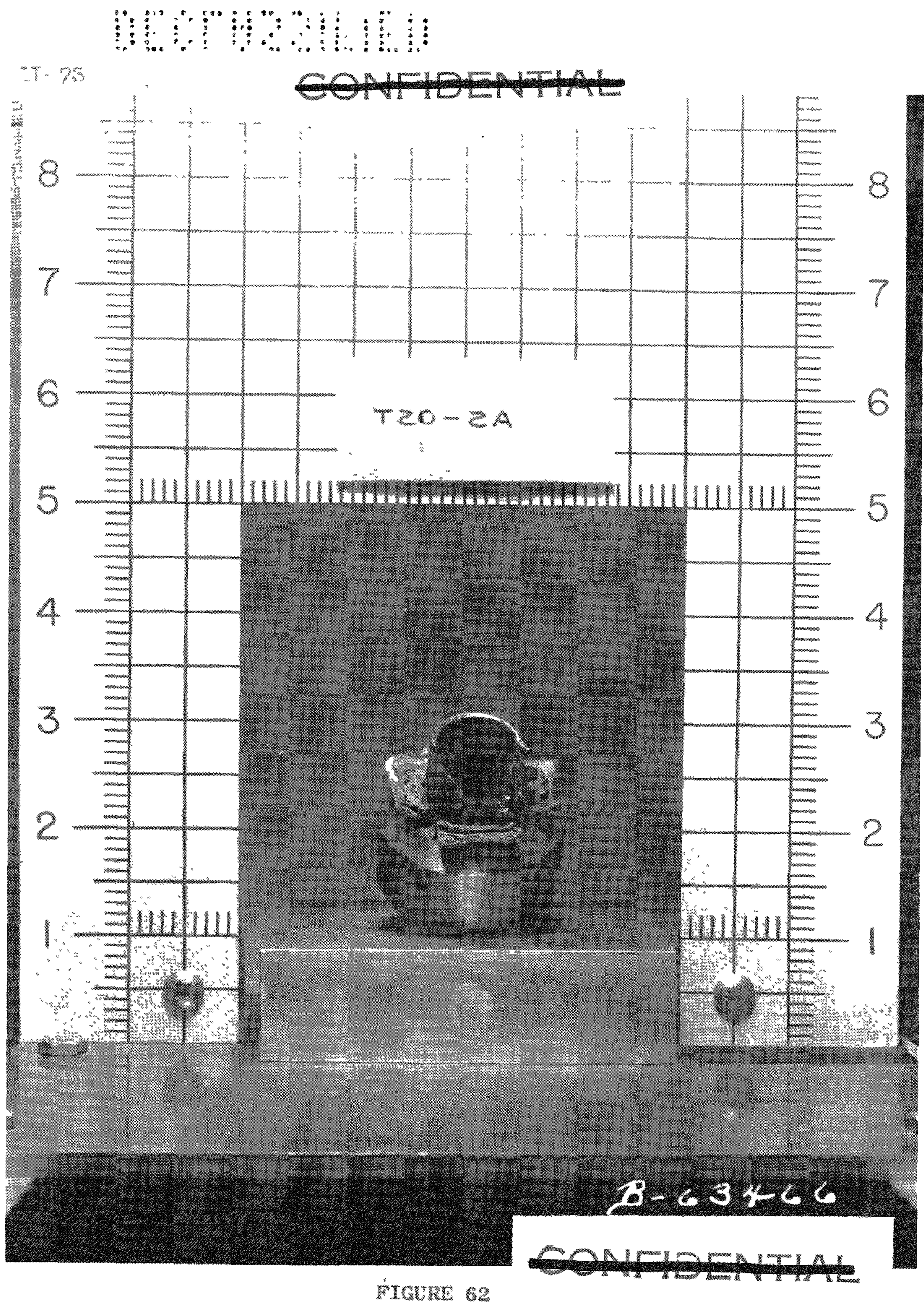

PLASMA TEST SPECTMEN T2O-2A POST TEST CONDITION

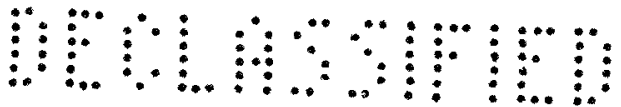




\section{ॠ!}

; 


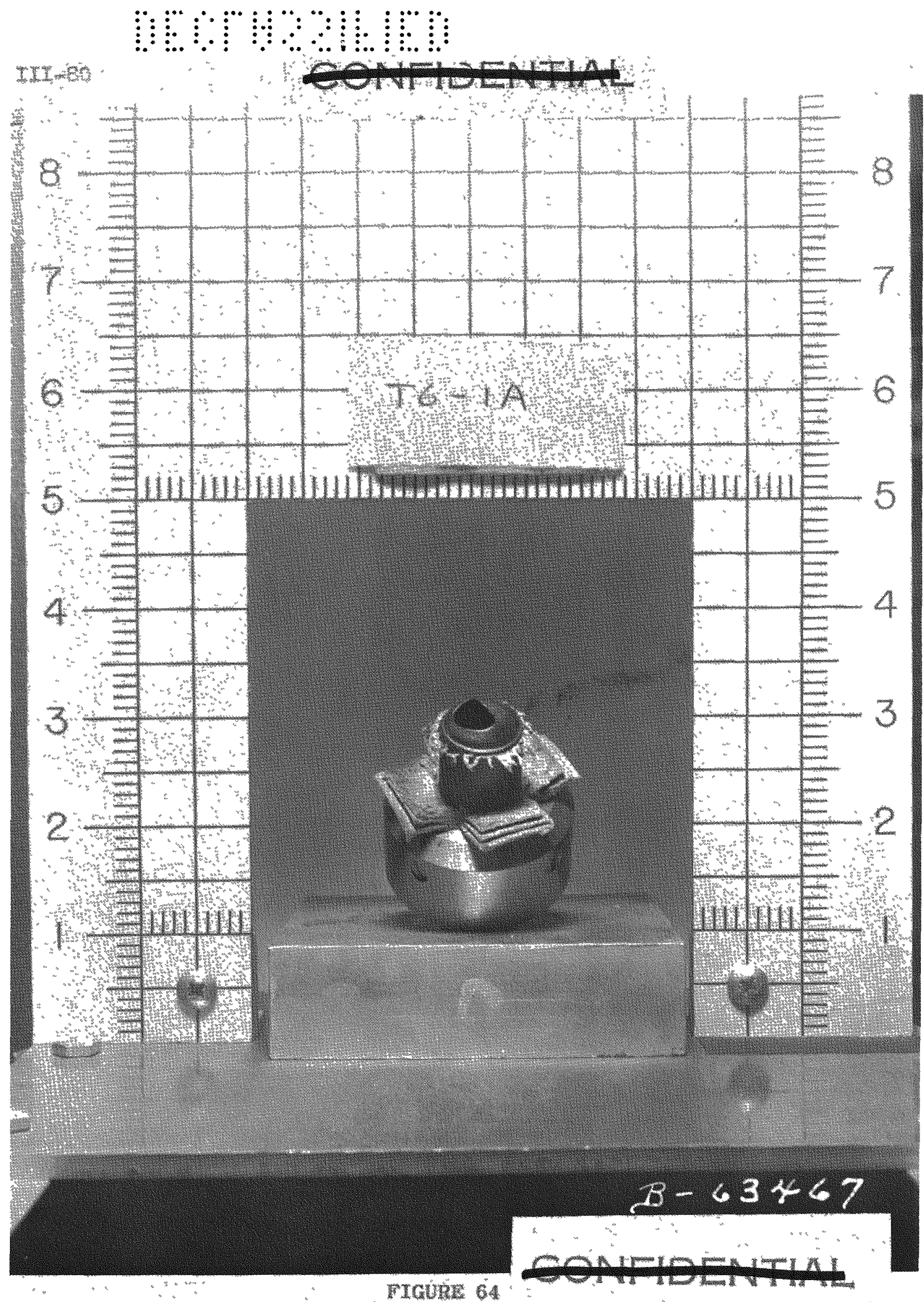




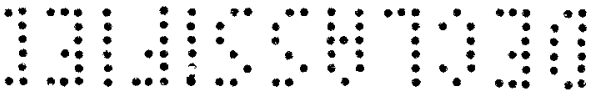

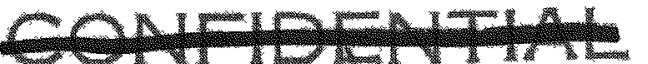

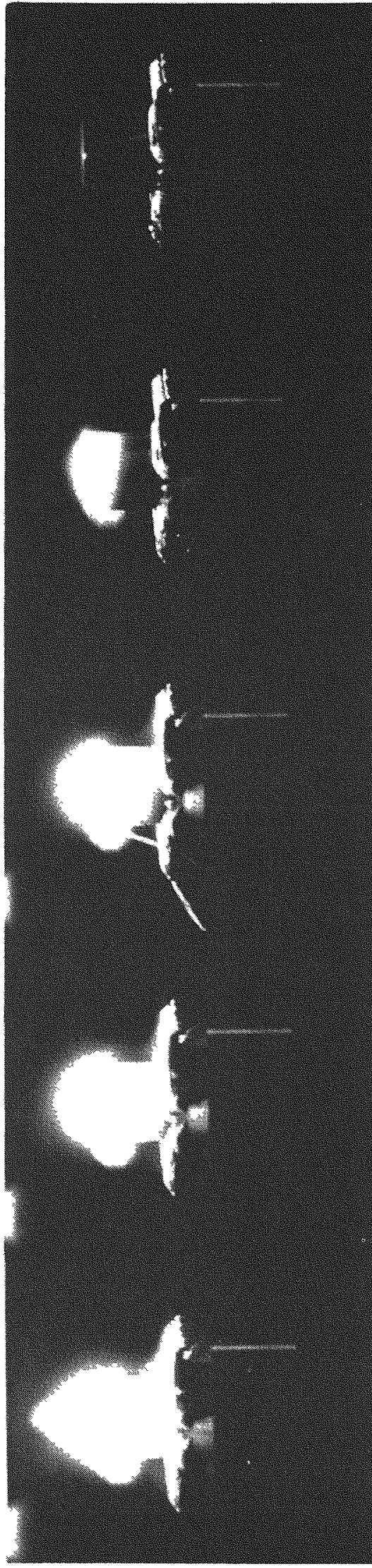

12.87 SECONDS

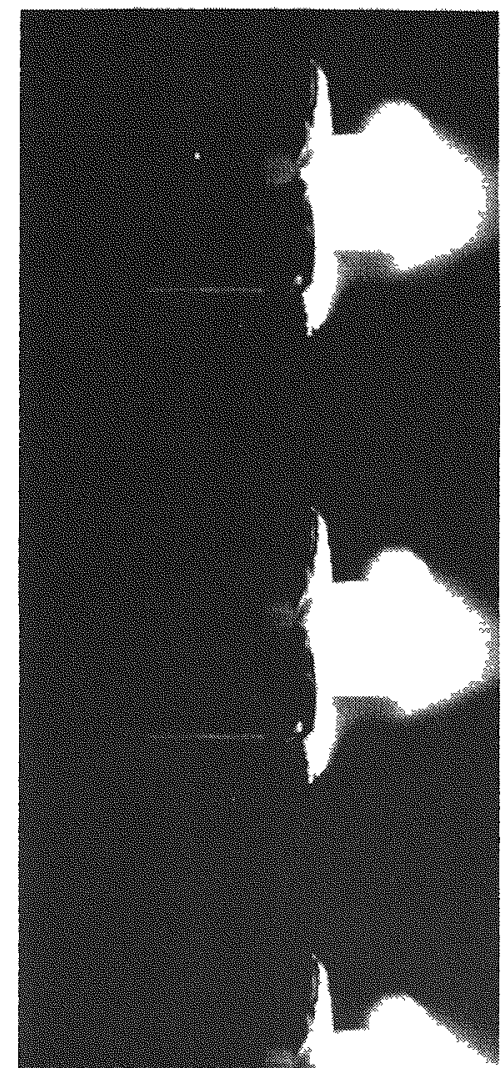

L

5.72 seconos

$$
7.12 \text { swconds }
$$

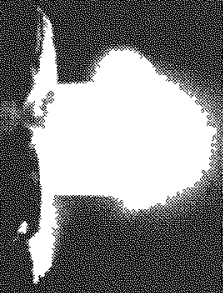

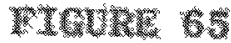

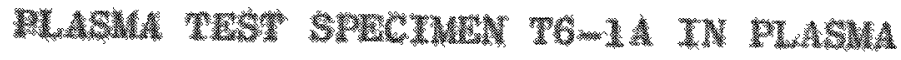




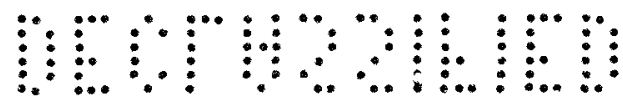

I.

รX)

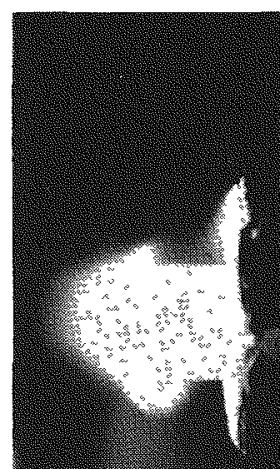

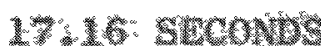
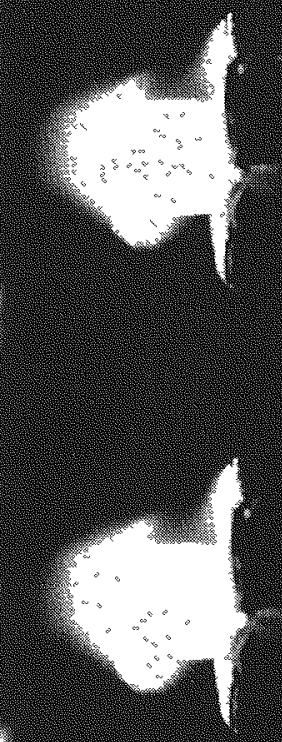

Cron

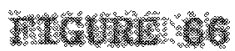

puswita 

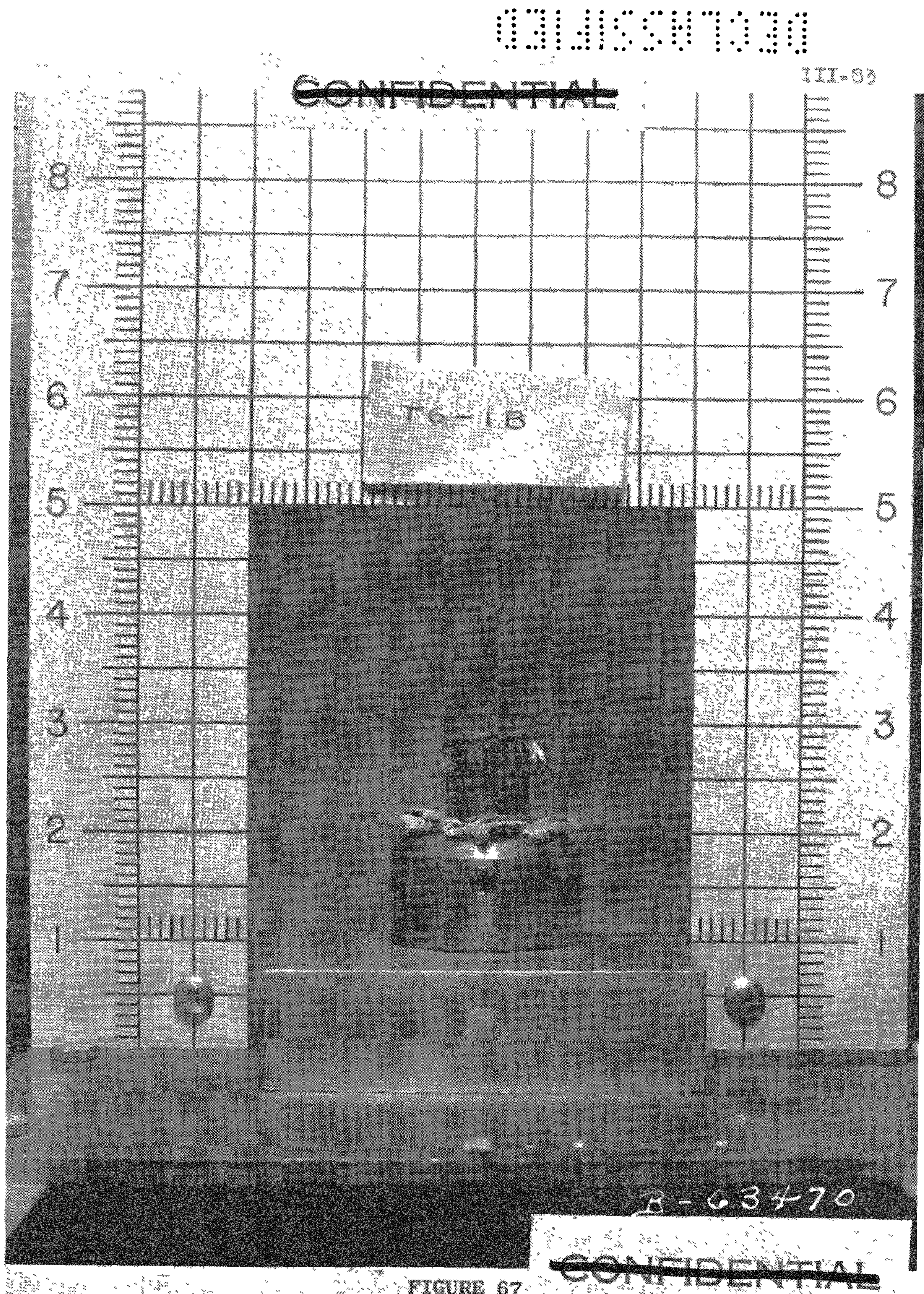

FaUn?

W. 


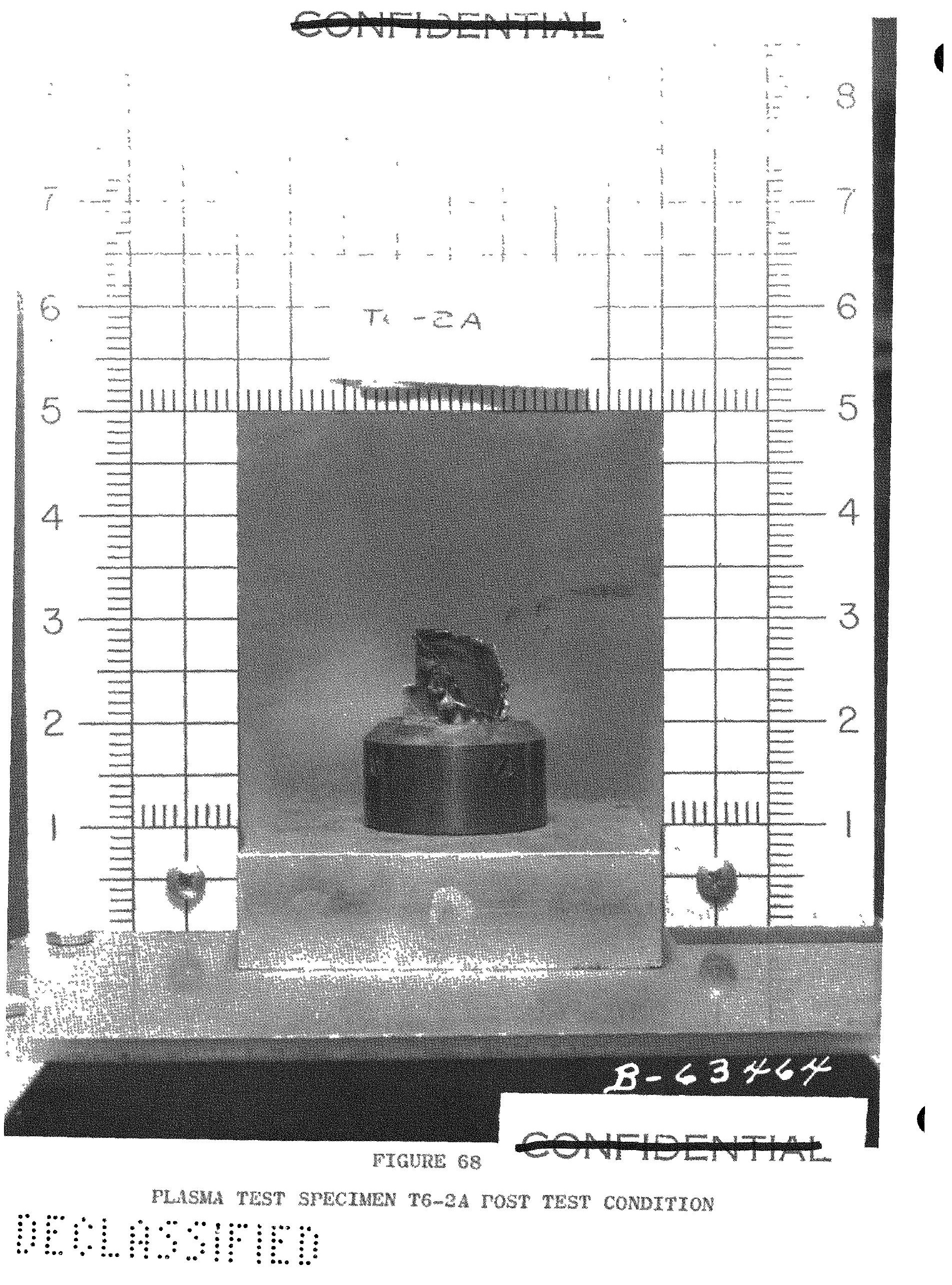




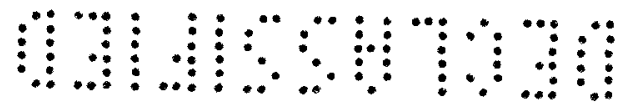

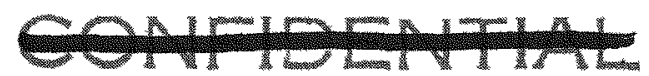
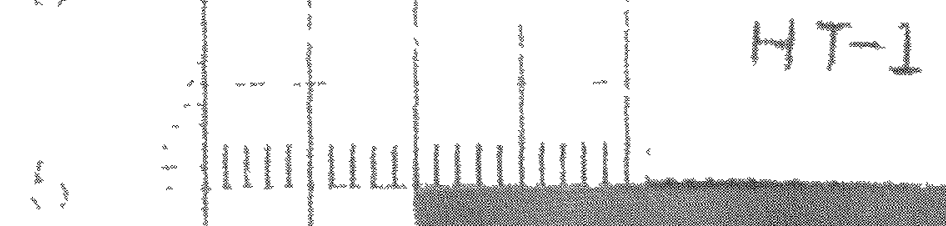

4

2

3
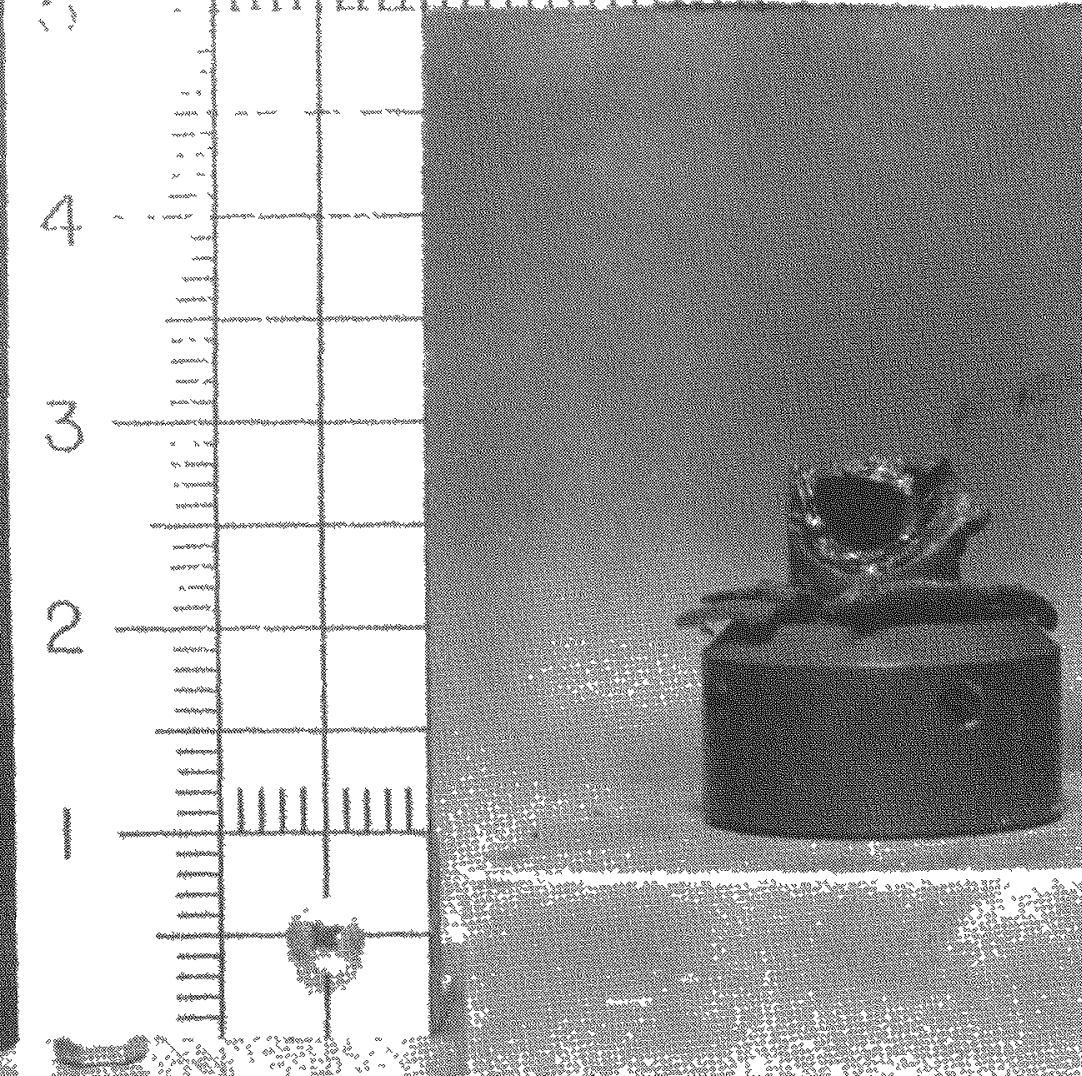
1.1) 1411114

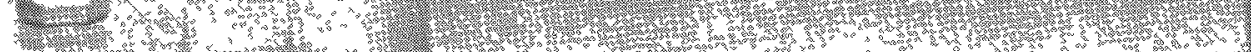

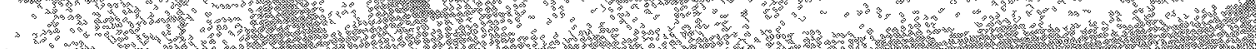
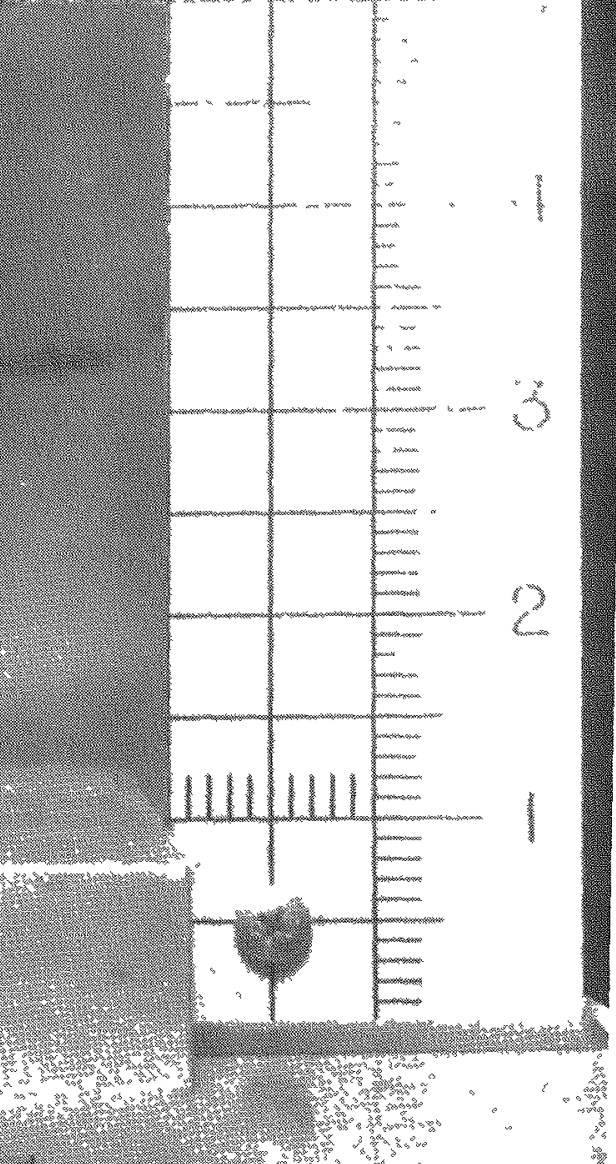

\section{$8-65420$}

MaURE 69

PLASMA TEST SPECIMEN ITT-1 POST TEST CONDTTION 

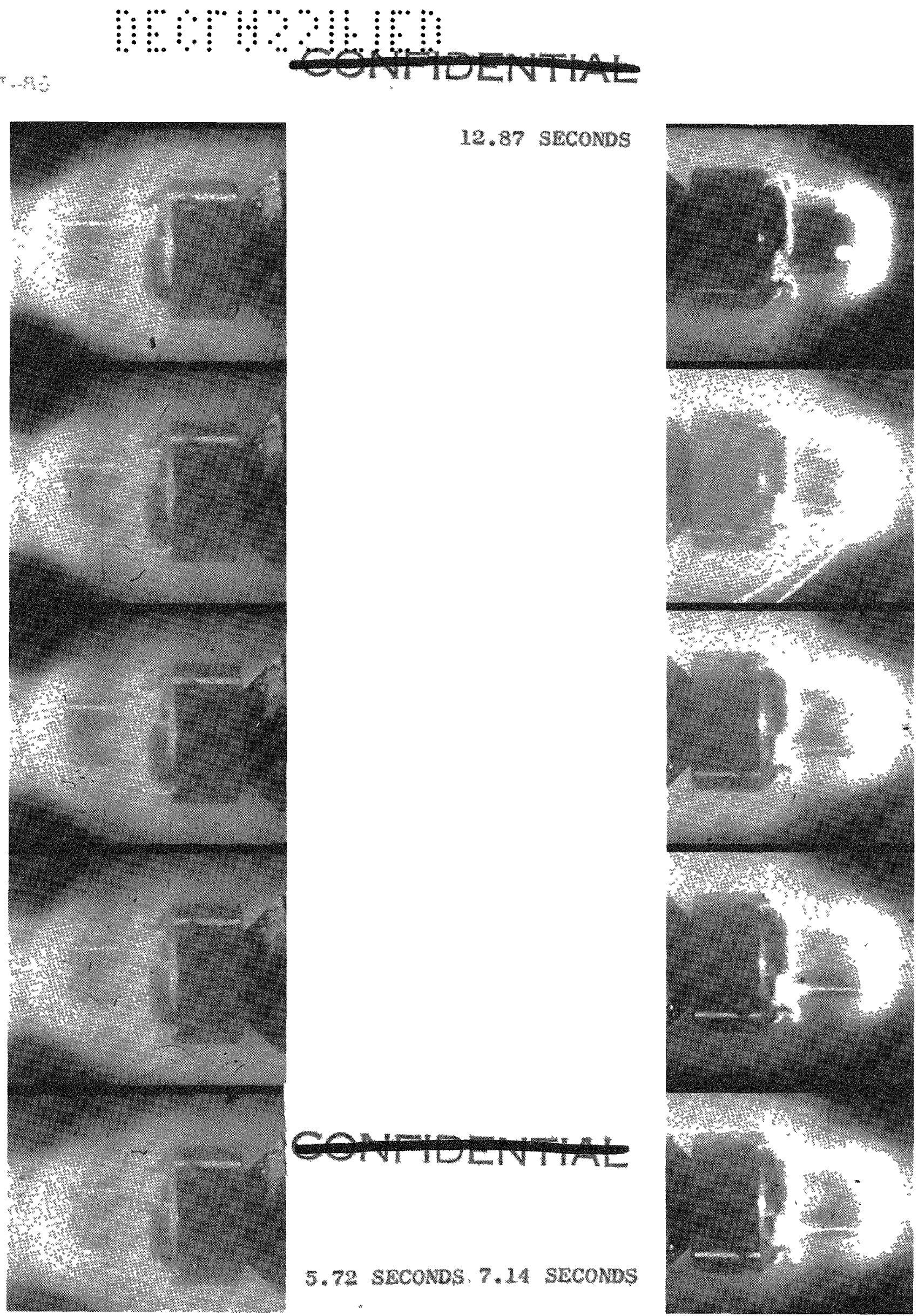

FTCUne 70

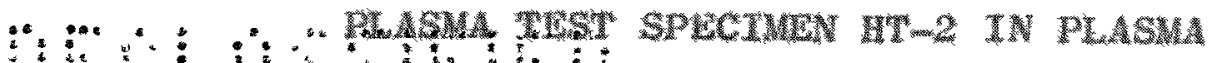

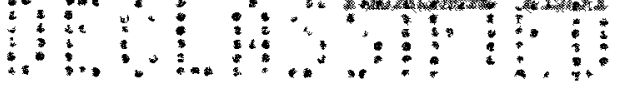




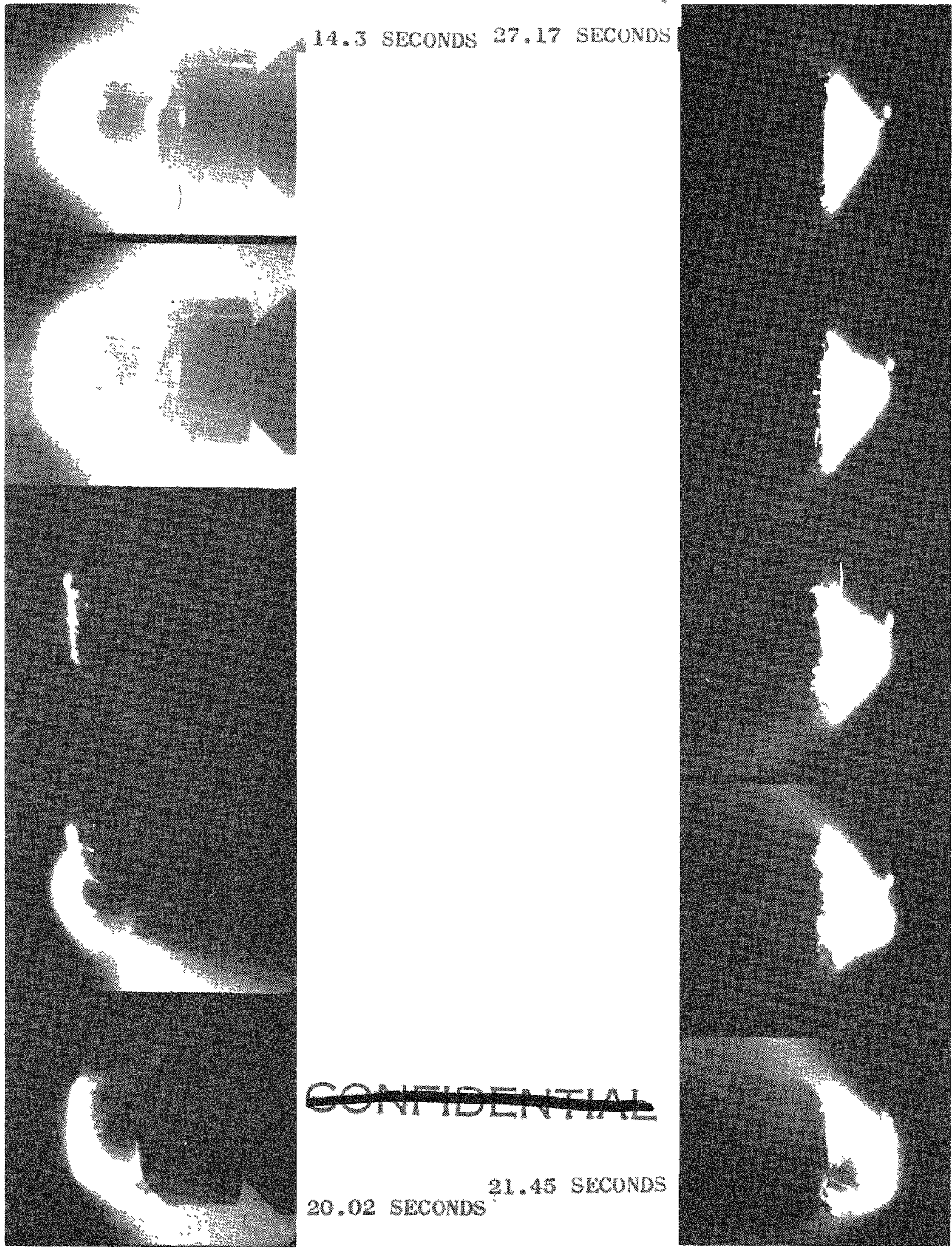

PIGURE 7

PLASMA TEST SPECIMEN WT-2 IN PLASMA 


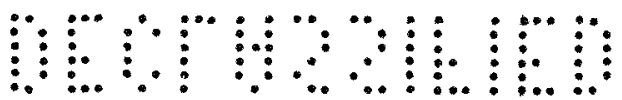

III

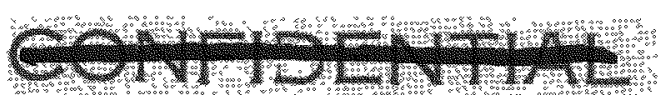

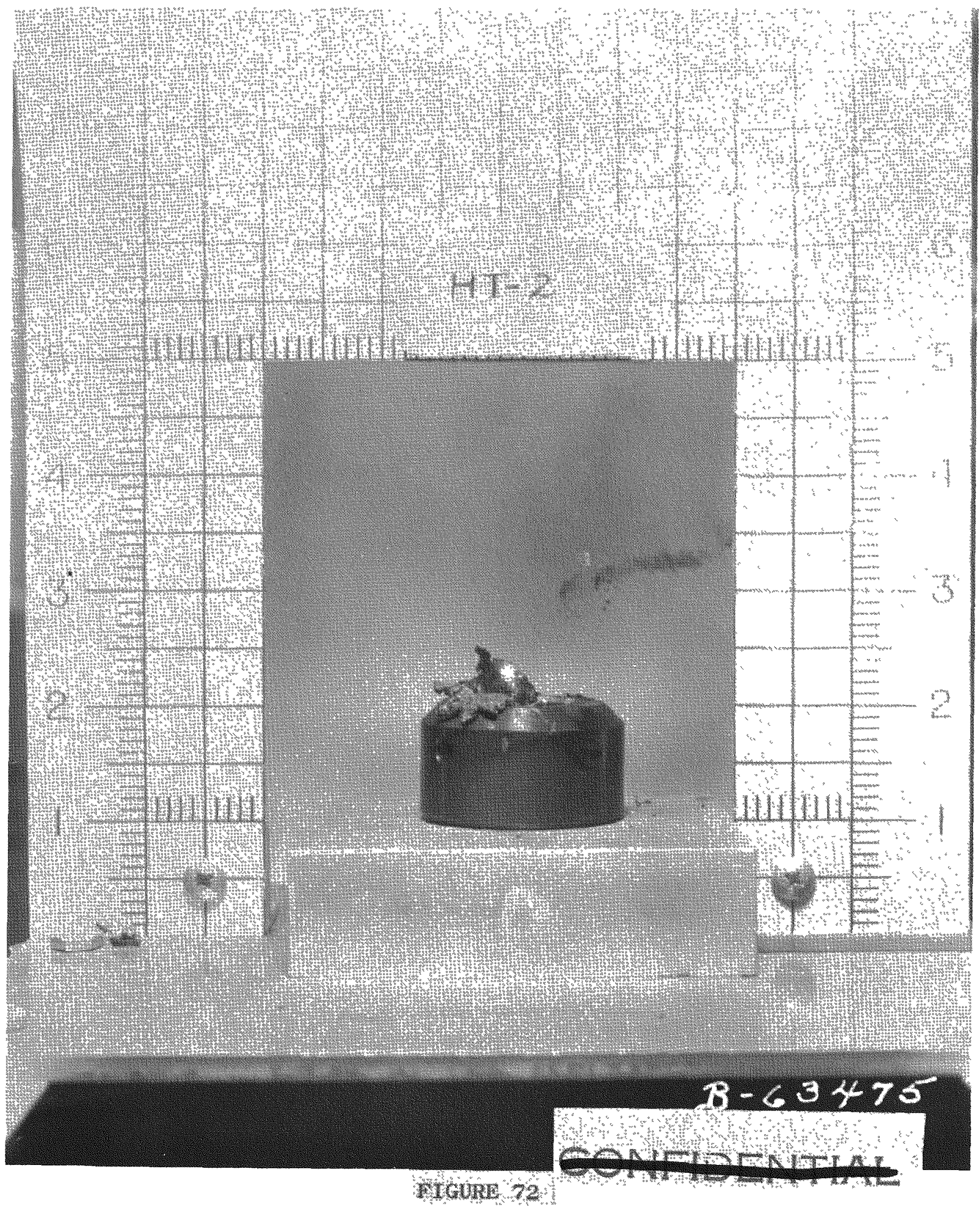

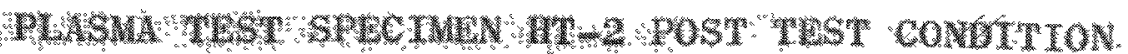

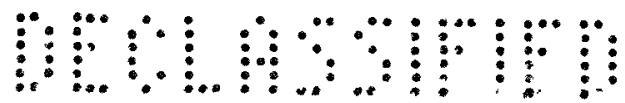



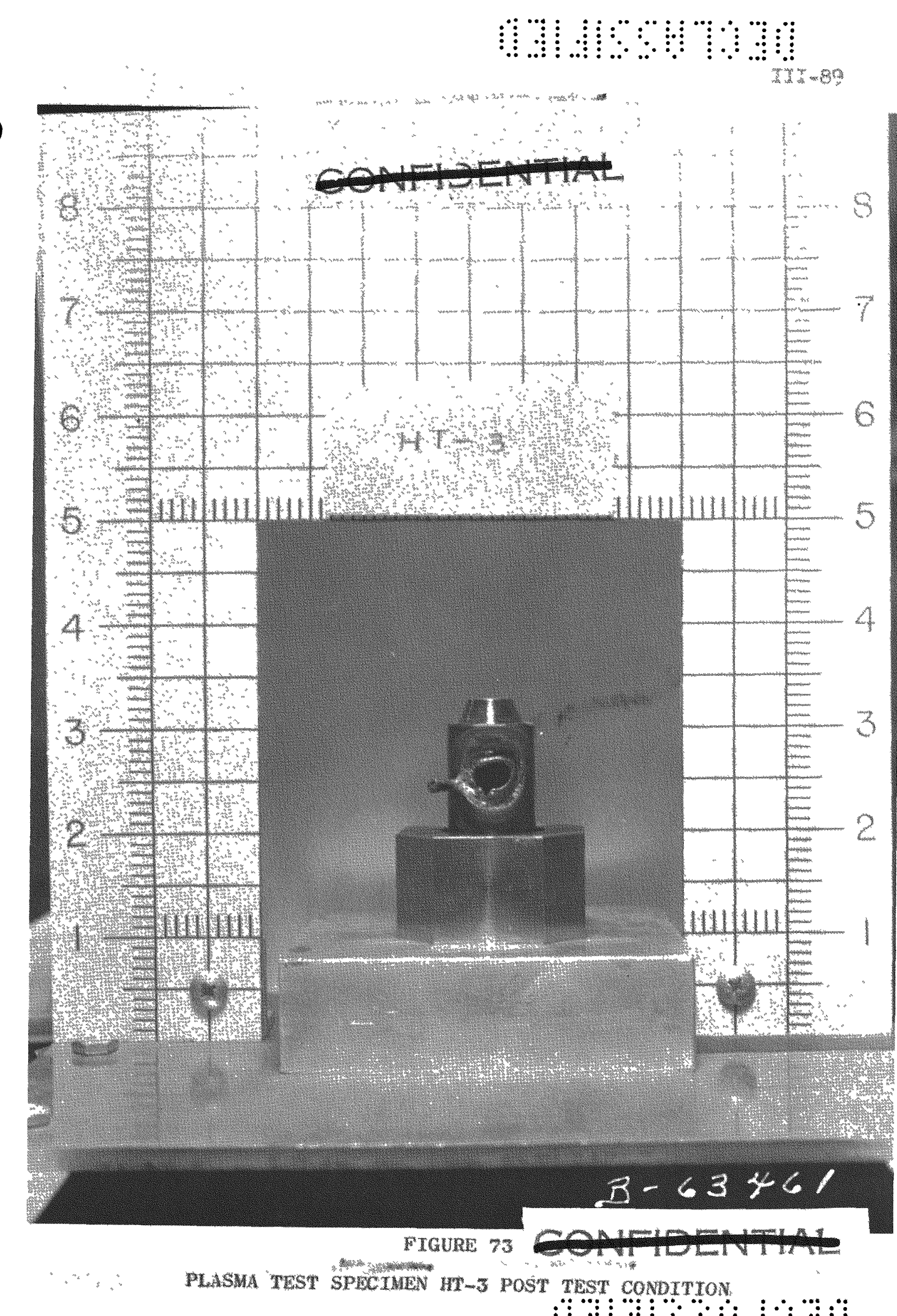

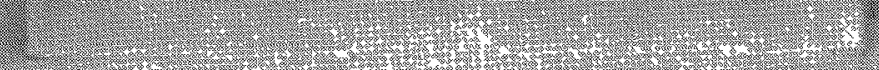

\section{3-63461}

FTGURE 73

3.

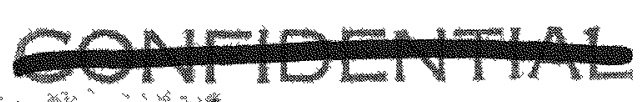

PLASMA TEST SPECTMEN HT-3 POST TEST CONDITION 


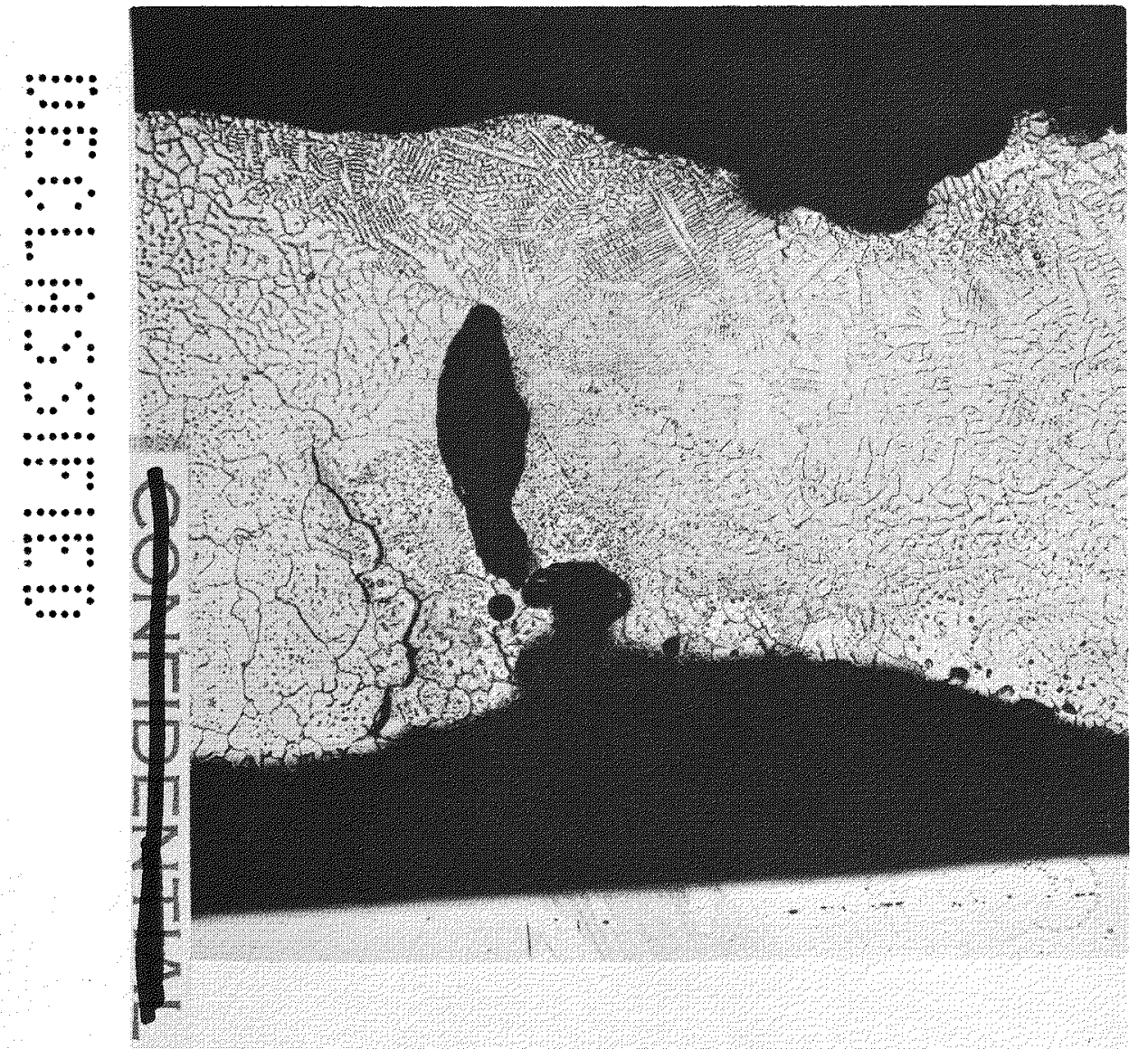

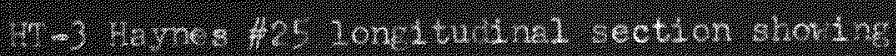
c00 react 1 or threa.

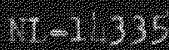

4.2097

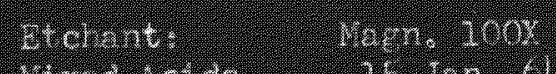
Whed tatede 15- J5e. 61

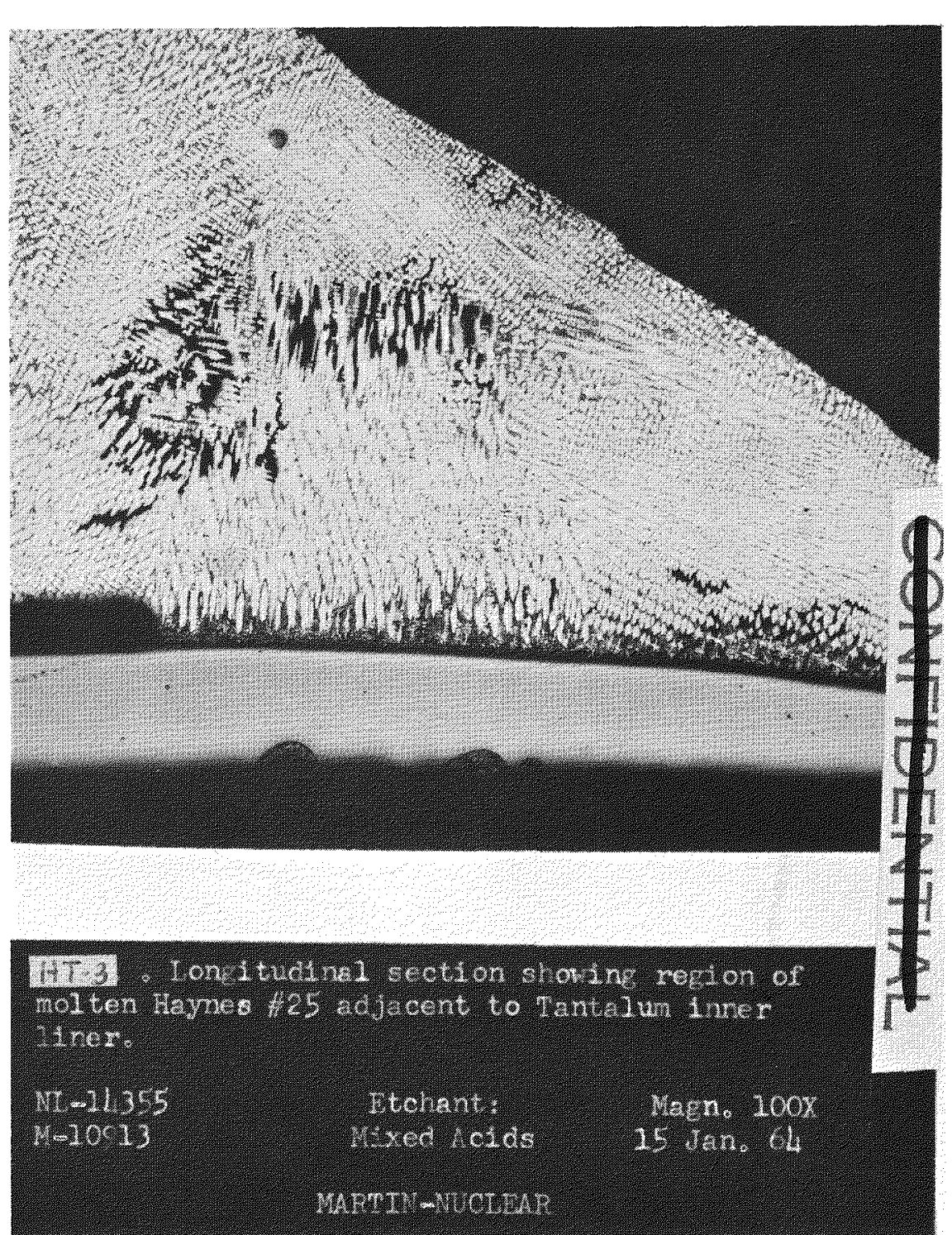

$B$

A

FIGURE 74

PLISMA TEST SPLCIMEN ITT-3 POST TEST CONDIHION

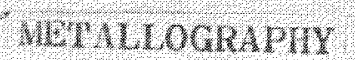




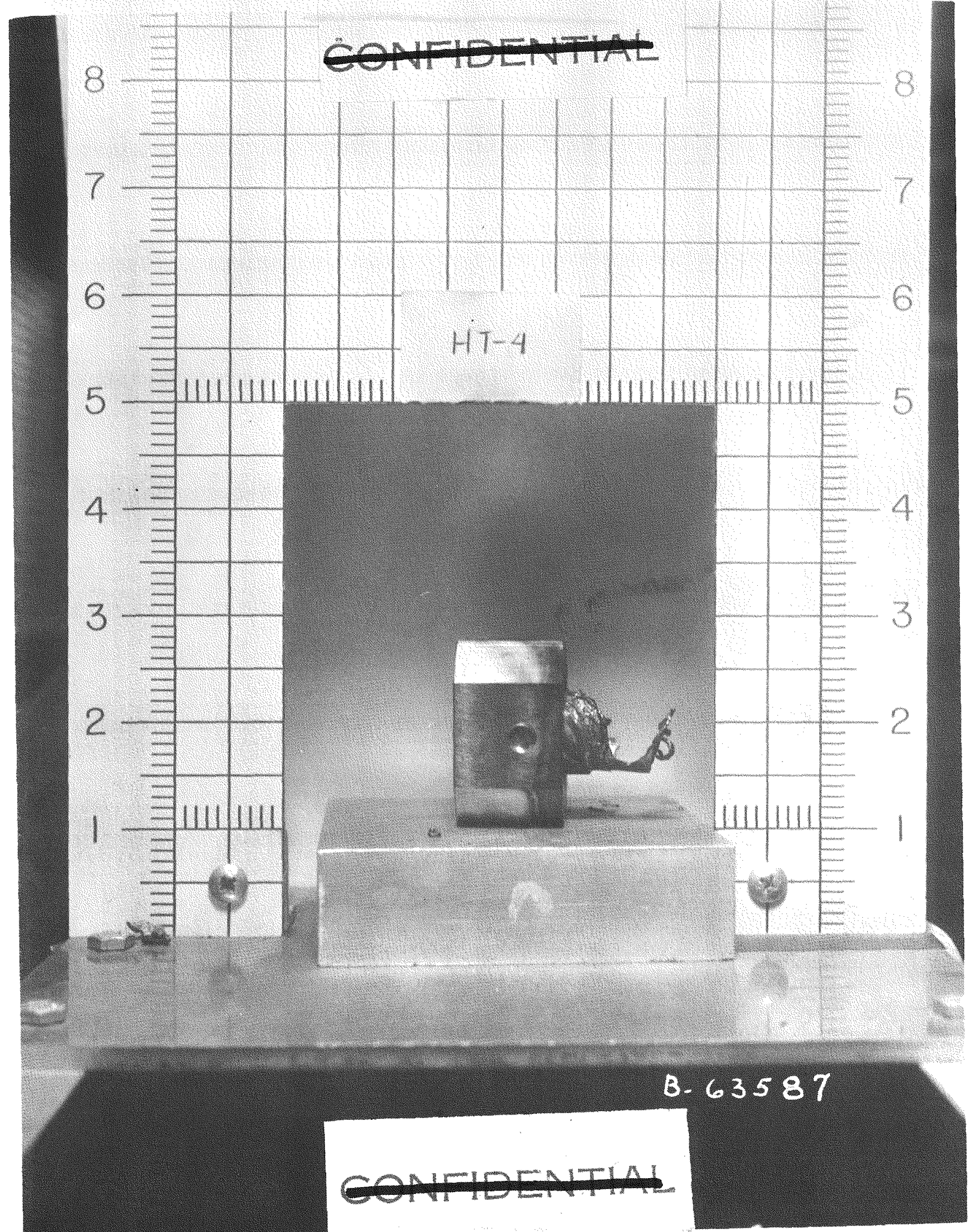

FTCURE 75

PLASMA TEST SPECTMW HT-4 POST TEST CONDITION 


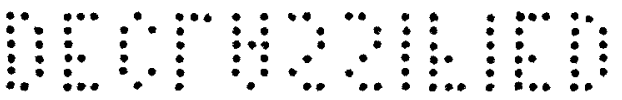

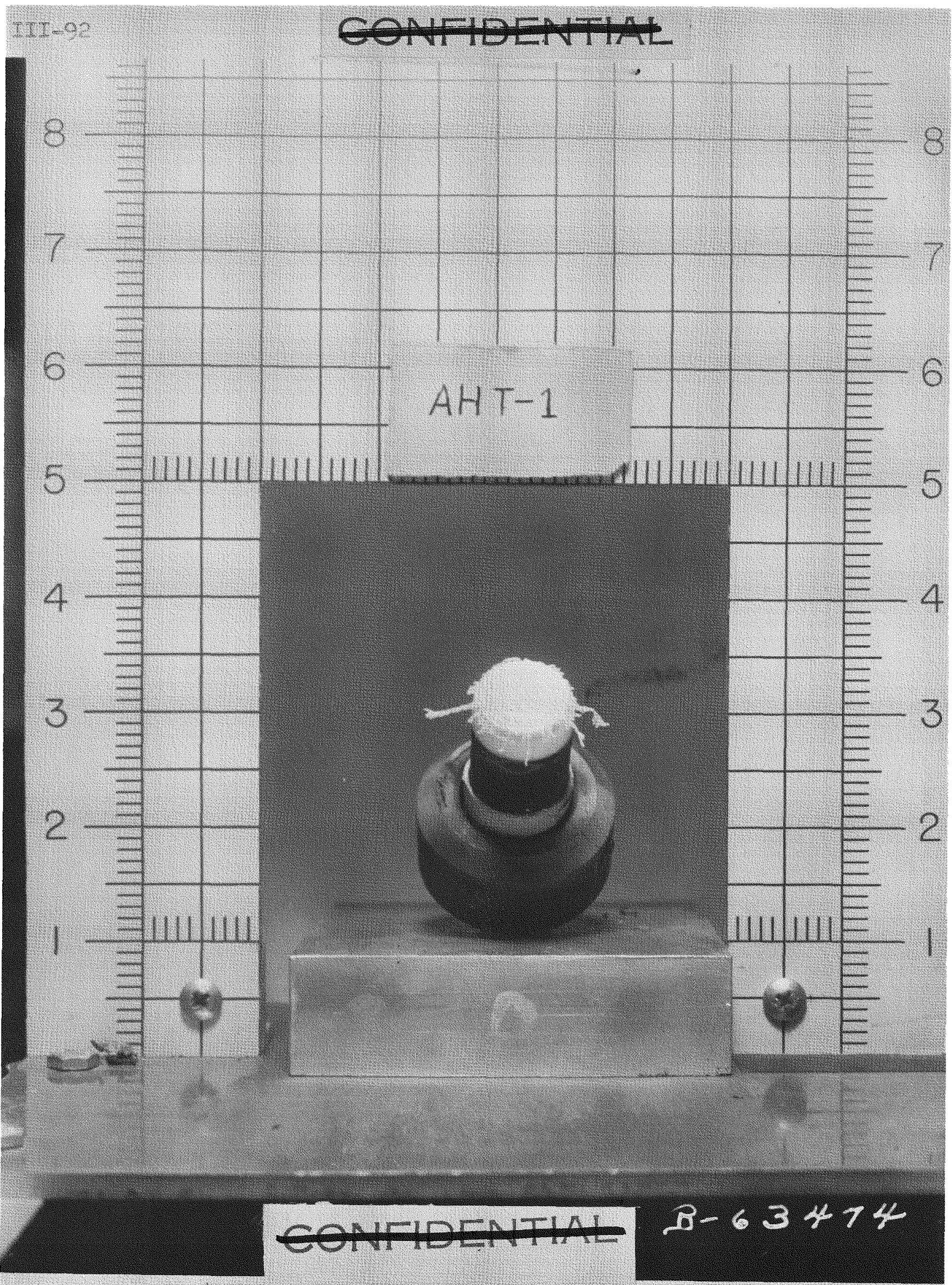

FTGURE 76

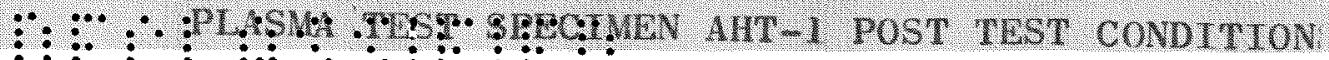

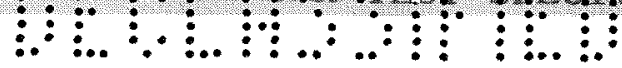




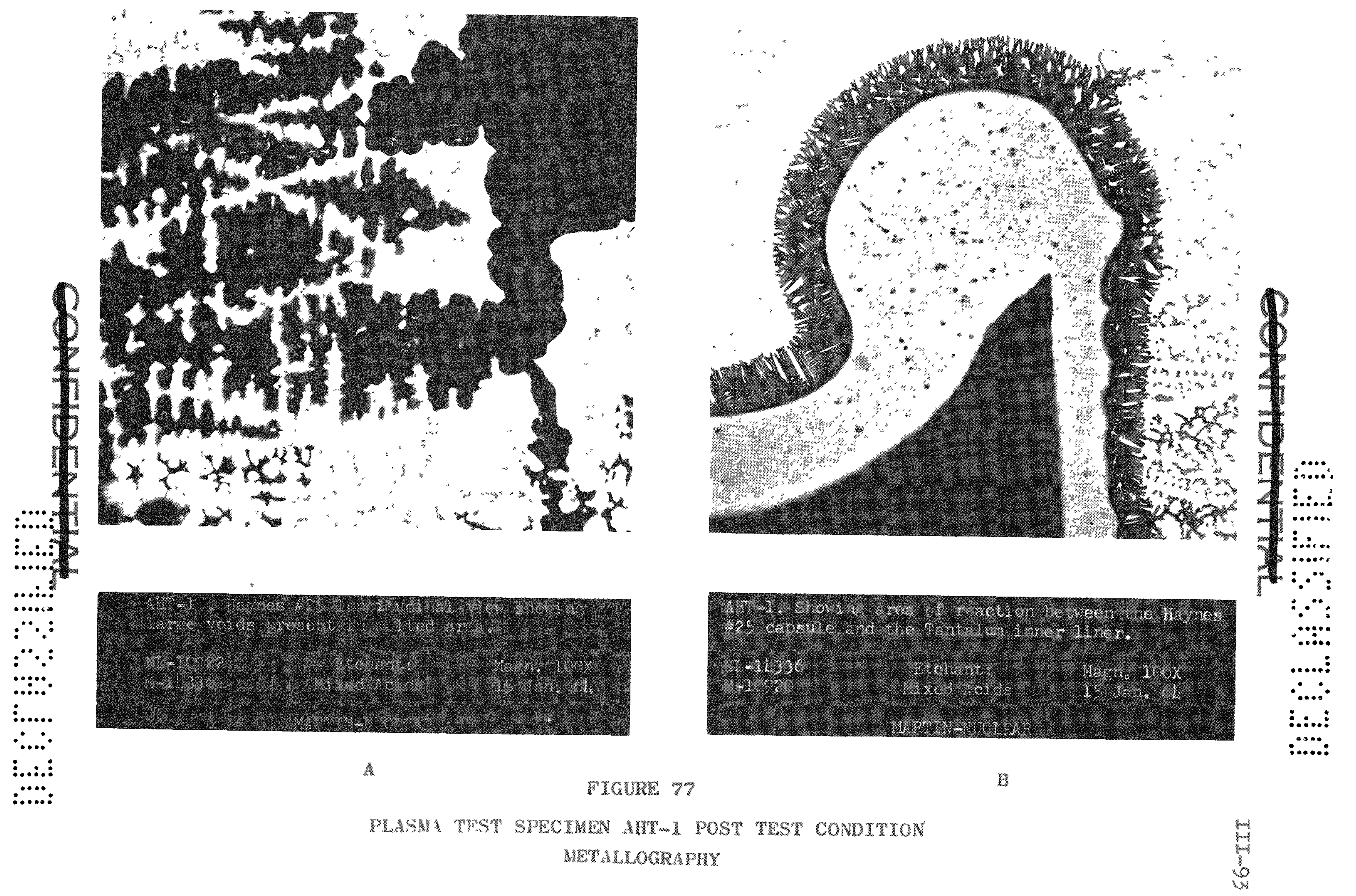




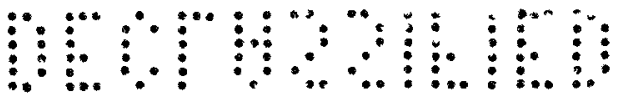

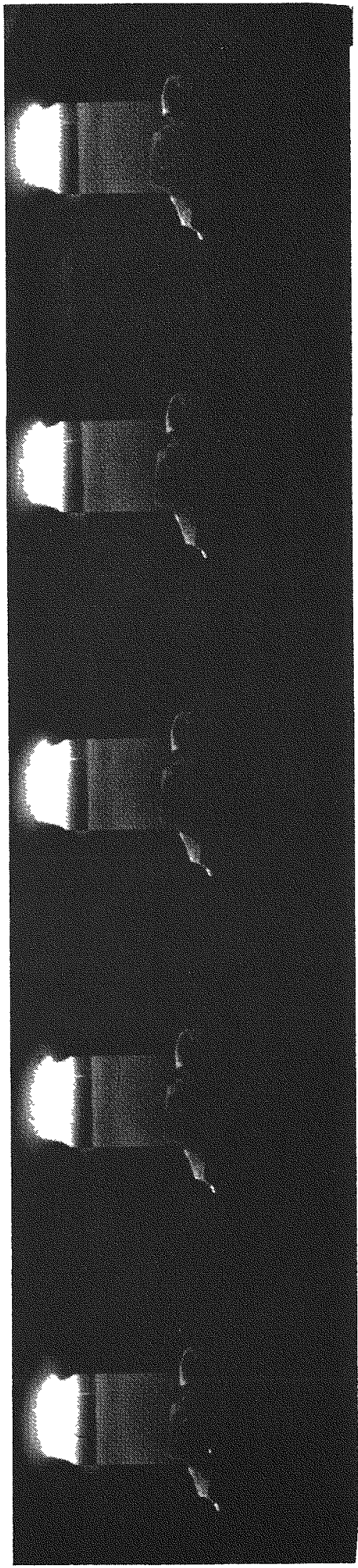

$271.7 \times$ wcomos

279.89 Stconds
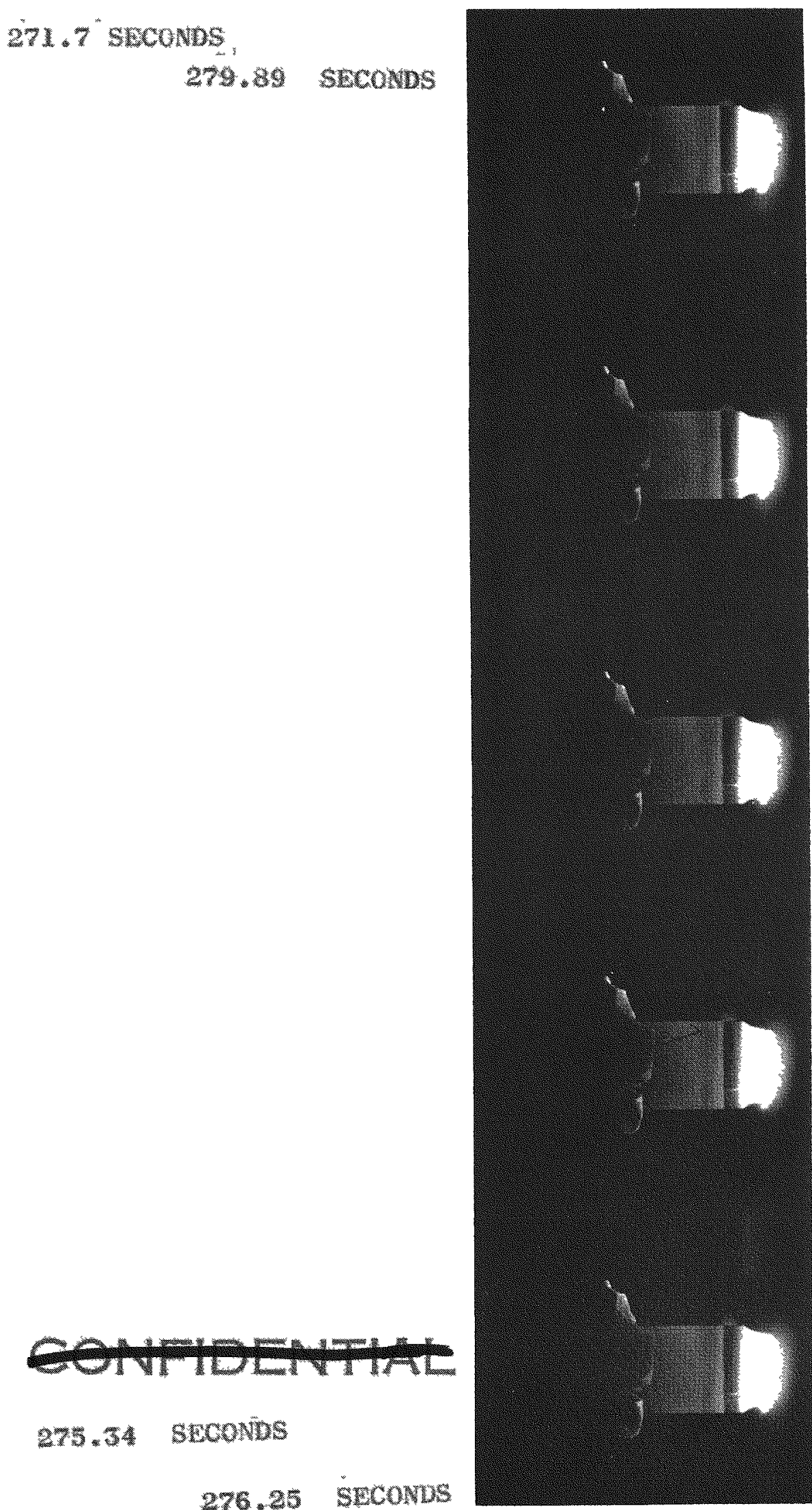

\subsection{SEconns}

\subsection{SECONDS}

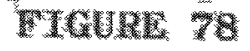

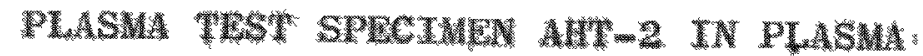




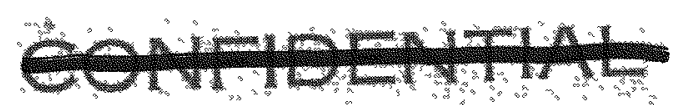

280.8 scontrs

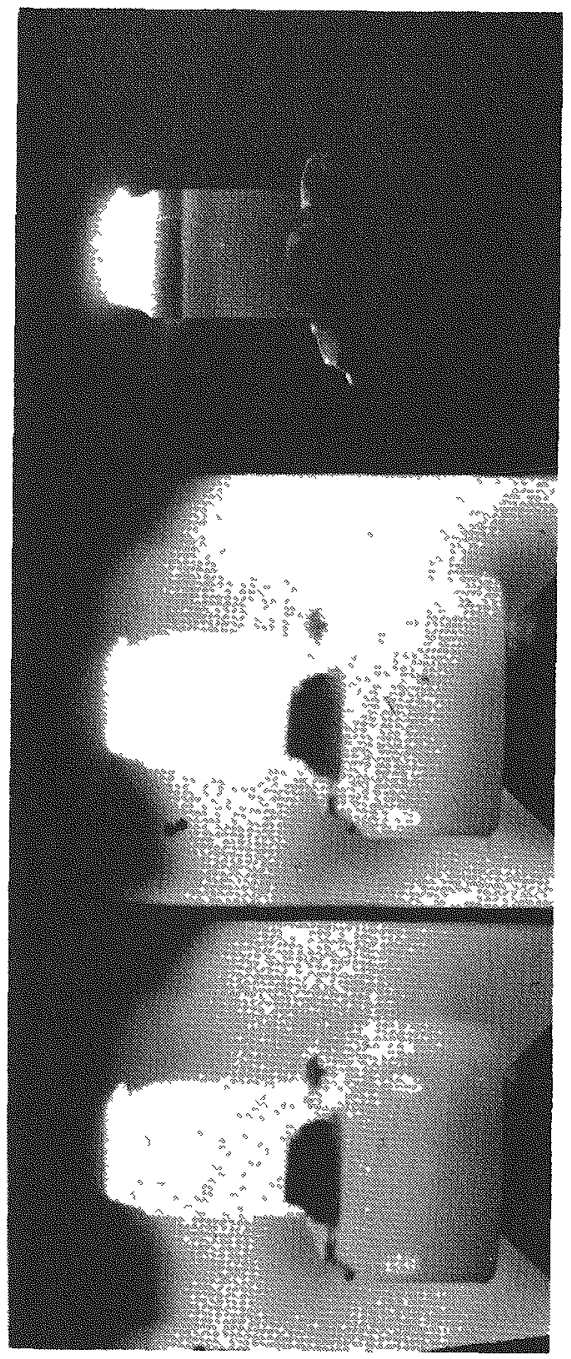

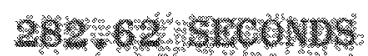

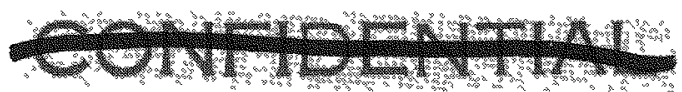

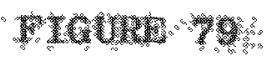

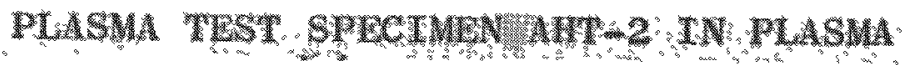




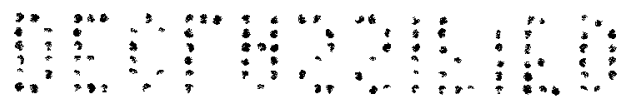

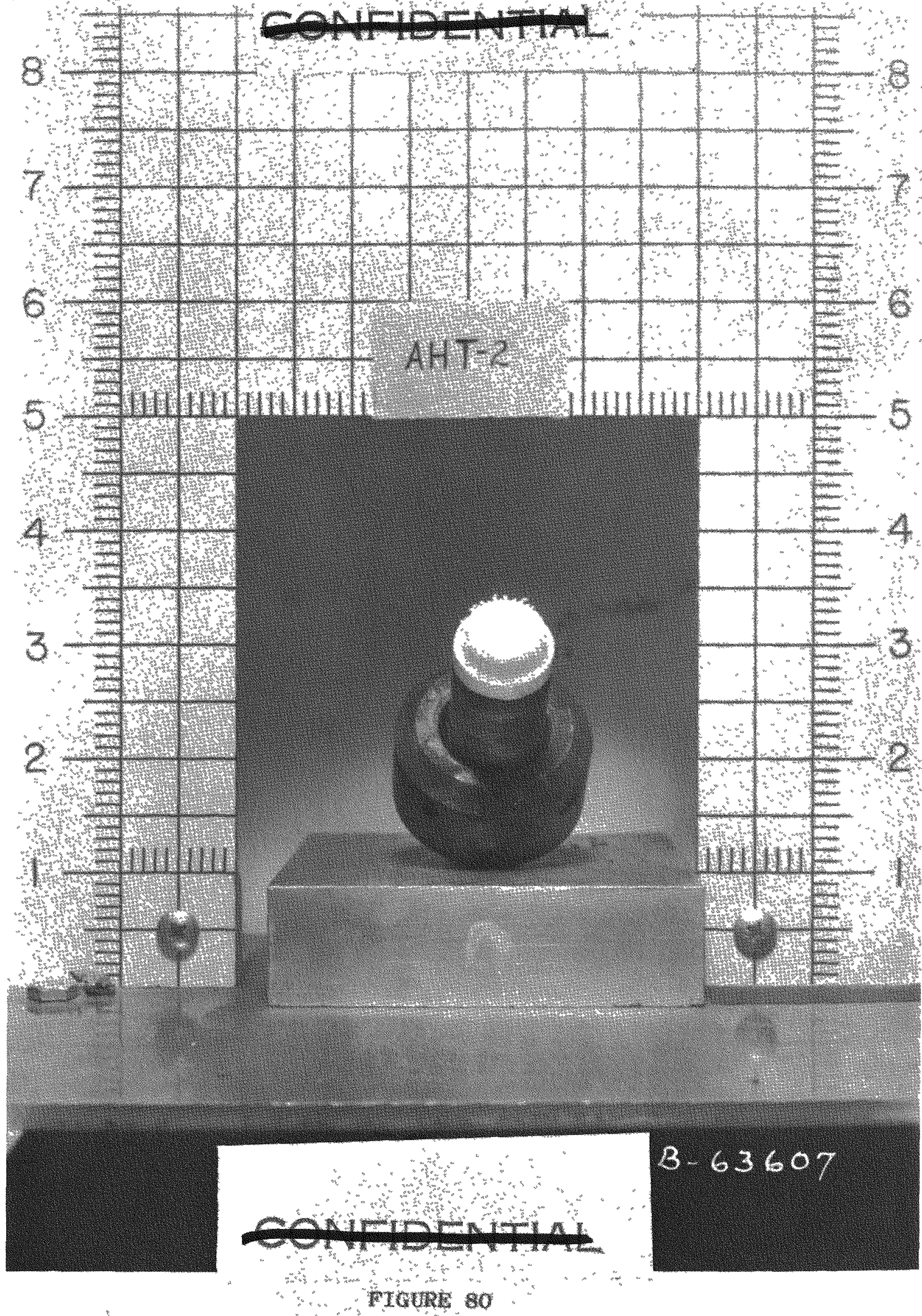

PLASMA TEST SPECTMIN ARPT-2 POST TEST CONDTTTON

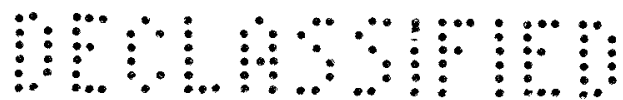



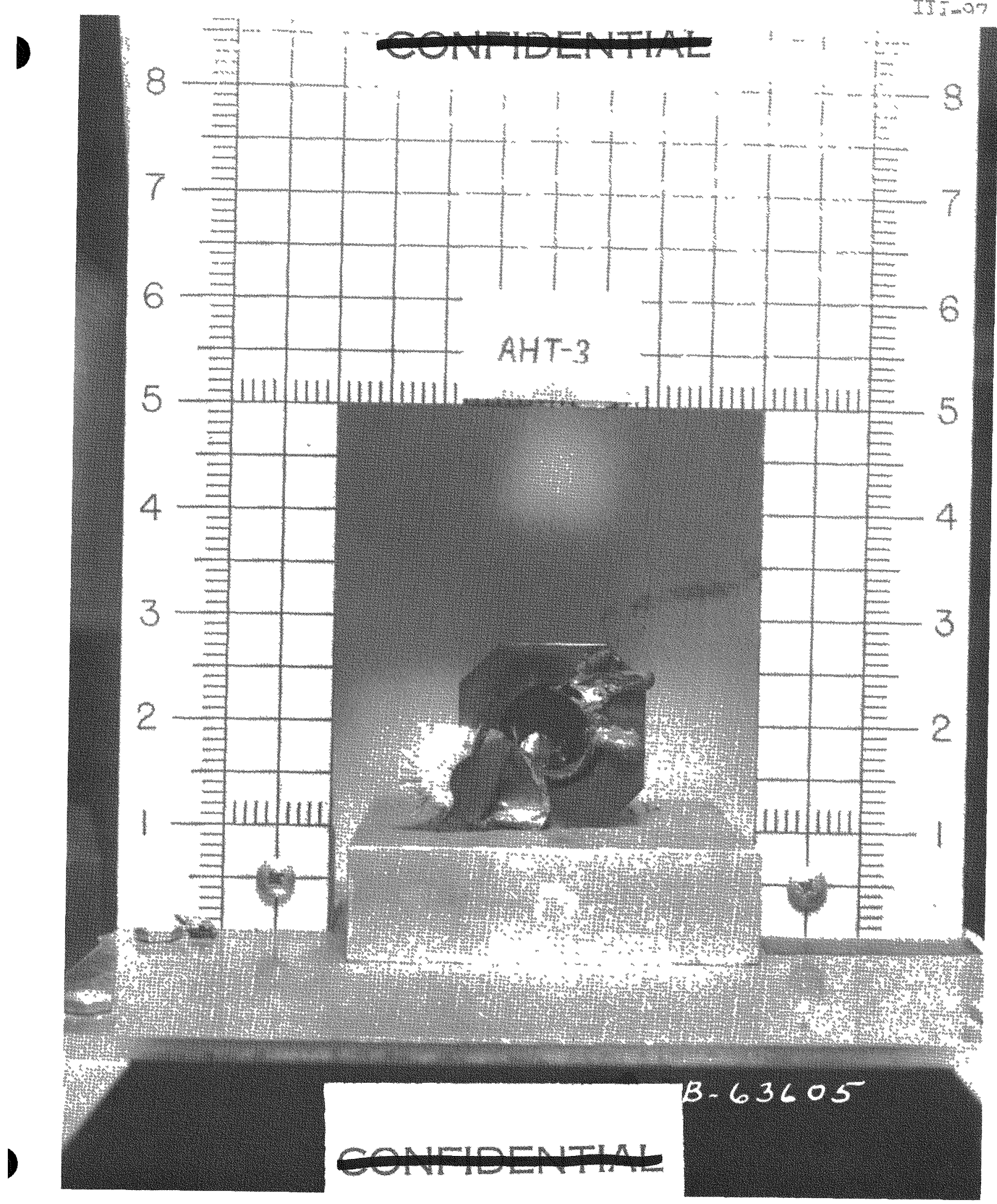

Frauk 81

PLASMA TEST SPECIMEN ALT -3 POST TEST CONDITTON

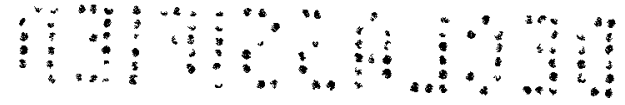




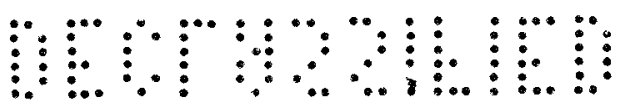

mat.

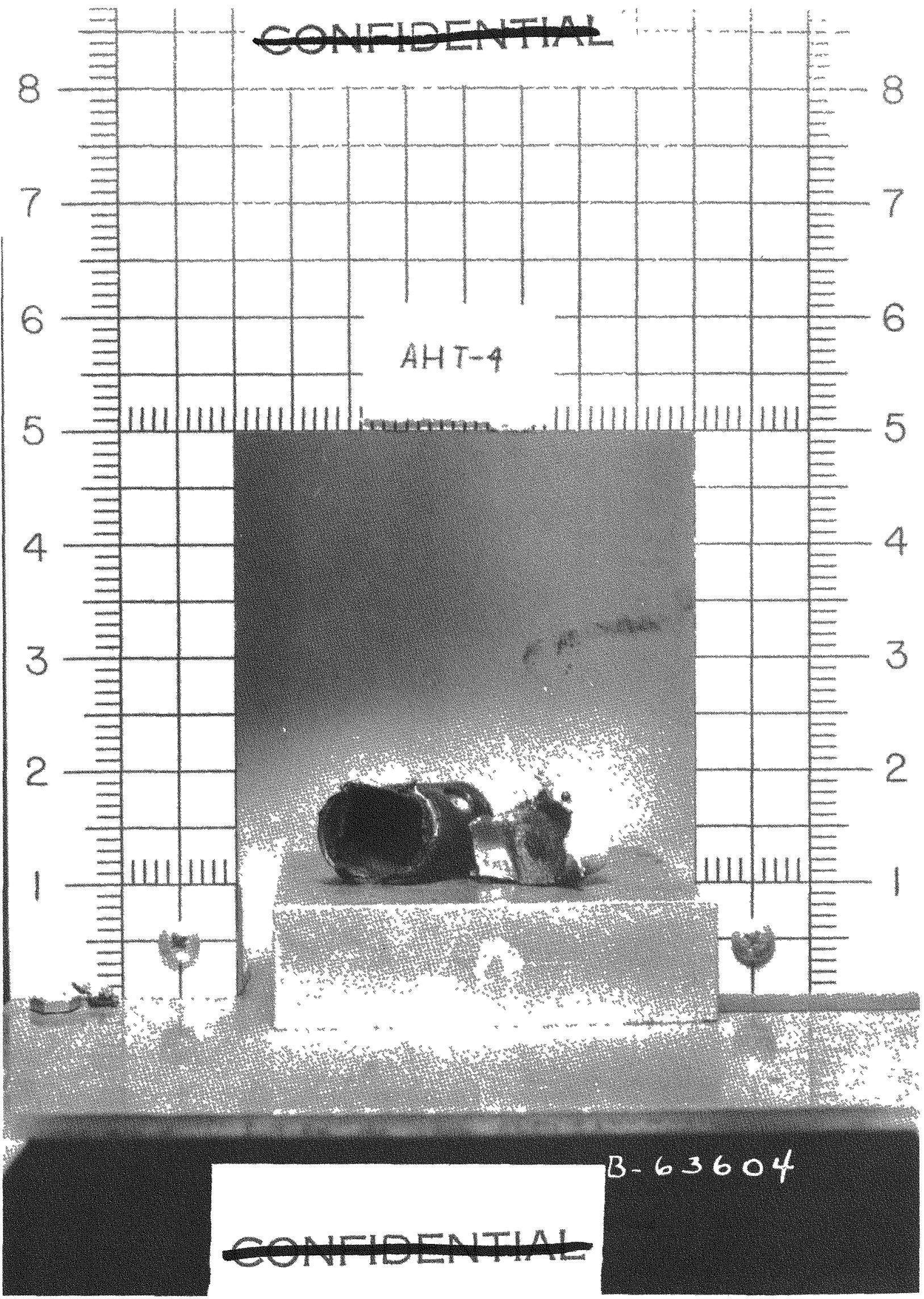

FTGURE 82

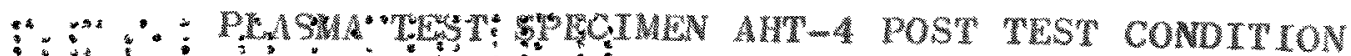

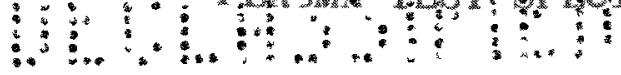




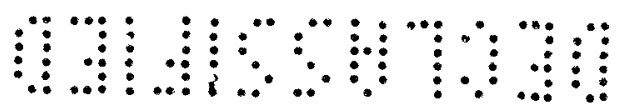 \\ Int 90}

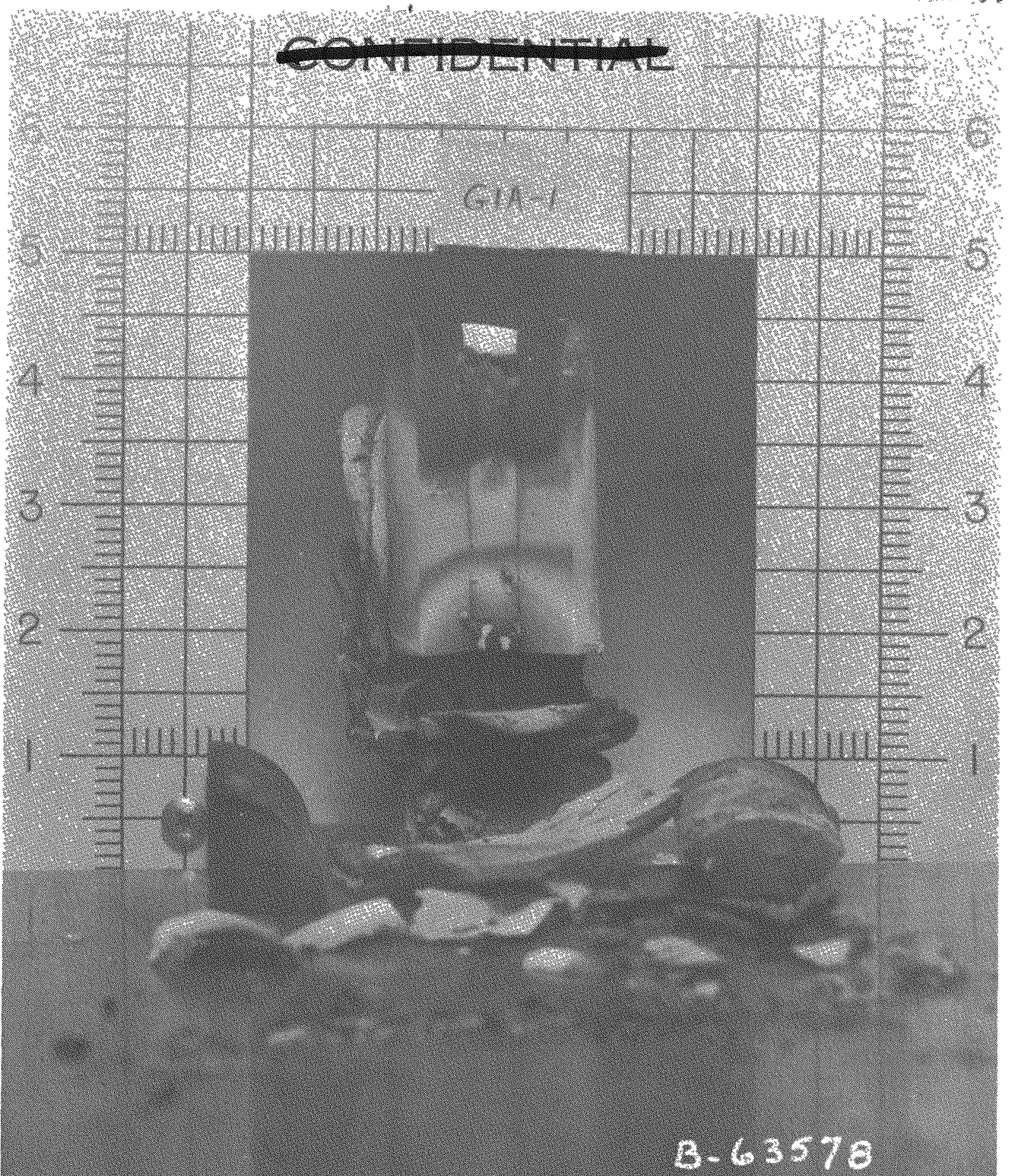

$3-63=8$ 


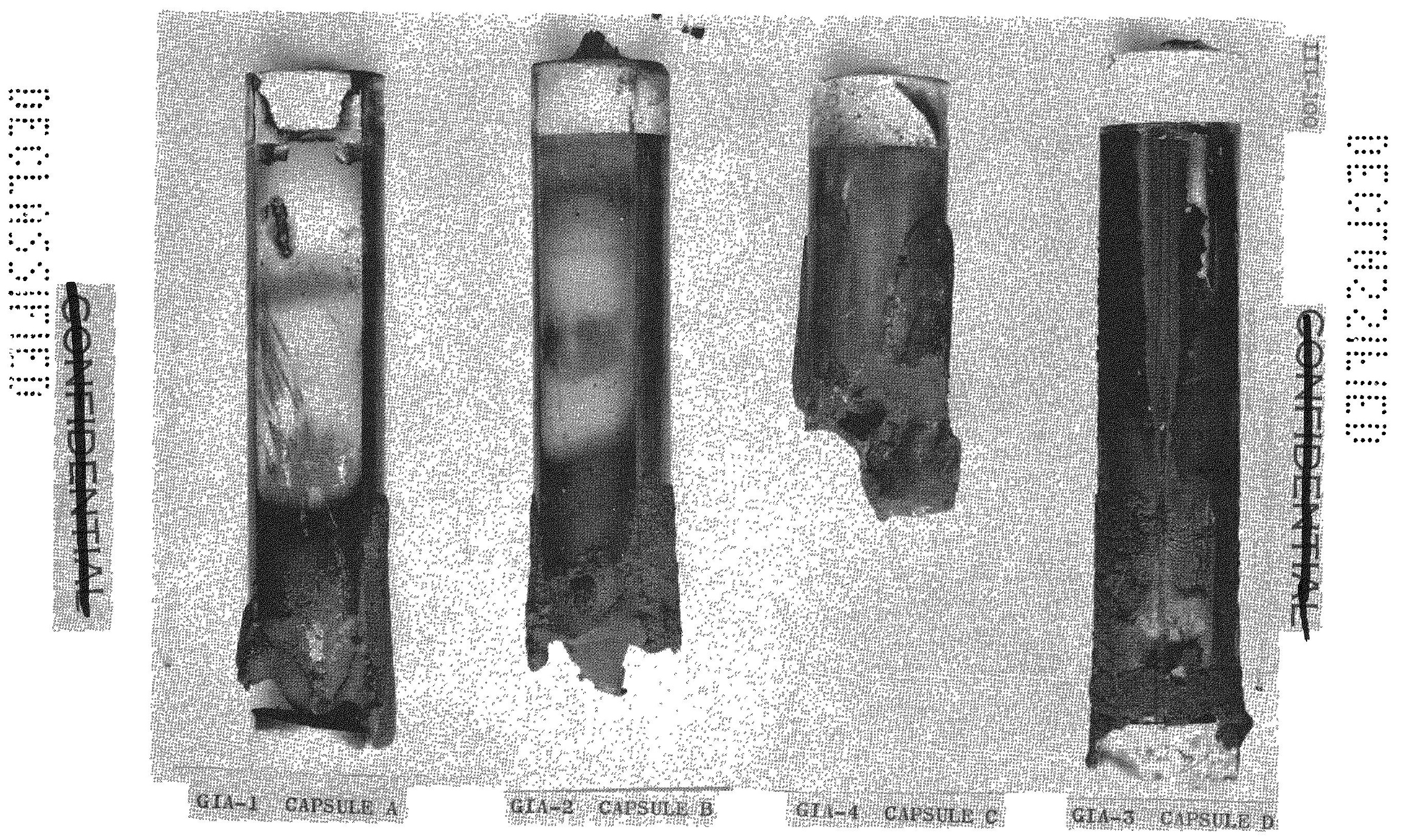

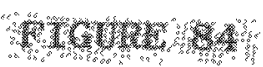

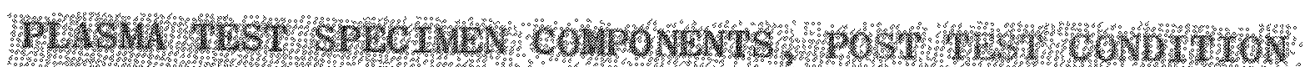




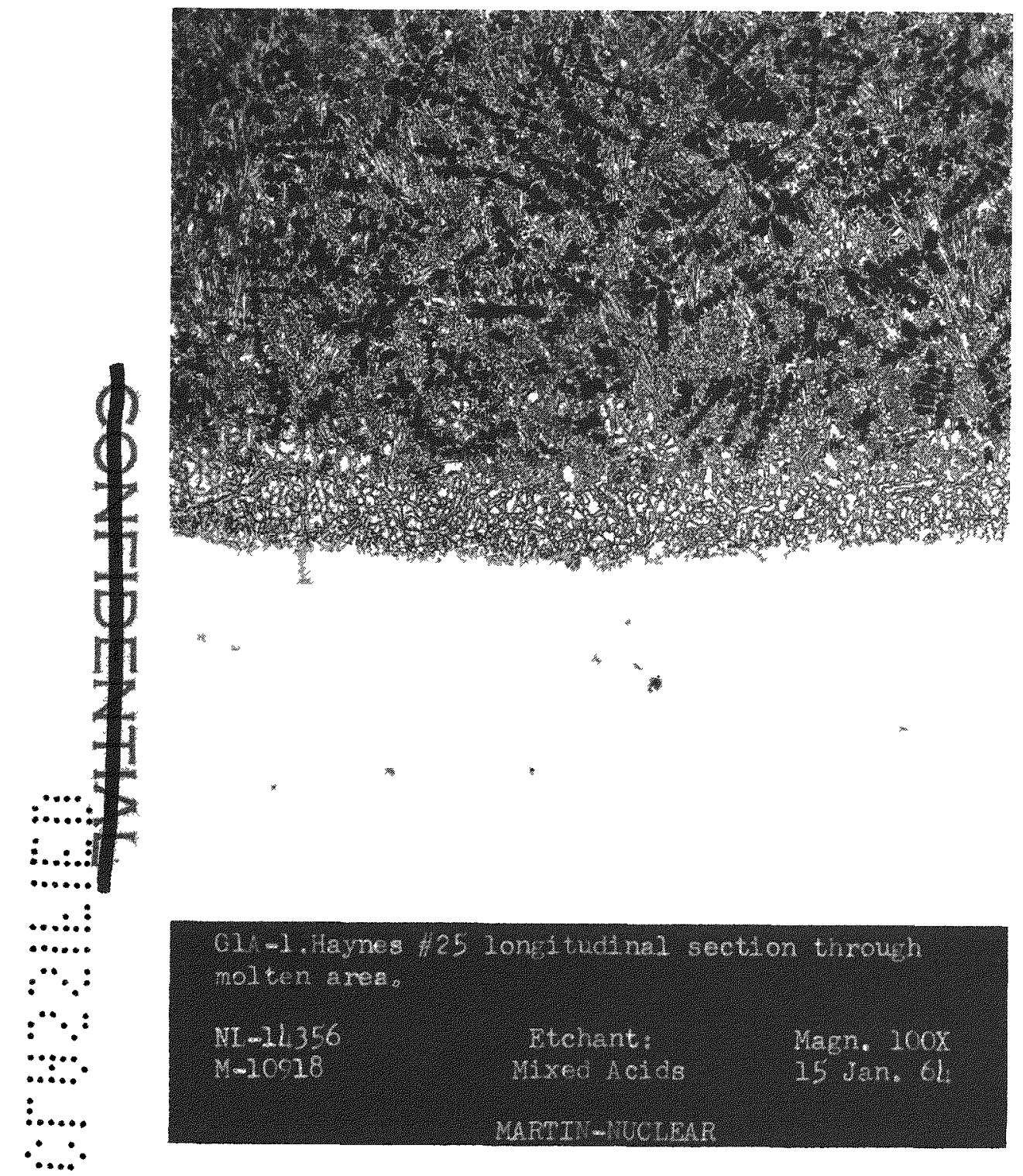

A

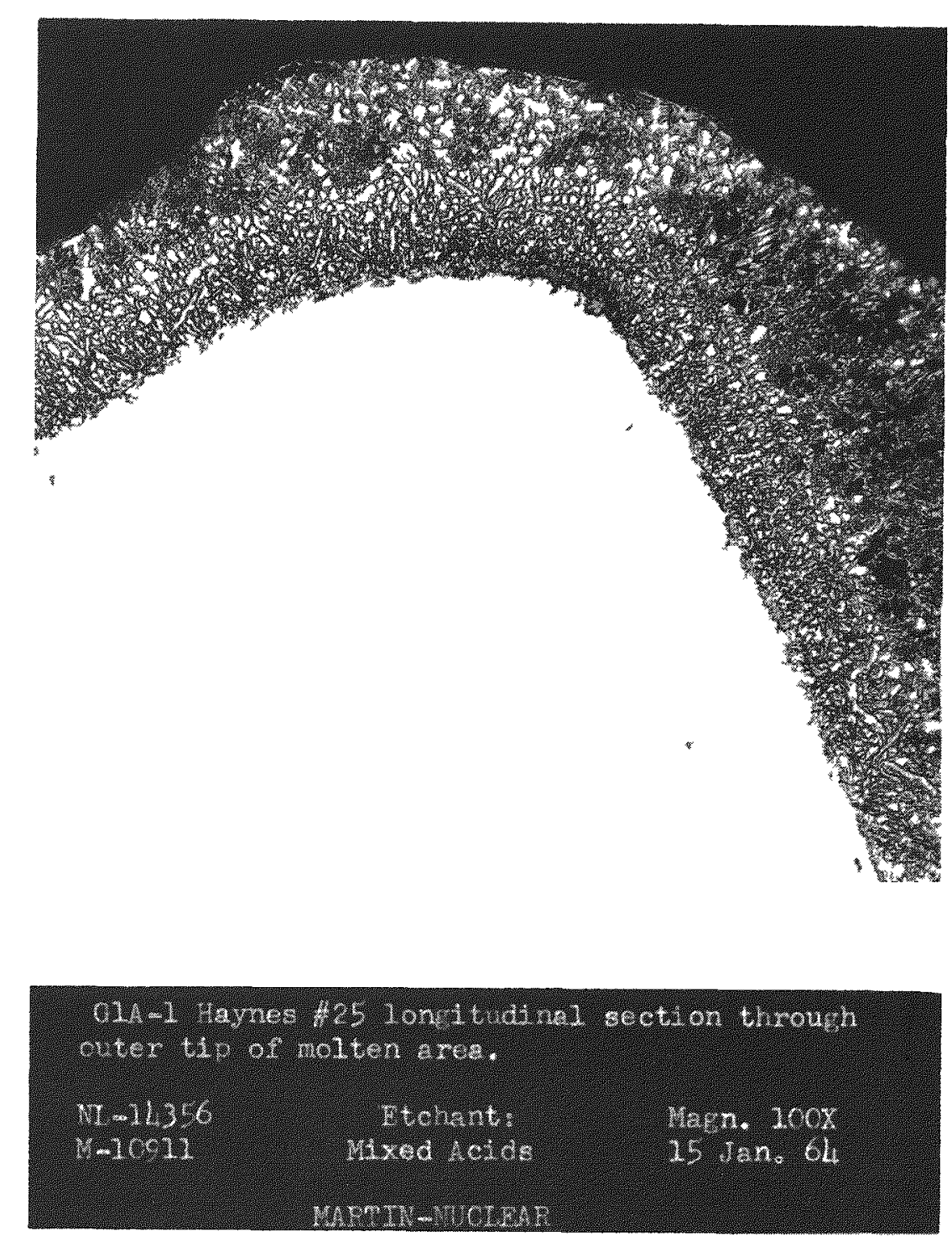

B

\section{PTGUEE 85}

$+$

$\because \because$

$\because \cdots$

$\because \cdots$

.....:

$\therefore .$.

¿....:

$\therefore \cdots$ :

PLASUA TEST SPECTMLN GIA-1 POST TEST CUNOTTION 


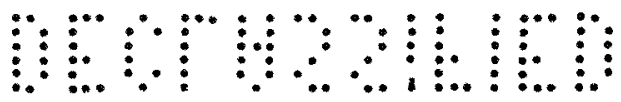

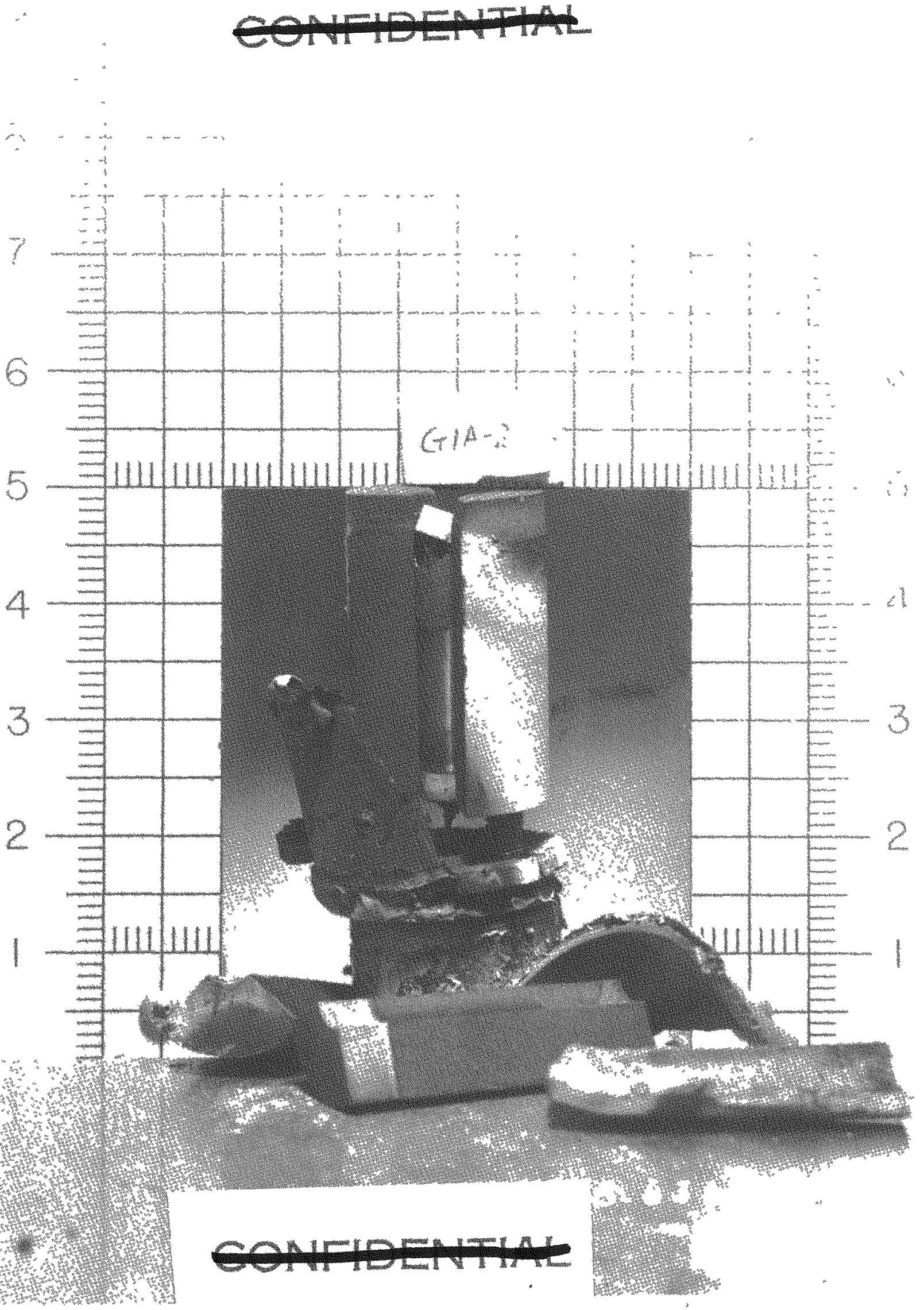

PTCURE 86

PLASMA TEST SPECIMEN GIA-2 POST TEST CONDITION 


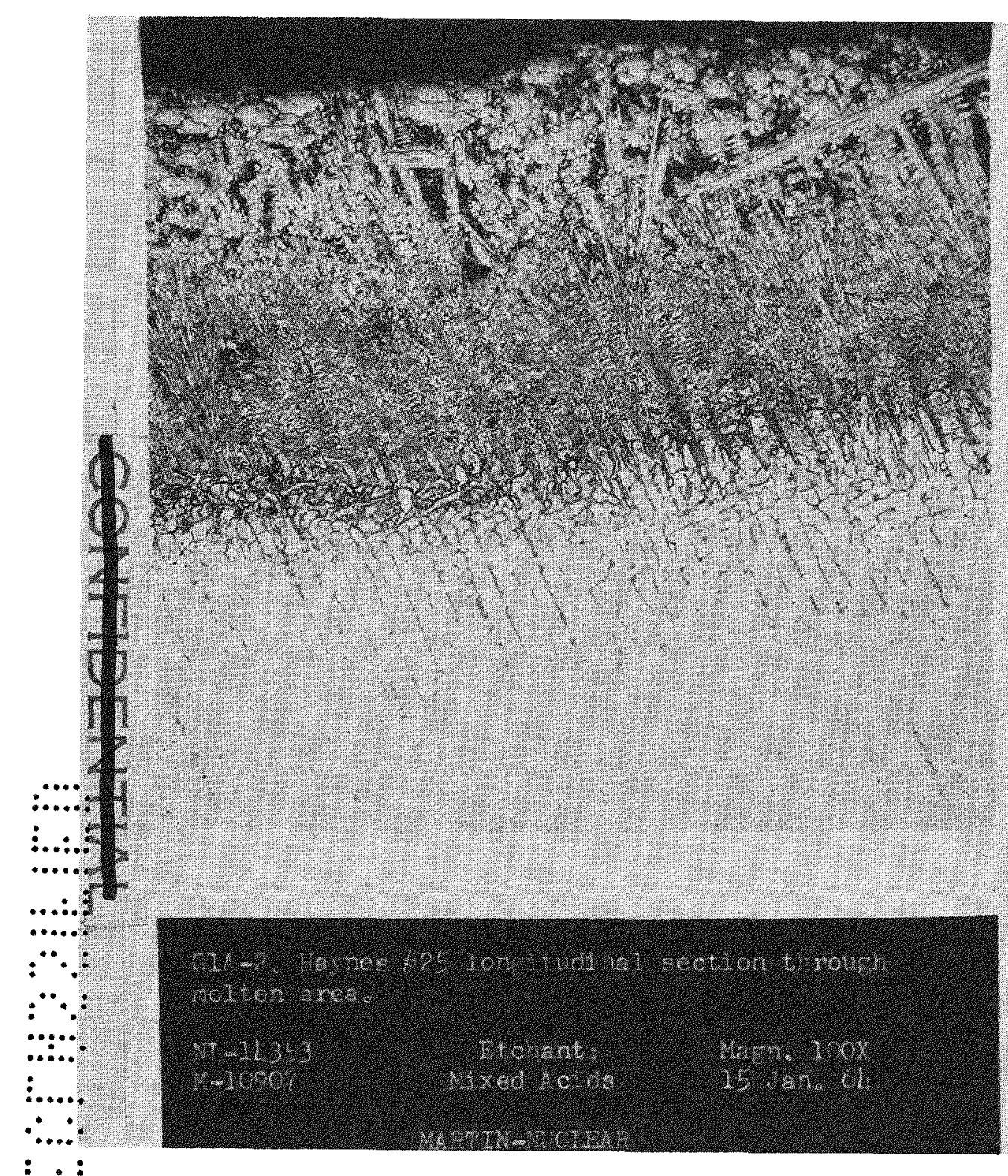

$\vdots \ldots . .8$ $\therefore . . .:$

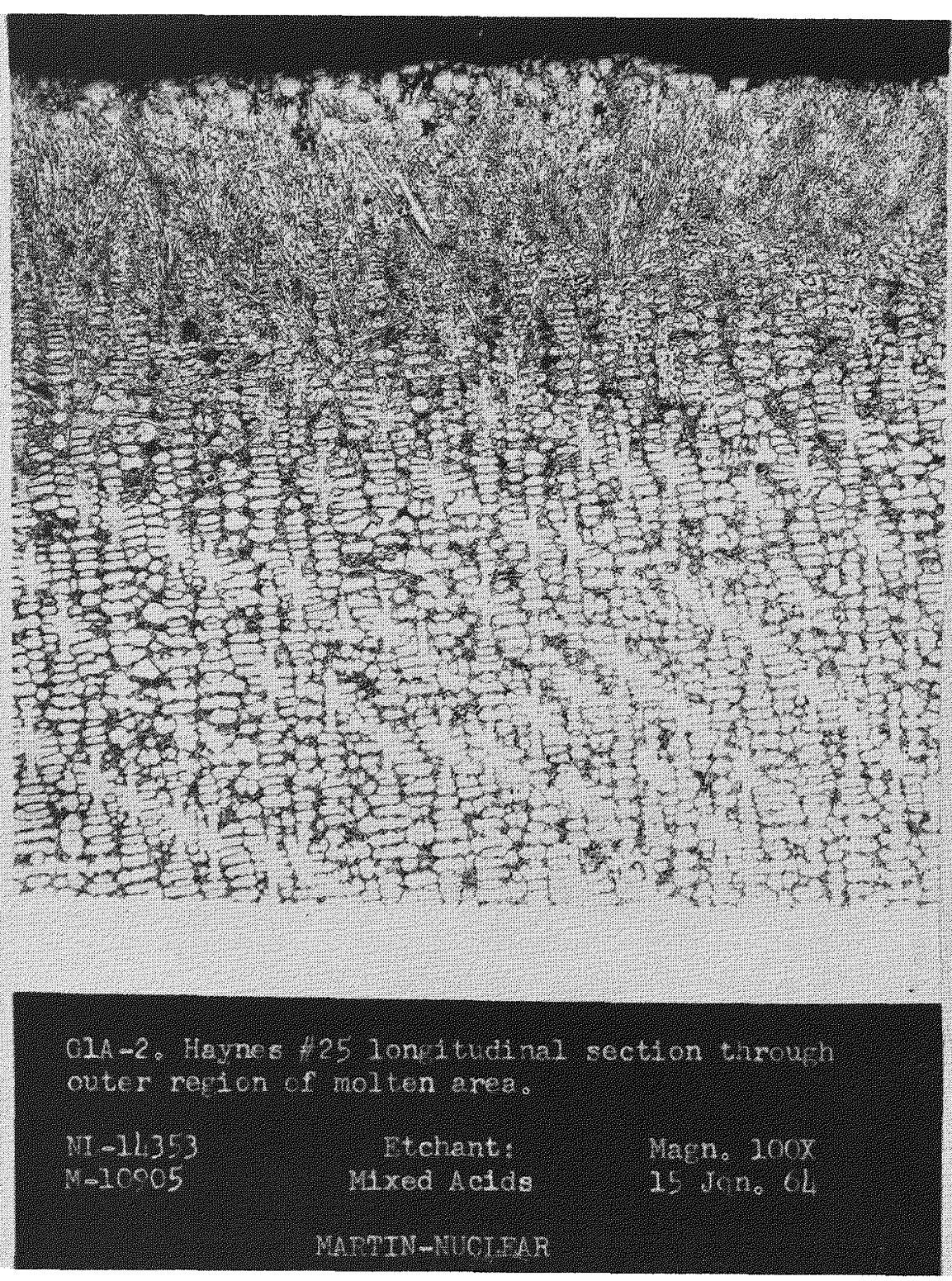

3.

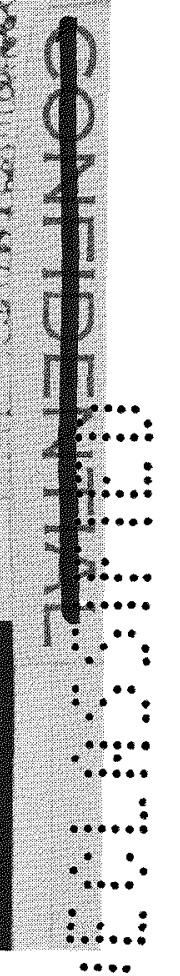

FICUR: 87

PLASH TLST SPECTMEN GIA-2 POST TEST CONDTRION Werariogratin 


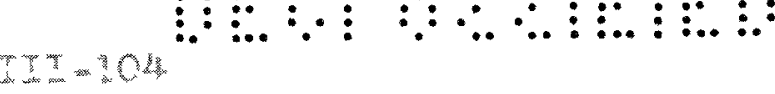

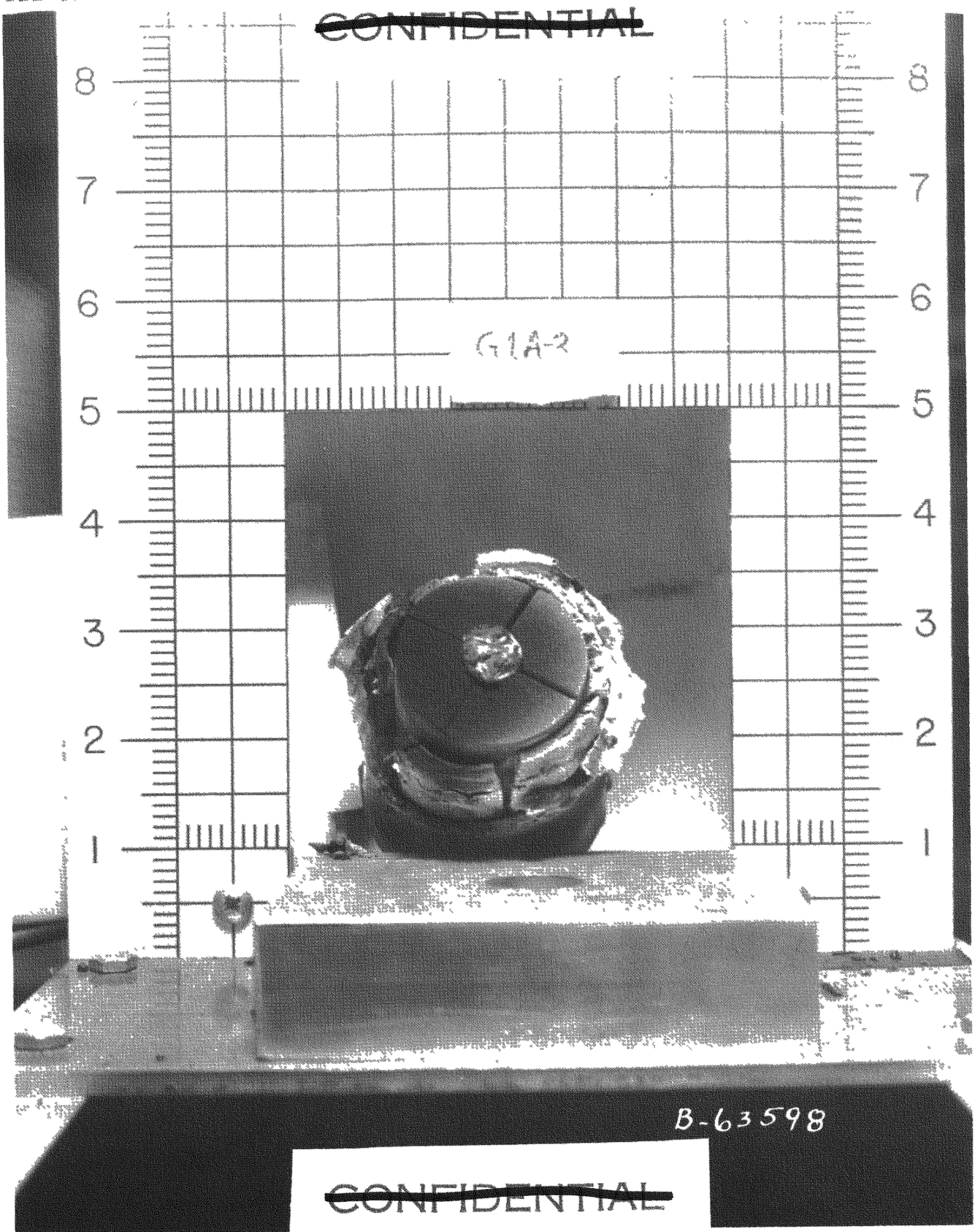

FĬGURE 88

PLASMA TEST SPECIMEN GIA-3 POS䇣 TEST CUN 
si

Dis

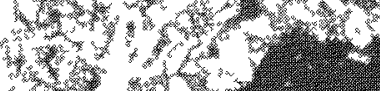

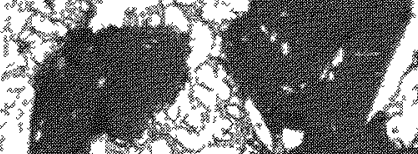

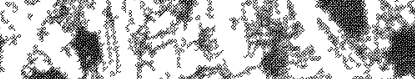
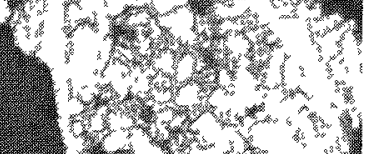

inis.

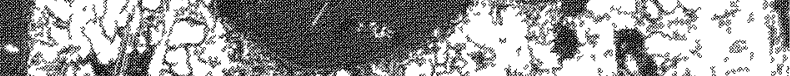

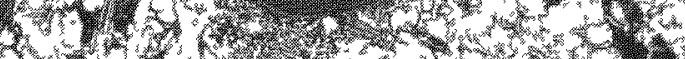

When
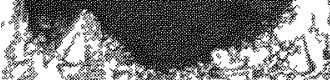

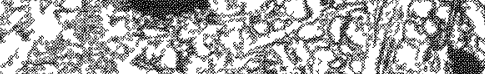

(6)

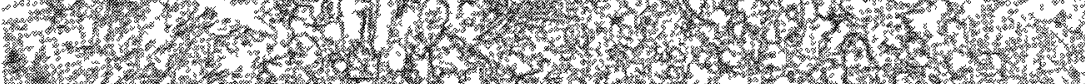

H.

r.m.
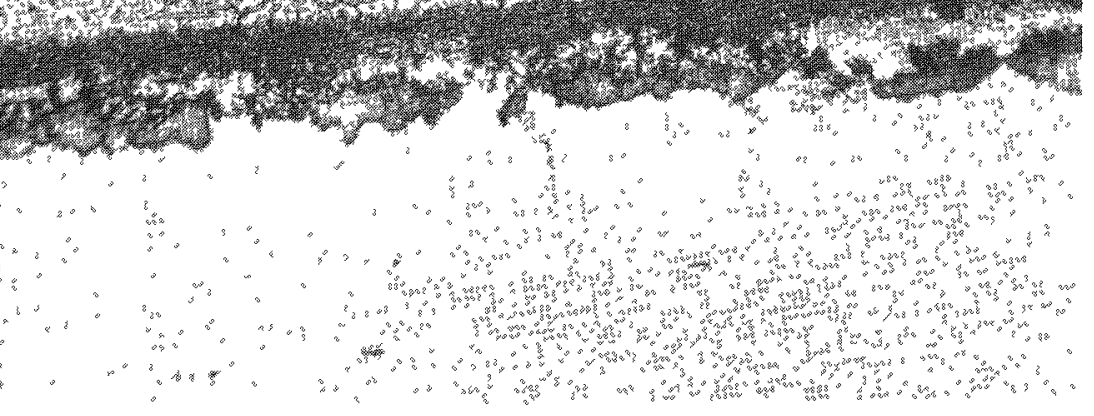

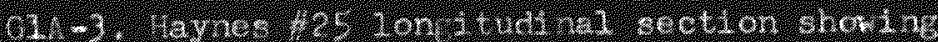

oxted z nolustons in the nol ten arca.

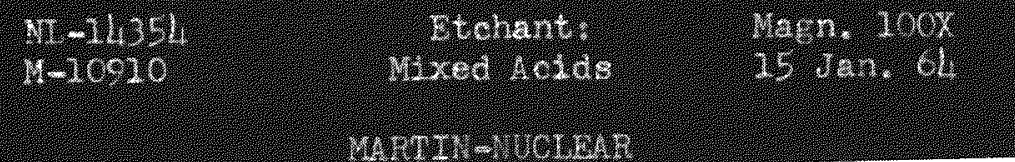

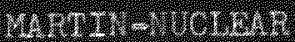

4

FIGURE 89

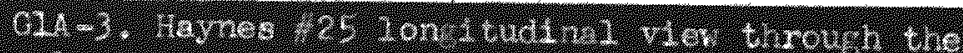
nal tar arca shovent oxtale inclustion.

Nit -11354

Btchant?

4-10608

Wiked idst

Yagn. $100 \%$

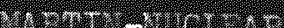

B.

PLASMA TEST SPECIMEN GIA-3 POST TEST CONDITTONS

METALLOCRIMU

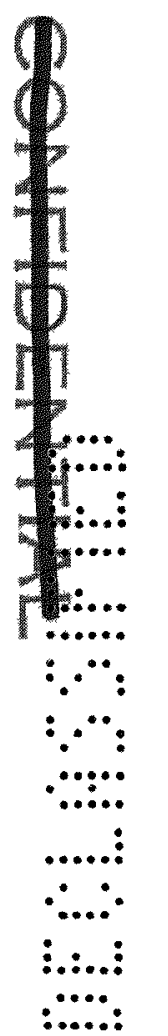




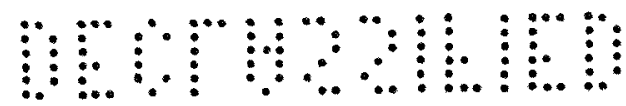

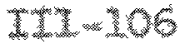

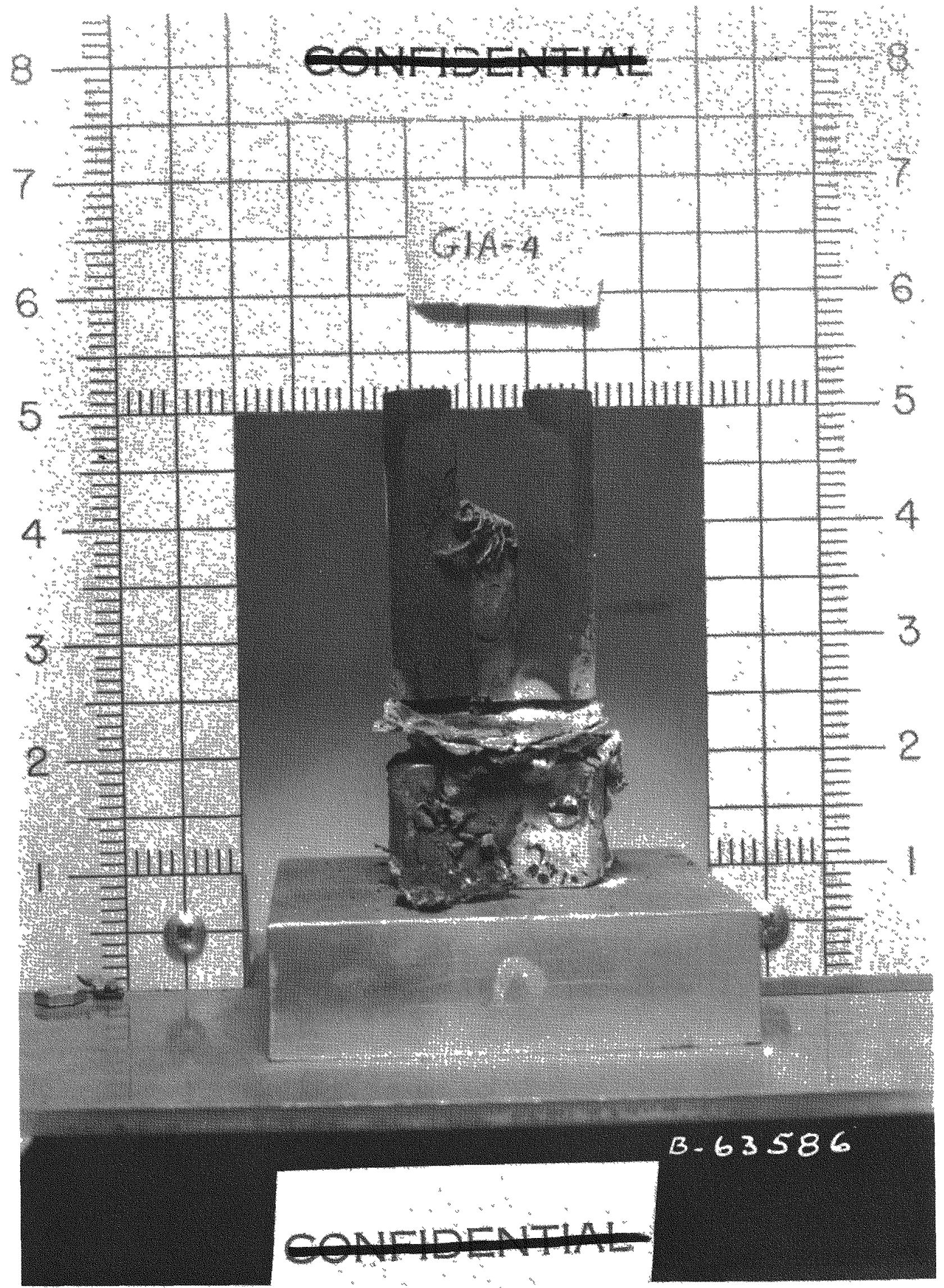

ICURE 90

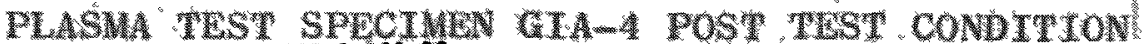

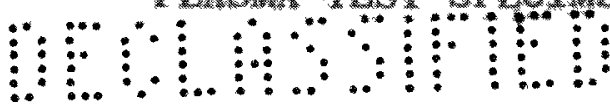




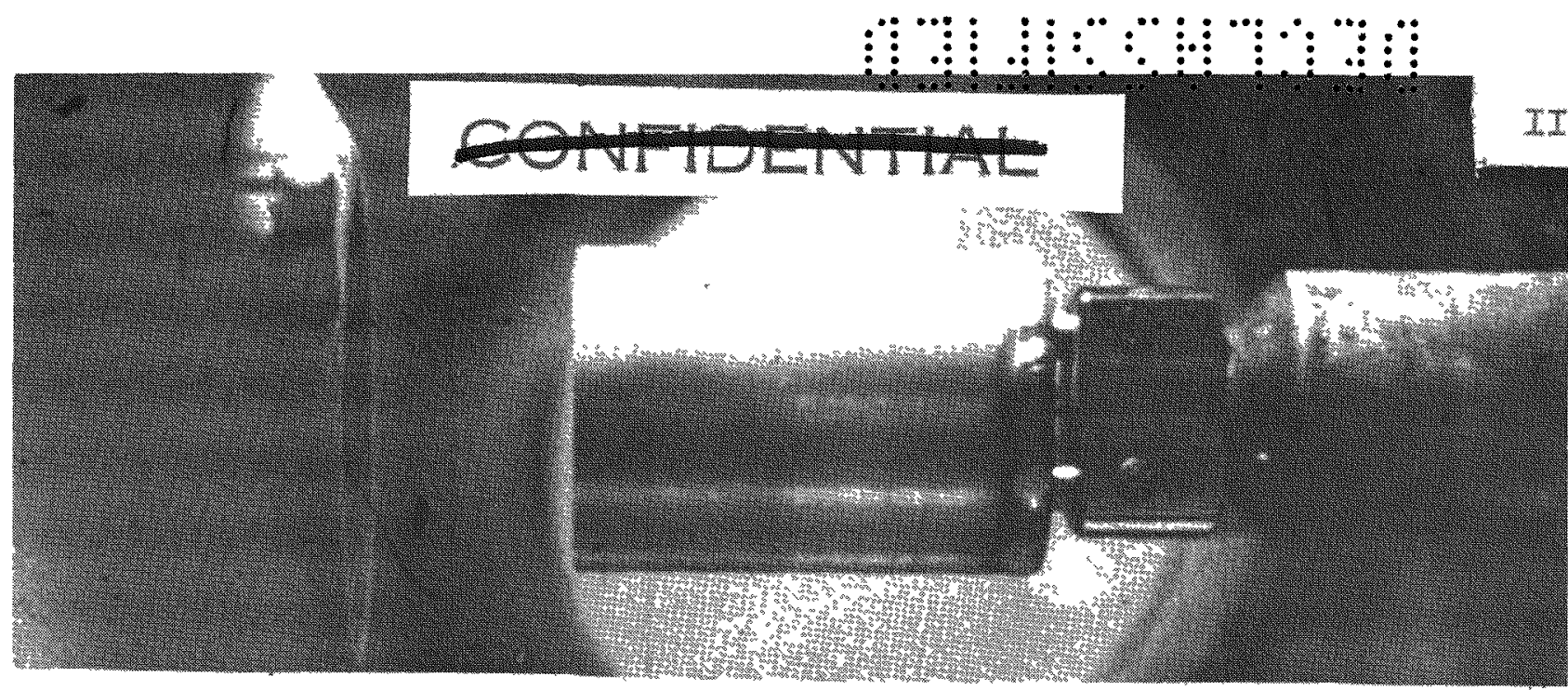

FCURE 91

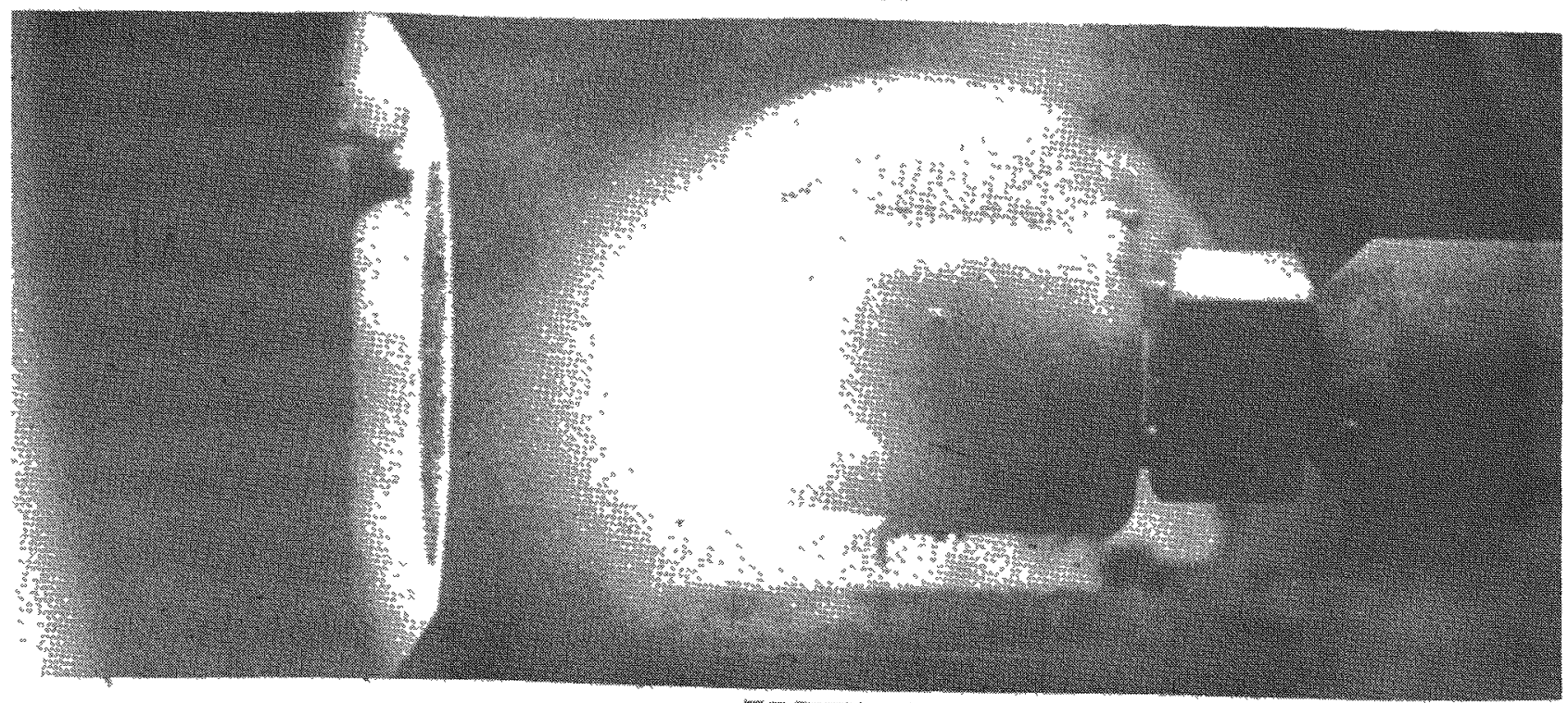

PrGURE 92

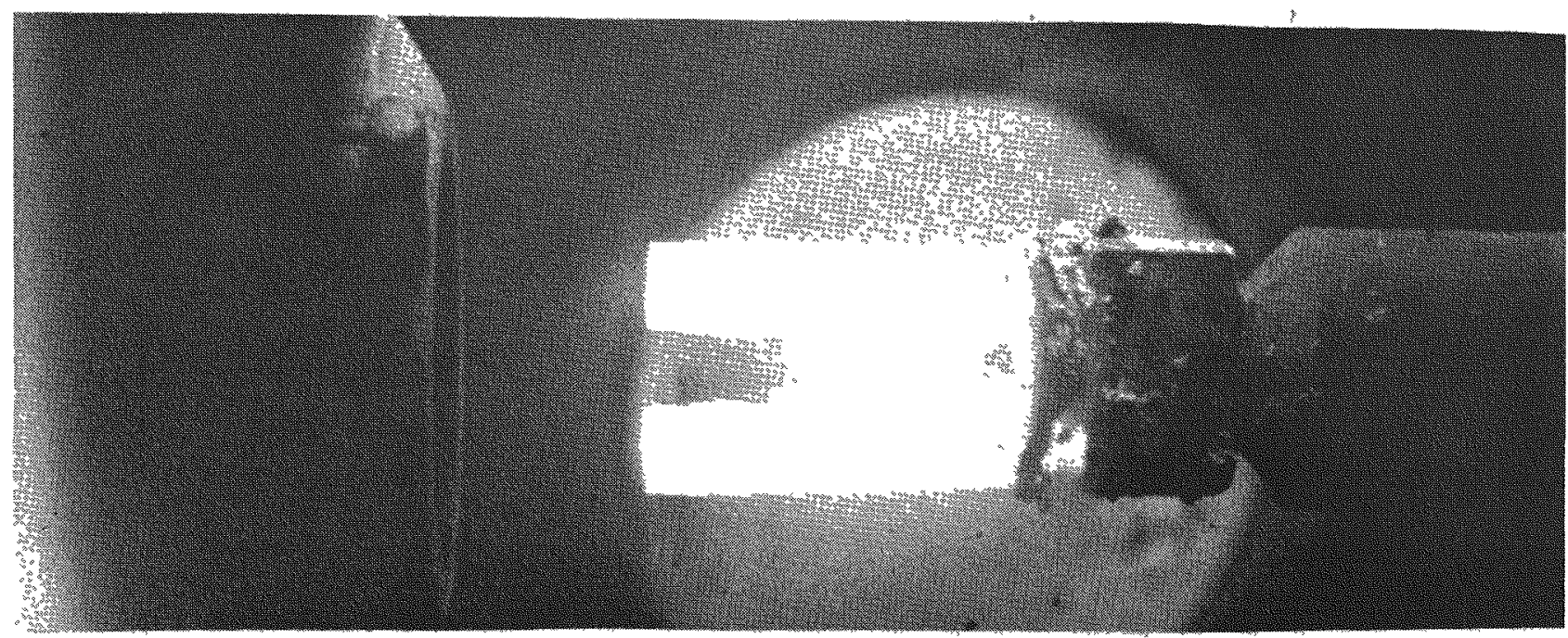

ThURe 95

.4.

PLASUA TEST SPECIMEN GIA-4 IV WW WSA

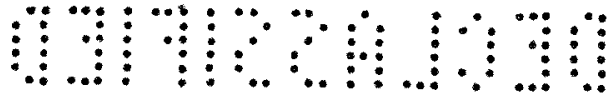




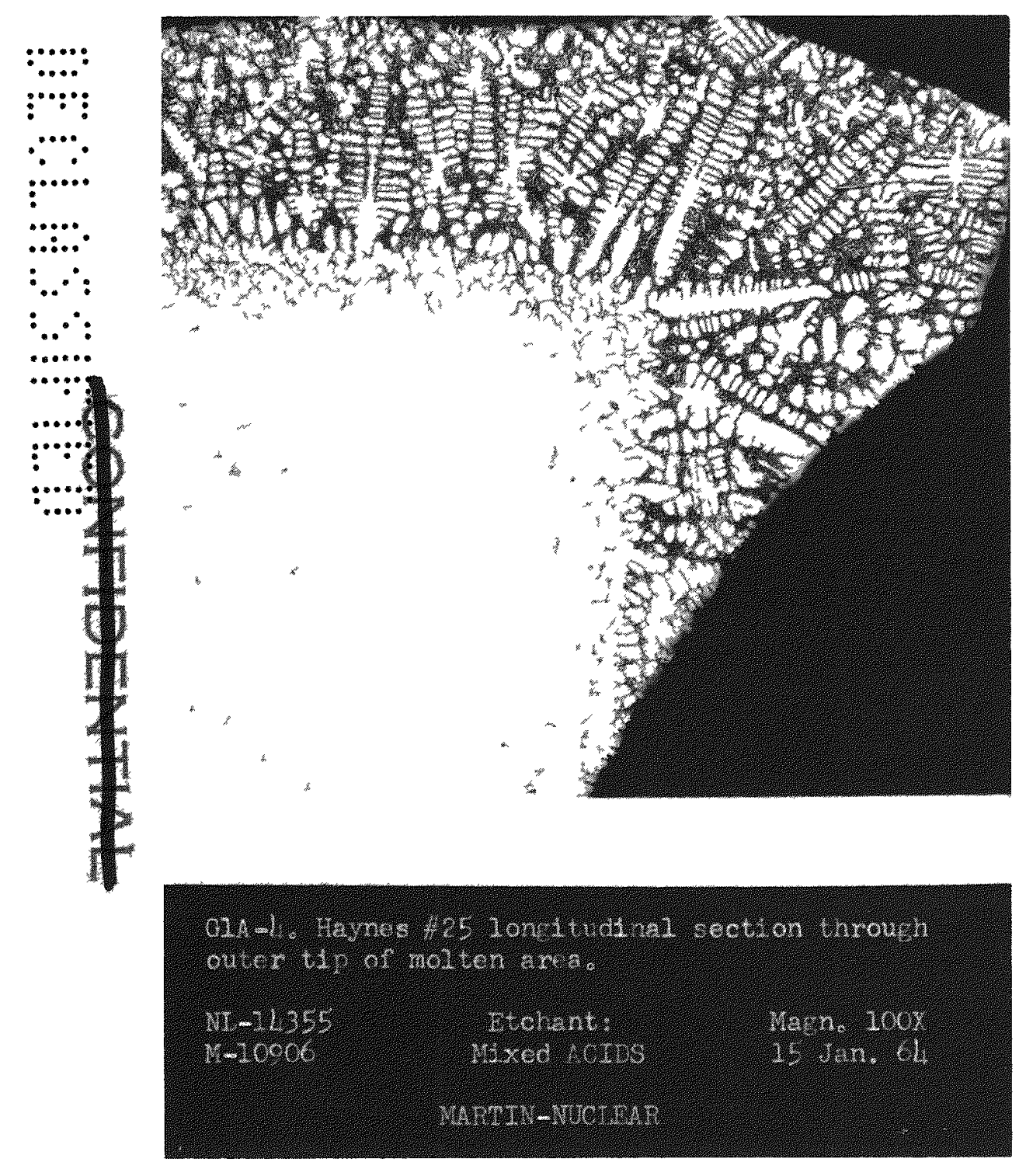

I

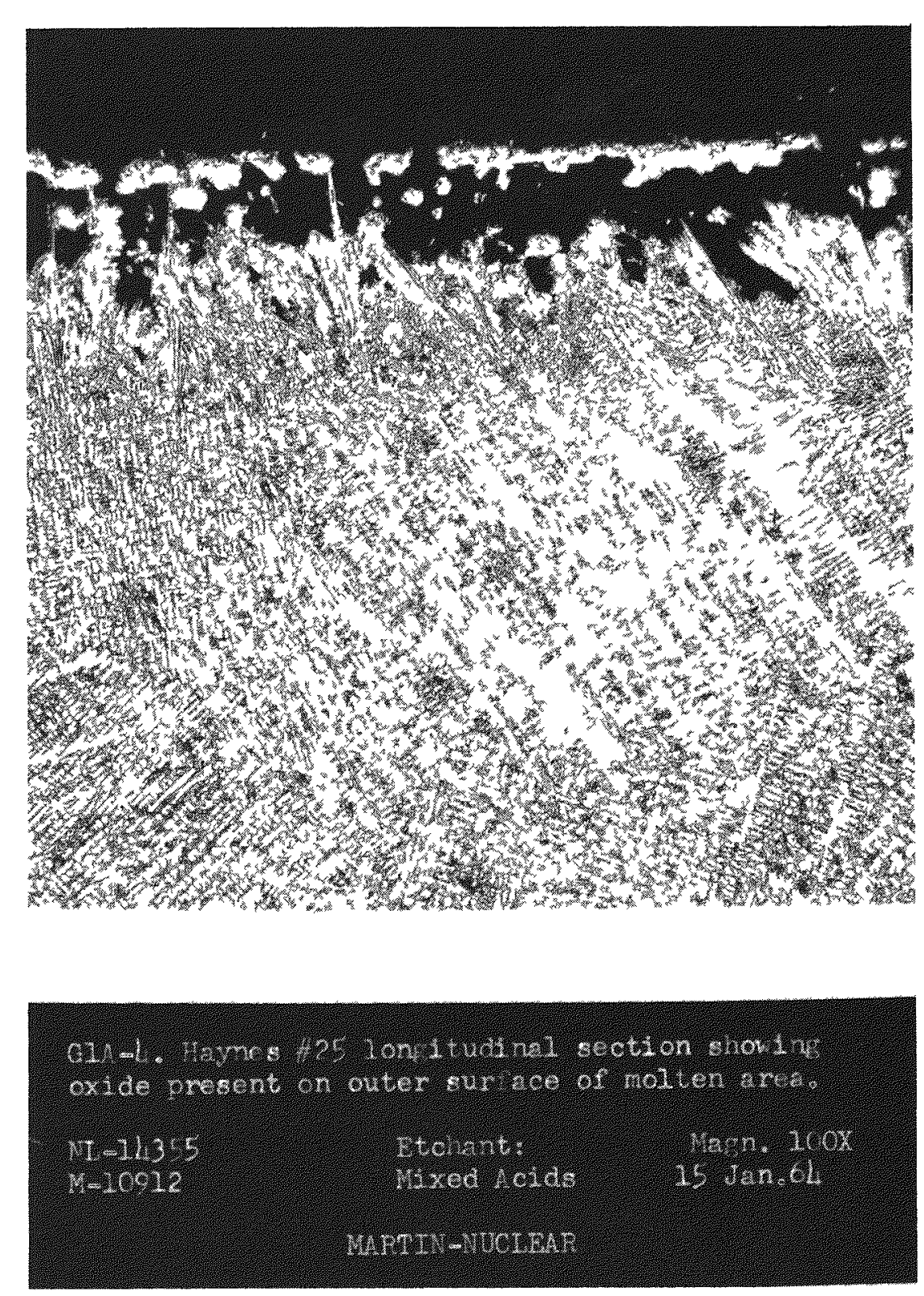

B

FIGURE 94

PLASWA TEST SPLCIML GT-A POST TEST CONDTTION 

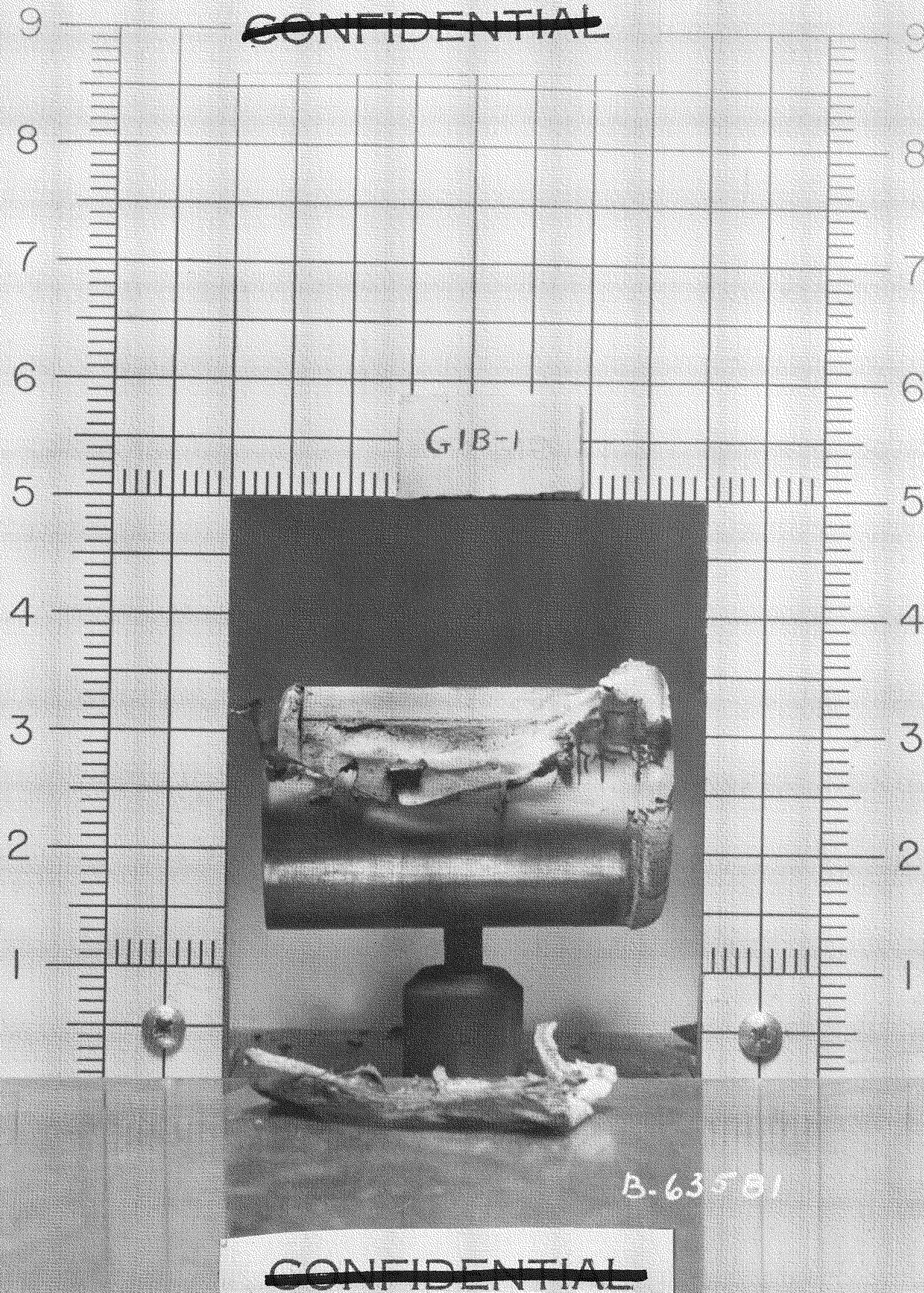

FIGURE 95

PLASMA TEST SPECIMEN GIB-1 POST TEST CONDITION 


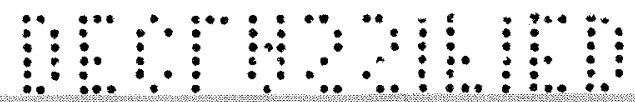

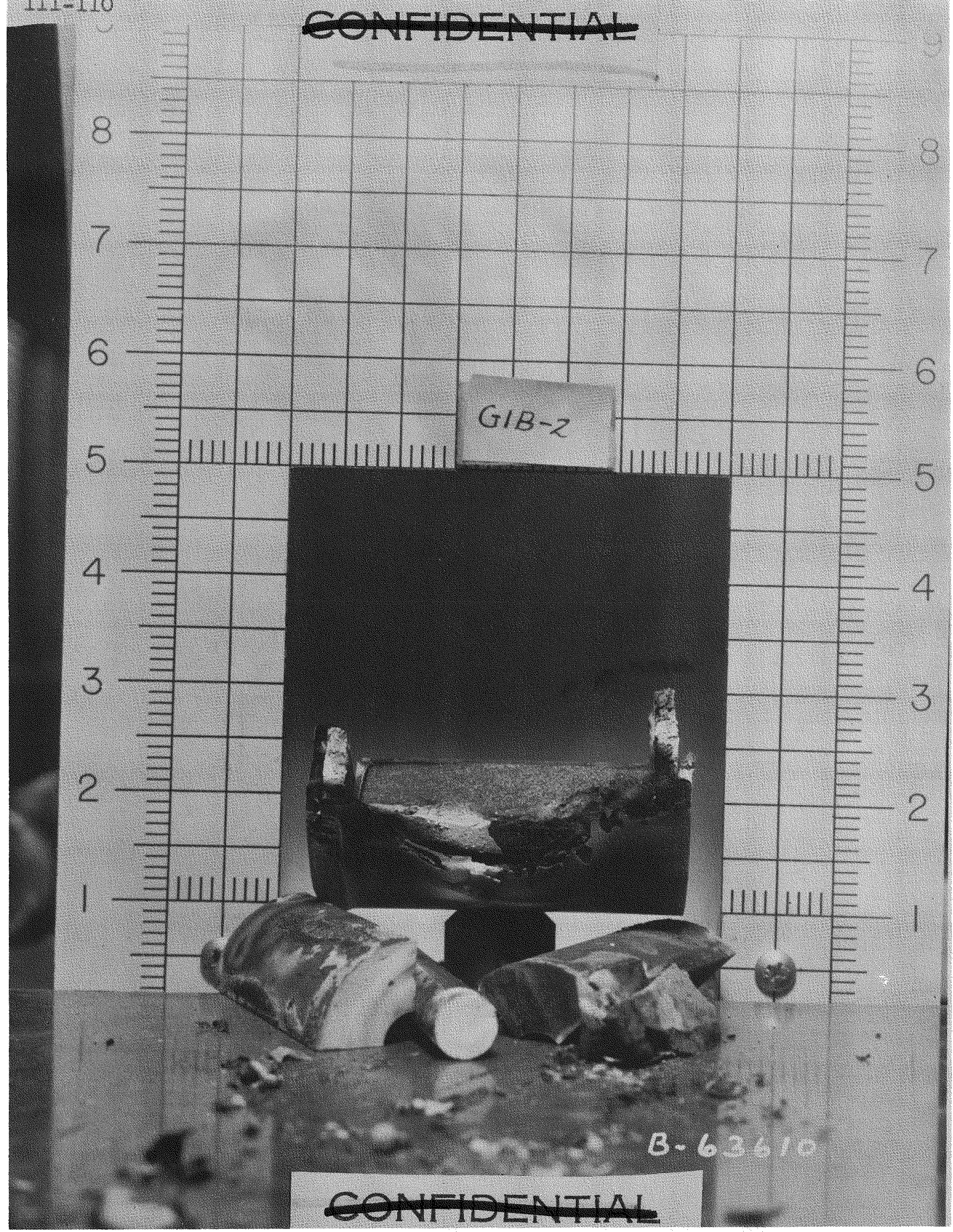




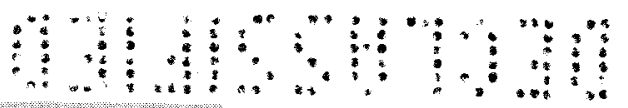

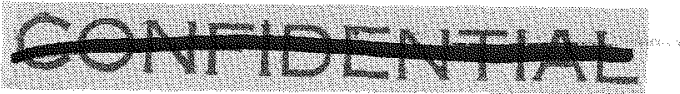

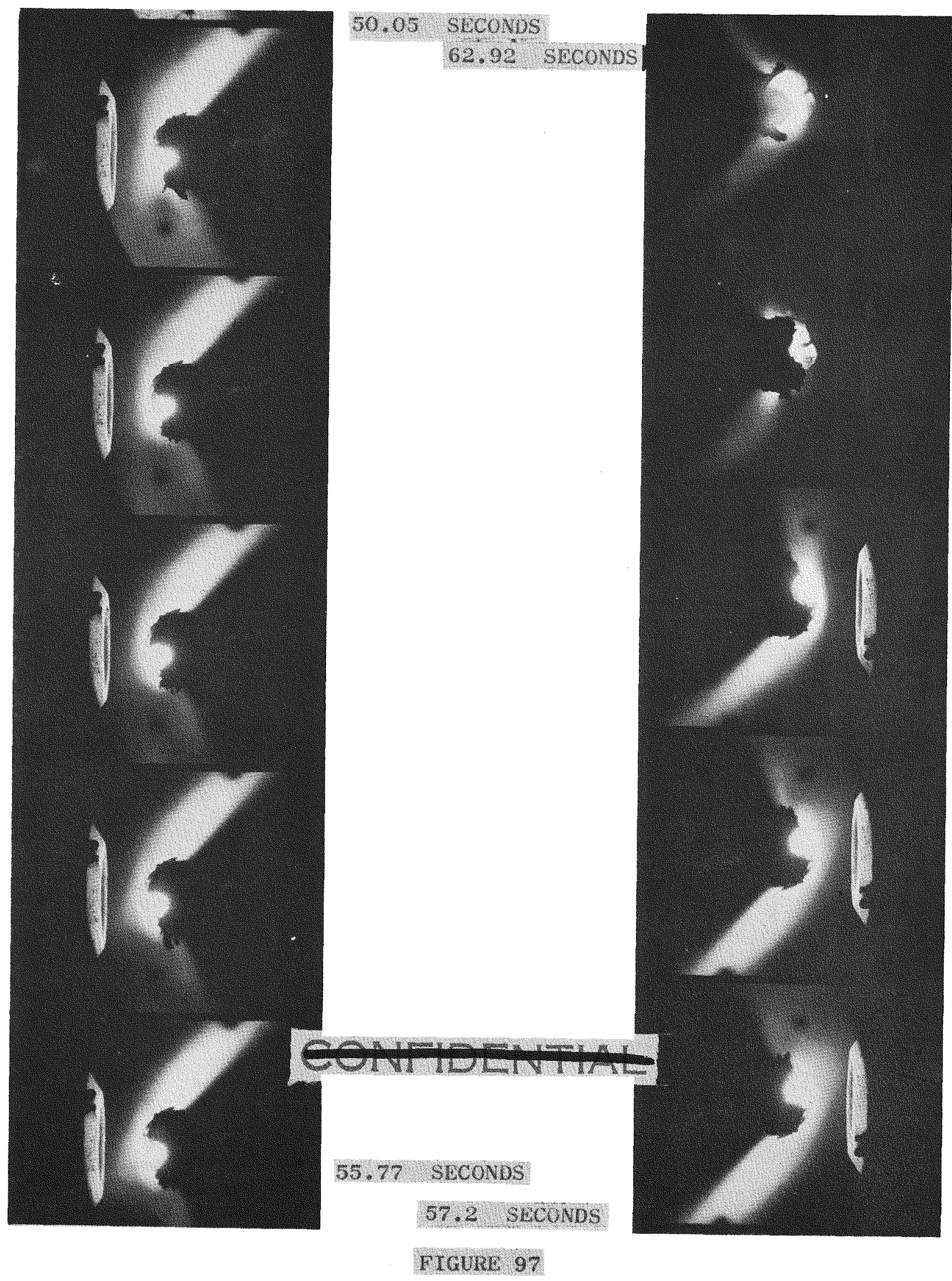

PLASMA TEST SPLCINEN GIB-3 IN PHASMA

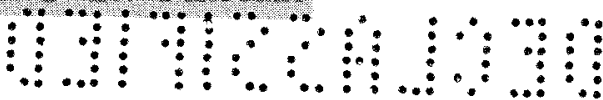


momom

(n)

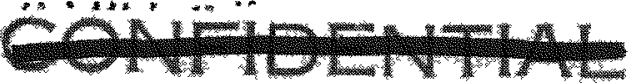

64.35 SECONDS

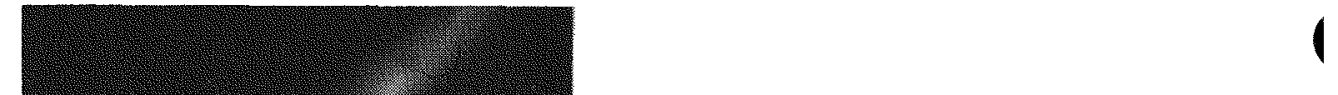

70.07 SECONDS
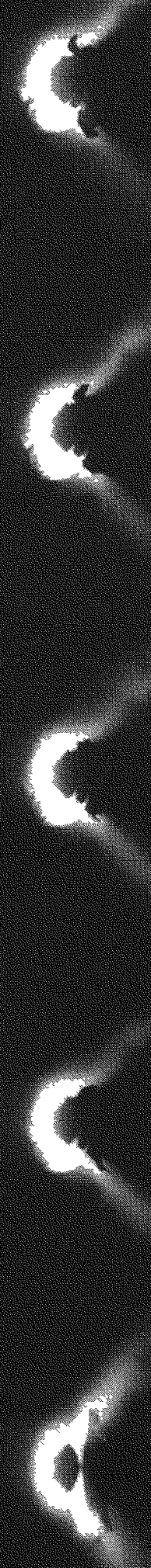


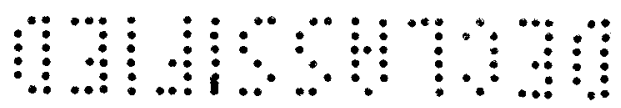
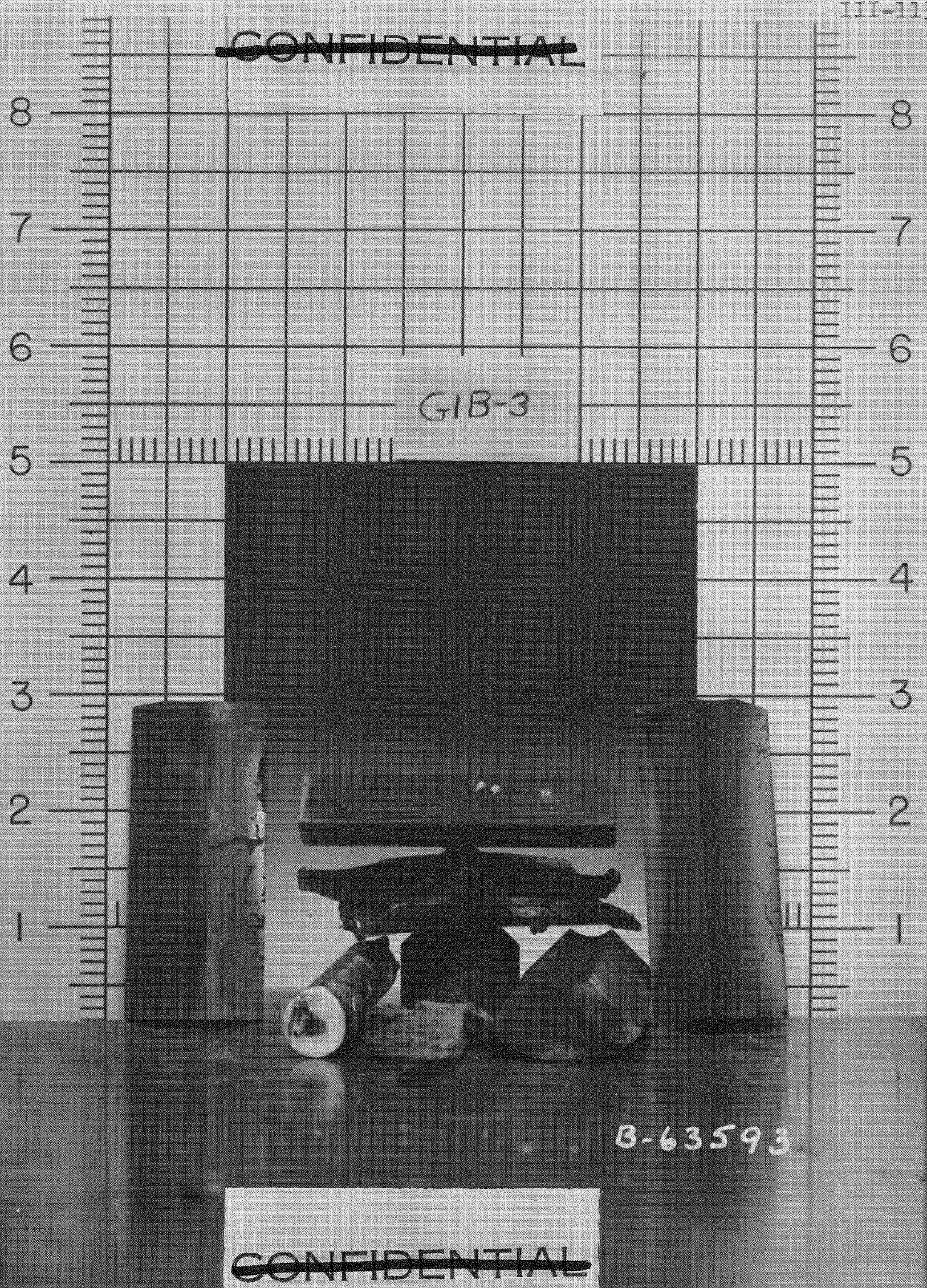

FIGURE 99

PLASMA TEST SPECIMEN GIB-3 POST TEST CONDITION 


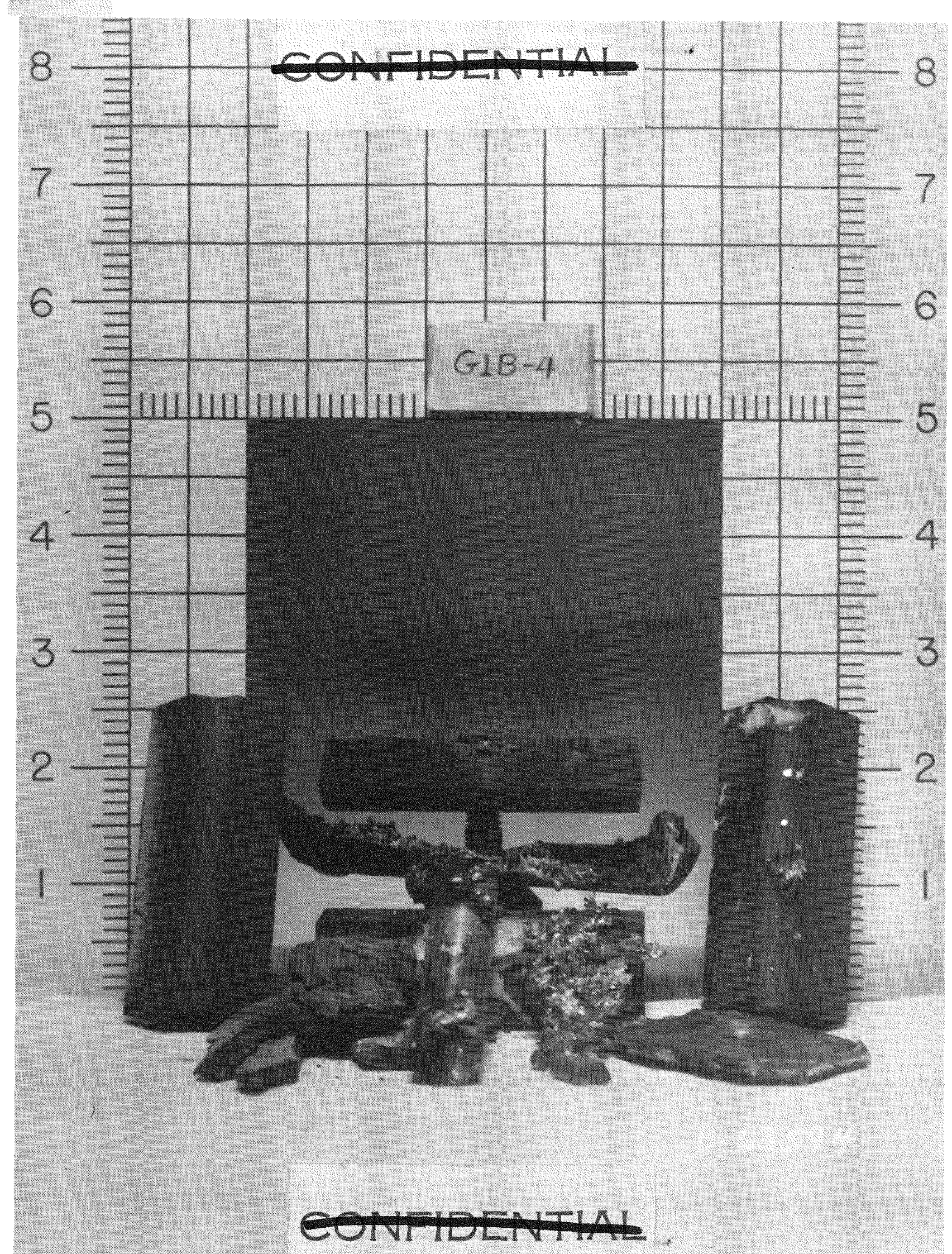

FTCURE 100

PLASMA TEST SPECIMEN GIB-4 POST TEST CONDITION

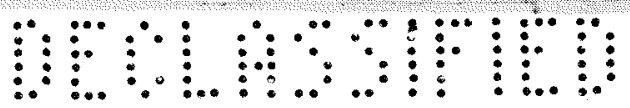




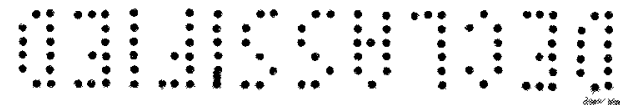

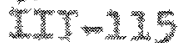

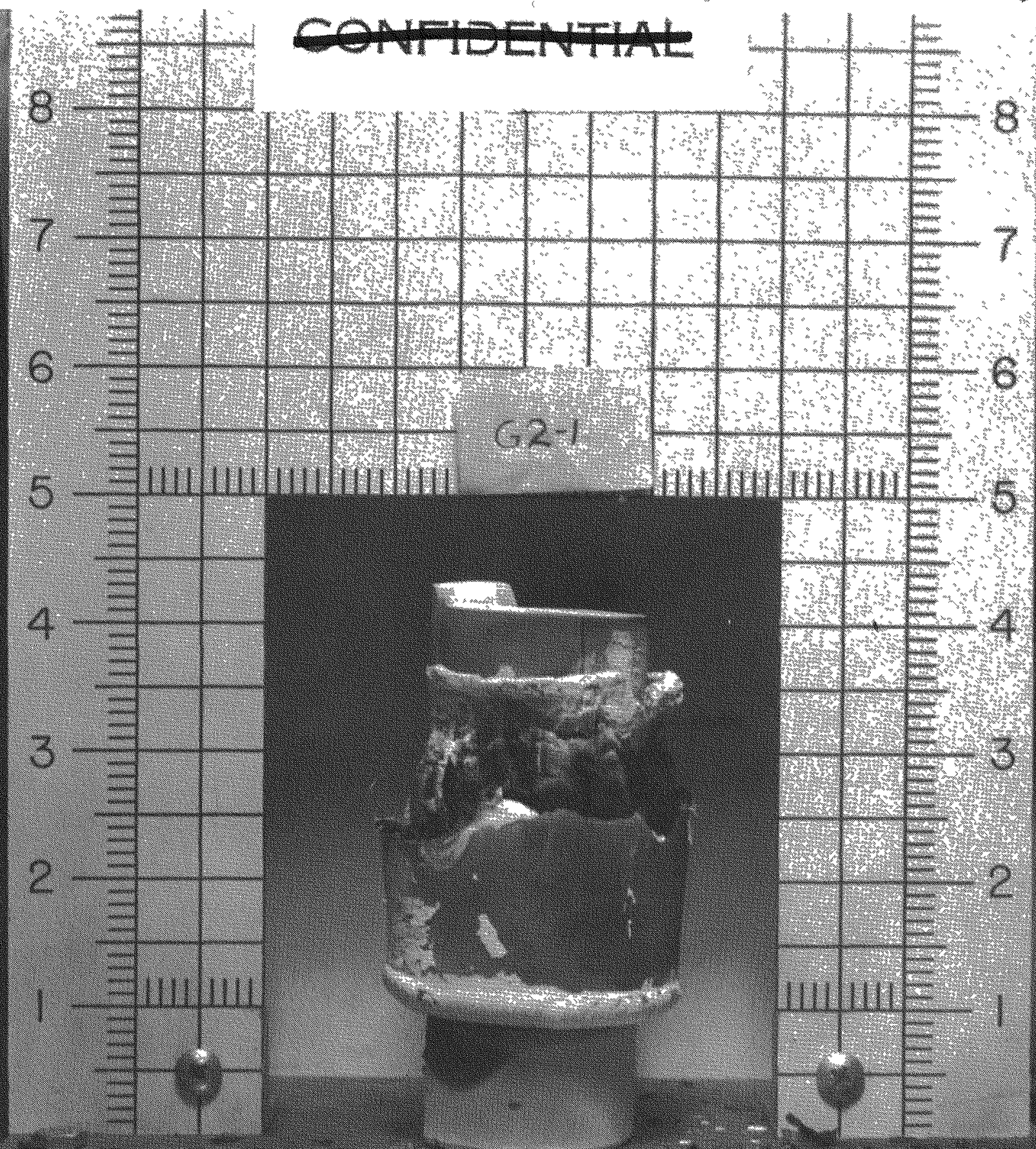

B. 63596

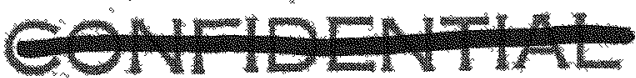

FIGURE 101

PLASMA TEST SPECTMEN Q2-A POST TEST CONDITION 

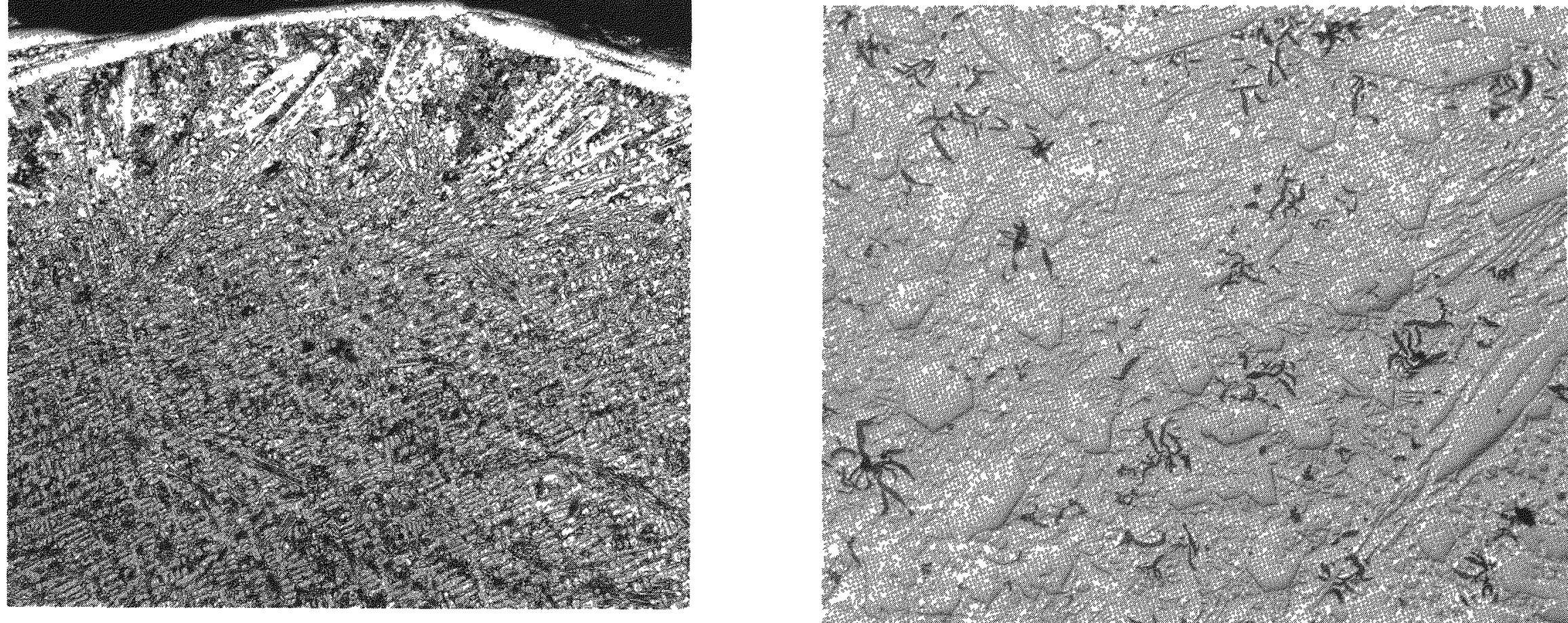

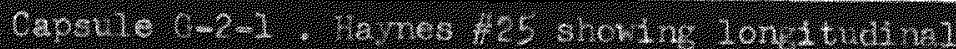
What of moitert aneh.

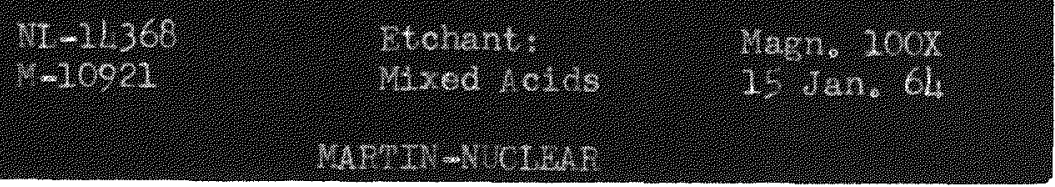

Fatipe 102

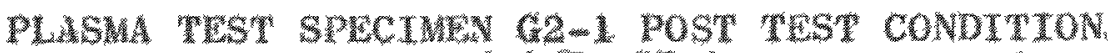
METHLOCAPHY 


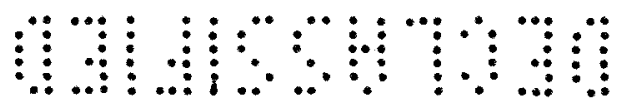

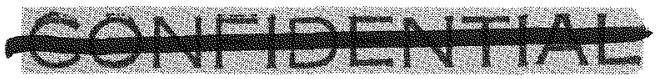

$111-119$

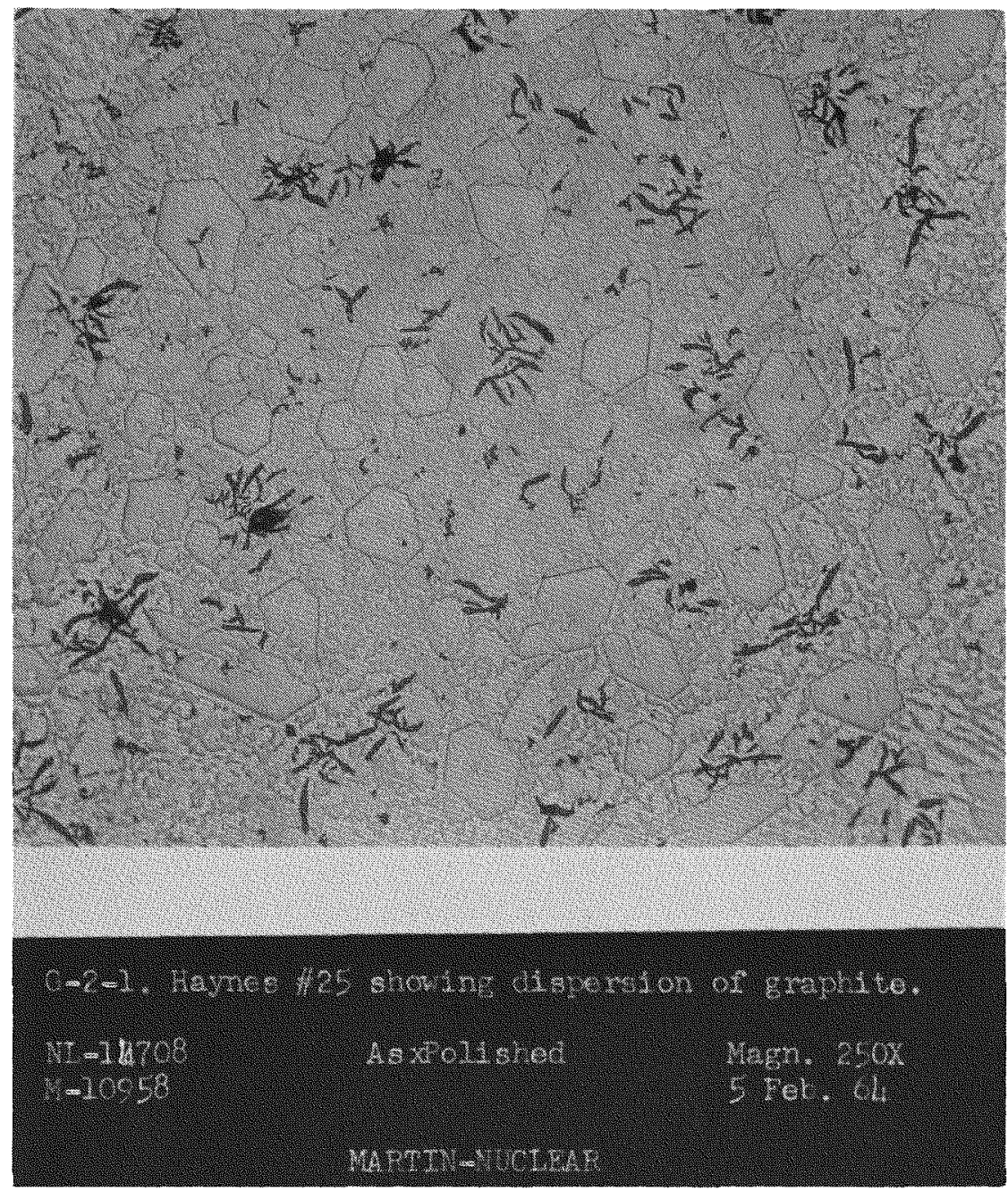

FIOUR 103

PLASMA TEST SPICIMEN G2-1 POST TLST CONDITION MT M IOGR MWH 


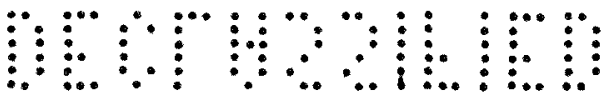

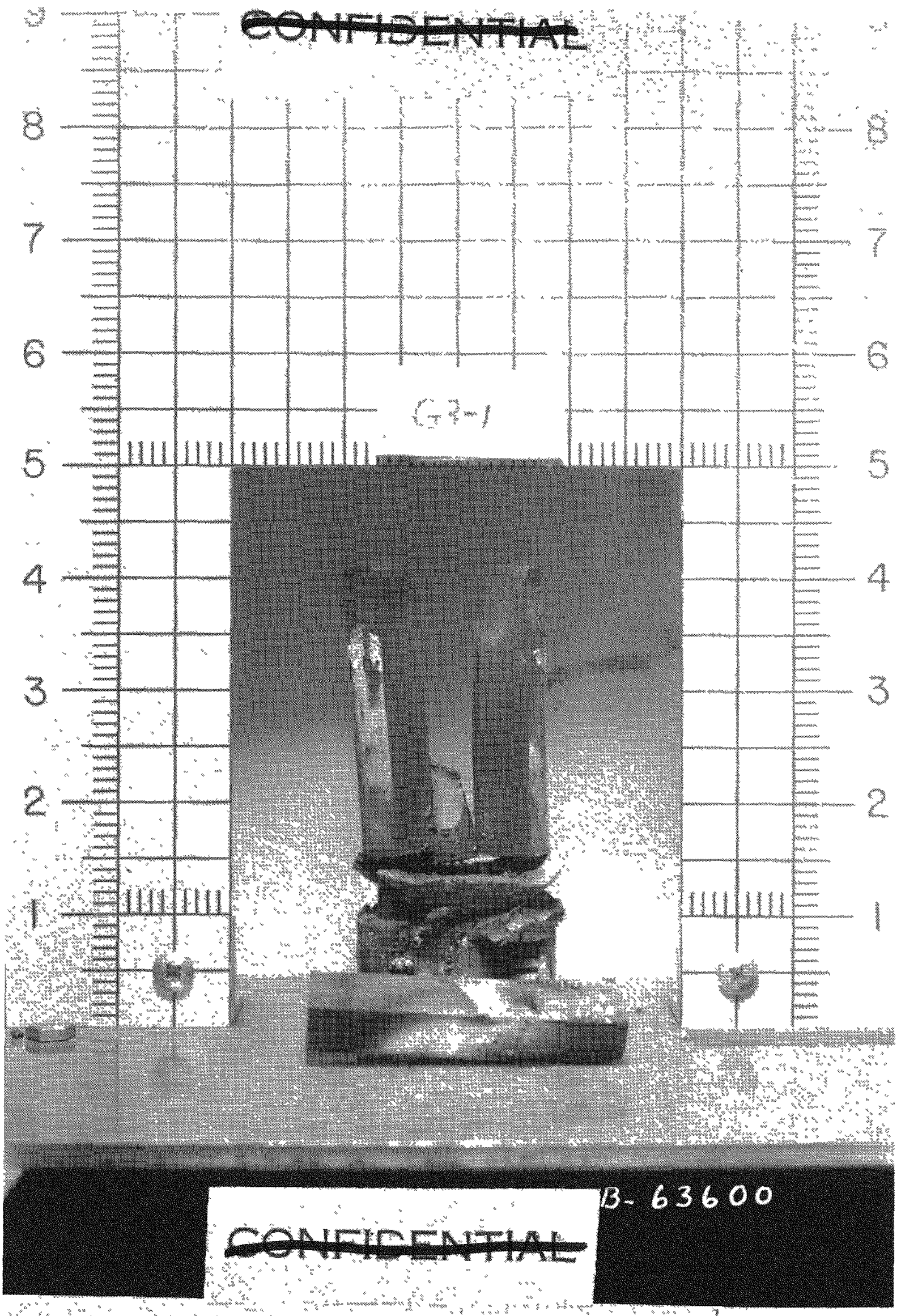

PMCURE 104

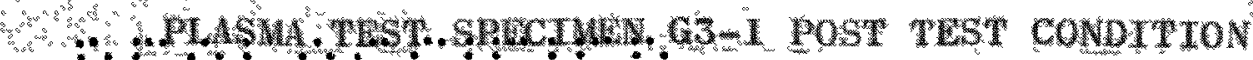

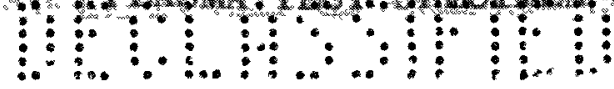




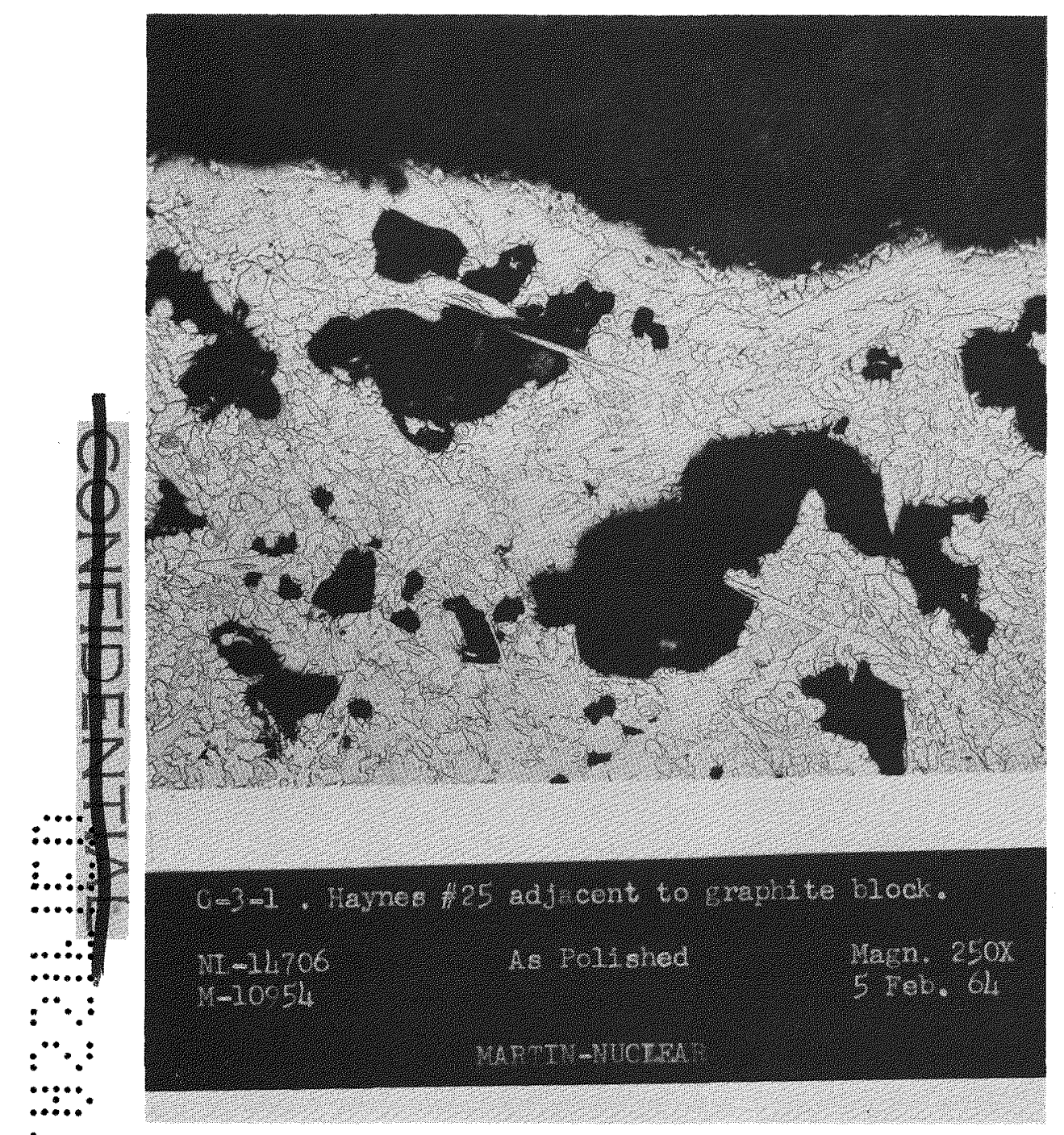

I.

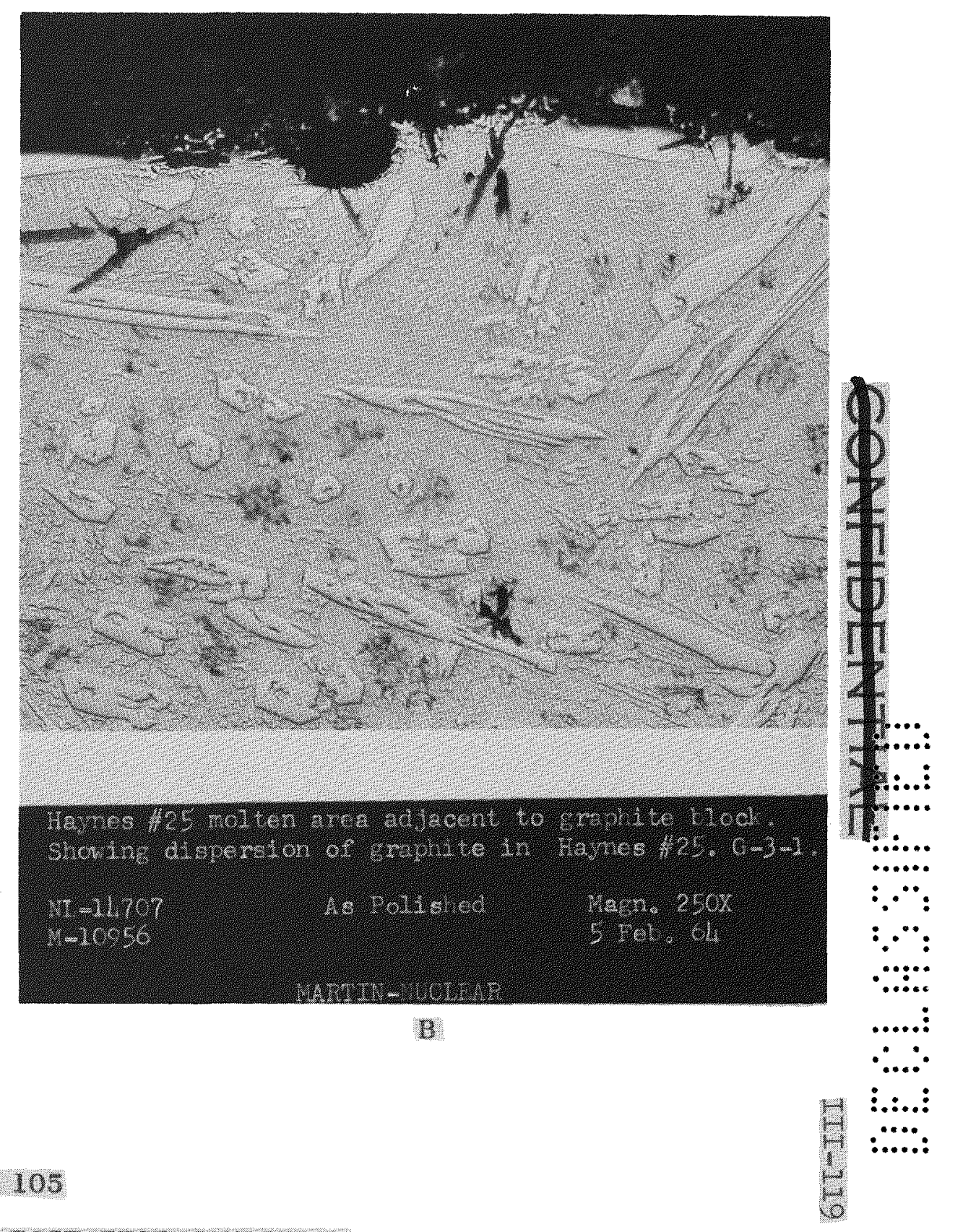

PLASMA TEST SPECIMEN G3-1 POST, TEST CONDITION MatelloGR IPHY 


\section{mblem}

III- 120
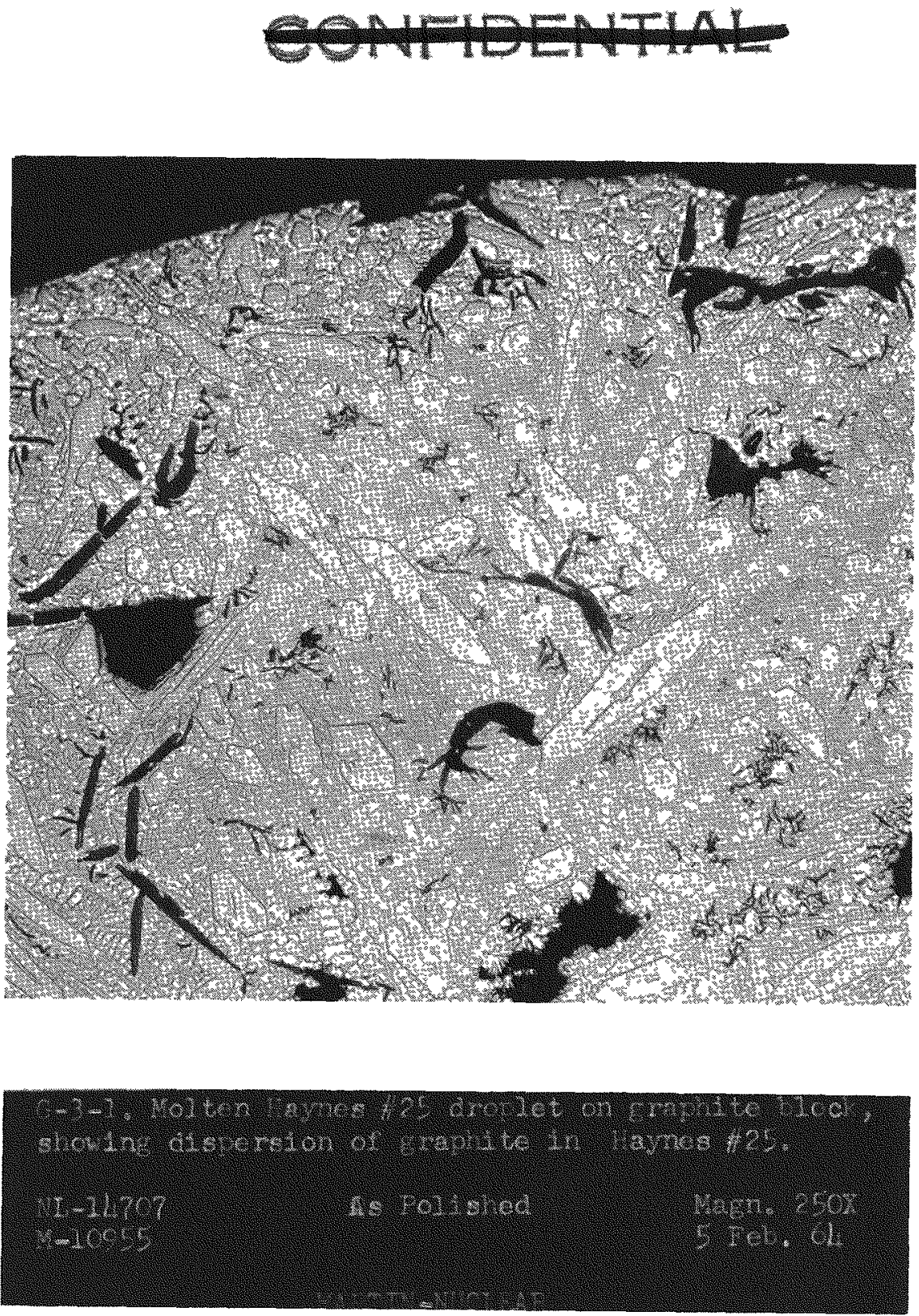

NGURE 106

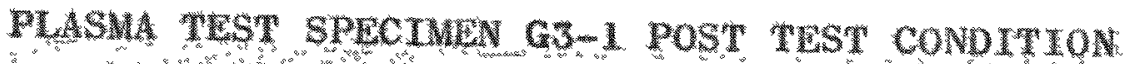
$\therefore$. 


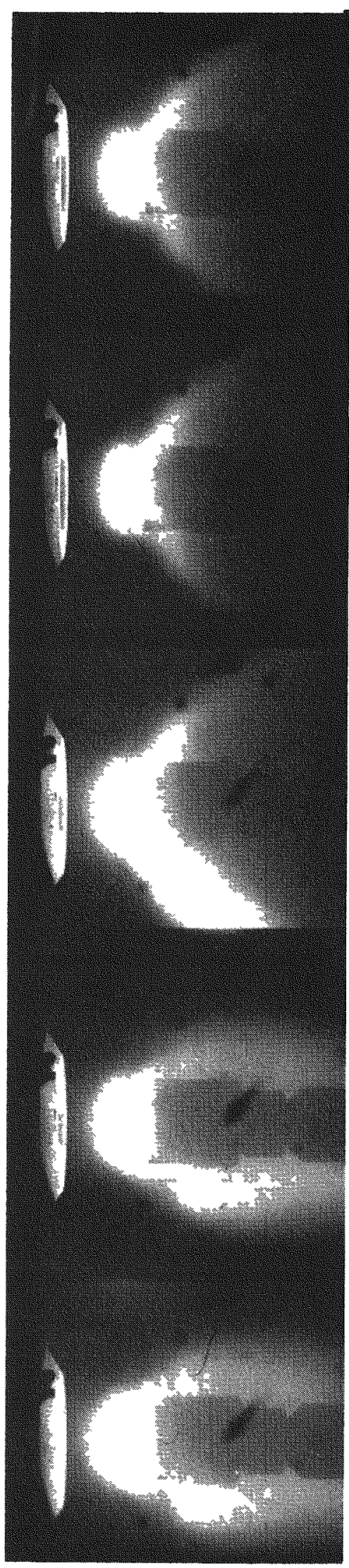

\section{$2 \$ 6.0$ SECONDS}

298.87 sucovus

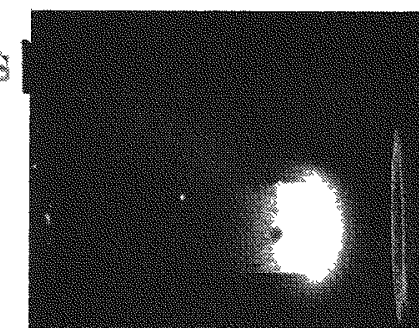

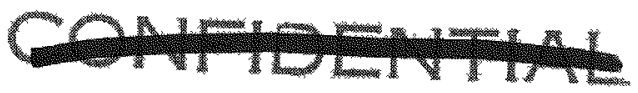

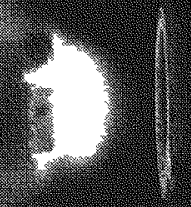

$291.72 \quad 5 \mathrm{ECONDS}$

\section{15 SCONOS}

FIGURE 1.07

PLASM THST SPECTMEN G4A-1.IN.PLASMA

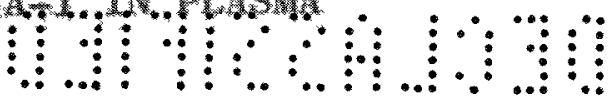



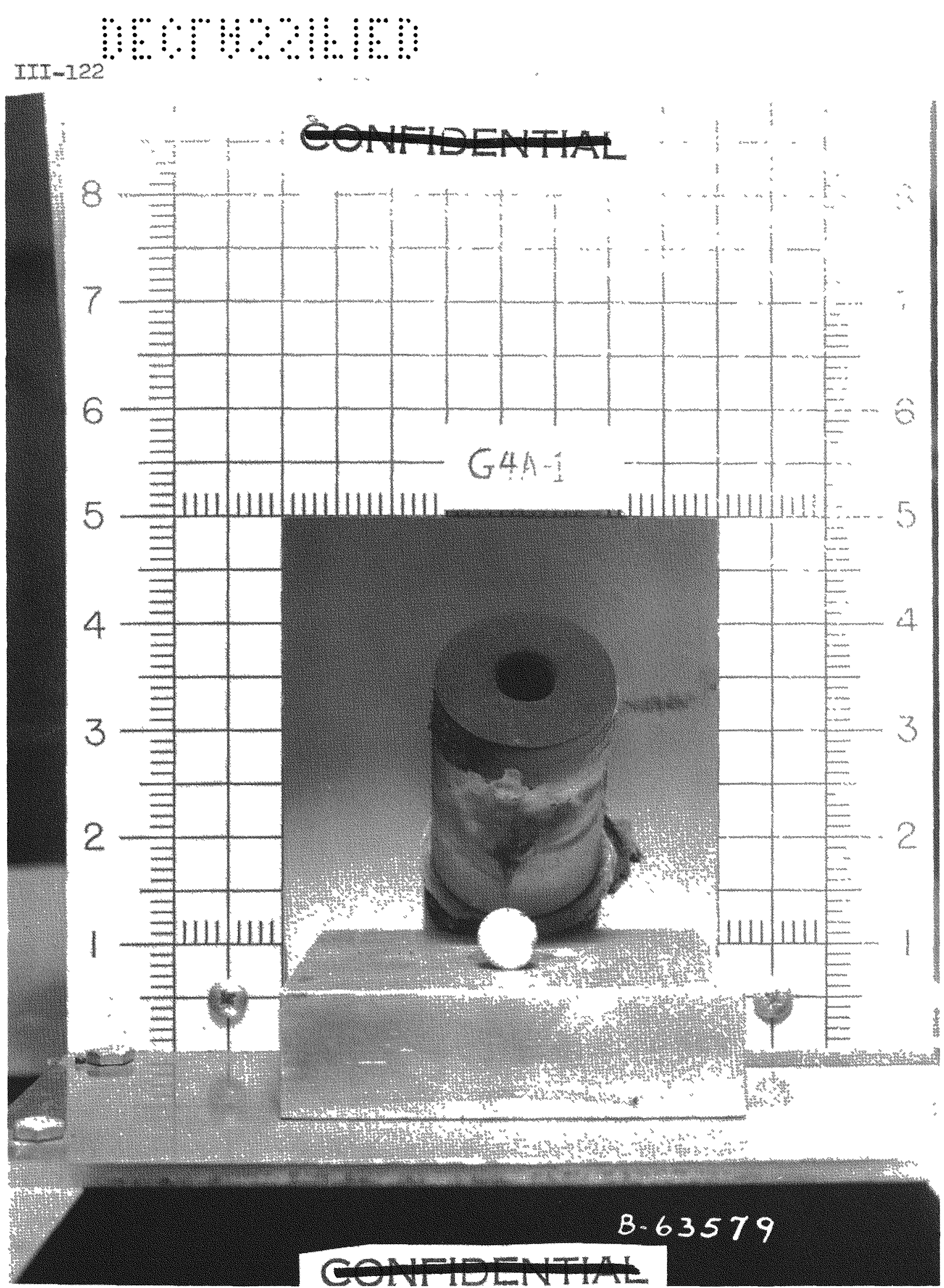

FIGURE 108

PLASMA TEST SPECTMEN G4A-1 POST TEST CONDITION 


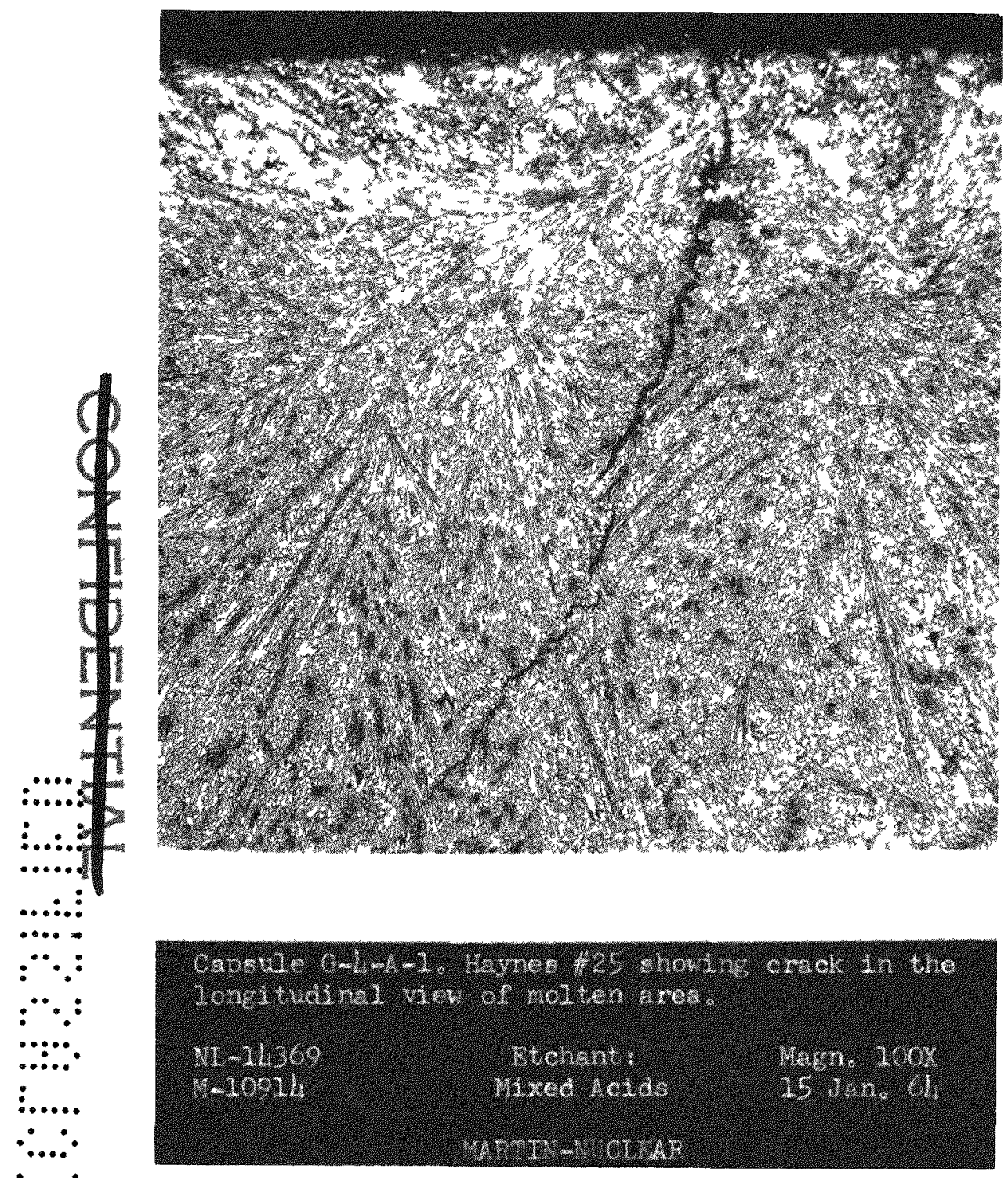

a

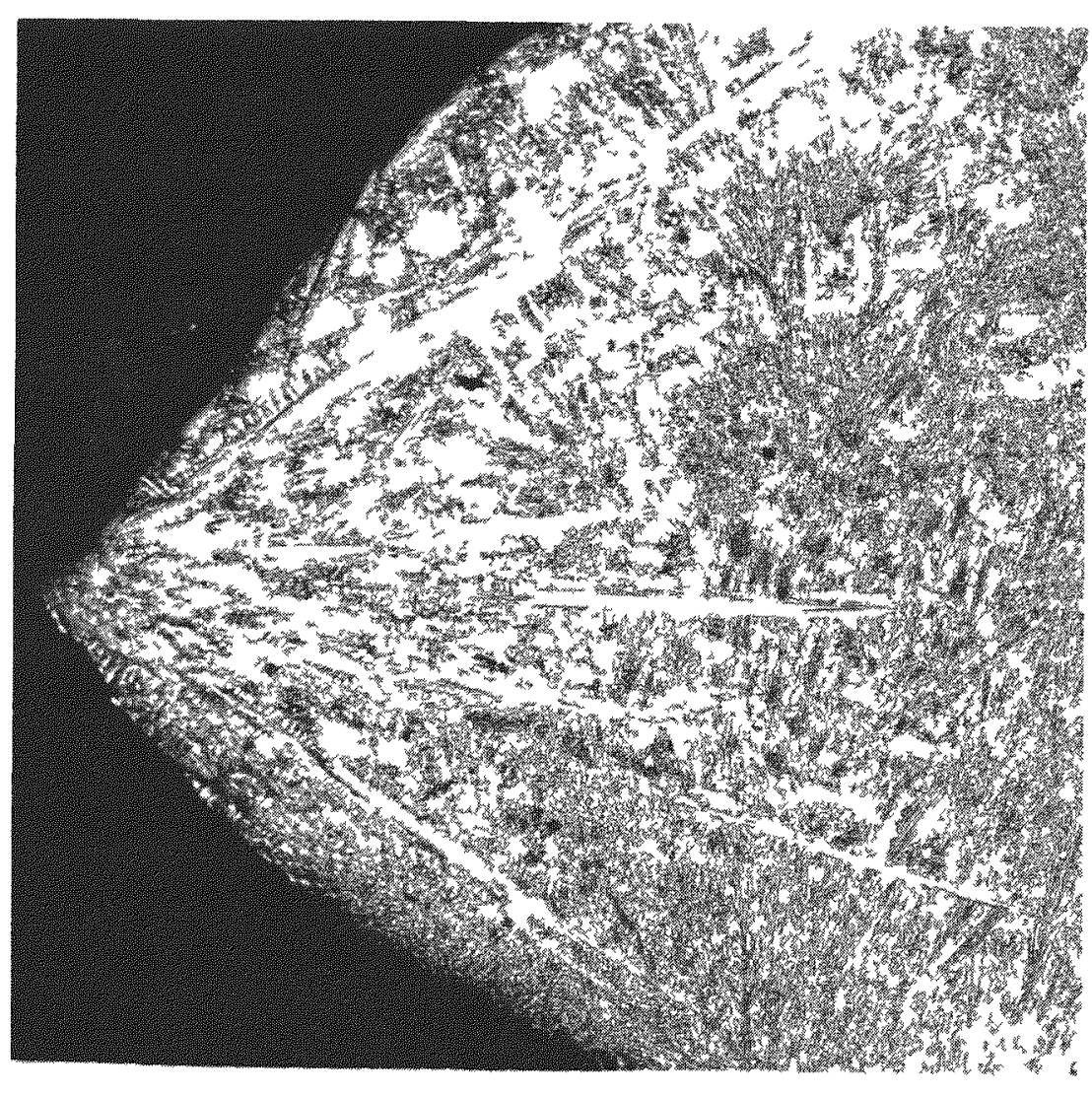

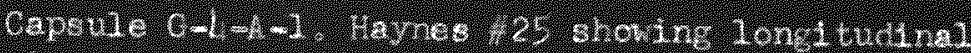
vien of outer most tho.

Ni -11369

re-10935

(2)

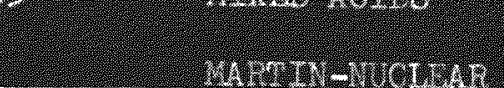

$\mathrm{B}$

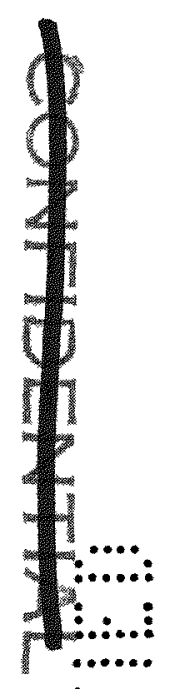

$\vdots \ldots . .$.

$\because . \cdots$

$\because \cdots$

$\because \because: 0$

$\because \ldots$

$\cdots$

$\vdots \ldots .$.

H:...:

FTCURE 109

PLASMA TEST SPECIMLN GAA-1 POST TEST CONDTTION

MET ILLOGRAPHY 


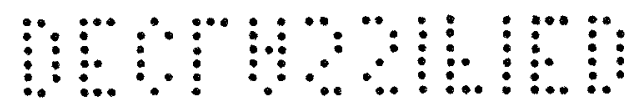

$\operatorname{TII}-124$

\section{CONFIDENTIAL}

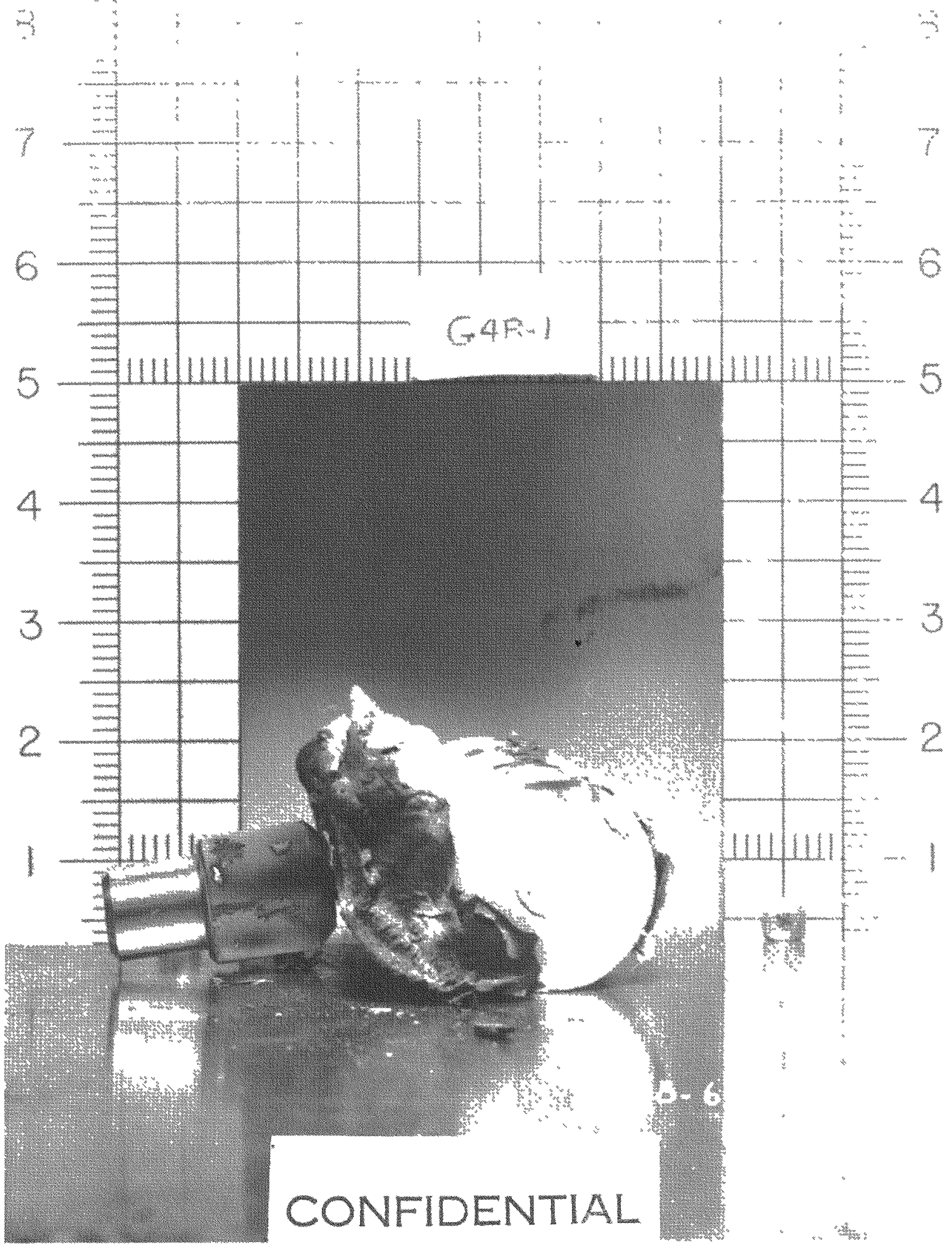

FIGURE 110

PLASMA TEST SPECTMLN GAB-1 PUST TEST CONDITION

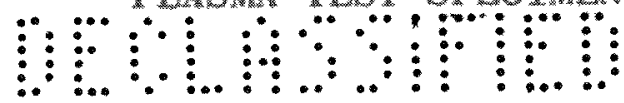




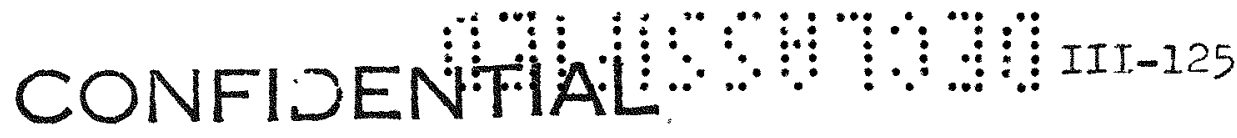

the cold wall heat flux $\left(\stackrel{\circ}{q}_{c w}\right)$ at one inch from the center line for a high value of enthalpy $\left(h_{\mathrm{s}} \cong 8000 \mathrm{BWU} / \mathrm{lb}\right)$ and low mass flow rate $\left(\mathrm{m}_{T}=0.75 \times 10^{-3^{s}} \mathrm{lb} / \mathrm{sec}\right)$ is about $10 \%$ of the center line value. This distribution is Gaussian. For a low enthalpy ( $h_{s} \cong 4000 \mathrm{BNU} / 1 \mathrm{~b}$ ) and a high mass flow rate $\left(\mathrm{m}^{\circ} \mathrm{T} \cong 2.5 \times 10^{-3} \mathrm{lb} / \mathrm{sec}\right)$, the cold wall heat flux $\left(\stackrel{\circ}{q}_{c w}\right)$ at one inch from the center line is now $50 \%$ of the center line value but $\stackrel{\circ}{c w}_{c w}$ attains a maximum intermediate value at 0.25 inches distance from the center line of approximately $400 \%$ of the center line value. Furthermore, the pressure distribution $\left(p_{s}\right)$, tends to follow similar patterns, i.e., the distribution is postulated to be concave or convex, depending on the relative values of enthalpy, mass flow, and input energy. Unlike ${ }^{q}{ }_{c w}$ and $p_{s}$ which are obtained by transducer type probes, $h_{s}$ is obtained by a heat balance method which is the value at the nozzle exit only, and therefore, the enthalpy distribution at the nozzle exit or at some distance from the nozzle is not known.

The X-ray diffraction method for specimen analysis consisted of taking longitudinal cuts of the test specimens at areas where a representative reaction was evident. These sections were polished and mounted in small bakelite cylinders. The polished specimens were then placed on a goniometer of an $X$-ray diffraction unit where it was subjected to radiations impinging on its surface as it was rotated through a $150^{\circ}$ angle at a speed of 2 degrees per minute. These radiations were generated from a copper catbode. Intensity levels were compared with intensity levels of known materials to identify materials present. Bragg's law is the technique used in this type of analysis (Reference 8). The wave length of the incident radiation (from copper in this case) is utilized to 
determine the spacing of the atomic structure by a diffraction method. The diffraction of $X$-rays constitutes reflections, and the relative reflections depend upon the arrangement of the atomic structure of the material. An emission spectroscope was used to supplement and verify the findings of the $X$-ray diffraction unit. Briefly, this consisted of placing powdered particles of the test specimens into a carbon electrode container while another very pure carbon electrode was positioned directly above the powdered granules. A high voltage was placed across the electrodes with a resultant large arc being created which caused the powdered specimens to emit radiant light. This light was then directed through a lense assembly, reflected by a prism, and the resultant spectrum of the incident light generated. From the intensity and spacing of the spectrum, the identity of the material was ascertained. Photographs of longitudinal cuts of various polished specimens were taken to show the unusual grain patterns and interface boundaries created by the simulated re-entry environment. These photographs are referred to in Table 5. The molten areas shown on the photographs were those areas where the longitudinal cuts were taken to form the polished specimens. 
4. Summary of Results

Generator Assemblies

The outer surface of the magnesium shell for all the generators show a magnesium oxide deposit. In the case of GIB-2, a minor phase of magnesium carbide $\left(\mathrm{Mg}_{2} \mathrm{C}_{3}\right)$ was formed with the magnesium oxide. Graphite removed from around Haynes alloy in generator assemblies (GIA-1, $G I A-2, G I A-3, G I A-9, G I B-1, G I B-2, G I B-3, G I B-4, G 4 A-1$, and $G 4 B-1$ ) showed in most cases little evidence of any reactions between the Haynes alloy and the graphite. In G4A-1, which had a reaction product at the surface of the Haynes, the reaction volume was not great. GIA-3 showed a change in the chemical condition of the surface of the Haynes alloy, but also very little reaction with the graphite. On some, there are areas where the molten Haynes had "wetted" the graphite with possible physical intermixing, and possible chemical reactions. In particular, generators $G 3-1$ and $G 2-1$ showed indications of the formation of carbides at and near the irterface of Haynes and graphite. For all the specimens, no nitride compounds were detected, although one would intuitively suspect their existence since high temperatures and a high concentration of nitrogen (approximately 80\%) was inherent in the plasma flame.

Genera.11y, the magnesium generator housing ablated off very rapidly, exposing the Min-K. In models where solid cylinders of Min-K were used, the Min-K exhibited stability and remained on the surface for a period of 150 to 165 seconds, but the graphite heat accumulator and Haynes-25 were being heated. In a very short time, the separable graphite segments broke away from the Haynes-25. This means of separation showed that the 
segmented graphite heat accumulator block had not been welded together by the molten material, even though it was in intimate contact with it. The segments were observed separating, with molten Haynes-25 spiliing out. Small beads of Haynes-25 were found on the graphite segments. After the tests which were metallographically examined, it was found that adherence resulted from surface penetration of the Haynes alloy into the crevices of the graphite and the formation of stable carbides in the alloy and graphite. In no case was there found any graphite-to-graphite bonding, even in the post-test condition. The segmented boron nitride model exhibited similar reactions.

\section{Tantalum Oxidation Models}

The tantalum oxidation models exhibited rather unique oxidation characteristics. The oxide was not continuously removed from the surface, but rather formed an oxide layer on the direct heated surface which varied from 44 to 60 mils in thickness and a similar layer was found on the side of the model. Finger-like fragments extended out from the models in approximately 90 seconds and remained through the duration of the test. The oxide layers exhibited a high degree of stability in the plasma providing a protective coating for the model. Detailing analyses of the specimen revealed a homogeneous phase of $\mathrm{Ta}_{2} \mathrm{O}_{5}$, the high temperature form, which has a melt temperature of $3400^{\circ} \mathrm{F}$. No nitride phase and/or nitrogen were found to exist in the layers. A detailed metallographic analysis is presented in Appendix $B$. 


\section{Tantalum Fuel Liners}

Oxidation of the fuel liners was similar to that of the oxidation models. Breach in liner containment occurred as a result of loss in structural properties due to the oxide formation. Analysis of the oxide on the liners revealed that it consisted of $\mathrm{Ta}_{2} \mathrm{O}_{5}$. A comparison of theoretical computations and test data indicate that the analysis is conservative. Theoretical analyses were made for stable oriented re-entry bodies with constant enthalpy and constant cold wall heat flux equal to that which was measured in the plasma arc.

\section{Fuel Capsule Assemblies}

The outer Haynes-25 material ablated off exposing the inner tantalum liner. No indication was exhibited of Haynes-25 wetting the tantalum liner, changing the latter's oxidation characteristics. On the specimens containing $\mathrm{Al}_{2} \mathrm{O}_{3}$ end caps, which were tested end on, the $\mathrm{Al}_{2} \mathrm{O}_{3}$ melted but the integrity of the capsule was not breached. The was no molten Haynes material exposed to the graphite heat accumulator block. Specimens with the $\mathrm{AI}_{2} \mathrm{O}_{3}$ cap which were tested at $90^{\circ}$ reacted identically to those which did not have the oxide coating. Therefore, the addition of $\mathrm{Al}_{2} \mathrm{O}_{3}$ on the ends of the capsules will not prevent total burnup of the capsule. It just delays melting if the capsule is oriented in a stable $0^{\circ}$ attitude during re-entry.

\section{E. CONCLUSIONS}

In conclusions, the plasma tests indicated:

(I) The oxidation characteristics of tantalum do not appear to be affected by surface wetting of Haynes-25. 
(2) The ablation rate of tantalum is faster than that which is currently being computed by an oxidation technique.

(3) Based on the test data, capsules containing a 20 mil tantalum liner on the RFD-2 experiment should burn up and expose flare materials.

(4) The computed ablation rate of Haynes-25 was, for all practical purposes, the same as the ablation rate experienced in the test, Table 5.

(5) $\mathrm{Al}_{2} \mathrm{O}_{3}$ oxide caps on the capsules will delay the melting of Haynes-25 long enough so that the heat accumulator block wil separate without being exposed to molten capsule material.

(6) The $\mathrm{Al}_{2} \mathrm{O}_{3}$ caps will not change the burnup characteristics of the capsule after it is freed from the heat accumulator block and tumbling during re-entry.

(7) Zirconium foil used in two of the generator models tested did not add any support in aiding the heat accumulator block to secarate.

(8) The generator housing ablates very rapidly; however, its rate is not exothermic. That is, it melts away as predicted by thermal analysis, Table 5.

(9) The graphite heat accumulator segments are not welded together as a result of intimate contact with molten Haynes material.

(10) Graphite is a better heat accumulator block material than boron nitride. 
(11) Haynes-25 melts and is released from an unsegmented block of graphite under simulated re-entry conditions. That is, if the graphite block did not separate, there is a very good possibility that all of the capsule material and fuel contained in the block would be released during re-entry. 


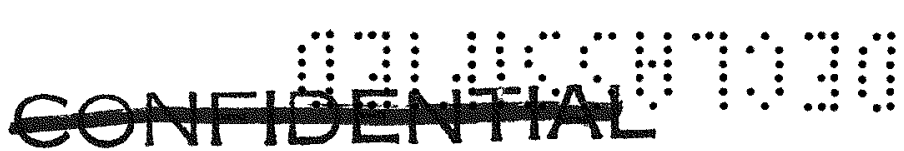

\section{WIND TUNNEI TEST}

A series of wind tunnel tests were conducted to measure separating force moments and to observe disassembly of the RFD-2 graphite heat accumulator block. These tests were designed to evaluate the forces acting on two different heat accumulator block configurations at angles of attack and to record the behavior of a full scale heat accumulator block under simulated re-entry conditions at a zero degree angle of attack. A total of 15 tests were run, 12 on force models and 3 on actual flight hardware with simulated fuel capsules. The test environment simulated a re-entry condition equivalent to an altitude of approximately 200,000 feet and a velocity of approximately $\mathrm{Mach}$ 20. High speed motion picture cameras were used to record the action.

\section{A. TEST FACILITY}

The wind tunnel tests were conducted in the Experimental Fluid Mechanics Hypersonic Facility. This facility, sometimes referred to as the hot shot tunnel, is a heated hypervelocity blowdown wind tunnel with a 25-inch diameter test section. It is capable of simulating environmental conditions in a re-entry flight corridor of altitudes from 140,000 feet to 240,000 feet and Mach numbers from 15 to 24. To control the environmental conditions, the facility has a variable electrical energy and voltage source. This energy source consist of 265 capacitors capable of storing 800,000 joules of energy. The voltage source has an upper range of 12,000 volts. Although the running time for the hot shot tunnel is from about 20 to $100 \mathrm{milliseconds,} \mathrm{there}$ is sufficient time to obtain force and moment data through 
the use of normal strain gage balances, pressure data using small transducers, and heat transfer rates using miniatureized thermocouple gages.

\section{B. TEST SPECIMENS AND PROCEDURES}

Two test specimens were used in this program, a freeflight model and a force model. The free-flight model consisted of the actual heat accumulator block with simulated fuel capsules, Figure 111. The block was painted white and the fuel capsules were marked to facilitate photographic coverage and observations. Duxing the three tests conducted on this block, the fuel capsules were positioned in two different locations as shown in Figure 111. The recessed configuration represented the capsules with the aluminum oxide caps removed.

The force model was constructed of aluminum and molded tooling plastic. Figure 112 shows the flushed model configuration and Figure 113 shows the recessed model configuration. Both photographs show the instrumentation lead wires emerging from the rear of the model and the sting assembly which was used to hold the model in the air stream at various angles of attack. The leads are connected to load measuring flexures to measure forces normal to the model sides shown in Figure 114.

The free flight model was suspended in the tunnel by nylon thread. This thread is melted away very early when exposed to the initial shock wave, leaving the model free in the air-stream. The action was recorded on $16 \mathrm{~mm}$ film taken by a Fastax camera operating at a speed of 8000 frames per second. 


\section{मा०

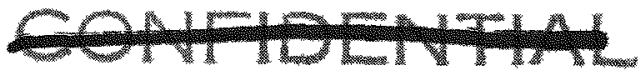
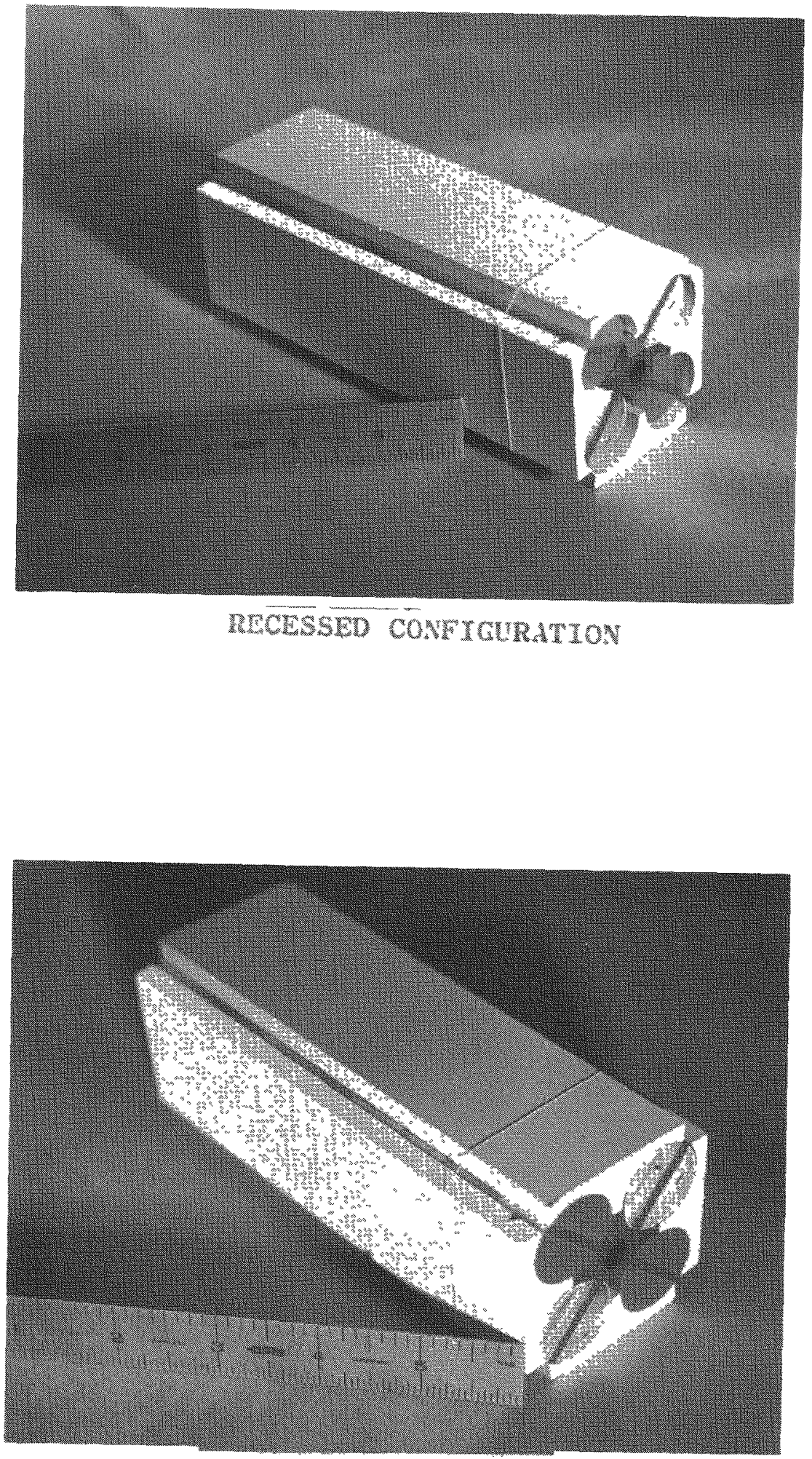

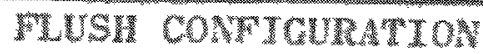

\section{FGURE 11.1}

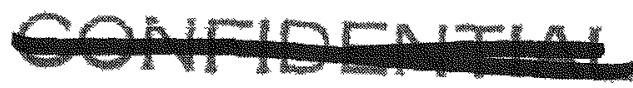

MRE 


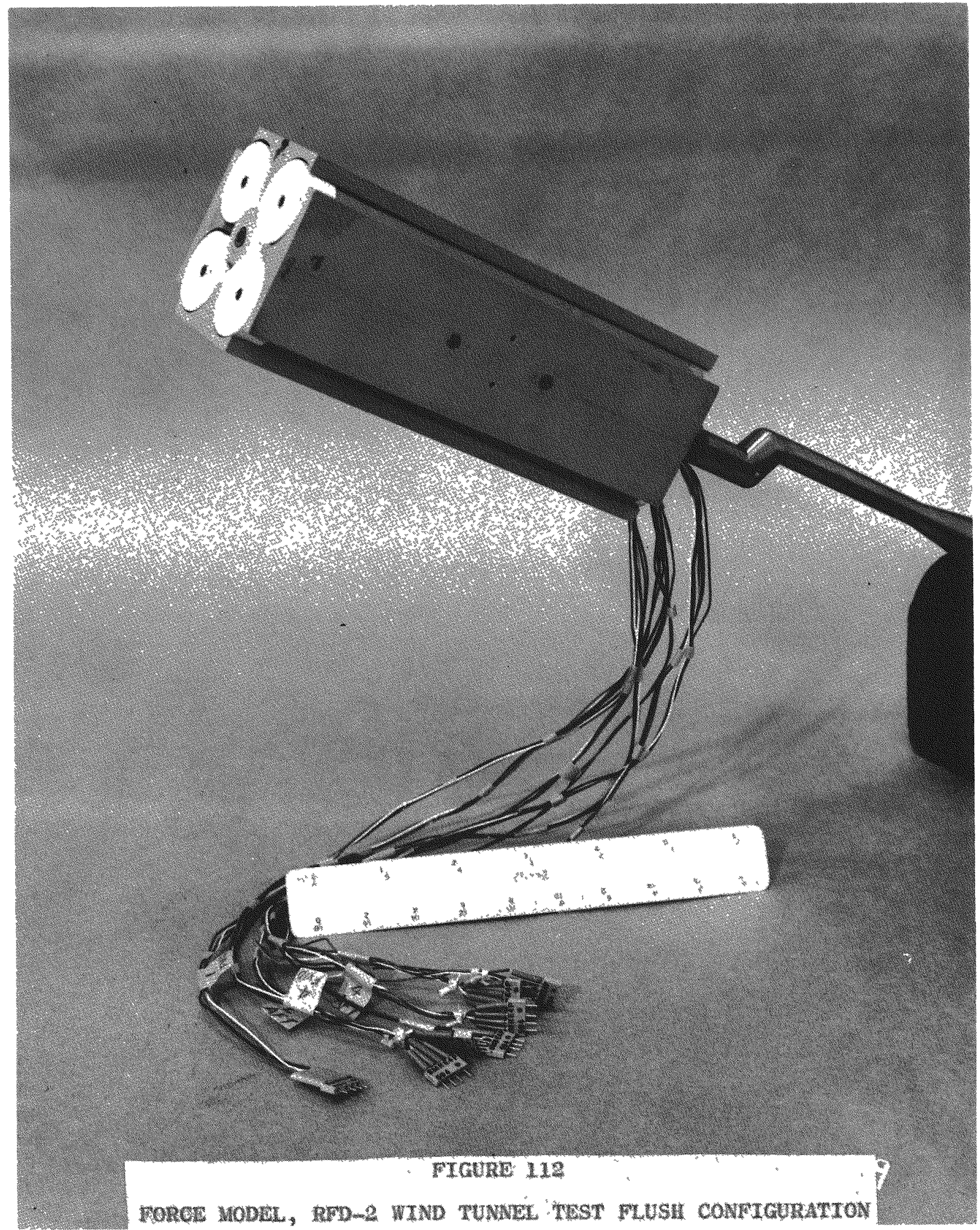




\section{प⿺⿻十⺝丶}

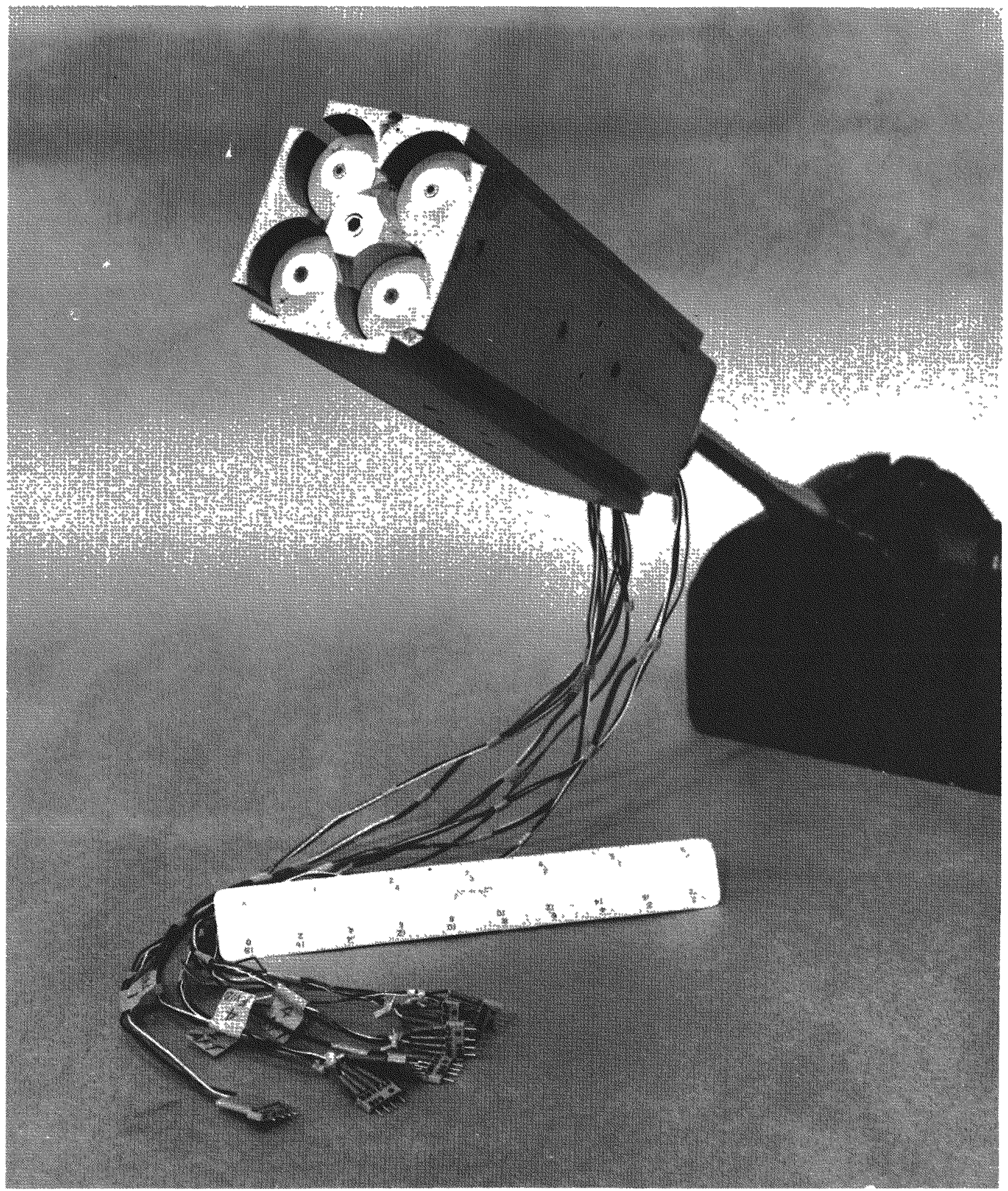

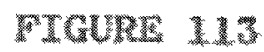

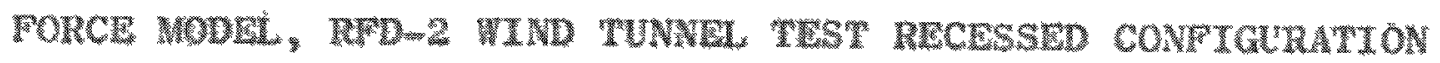

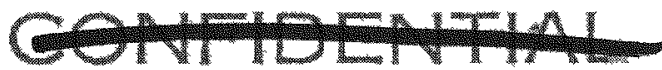

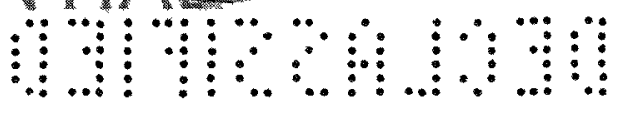




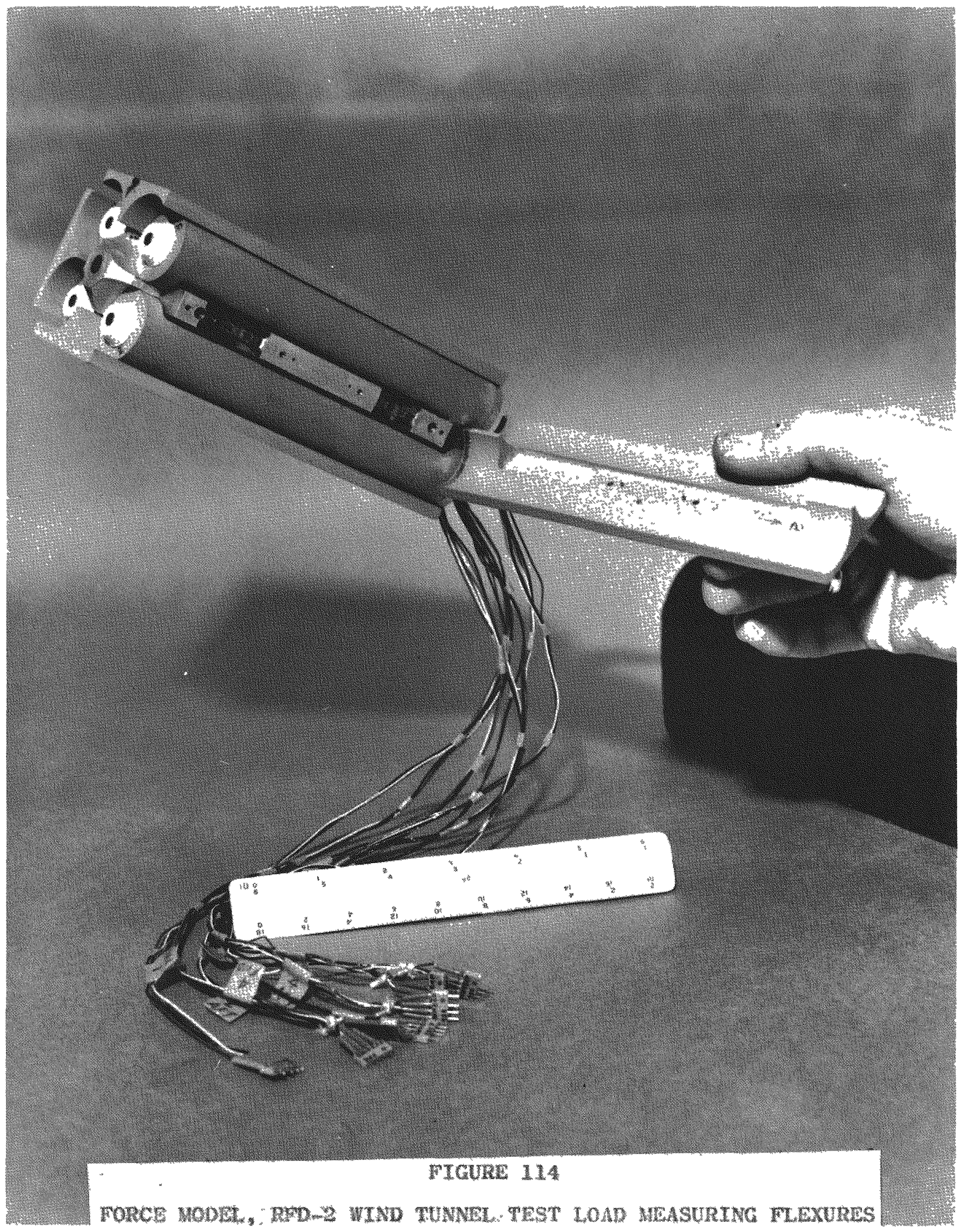




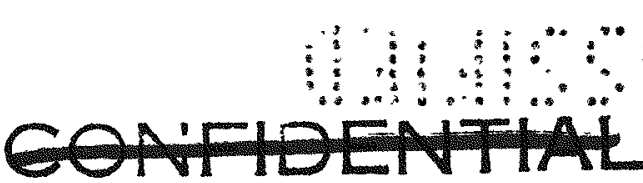

Initially, eight runs were made on the force model, four with the flush configuration and four with the recessed configuration. However, it was learned while evaluating the data that the four recessed configuration runs resulted in forces greater than the capacity of the model's load measuring flexures. Therefore, four additional runs were made on the recessed configuration with stronger flexures. The force model was installed in the tunnel on a down stream sting which could be pivoted for various angles of attack. Four angles of attack were studied; $0^{\circ}$, $10^{\circ}, 20^{\circ}$ and $30^{\circ}$.

\section{DATA AND RESULTS}

In measuring the aerodynamic characteristics on the force model, all normal forces were considered positive if acting away from the body. No negative forces were experienced in this test; however, forces acting on the bottom surface of the model approached zero at an angle of attack of $30^{\circ}$ and the center of pressure approached the forward end of the model assembly.

The average value of environmental conditions were as follows:

$$
\begin{aligned}
& \text { Altitute } 235,000 \mathrm{ft} . \\
& \text { Mach No. } 19.31 \\
& \text { Dynamic pressure } 0.176 \mathrm{psi}
\end{aligned}
$$

The results are shown in Figure 115 which are plots of normal force coefficient and center of pressure as a function of angle of attack. A non-dimensional parameter is presented rather than the raw force to permit selection of any flight regime. 
FIGURE 115

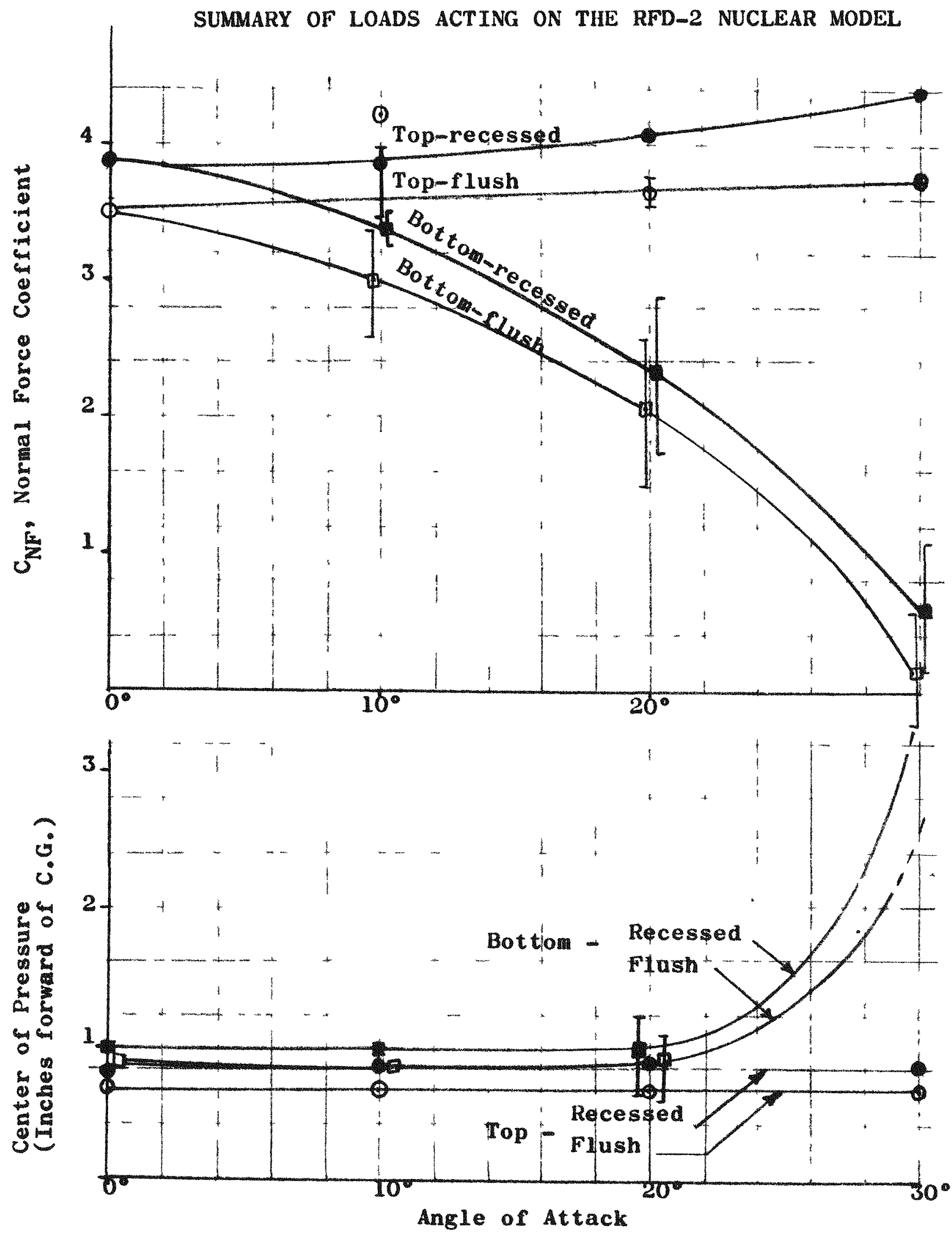

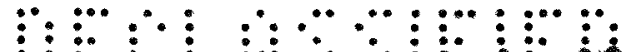


The coefficient of normal forces is defined as:

$$
C_{\mathrm{NF}}=\frac{F_{N}}{16 \mathrm{qS}}
$$

where

$$
\begin{aligned}
& F_{N} \text { is the measured normal force (oz) } \\
& q \text { is the dynamic pressure (psi) } \\
& S \text { is the reference area, } S=1 \text { in }^{2}
\end{aligned}
$$

The center of pressure is defined as:

$$
\mathrm{X}_{\mathrm{CP}}=\mathrm{X}_{\mathrm{CG}}-\frac{\Sigma \mathrm{M}_{\mathrm{CG}}}{\mathrm{F}_{\mathrm{N}}}
$$

where

$$
\begin{aligned}
& \mathrm{X}_{\mathrm{CG}} \text { is the center of gravity (in) } \\
& \Sigma M_{\mathrm{CG}} \text { is the sumation of moments about the } \\
& \text { center of gravity (oz-in) } \\
& \mathrm{F}_{\mathrm{N}} \text { normal force (oz) }
\end{aligned}
$$

Figures 116 and 117 show a sequence of high speed photographs of the free flight model. This sequence represents approximately 70 milliseconds of time. It can be seen that the block separates cleanly in this short span of time. No segment interfers with any other as they leave the fuel capsules. From the force measurements it can be seen that the recessed model provides larger separating forces than the flush model. However, this does not mean that it is the better design as will be discussed later.

\section{DATA INTERPRETATION}

Figure 118 shows the flow regime and shock wave about the model at an angle of attack of $10^{\circ}$. As the angle of attack is increased, the shock wave attaches closer to the surface along the bottom side and the bottom front leading 

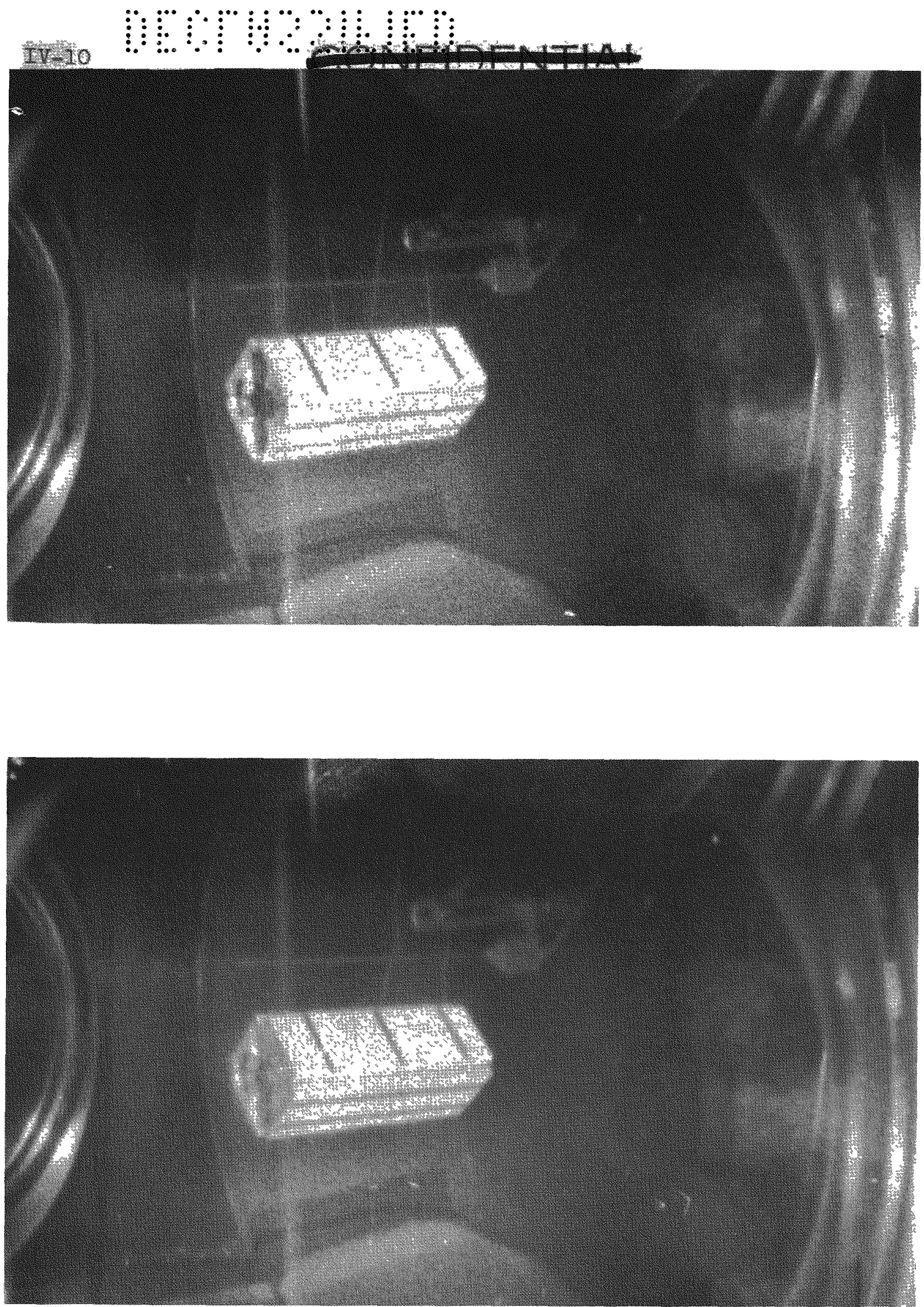

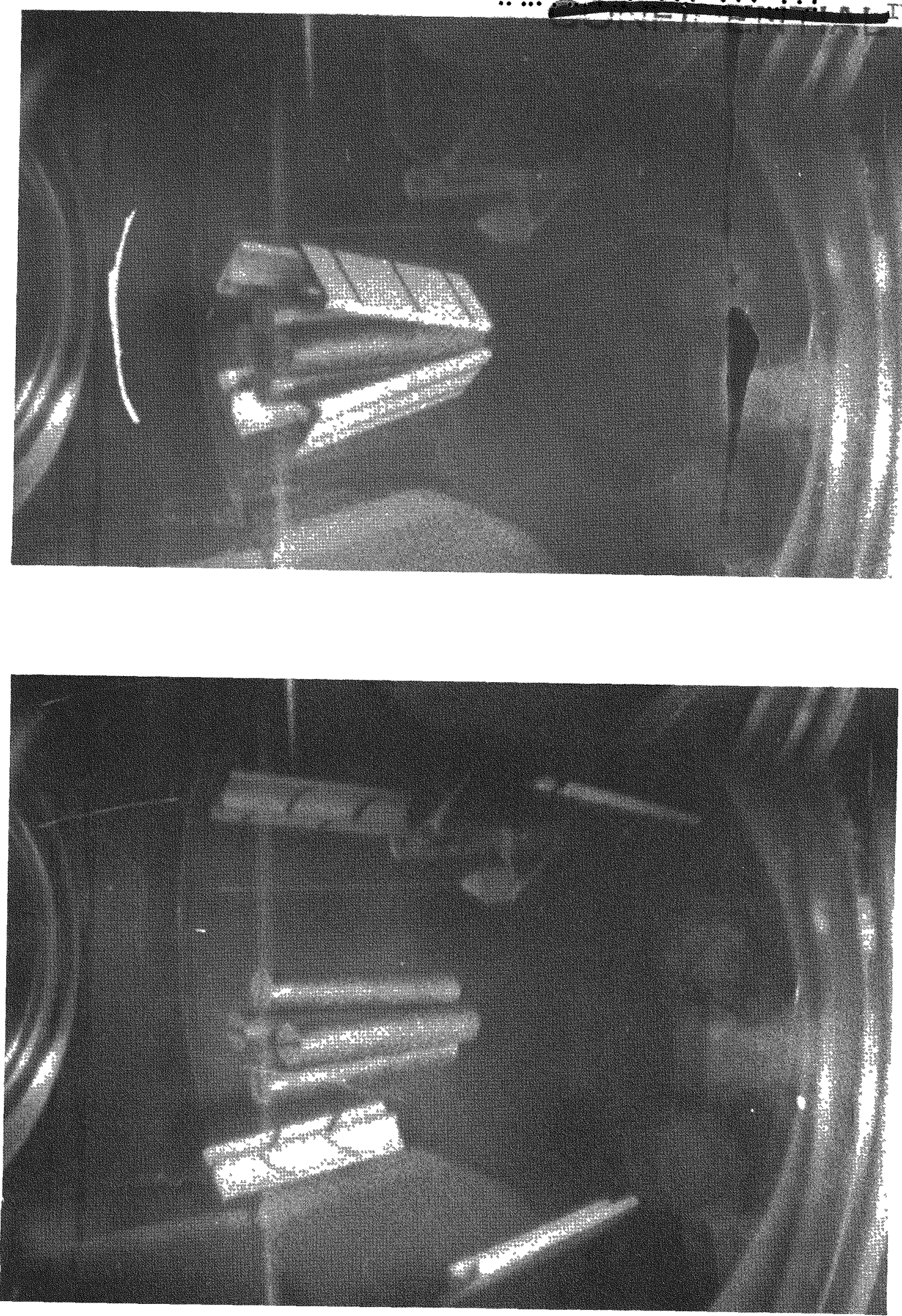

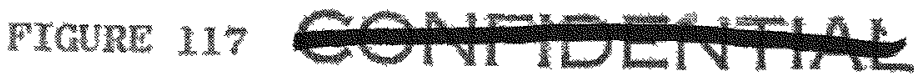

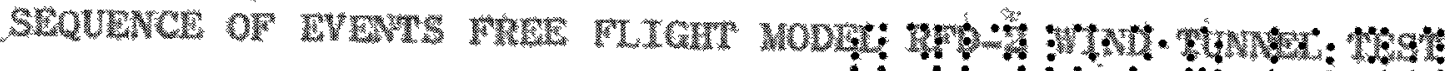

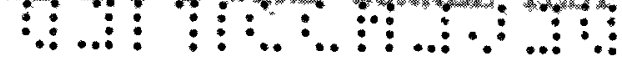


edge of the body, Figures 119 and 120. The effect on the front face would be to move the stagnation point towards the bottom edge. The closer the shock, the greater will be the thermal energy transfer, and the higher the temperature will become, resulting in hot spots at the front bottom-leading edge.

Tests were also conducted for a model with recessed fuel elements, i.e., with the $\mathrm{Al}_{2} \mathrm{O}_{3}$ coating removed and the capsule recessed into the heat accumulator block by a distance of 0.187 inches. The differences between the two tests for angles of attack of 10 and 20 degrees are not significant but a noticeable difference was detected for an $a=30^{\circ}$ orientation. Figure 121 shows the shock pattern over the surface of a recessed model at $\alpha=30^{\circ}$. If this pattern is compared with the pattern of Figure 120 it can be seen that the shock layer is much closer and more extended to the front bottom-leading surface. Therefore, the thermal energy transferred to this part of the body would be much higher than in the flush configuration. A similar evaluation can be made from the data collected on the force model, Figure 115. The forces on the bottom side of the model, which are directly proportional to the $C_{N F}$ coefficient, tend to approach zero and the center of pressure moves to the front face of the model as the angle of of attack increases.

At zero degree angle of attack, the normal force acting on the top and bottom sides will be acting away from the surfaces with equal magnitude, larger for the recessed model. As the angle of attack increases, the normal force on the top side remain relatively constant; however, the force on the bottom side decreases. Therefore, the pressure differential across the bottom side causes the 


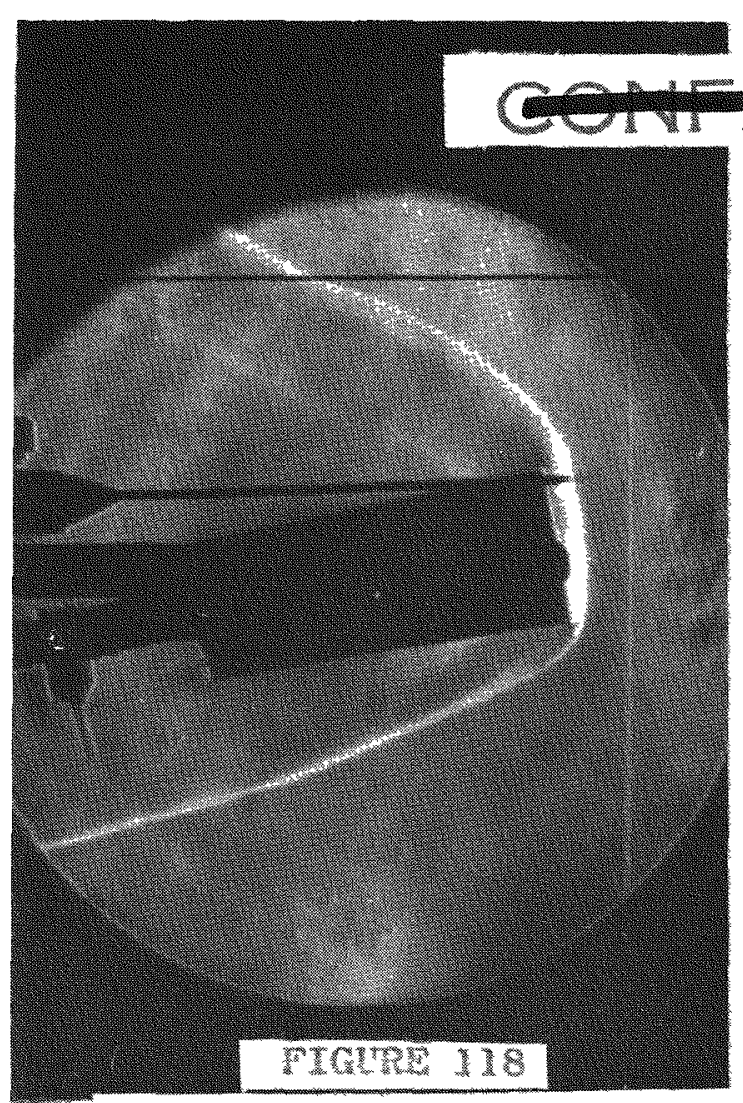

FONCE MODEL WLOW RECTME FUUSH CONFTCURARON

- 10\% MVOLE Or ATrack

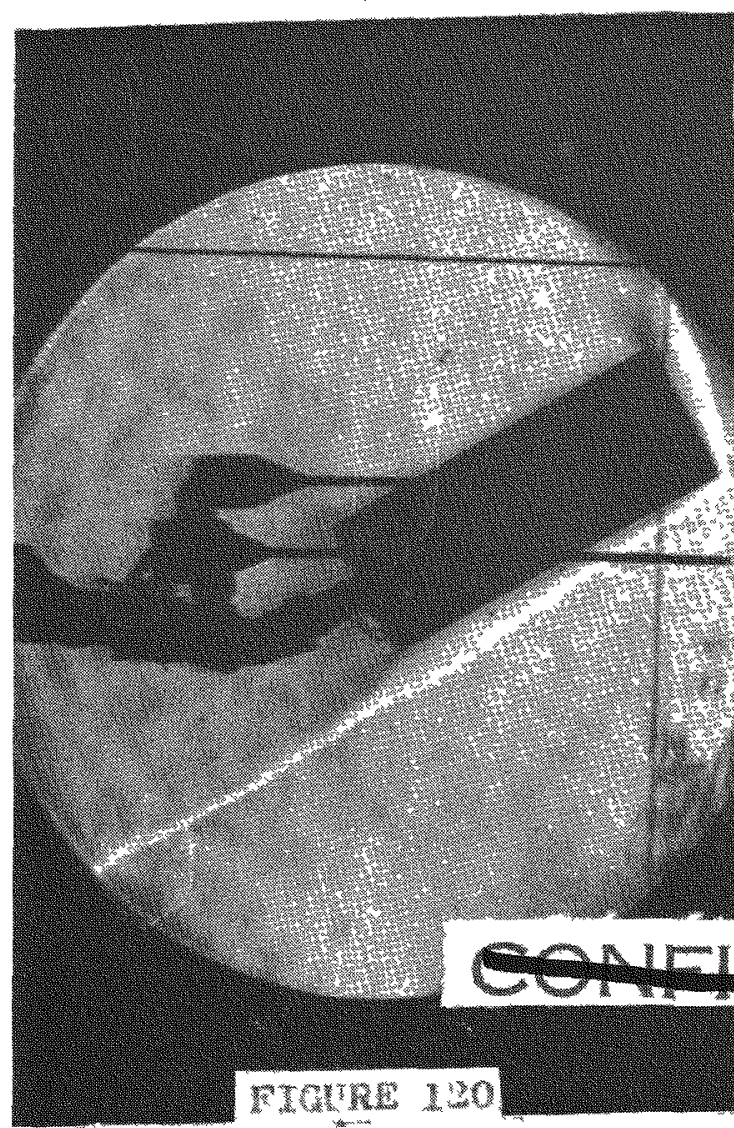

FORCE MODEL, FoW PWCTM WUSH CONFICURAT TON?

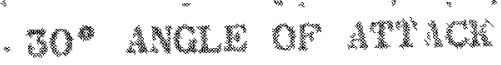

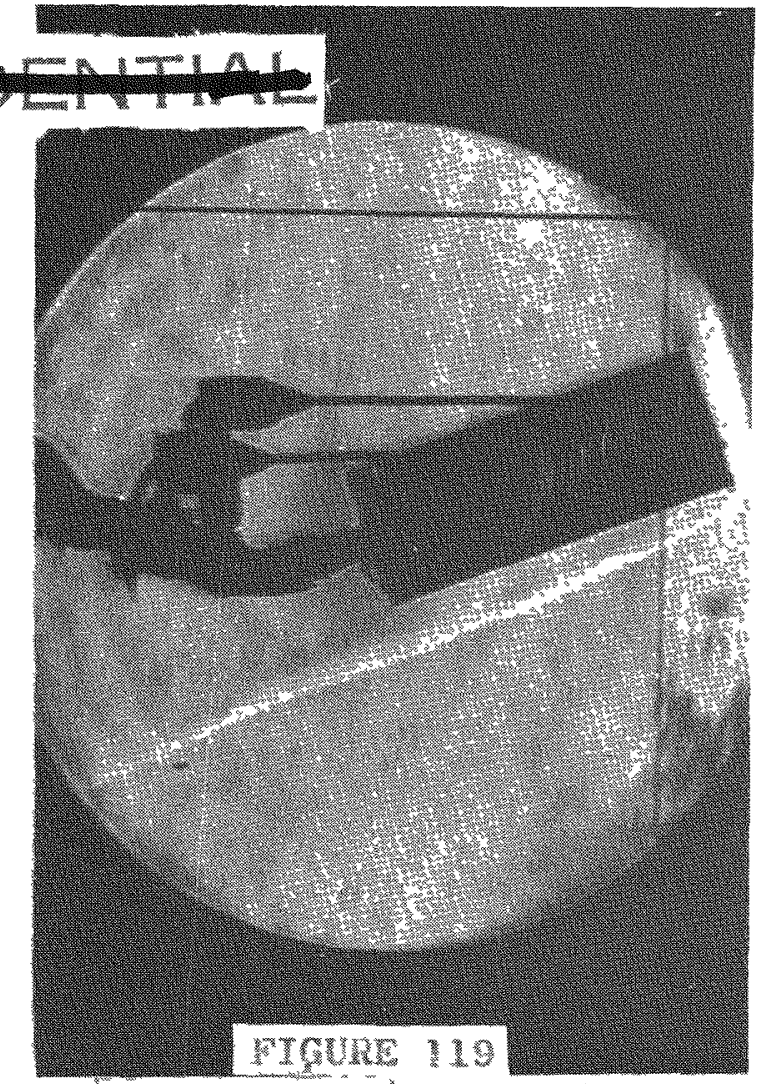

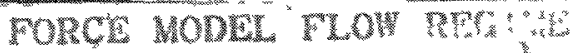

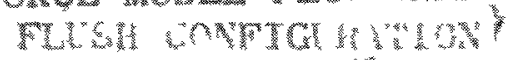

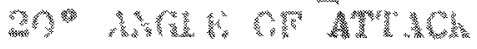

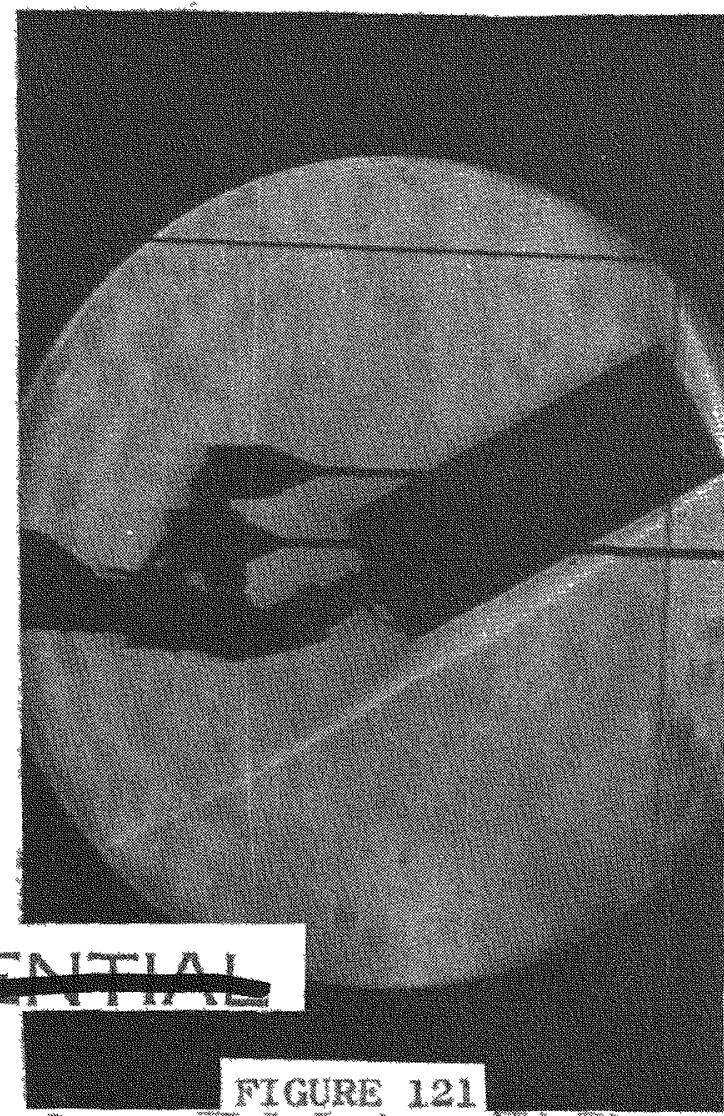

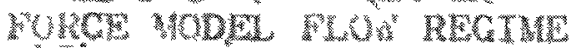

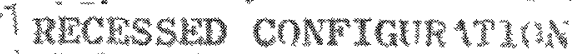

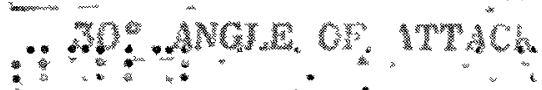




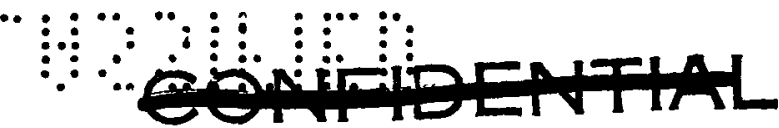

$4 \quad 2+1$

resultant force acting through the center of pressure to decrease. This decrease in pressure would tend to hold the bottom side intact in the flush configuration more so than in the recessed configuration. Hence, it can be summarized that there is no outstanding advantage in either design; therefore, from an aerodynamic consideration either configuration would be acceptable.

\section{E. CONCLUSIONS}

It can be concluded from this test that the heat accumulator block will separate from the fuel capsule when exposed to a re-entry environment. Further studies and tests will be performed to evaluate the separation of other materials from the heat accumulator block, which are present in the RFD-2 test model. 


\section{REFERENCES}

1. Schmidt, G., "Martin $200 \mathrm{KW}$ Plasma Jet Facility", ER 13213, Nov. 1963

2. Grindle, Shirley L., "Plasma Arc Tests of Thermoelectric Generator Metaliic Components", IT RO 53-3E3182, Plasmadyne, May 1963

3. Dobry, T. J., "SNAP 9A Radioisotope-Fueled Ganerator Final Safety Analysis For Transit Mission," MND-P2775-2 March 1963, SRD

4. Sandia Trajectory SNAP 000660, Sandia Corporation Sept 27, 1963

5. Chen, Shih-Kuan, and Allen, Stuart J., "Similarity Analysis for Transient Melting and Vaporizing Ablation", ARS Journal, October, 1962.

6. John, R. R. and Bade, W. L., "Testing of Reinforced Plastics Under Simulated Re-entry Conditions, Part I. Plasma Jet Calibration" AVCO Corporation, August $25,1959$.

7. Adams, Mac., C., "Recent Advances in Ablation", ARS Journal, Sept. 1959.

8. Thompson, H. W., "Advances in SpectroscopY", Interscience Publishers, Inc., (New York, 1961). 
APPENDIX A

Oxygen Availability Calculation

The method used to calculate available oxygen quantities considers only that oxygen which lies in the path of the re-entering specimen which, in essence, is a long, curved, imaginery "tube". Dimensions of this "tube" are found from typical flight trajectory programs and from specimen diameter.

For the purposes of this study, only the region from 240,000 feet to 100,000 feet altitude (region of significant heating) is of interest. To simplify procedures this region is divided into 10,000 feet increments. These increments are small enough that the re-entry path through each may be approximated as a straight line whose angle of deflection from the horizontal, $Y$, is the average reentry angle over that increment. The average atmospheric density over each increment, $P$, decreases exponentially according to the expression:

$$
\rho=\rho_{0} e^{-\beta h}
$$

where $\rho_{0}$ is sea level air density, $7.6064 \times 10^{-2}$ Ibs/ft $^{3}$; $B$ is an altitude-density variation function, $4.25 \times 10^{-5}$ ft $^{-1}$ between $10^{5}$ and $2.4 \times 10^{5}$ feet; and $h$ is altitude in feet.

The average air density for each altitude interval is estimated by the expression

$$
=\frac{0}{h_{2}^{-h_{1}}} \int_{h_{1}}^{h_{2}-\beta h_{d h}} \quad, h_{2}-h_{1}=10^{4} \text { feet }
$$




$$
=\frac{p_{0}}{10^{4}}\left(e^{-\beta h_{1}}-e^{-\frac{m}{h_{2}}}\right)
$$

Values of $Y, d$ and $\bar{p}$ as a function of altitude are shown on Table A-1.

To calculate the quantity of oxygen encountered by the specimen in each interval, the following equation is used:

$$
Q(1 \mathrm{bs})=0.21 \overline{\mathrm{p}} \alpha \mathrm{d}
$$

where 0.21 is the oxrgen concentration in air, $\bar{p}$ is the average air density in lbs/ft ${ }^{3}$ of each interval, $a$ is the specimen cross-sectional area in $\mathrm{ft}^{2}$, and $\mathrm{d}$ is the slant distance in feet (See Table A-1).

Summing these values, it is found that the total oxygen quantity available between 100,000 and 240,000 feet is 0.21176 pounds. 
TABLE A-I

OXIDATION CALCULATIONS

\begin{tabular}{lcc}
$\begin{array}{l}\text { Altitude } \\
\text { Increment } \\
\left(10^{5} \mathrm{ft}\right)\end{array}$ & $\begin{array}{l}\text { Average } \\
\text { Path Angle } \\
\gamma \text { (Degrees) }\end{array}$ & Sin $\gamma$ \\
\hline $2.4-2.3$ & -1.3 & 0.02269 \\
$2.3-2.2$ & -1.5 & 0.02618 \\
$2.2-2.1$ & -1.8 & 0.03141 \\
$2.1-2.0$ & -2.2 & 0.03839 \\
$2.0-1.9$ & -2.6 & 0.04536 \\
$1.9-1.8$ & -3.1 & 0.05408 \\
$1.8-1.7$ & -3.6 & 0.06279 \\
$1.7-1.6$ & -4.3 & 0.07498 \\
$1.6-1.5$ & -4.7 & 0.08194 \\
$1.5-1.4$ & -5.2 & 0.09063 \\
$1.4-1.3$ & -6.4 & 0.11147 \\
$1.3-1.2$ & -8.1 & 0.14090 \\
$1.2-1.1$ & -10.4 & 0.18052 \\
$1.1-1.0$ & -13.6 & 0.23514
\end{tabular}

Slant Distance

$\left(d=10^{4} / \operatorname{Sin} Y\right)$

$\left(10^{4} \mathrm{ft}\right)$

$$
\begin{aligned}
& 44.092 \\
& 38.197 \\
& 31.837 \\
& 26.048 \\
& 22.046 \\
& 18.491 \\
& 15.926 \\
& 13.337 \\
& 12.204 \\
& 11.034 \\
& 8.971 \\
& 7.097 \\
& 5.540 \\
& 4.253
\end{aligned}
$$

\section{COHFA -}

$A-3$

Quantity of Available
$(Q=0.21$
0

Average Air 3

$\left[\bar{p}=\frac{p 0}{10^{4}}\left(e^{-B h l}-e^{-\beta h_{2}}\right]\right.$

$3.40 \times 10^{-6}$

$5.59 \times 10^{-6}$

$8.36 \times 10^{-6}$

1. $25 \times 10^{-5}$

$1.89 \times 10^{-5}$

$2.98 \times 10^{-5}$

$4.58 \times 10^{-5}$

$6.84 \times 10^{-5}$

$1.07 \times 10^{-4}$

$1.60 \times 10^{-4}$

$2.50 \times 10^{-4}$

$3.74 \times 10^{-4}$

$5.85 \times 10^{-4}$

$8.75 \times 10^{-4}$
$171.6 \times 10^{-5}$

$244.5 \times 10^{-5}$

$304.8 \times 10^{-5}$

$372.8 \times 10^{-5}$

$477.1 \times 10^{-5}$

$630.9 \times 10^{-5}$

$835.2 \times 10^{-5}$

$104.45 \times 10^{-4}$

$149.5 \times 10^{-4}$

$202.1 \times 10-4$

$256.8 \times 10^{-4}$

$303.9 \times 10^{-4}$

$371.1 \times 10^{-4}$

$426.1 \times 10^{-4}$ 


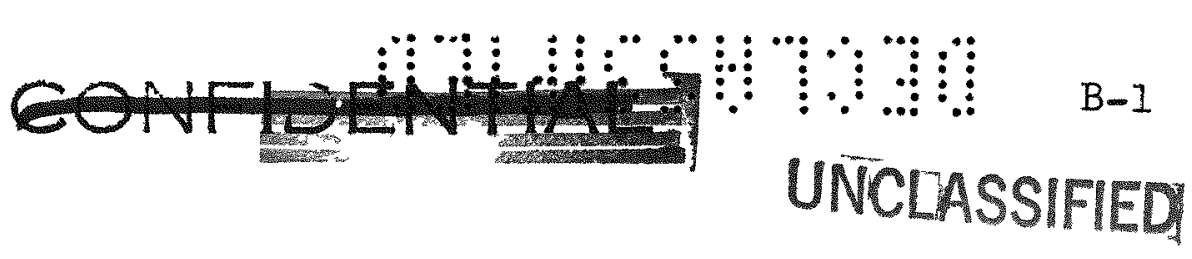

\section{APPENDIX B \\ Tantalum Metalographic Analysis}

Specimens Received: (1) a longitudinally bisected cylinder specimen in Nuclear Metallography Mount \#13496 with a companion counterpart in Mount \#13495, (2) a specimen prepared in like manner in Mount \#13354, (3) various odd pieces of tantalum cylinders unmounted.

General observations: The coating on the tantalum in Mount \#13496 varied from 44 to 60 mils in thickness and the coatings on the sides of the unmounted cylinders were not over ten mils thick. A white compound, apparently crystalline with some metal inclusions, was observed.

Techniques Employed: The portion of the Mount covering the coated-surface of the specimen was carefully ground away until the coating was exposed. The mount containing the exposed coating was mounted on the goniometer of the X-ray diffraction unit and a conventional 'strip-chart' diffraction pattern obtained. Successive portions of the surface were removed, until the base metal was exposed. Each time, a diffraction pattern was obtained. Also, emission spectroscopy studies were made of the coatings and nitrogen analyses were made to ascertain whether or not nitrides were present.

Findings: The heavy coatings on the ends of the cylinders had no metallic elemental constituents above trace level other than the major element present, tantalum, which was present as tantalum oxide. No nitride phase was formed. 
The coating consisted of a homogeneous phase of tantalum oxide, a high-temperature form designated as 'alpha' tantalum pentoxide $\left(\alpha-\mathrm{Ta}_{2} \mathrm{O}_{5}\right)$. This high temperature phase persisted from the surface down to the base. Alpha tantalum pentoxide structure was readily identified and we1l-ordered throughout the coating. No other oxide structure was identified.

The powdered-materials from the sides of the cylinders consisted of the same high-temperature alpha-form of tantalum pentoxide. One portion of this powdered material contained about 1000 ppm Mo.

Discussion: The high temperature form of tantalumpentoxide has been known for some years $(1,2)$. Reisman, et 21 , commented on the polymorphism of tantalum pentoxide ${ }^{(2)}$ in a study of the Group $V$ pentoxides. The melting point of $\alpha-\mathrm{Ta}_{2} \mathrm{O}_{5}$ was established at $187^{\circ} \pm 10^{\circ} \mathrm{C}$, fabout $100^{\circ}$ above the $\mathrm{B}^{-\mathrm{Ta}_{2} \mathrm{O}_{5}}\left(1785^{\circ} \pm 30^{\circ}\right)$.

Determination of the melting point of the beta form of the pentoxide was made possible only because the transformation reaction $\left(B \rightarrow \infty \sim 1360^{\circ}\right)$ is extremely $\mathrm{sluggish}$ even though characterized as a reversible reaction. This sluggishness is proven by the retention of the alpha phase in all of these plasma-jet test specimens. However, Reisman, et al, (2) have noted that air-quenched molten tantalum pentoxide yields the crystalline alpha phase.

It has been found that the oxidation of tantalum at 1 atm. takes place in the initial stage essentially by $a$ diffusion of oxygen through the metal lattice with the formation of suboxides postulated as $\mathrm{Ta}_{4} \mathrm{O}$ and $\mathrm{Ta}_{\mathrm{x}} \mathrm{O}_{\mathrm{y}}(3,4$, 5) This is followed by a transition to a faster, Iinear 


\section{- \\ UNCLASSIEIED}

oxidation with formation of $\mathrm{Ta}_{2} \mathrm{O}_{5}$. Optical examination of these coatings give support to this mode of oxidation.

A Russian group, Simanov, et al, (6) claims finding three modifications of $\mathrm{Ta}_{2} \mathrm{O}_{5}$ between $800^{\circ}$ and $1100^{\circ} \mathrm{C}$; a hexagonal form at $800^{\circ} \mathrm{C}$, a modified rhombic form existing up to $1100^{\circ} \mathrm{C}$, as we 11 as the known betaphase. They found all of these forms of $\mathrm{Ta}_{2} \mathrm{O}_{5}$ unstable in air up to $920^{\circ} \mathrm{C}$.

Hock and Mathus (7) could not form any of the lower oxides of tantalum by reacting the metal $\mathrm{Ta}$ and $\mathrm{Ta}_{2} \mathrm{O}_{5}$ between $1450^{\circ} \mathrm{C}$ and $1850^{\circ} \mathrm{C}$.

The plasma-jet specimens offer conclusive evidence of the formation, and retention on quenching, of only the $\mathrm{Ta}_{2} \mathrm{O}_{5}$ phase. Even at the boundary between the oxide and the base metal, no other phase was detected. 
References:

(1) Hahn, J. Amer. Chem. Soc. 73, 5091 (1951).

(2) Reisman et al, J. Amer. Chem. Soc. 78, 4514 (1956).

(3) Tidsskr. Kjena, Bergvesen, Met. 21, 196 (1961)

(4) Powell et al, hcta Met. 10, 149 (1962).

(5) Harvey and Wilman, Acta Cryst. 14, 1278 (1961).

(6) Simanov et al, Uestnik Moskov. Jniv. 9, No. 9 Ser. Fiz-Mat. i Estestives. Nauk No. 6, 109, (1954).

(7) Hock and Mathus, J. Amer. Chem. Soc. 45, 373 (1962). 